$\div$

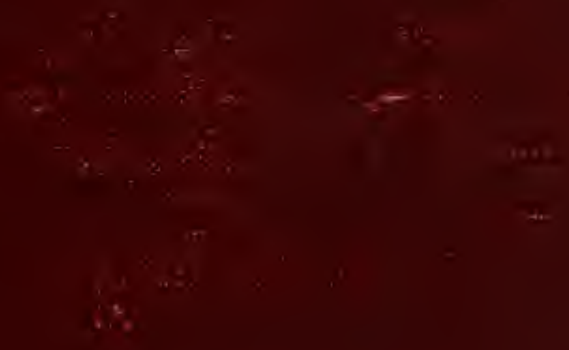



으르

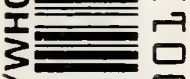

当紧

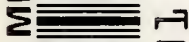

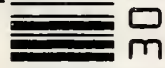

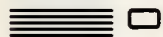

ए

単

 




BY THE SAME AUTHOR
ELEMENTARY ZOOLOGY
Pp. xV+492, 172 figs., 12mo, 1901,
\$1.20
FIRST LESSONS IN ZOOLOGY
Pp. x+363,257 figs., I2mo, 1903,
\$1.15
AMERICAN INSECTS
Pp. vii+671, 812 figs., 11 colored
plates, 8vo, 1905 (American Nature
Series, Group 1 ), \$5.00. Students'
edition, \$4.00
HENRY HOLT AND COMPANY
PUBLISHERS




\section{DARWINISM TO-DAY}

A DISCUSSION OF PRESENT-DAY SCIENTIFIC CRITICISM OF THE DARWINIAN SELECTION THEORIES, TOGETHER WITH A BRIEF ACCOUNT OF THE PRINCIPAL OTHER PROPOSED AUXILIARY AND ALTERNATIVE THEORIES OF SPECIES-FORMING

BY

\section{VERNON L. KELLOGG}

PROFESSOR IN LELAND STANFORD, IR., UNIVERSITY

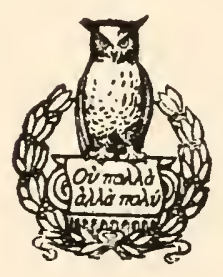

NEW YORK

HENRY HOLT AND COMPANY

1907 
COPYRIGHT, I907,

BY

HENRY HOLT AND COMPANY

Published August, 1907

THE QUINN \& BODEN CO. PRESS

RAHWAY, N. J. 


\section{PREFACE.}

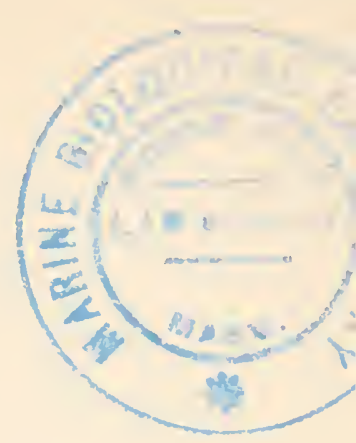

THIs book is written for the sake of presenting simply and concisely to students of biology and to general readers the present-day standing of Darwinism in biological science, and to outline for them the various auxiliary and alternative theories of species-forming which have been proposed to aid or to replace the selection theories.

Our actual knowledge of the factors and mechanism of organic evolution and our hypotheses and theories which serve to fill in the present gaps in this knowledge have been greatly added to and modified in the last few years. Much that the general reader includes in his conception of organic evolution, based on his reading of Darwin and Wallace and Spencer, has been materially modified and some of it proved untenable by modern investigation; while much which had no place in this earlier general understanding of evolutionary method and process may now be confidently added to it. The present time is one of unprecedented activity and fertility both in the discovery of facts and in attempts to perceive their significance in relation to the great problems of bionomics. Both destructive criticism of old, and synthesis of new hypotheses and theories, are being so energetically carried forward that the scientific layman and educated reader, if he stand but ever so little outside of the actual working ranks of biology, is likely to lose his orientation as to the trend of evolutionary advance. Precisely at the present moment is this modification of the general point of view and attitude of philosophical biologists unusually important and far-reaching in its relation to certain long-held general conceptions of biology and evolution. This modification of the general trend of evolutionary thought must also necessarily 
strongly affect our conceptions of the underlying principles of such correlated sciences as sociology, pedagogy, etc. It is, then, as a means of orientation in evolutionary matters for the general reader and for the unspecialised but interested student of science that this book is prepared.

That it may not be without some special usefulness to more advanced students and biological workers there are added, in appendices to the chapters, special notes (referred to in the text by small super-numbers) in which are given numerous exact references to general or special books or papers, and accounts, in more or less detail, of particular observations, experiments, or theoretical discussions, as well as references to extended bibliographic lists of the subjects under treatment. These notes will enable students, or others interested, to look up the original sources of our knowledge of the subjects of the various chapters, and to find more detailed general or special discussions of them than can be given in this book. These notes also enable the author to introduce into the book some details of his own observations and experiments touching various evolutionary subjects.

$$
\text { V. L. K. }
$$

Stanford University, June, 1907. 


\title{
CONTENTS.
}

\author{
CHAPTER I.
}

INTRODUCTORY: THE "DEATH-BED OF DARWINISM"

Modern activity in biologic study, r. Darwinism not synonymous with evolution, 3. Present-day anti-Darwinism, 4. Intemperate anti-Darwinism, 6. Outline of this book, 7 .

Appendix: Dennert's intemperate attack on Darwinism, 7. An anti-evolution university biologist, 8. Friedmann's theory to replace evolution with divergence, 8.

CHAPTER II.

DARIVINISM AND EVOLUTION DEFINED AND DISTINGUISHED

Animal and plant kinds originate in one of three ways, 10. The theory of descent defined, II. The theory of descent given validity by Darwin's explanation of the cause of it, I2. Darwinism defined and analysed into its fundamental assumptions and facts, i3. Sources of scien. tific evidence for the theory of descent, 17. Relation of theology, philosophy, pedagogy, and sociology to the theory of descent, 20.

Appendix: Accounts of history of the descent theory, 22. Books giving the evidences for descent, 23. Discussions of the relation of descent and theology, 23. Discussions of the relations of biology and philosophy, 24 . Biology and sociology, 24.

CHAPTER III.

DARWINISM ATTACKED

The attack of the theologians, 25. The present-day attack of the scientific men, 25. Some of the principal objections to natural selection summarised, 30. Darwinian or fluctuating variations too small to serve as "handles" 
for natural selection, 36. Many specific differences are indifferent, $i$. $e$., not adaptive, 38 . The extinguishing of the extreme variations by interbreeding, 44 . The improbability of the occurrence of the right variations at the right time, 45. The difficulty of explaining the production by natural selection of specialisations useful only in highly complex condition, 49. The objection based on the overdevelopment of specialisations, 53. The objection based on insufficient time, 54. The objection that natural selection tends to preserve the type rather than the variants, and hence opposes change, 56 .

Appendix: Books and papers on variation, 57. Cases of marked variation in parthenogenetic animals, 58. Variation according to the law of probabilities, 59. Quetelet, the discoverer of variation according to the laws of chance, 6I. Example of trivial variations, 62. Nägeli's seven objections to species-forming by selection, 62. Wolff's attack on the selectionists' assumption of the appearance at the right time of the needed variation, 64. Example of non-correlated variability in bilaterally repeated organs, 65. Henslow's antagonism to selection as an explainer of floral correlations, 67. Wolff's objection to the necessary assumption of identical and coincident variation in repeated structures, as feathers, scales, etc., 67. Example of mal-adaption in the egg-laying habit of Phryganidia californica, 68-Pieper's antagonism to the selection explanation of colour and pattern in insects, 69 .

\section{CHAPTER IV.}

\section{DARWINISM ATTACKED (Continued)}

Objection to the exclusively linear or quantitative character of the fluctuating or Darwinian variations, 70. Galton's law of regression, 7I. Selection may produce evolution (continuous change) but not species (discontinuous series), 73. Pfeffer's objection based on the slowness of species transformation, 75. The difficulty of explaining the sterility of species by selection, 76 . Selection cannot explain extreme or complete degeneration of useless parts, 77. Objections to the assumed rigour of the struggle for existence and to the actuality of intra-specific or personal selection, 79. Indiscriminate extermination due to the fortune of position and time, 8o. The necessity of sexual 
selection, a discredited theory, for the support of the natural selection theory, 85. Natural selection rests on an unwarranted assumption of its homology with artificial selection, 86. Many biologists find natural selection unable to account for known biologic conditions, 89. Significance of the concessions of Darwinians, 90. Korschinsky's extreme anti-Darwinian doctrine, 9I. Delage's "true rôle of selection," 93. Morgan's rejection of natural selection as a species-forming factor, 93.

Appendix: Galton's statement of the law of regression, 97. Wolff's criticism of panmixia, 98. Example of ineffective panmixia, Ioo. Example of progressivedegeneration inexplicable by natural selection, ıo. Wolff's discussion of the selection coefficient, Ior. Example of non-selection of trivial differences, I03. References to books and papers on plant breeding, I05.

\section{CHAPTER $V$.}

DARWINISM ATTACKED (Continued): THE THEORY OF SEXUAL SELECTION

Secondary sexual differences or characters, 107. Classification of secondary sexual characters, I07. Useless and harmful characters not explicable by natural selection, IIo. Theory of sexual selection to account for them: the theory defined, III. Darwin's assumptions as basis of the theory of sexual selection, II2. Difficulties in the way of a general application of the theory, II3. The theory applicable only to species in which males are more numerous than females, II3. The passivity of females, II4. Males of species in which no real pairing occurs also show striking secondary sexual characters, II4. Necessity of assuming unproved æsthetic development among lower animals, II4. Few recorded cases of observed choosing by female, II5. Difficult to assume utility for many secondary sexual characters, II5. Stolzmann's case of the Andean humming-birds, Ir6. How explain the beginnings of secondary sexual characters, ir7. How explain ornamental characters appearing in both males and females, II8. Morgan's objections to sexual selection theory, ir8. Experimental evidence touching the theory is against it, I20. Mayer's experiments with Promethea and Porthetria moths, I2I. Douglass's and Dürigen's observations on 
lizards, 123. Substitutionary theories of the origin of secondary sexual characters, 124.

APpendix: References to books and papers discussing sexual selection, 125. Wolff's critical exposition of weaknesses in sexual selection, 126.

\section{CHAPTER VI.}

DARWINISM DEFENDED

Position of the defenders of Darwinism, r29. Reaction against the too speculative positions of Haeckel and Weismann, r30. "Haeckelismus," I 30. Weismannism, I3I. Struggle between Neo-Darwinians and Neo-Lamarckians, I33. Concessions of the Neo-Darwinians, I34. Answer to objection concerning the too slight character of fluctuating or Darwinian variations to serve as handles for natural selection, I38. Answer to the objection concerning the linear and quantitative character of Darwinian variation, I39. Answer to the objection that selection cannot produce many-branched descent, I42. Answer to the statement that selection can produce continuous change or evolution, but not species, 143. Answer to the objection concerning the production by selection of co-adaptive and highly complex specialisations, I44. Answer to the objection concerning the over-development of specialisations, I46. Discussion of the difficulty that natural selection has with structural degeneration, 146. The Darwinian answer to the expressions of doubt about the rigour of selection, 148. Answer to the objections to the sexual selection theory, 148 . Discussion of the objection to the derivation of evidence for natural selection from the facts of artificial selection, I5o. Tayler's general defence, 153 .

Appendix: Weldon's experiments on Carcinus, 158. Tayler's explanation of degeneration by natural selection, 162. Plate's explanation of character fixity in domestic animals, 163 .

\section{CHAPTER VII.}

DARWINISM DEFENDED (Continued): PLATE'S CONCILIATORY DEFENCE

Plate, a fair-minded Darwinian champion, I64. Answers to the objection based on the slight character and inutility of Darwinian variations, 165 . Many slight differences at 
first glance apparently indifferent in character found on more careful inspection to be of advantage, I66. Slight characters aided by co-related differences, 167 . The principle of the change of function, 168. Characters of indifferent valus under one condition of environment, suddenly made important by a change in life-conditions, I69. Organs of universal character which can become modified in various directions, 169. Lamarckian factors called to the aid of Darwinism, 170. Answers to the objection based on the improbability of the appearance of the right variations at the right time for the progressive perfecting or development of an organ, I7o. Selection directs itself according to variation, not variation according to any assumed needs of selection, I7I. Selection works with plural variations, not single ones, i72. The same selective value can often be attained through combinations of various peculiarities and the same effect reached by various means, 172. The element of chance not peculiar to the Darwinian explanation of co-adaptations, 175. Answers to the objection based on the assumed improbability that during the course of the development of a complex organ or whole body-part, or during the perfecting of a changing adaptation the numerous necessary adaptations will occur in such a successive series as to make possible any harmonious correlation of the various single variations, i76. Plate's reliance on the Lamarckian factor of the inheritance of characters acquired through use, disuse, and other functional stimuli, 178. The attainment of selective value by various means, 178. Weismann's theory of germinal selection unacceptable, I80. Weismann's principle of amphimixis of great importance, I8o. The necessity of concessions admitted I8I. The necessity of invoking allxiliary or aiding principles to support the natural selection theory, I82.

Appendix: Conn's discussion of selective value, $\mathbf{I} 82$. References to papers on correlation, I84. Cope's proof that natural selection cannot originate new characters, I85.

\section{CHAPTER VIII.}

OTHER THEORIES OF SPECIES-FORMING: THEORIES AUXILIARY TO SELECTION · ·

The presentation of theories to aid the selection theories or others to replace them really a continuation of the 
defence of, and attack on, Darwinism, I87. The Weismannian theories, I88. Panmixia, I90. The theory of germinal selection, I93. The physical and chemical structure of protoplasm, I94. Objections to the theory of germinal selection, 200. Roux's theory of intra-selection, or the battle of the parts, 20I. Objections to Roux's theory, 203. The theory of organic selection, or orthoplasy, 268 .

Appendx: List of Weismann's evolution papers, 212. Theories of ultimate protoplasmic structure, 214. Encasement theory, 2I5. Micromeric theories, 2I5. Buffon's theory, 2I6. Spencer's theory, 2I7. Darwin's theory, 2 I8. Nägeli's theory, 2I9. De Vries's theory, 220. Hatschek's theory, 222. Delage's criticisms, 224. Le Dantec's criticisms, 224. Verworn's biogen hypothesis, 225. Delage's machine theory, 225. Le Dantec's theory of chemism, 225. Neo-vitalism, 226. Morgan's criticism of Weismann's method of argument, 229. References to discussions of orthoplasy, 229.

\section{CHAPTER IX.}

OTHER THEORIES OF SPECIES-FORMING (Continued): 'THEORIES AUXILIARY TO SELECTION (Continued)

Isolation theories, 232. Wagner's "Separations-theorie," 234. Jordan's upholding of the importance in speciesforming of geographic isolation, 237. Biologic and sexual isolation, or physiological selection, 243. Gulick's work and conclusions, 249 .

Appendix: References to discussions of isolation, 253. Haacke's summary of Wagner's theory, 253. Grinnell's studies of geographic differences in the chickadee, 255. Further references to discussions of isolation, $26 \mathbf{r}$.

\section{CHAPTER $X$.}

OTHER THEORIES OF SPECIES-FORMING (Contimued): THEORIES ALTERNATIVE TO SELECTION

Three general groups of theories proposed to replace the selection theories as explanations of species-forming and evolution, 262. The Lamarckian theory, 262. Objections to the Lamarckian factors, especially that of the inheritance 
of acquired characters, 266. Great use could be made of the Lamarckian factors in explaining evolution phenomena if these factors could be given validity, 27r. Orthogenesis and determinate variation, pointing toward orthogenesis, 271. Nägeli's theory of orthogenesis, 277. Eimer's orthogenetic theory, 282. Cope's theory of bathmism and kinetogenesis, 285 . Jaeckel's theory of metakinesis, 289.

Appendix: References to Lamarck's writings, 290. BrownSéquard's experiments on guinea pigs, 290. Hyatt's studies of Planorbis, 295. Fischer's experiments with butterflies, 296. Experiments with silkworms,298. References to books and papers on inheritance of acquired characters, 305. Redfield's position, 305. Montgomery's explanation of inheritance of variation, 306. Scientific aspects of Burbank's work, 3 ro. Orthogenetic variation in palæontology, 3rg. A case of apparent determinate variation, 319. Pfeffer's theory of orthogenesis, 320. Eimer's tlieory of orthogenesis, 32I. Apparent determinate evolution, 322. Snodgrass's observances on bills of Galapagos birds, 323. Cope's belief in orthogenetic evolution, 323. Whitman's belief in determinate variation, 325 . Cunningham and orthogenesis, 326.

\section{CHAPTER XI.}

OTHER THEORIES OF SPECIES-FORMING (Contimued): THEORIES ALTERNATIVE TO SELEC-

Heterogenesis or the mutations theory, 327. Formulations of heterogenesis theories by von Kölliker, Dall, Galton, and Emery, 330. Korschinsky's heterogenesis theory, 333. De Vries's mutations theory, 337. Present status of de Vries's theory, 348. Alternative theories to explain secondary sexual characters, 352 .

Appendix: Mendel and his work, 356. References to recent work on Mendelism, 357. Darwin's examples of race origin from sports, 357 . A recent example of race origin from a sport in cattle, 353. Galton's discussion of specific stability, 360. References to discussions by de Vries of species-forming, 362 . American opinions of the mutations theory, 362. Davenport's example of species origin by slight continuous change, 367 . Merriam's criticism of the mutations theory, 367 . Plate's criticism of the 
mutations theory, 368. References to theories explaining secondary sexual characters, 373 .

\section{CHAPTER XII.}

DARWINISM'S PRESENT STANDING

Natural selection the final control in evolution, but not 374 a sufficient explanation of species-forming, 374. Weaknesses of the substitutionary theories, 375. The unknown factors of evolution, 377. Prime needs of evolution study: first, the intensive study, statistical and experimental, of variability, 378. Second, the means of cumulating variability along definite lines, 379. Third, the investigation of adaptation, 380. A suggested argument for a belief in the transference of ontogenic changes into phylogeny, 382. A suggested automatic causal factor of variability, purposive but not purposeful, 384. Our present ignorance and the call to work, 387 .

Appendix: Wigand's criticism of the selection theories, 387. Lankester's upholding of Darwinism, 389. De Vries's discussion of species-forming by selection, 389. Delage's estimate of selection, 390. Osborn's championship of the unknown factors of evolution, 39r. Klebs's conclusions from experiments on plants, 392. Friedländer's discussion of adaptation, 392. Loeb's attitude toward the problem of species-forming, 393 . 
DARWINISM TO-DAY 



\title{
DARWINISM TO-DAY.
}

\author{
CHAPTER I. \\ INTRODUCTORY : THE "DEATH-BED OF \\ DARIVINISMI."
}

"Vour Sterbelager des Dariwinisues!" This is the title of a recent pamphlet ${ }^{1}$ lying before me. But ever since there has been Darwinism there have been occasional deathbeds of Darwinism on title pages of pamphlets, addresses, and sermons. Nuch more worth consideration than any clerical pamphlets or dissertations, under this title, by frischgcbackcncn German doctors of philosophy-the title alone proving prejudice or lack of judgment or of knowledgeare the numerous books and papers which, with less sensational headlines but infinitely more important contents, are appearing now in such numbers and from such a variety of reputable sources as to reveal the existence among biologists and philosophers of a widespread belief in the marked weakening, at least, if not serious indisposition, of Darwinism. A few of these books and papers from scientific sources even suggest that their writers see shadows of a death-bed.

The present extraordinary activity in biology is twophased; there is going on a most careful re-examination or Modern actir- scrutiny of the theories connected with organic ity in biologic evolution, resulting in much destructive critissudy.

cism of certain long-cherished and widely held beliefs, and at the same time there are being developed and almost feverishly driven forward certain fascinating and fundamentally important new lines, employing new methods, 
of biological investigation. Conspicuous among these new kinds of work are the statistical or quantitative study of variations and that most alluring work variously called developmental mechanics, experimental morphology, experimental physiology of development, or, most suitably of all because most comprehensively, experimental biology. ${ }^{2}$ This work includes the controlled modification of conditions attending development and behaviour, and the pedigreed breeding of pure and hybrid generations. Now this combination of destructive critical activity and active constructive experimental investigation has plainly resulted, or is resulting, in the distinct weakening or modifying of certain familiar and long-entrenched theories concerning the causative factors and the mechanism of organic evolution. Most conspicuous among these theories now in the white light of scientific scrutiny are those established by Darwin, and known, collectively, to biologists, as Darwinism.

To too many general readers Darwinism is synonymous with organic evolution or the theory of descent. The word is not to be so used or considered. Darwinism,

What Darwinism is. primarily, is a most ingenious, most plausible, and, according to one's belief, most effective or most inadequate, causo-mechanical explanation of adaptation and species-transforming. It is that factor which, ever since its proposal by Darwin in 1859 , has been held by a majority of biologists to be the chief working agent in the descent, that is, the origin, of species. However worthy Darwin is of having his name applied directly to the great theory of descent-for it was only by Darwin's aid that this theory, conceived and more or less clearly announced by numerous pre-Darwinian naturalists and philosophers, came to general and nearly immediate acceptance-the fact is that the name Darwinism has been pretty consistently applied by biologists only to those theories practically original with Darwin which offer a mechanical explanation of the accepted fact of 
descent. Of these Darwinian theories the primary and allimportant one is that of natural selection. Included with this in Darwinism are the now nearly wholly discredited theories of sexual selection and of the pangenesis of gemmules. It may also be fairly said that the theory of the descent of man from the lower animals should be included in Darwinism. For Darwin was practically the first naturalist bold enough to admit the logical and obvious consequences of the general acceptance of the theory of descent, and to include man in the general chain of descending, or ascending, organisms. So that the popular notion that Darwinism is in some way the right word to apply to the doctrine that man has come from the monkeys is rather nearer right than wrong. But biologists do not recognise the descent of man as a special phase of Darwinism, but rather of the whole theory of descent, or organic evolution.

Darwinism, then, is not synonymous with organic evolution, nor with the theory of descent (which two phases are

\section{Darwinism} used by the biologist practically synonymously). not synonymous Therefore when one reads of the "death-bed of with evolution. Darwinism," it is not of the death-bed of organic evolution or of the theory of descent that one is reading. While many reputable biologists to-day strongly doubt the commonly reputed effectiveness of the Darwinian selection factors to explain descent-some, indeed, holding them to be of absolutely no species-forming value-practically no naturalists ${ }^{3}$ of position and recognised attainment doubt the theory of descent." Organic evolution, that is, the descent of species, is looked on by biologists to be as proved a part of their science as gravitation is in the science of physics or chemical affinity in that of chemistry. Doubts of Darwinism are not, then, doubts, of organic evolution. Darwinism might indeed be on its death-bed without shaking in any considerable degree the confidence of biologists and natural philosophers in the theory of descent. 
But the educated reader, the scientific layman, the thinker and worker in any line of sociologic, philosophic, or even

Present-day anti-Darwinism. theologic activity is bound to be disturbed and unsettled by rumours from the camp of professional biologists of any weakness or mortal illness of Darwinism. We have only just got ourselves and our conceptions of nature, of sociology and philosophy, well oriented and adjusted with regard to Darwinism. And for relentless hands now to come and clutch away our foundations is simply intolerable. Zum Teufel with these German professors! For it is precisely the German biologists who are most active in this undermining of the Darwinian theories. But there are others with them; Holland, Russia, Italy, France, and our own country all contribute their quota of disturbing questions and declarations of protest and revolt. The English seem mostly inclined to uphold the glory of their illustrious countryman. But there are rebels even there. Altogether it may be stated with full regard to facts that a major part of the current published output of general biological discussions, theoretical treatises, addresses, and brochures dealing with the great evolutionary problems, is distinctly anti-Darwinian in character. This major part of the public discussion of the status of evolution and its causes, its factors and mechanism, by working biologists and thinking natural philosophers, reveals a lack of belief in the effectiveness or capacity of the natural selection theory to serve as a sufficient causo-mechanical explanation of species-forming and evolution. Nor is this preponderance of anti-Darwinian expression in current biological literature to be wholly or even chiefly attributed to a dignified silence on the part of the believers in selection. Answers and defences have appeared and are appearing. But in practically all these defences two characteristics are to be noted, namely, a tendency to propose supporting hypotheses or theories, and a tendency to make certain 
distinct concessions to the beleaguering party. The fair. truth is that the Darwinian selection theories, considered with regard to their claimed capacity to be an independently sufficient mechanical explanation of descent, stand to-day seriously discredited in the biological world. On the other hand, it is also fair truth to say that no replacing hypothesis or theory of species-forming has been offered by the opponents of selection which has met with any general or even considerable acceptance by naturalists. Mutations seem to be too few and far between; for orthogenesis we can discover no satisfactory mechanism; and the same is true for the Lamarckian theories of modification by the cumulation, through inheritance, of acquired or ontogenic characters. Kurz und gut, we are immensely unsettled.

Now but little of this philosophic turmoil and wordy strife has found its way as yet into current American literature. Our bookshop windows offer no display, as in Germany, of volumes and pamphlets on the newer evolutionary study; our serious-minded quarterlies, if we have any, and our critical monthlies and weeklies contain no debates or discussions over "das Sterbelager des Darwinismus." Our popular magazines keep to the safe and pleasant task of telling sweetly of the joys of making Nature's acquaintance through field-glasses and the attuned ear. But just as certainly as the many material things "made in Germany" have" found their way to us so will come soon the echoes and phrases of the present intellectual activity in evolutionary affairs, an activity bound to continue as long as the new lines of biological investigation continue their amazing output of new facts to serve as the bases for new critical attacks on the old notions and for the upbuilding of new hypotheses. If now the first of these echoes to come across the water to us prove to be, as wholly likely, those from the more violent and louder debaters, they may lead to an undue dismay and panic on our part. Things are really in no such desper- 
ate way with Darwinism as the polemic vigour of the German and French anti-Darwinians leads them to suggest. Says one of them: "Darwinism now belongs to history,

Intemperato anti-Darwinism.

like that other curiosity of our century, the Hegelian philosophy; both are variations on the theme: how one manages to lead a whole generation by the nose." The same writer also speaks of "the softening of the brain of the Darwinians." Another one, ${ }^{6}$ in similarly relegating Darwinism to the past, takes much pleasure in explaining that "we [anti-Darwinians] are now standing by the death-bed of Darwinism, and making ready to send the friends of the patient a little money to insure a decent burial of the remains." No less intemperate and indecent is Wolff's " reference to the "episode of Darwinism" and his suggestion that our attitude toward Darwin should be "as if he had never existed." Such absurdity of expression might pass unnoticed in the mouth of a violent non-scientific debater-let us say an indignant theologian of Darwin's own days-but in the mouth of a biologist of recognised achievement, of thorough scientific training and unusually keen mind-for this expression came from just such a man-it can only be referred to as a deplorable example of those things that make the judicious to grieve. Such violence blunts or breaks one's own weapons.

While I have said that the coming across the water of the more vigorous anti-Darwinian utterances might cause some dismay and panic in the ranks of the educated readerreally unnecessary panic, as I hope to point out-it will doubtless occur to some of my readers to say that this fear of panic is unwarranted. If the first phrases to come are as injudicious and intemperate, hence as unconvincing, as those just cited, the whole anti-Darwinian movement will be discredited and given no attention. Which, I hasten to reply, will be as much of a mistake as panic would be. There is something very seriously to be heeded in the 
chorus of criticism and protest, and wholly to stop one's ears to these criticisms is to refuse enlightenment and to show prejudice. I have thought it, therefore, worth while to try to anticipate the coming of fragmentary Outline of this book. and disturbing extracts from the rapidly increasing mass of recent anti-Darwinian literature by presenting in this book a summary account not alone of these modern criticisms, but of the answers to them by the steadfast Darwinians, and of the concessions and supporting hypotheses which the supporters of both sides have been led to offer during the debates. I shall try to give a fair statement of the recent attacks on, and the defence and present scientific standing of, the familiar Darwinian theories, and to give also concise expositions, with some critical comment, of the more important new, or newly remodelled alternative and auxiliary theories of species-forming and descent, such as heterogenesis, orthogenesis, isolation, etc., and an estimate of their degree of acceptance by naturalists.

\section{APPENDIX.}

${ }^{1}$ Dennert, E., "Vom Sterbelager des Darwinismus," Stuttgart, 1903. An intemperate and unconvincing but interesting brief against Dennert's in- the Darwinian factors, i. e., the selection theories, in temperate attack evolution. Author fully accepts the theory of descent, on Darwinism. but in no degree the Darwinian causal explanation of this descent. "Was ich in diesen Berichten nachzuweisen suche, ist die Tatsache, dass der Darwinismus nunmehr bald der Vergangenheit, der Geschichte angehört, dass wir an seinem Sterbelager stehen und dass auch seine Freunde sich eben anschicken, ihm wenigstens noch ein anständiges Begräbnis zu sichern" (p. 4). The valuable thing about the paper is that it is largely given to a gathering together of the anti-Darwinian opinions and declarations of numerous, mostly well-known and reputably placed biologists. Some of these declarations are interpreted by Dr. Dennert in a way that would probably hardly be wholly acceptable to the declarers, but for the most part the anti-Darwinian beliefs of these biologists are uumistakably revealed by their own words. Among the biologists and biological philosophers thus agglomerated into the camp of 
anti-Darwinısm are Wigand, Haacke, von Sachs, Goette, Korschinsky, Haberlandt, Steinmann, Eimer, M. Wagner, von Kölliker, Nägeli, Kerner, F. von Wagner, Fleischmann, O. Schultze, O. Hertwig, and others. This list includes reputable botanists, zoologists, and palæontologists.

${ }^{2}$ For a recent account of such work, see Morgan, T. H., "Experimental Zoölogy," I907.

${ }^{3}$ A. Fleischmann, professor of zoology in the University of Erlangen, is the only biologist of recognised position, of whom I am

An anti-evolu- aware, who publicly declares a disbelief in the theory tion nniversity of descent. He seems to base his disbelief on the biologist.

fact that the phyletic (genealogic) series in numerous. animal groups are as yet unexplained. See his book, "Die Descendenztheorie," Leipzig, Igor. "Allein je mehr ich mich in die vermeintlichen Beweisgründe derselben [the theory of descent] vertiefte und durch Spezialuntersuchungen positive Anhaltspunkte für die Stammesverwandtschaft der Tiere zu gewinnen suchte, um so klarer stellte sich mir die Erkenntniss heraus, dass jene Theorie eben doch mehr nur ein bestrickender, Ergebnisse und Aufklärung vortäuschender Roman sei, als eine auf positiven Grundlagen aufgebaute Lehre." (From the preface of this book).

"A curious attempt to formulate a scientific theory explaining the conditions as we know them in the world of life, to replace the Friedmann's theory of descent, is contained in a recent small book theory to replace called "Die Konvergenz der Organismen" (I904), evolntion with by Hermann Friedmann. The author assumes that the divergence,

diversity of organisms is the primary condition, and that their similarity has been brought about through convergence, as opposed to the postulate of the theory of descent to the effect that diversity of life has grown out of primary identity or homogeneity. I quote (p. I2) as follows from Friedmann: "Diese Annahme, die in dem vorliegenden Buch vertreten wird, ist folgendermassen zu erläutern. Wir gehen von dem Hauptsatze aus, dass das Leben immer als ein bestimmter, unwandelbarer Speziescharakter auftritt. Die spezifisch verschiedenen Lebensformen erscheinen jedoch einander angenähert, bezw. annäherbar, durch drei (Teil-) prinzipien, von denen das Leben beherrscht wird: Das Prinzip, vermöge dessen spezifisch verschiedene Formen solche Übereinstimmungen aufweisen, die wir als primärgesetzliche betrachten, nennen wir das Prinzip der Homologie; als einen Ausfluss des Prinzips der Analogie bezeichnen wir diejenigen Übereinstimmungen, die unter dem Einflüsse gleichwirkender äusserer (mittelbar oder unmittelbar bewirkender oder selektiver) Bedingungen entstehen; und wir erkennen drittens die Macht und die Tragweite eines Prinzips der 
direkten Konvergenz, welches das Entstehen von Übereinstimmungen zwischen den Genossen einer Biosphäre aus psychischen Ursachen bewirkt. Die drei Prinzipien bilden die Gruıdlage der Konvergenztheorie."

${ }^{5}$ Driesch, H., Biolog. Centralb., v. I6, p. 355, I8g6.

'Dennert, E., "Vom Sterbelager des Darwinismus," p. 4, I903.

'Wolff, G., "Beiträge zur Kritik der Darwin'schen Lehre," p. 54, I 898 . 


\section{CHAPTER II.}

\section{DARWINISM AND EVOLUTION DEFINED AND DISTINGUISHED.}

OUR manuals of zoology and botany contain the names and descriptions of about 400,000 living species of animals and 200,000 living species of plants. There are

Possible modes of origin of diverse plant and animal forms. parts of the earth from which we have collected as yet only a few kinds of animals and plants, merely the larger, more conspicuous or more abundant kinds; there are no parts of the earth from which we are not constantly receiving reports of the discovery of "new" species-new, of course, simply in the sense that we have not known them before. It is wholly certain that the number of different species, that is, kinds, of living organisms must number millions; various guesses, ${ }^{,}$ all unimportant, have been made. Of the extinct species, those hosts of strange denizens of our changing earth in the ages gone, the number of recorded forms can at best be but the veriest fraction of the grand total of species that have actually existed. Now all these millions of kinds of animals and plants can have had an origin in some one of but three ways; they have come into existence spontaneously, they have been specially created by some supernatural power, or they have descended one from the other in many-branching series by gradual transformation. There is absolutely no scientific evidence for either of the first two ways; there is much scientific evidence for the last way. There is left for the scientific man, then, solely the last; that is, the method 
of descent. The theory of descent (with which phrase organic evolution may be practically held as a synonym) is, then, simply the declaration that the various

Theory of descent defined. living as well as the now extinct species of organisms are descended from one another and from common ancestors. It is the explanation of the origin of species accepted in the science of biology. (The natural question about the first species or the first several, if they appeared simultaneously, will receive attention later; the theory of descent explains the origin of kinds of life, not the origin of life.) If such a summary disposal of the theories of spontaneous generation and divine creation is too repugnant to my readers to meet with their toleration, then, as Delage has pertinently said in connection with a similar statement in his great tome on "Heredity," my book and such readers had better immediately part company; we do not speak the same language.

The theory of descent, long before it was fully set forth by Darwin in 1858 together with a definite and wholly

Pre-Darwinian recognition of descent. plausible causo-mechanical explanation of it, had been foreshadowed and even fairly explicitly formulated by various philosophical naturalists; among others, Goethe (I790) in Germany, Erasmus Darwin ( I794) (grandfather of Charles Darwin) in England, Lamarck (I809) very definitely in France, Chambers in the "Vestiges of the Natural History of Creation" (I844), and Wallace (I858) coincidently with Darwin himself had all recognised descent as the only possible scientific explanation of the origin of species and had offered explanations of the causal factors of this descent. Even in the far older writings ${ }^{2}$ of the Greeks, most conspicuously perhaps in the pages of Aristotle (350), may be found phrases and pages foreshadowing those of Lamarck, Wallace, and Darwin. But it was not until Darwin had backed up the formulation of the descent theory with that 
wonderful accumulation of illuminating and explaining facts, and with those always ingenious but ever candid and supremely honest tryings-on of the theory to the various. fact-bodies, that the Theory of Descent began

Theory of descent given validity by Darwin. to be spelled with capital letters in the biological creed. Nor was it merely good-fortune that led to the quick and wide acceptance of the theory of descent when proposed by Darwin, while the same theory when proposed twenty years earlier by Lamarck found practically only rejection. It was because to the old descent theory the new Darwinian theories were added. It was because of that explaining Darwinism, which to-day is being so rigorously re-examined as to its validity, that the theory of descent took its definite place as the dominant declaration in the biological credo.

This Darwinism of 1858 and 1859 consisted of the selection theories; the Darwinian pangenesis of gemmules theory was a product of ten years later. It was the first of the Darwinian concessions to scientific anti-Darwinism. That is, it was a supporting hypothesis erected to strengthen a foundation which was being weakened by the eneny's attacks. Curiously enough this first Darwinian concession was made not on behalf of a true Darwinian principle, but for the sake of a Lamarckian principle which Darwin harl thought necessary to include in his general conception of the transmission of variations. Even in the formulation of the true Darwinism, the selection theories, there must also be recognised the participation of other minds than that of Darwin. Malthus, who wrote, in 1826 , of the over-supply and the consequent struggle in the human population and undoubtedly added much to Darwin's confidence in his own conception of the prodigality of production and the necessary struggle for life throughout the world of organisms, and Wallace, who came to conclusions practically identical with Darwin's at practically the same time, are men whose names 
are ever to be associated with the theory of over-production, struggle, and selection.

Darwinism may be defined, then, as a certain rational, causo-mechanical (hence, non-teleologic) explanation of the

The Darwinian explanation of descent. facts are: ( origin of new species. The Darwinian explanation rests on certain observed facts, and certain inductions from these facts. The observed ratio of the individuals in every species, whatever the kind of reproduction which may be peculiar to each species, whether this be simple division, sporulation, budding, parthenogenesis, conjugation and subsequent division, or amphimixis (sexual reproduction); (2) the always apparent slight (to greater) variation in form and function existing among all individuals even though of the same generation or brood; and (3) the transmission, with these inevitable slight variations, by the parent to its offspring of a form and physiology essentially like the parental. The inferred (also partly observed) facts are: (I) a lack of room and food for all these new individuals produced by geometrical multiplication and consequently a competition (active or passive) among those individuals having any œcologic relations to one another, as, for example, among those occupying the same locality, or needing the same food, or needing each other as food; (2) the probable success in this competition of those individuals whose slight differences (variations) are of such a nature as to give them an advantage over their confrères, which results in saving their life, at least until they have produced offspring; and (3) the fact that these "saved" individuals will, by virtue of the already referred to action of heredity, hand down to the offspring their advantageous condition of structure and physiology (at least as the "mode" or most abundantly represented condition, among the offspring).

The competition among individuals and kinds (species) 
of organisms may fairly be called a struggle. This is obvious when it is active, as in actual personal Struggle and selection.

battling for a piece of food or in attempts to capture prey or to escape capture, and less obvious when it is passive, as in the endurance of stress of weather, hunger, thirst, and untoward conditions of any kind. The struggle is, or may be, for each individual threefold in nature: (I) an active struggle or competition with other individuals of its own kind for space in the habitat, sufficient share of the food, and opportunity to produce offspring in the way peculiar and common to its species; (2) an active or passive struggle or competition with the individuals of other species which may need the same space and food as itself, or may need it or its eggs or young for food, and (3) an active (or more usually passive) struggle with the physico-chemical external conditions of the world it lives in, as varying temperature and humidity, storms and floods, and natural catastrophes. of all sorts. For any individual or group of individuals any of these forms of struggle may be temporarily ameliorated, as is (I) the intra-specific struggle among the thousands of honey-bee individuals living together altruistically in one hive, or (2) the inter-specific struggle when two species live together symbiotically as the hermit crab ${ }^{\text {E Eupagurus }}$ and the sea-anemone Podocoryne, or (3) the struggle against untoward natural conditions as in special times or places of highly favourable climate, etc. Or for any individual or group of individuals all forms of the struggle may be coincidently active and severe. The resultant of these existing conditions is, according to Darwin and his followers, an inevitable natural selection of individuals and of species. Thousands must die where one or ten may live to maturity ( $i$. e., to the time of producing young). Which ten of the thousand shall live depends on the slight but sufficient advantage possessed by ten individuals in the complex struggle 
for existence due to the fortuitous possession of fortunate congenital differences (variations). The nine hundred and ninety with unfortunate congenital variations are extinguished in the struggle and with them the opportunity for the perpetuation (by transmission to the offspring) of their particular variations. There are thus left ten to reproduce their advantageous variations. The offspring of the ten of course will vary in their turn, but will vary around the new and already proved advantageous parental condition: among the thousand, say, offspring of the original saved ten the same limitations of space and food will again work to the killing off before maturity of nine hundred and ninety, leaving the ten best equipped to reproduce. This repeated and intensive selection leads to a slow but steady and certain modification through the successive generations. of the form and functions of the species; a modification always towards adaptation, towards fitness, towards a moulding of the body and its behaviour to safe conformity with external conditions. The exquisite adaptation of the parts and functions of the animal and plant as we see it every day to our infinite admiration and wonder has all come to exist through the purely mechanical, inevitable weeding out and selecting by Nature (by the environmental determining of what may and what may not live) through uncounted generations in unreckonable time. This is Darwin's causo-mechanical theory to explain the transformation of species and the infinite variety of adaptive modification. A rigorous automatic Natural Selection is the essential idea in Darwinism, at least in Darwinism as it is held by the present-day followers of Darwin.

What auxiliary and supporting factors Darwin considered possibly or certainly of some influence or effect in species-

Artificial selection. our more particular examination of the natural forming we may postpone reference to until selection theory in succeeding chapters of this book. Simi- 
larly we may postpone any immediate reference to the facts of Artificial Selection (so important in any account of Darwinism), that process, more or less familiar to us all, whereby the plant and animal breeders quickly and extensively modify the particular species with which they deal so as to produce, to order, as it were, manifold new kinds (races) of organisms. Despite the complexity of methods used in artificial selection, due to the combining of hybridisation, direct modification by varying nutrition, grafting, budding, etc., with selection, the basic and all-important essential is the selecting of a few individuals, namely, those which show the desired variations, to live long enough to produce offspring, and the killing out before maturity of the thousands of individuals that show unfortunate variations: (unfortunate, that is, from the breeder's point of view). In the gardens of that extraordinary plant-breeder, Luther Burbank, in California, great bonfires of discarded seedlings correspond to the succumbing of the thousands in field and forest in the natural struggle for existence, while tenderly cared for little rows of pots contain the fortunate few which have withstood the rigours of the artificial competition.

A part of Darwinism, which has already been named as such, is the theory of Sexual Selection; but the details of this, too, we may leave unexplained for the Sexual selection. moment in order not too much to trouble the reader and the author, whose aim just now is to define the essential thought or conception in Darwinism, and to distinguish between this essential Darwinism and the different and wholly independent theory of descent. Sexual selection is one of Darwin's supporting theories which has nearly gone quite by the board. It is based on a postulated particular and limited kind of natural selection, not involving determination between life and death, but a determination between going childless and leaving posterity, -which is, after all, the essential determination in general 
natural selection. But the assumed choice in the theory of sexual selection has a much less mechanical and automatically working basis, involves violent assumptions regarding the rsthetic development of birds, butterflies, and spiders, and as we shall later see was one of the first of Darwinian outworks to be sadly breached by attack.

I hope now to have pointed out clearly in the preceding paragraphs the real distinction between the theory of descent and the theory of natural selection Theory of de- (Darwinism). The bases, consisting of obscent and the theory of natural served facts and logical reasons, of the selecselection dis- tion theory, have been given; perhaps it were
tinguished.

well to state briefly the bases, or sources of the scientific evidence for the theory of descent. This evidence is derived from three chief sources; the study of the comparative anatomy and structural homologies of organisms, the study of the prehistoric animals and plants, that is, palæontology or historical geology, and the study of ontogeny, or embryology, that is, the development of individual animals and plants. The homologies or structural correspondence, in gross and in detail, which the study of animal and plant comparative anatomy reveals to exist in varying degrees among living and extinct kinds of organisms have but one possible scientific explanation : an explanation which serves at once to account for the existence of this correspondence and for its varying degrees. Evidences for This explanation is community of ancestry, the descent. blood-relationship of organisms, the theory of descent. Similarly the facts revealed by the study of palæontology are explicable wholly satisfactorily by the theory of descent and in no single definitive instance do they contradict it. Finally, the facts and conditions relating to the embryology or ontogeny of animals and plants are similarly wholly in consonance with the theory of descent, although the brilliant positive evidence for the theory which 
the first revealing of the phenomena of ontogeny led biologists to expect and even to anticipate has confessedly not been forthcoming in that overwhelming measure hoped for. The evidence is excellent and positive and there is much of it, but the proof that man is descended from a fish because he has gill-slits at one period in his individual development is not of the sort to rely on too confidently. The recapitulation theory of Fritz Müller and Haeckel is chiefly conspicuous now as a skeleton on which to hang innumerable exceptions. But the scientific evidence for descent which embryology offers is neither weak nor slight; it is only less overwhelming and all-sufficient than its too sanguine early friends and sponsors attributed to it.

The specific character of the evidence for the theory of descent derived from the three chief sources just mentioned cannot claim our attention here. Knowledge of it is certainly the attribute of all educated readers. If any one should desire to refresh his memory of it, he may readily do this by reading his Darwin, or Wallace, or Huxley, Haeckel, Spencer, Weismann, Romanes, Marshall, Cope, ${ }^{4}$ et al. What may for the moment detain tts, however, is a reference to the curiously nearly completely subjective character of the evidence for both the theory of descent and natural selection. Biology has been until now a science of observation; it is beginning to be one of observation plus experiment. The evidence for its principal theories might be expected to be thoroughly objective in character; to be of the nature of positive, observed, and perhaps experimentally proved, facts. How is it actually? Speaking by and large we only tell the general truth when we declare that no indubitable cases. of species-forming or transforming, that is, of descent, have been observed; and that no recognised case of natural selection really selecting has been observed. I hasten to repeat the names of the Ancon sheep, the Paraguay cattle, the Porto Santo rabbit, the Artemias of Schmankewitch, and 
the de Vriesian evening primroses to show that I know my list of classic possible exceptions to this denial of observed species-forming, and to refer to Weldon's broad-and narrow-fronted crabs as a case of what may be an observation of selection at work. But such a list, even if it could be extended to a score, or to a hundred, of cases, is ludicrous: as objective proof of that descent and selection, under whose domination the forming of millions of species is supposed to have occurred. The evidence for descent is of satisfying but purely logical character; the descent hypothesis explains completely all the phenomena of homology, of palæontological succession, of ontogeny, and of geographical distribution; that is, it explains all the observed facts touching the appearance in time and place on this earth of organisms and the facts of their likenesses and unlikenesses to each other, and this no other theory does. The evidence for the selection theory we shall refer to in detail in the succeeding chapters, so we may merely recall now that it also chiefly rests on the logical conclusion that under the observed fact of over-production, struggle is bound to occur; that under the observed fact of miscellaneous variation, those individuals most fortunate in their variations will win in the struggle; and, finally, that under the observed fact of heredity, the winners will transmit to their posterity their advantageous variations, all of which inter-acting facts and logically derived processes will be repeated over and over again, with the result of slow but constant modification of organic types, that is, formation of new species. In the light of this subjective character of the evidence for descent and selection, it is with unusual interest that one notes the swift development of experimental and statistical investigation in biology. Experiment and statistics are capable of mathematical treatment; biology may become an exact science instead of one solely of observation and induction. As with the conclusion of this chapter we are practically 
to conclude all reference to the theory of descent, which is to-day more than ever before an integral and unquestioned part of biological science, and to devote most of the rest of our discussion to the theory of natural selection, which is to-day being subjected to more searching scientific criticism than ever before since its proposal by Darwin, it will be well to distinguish, if we can, in the general influence that postDarwinian biology has had on associated sciences and disciplines, that particular influence which each of these two great theories has had. So that if our faith in either is to be shaken we may recognise what effects on our sociologic, pedagogic, and philosophic beliefs this particular weakening of the biologic basis may have.

The relation of theology "to biology is concerned almost wholly with the theory of descent. The slow and gradual forming of species including the particular one, Relation of man, and their genetic relationship, the allying theory of descent of man by blood with the lower animals-these philosophy, are the two biological conceptions (both included in the descent theory) which have been the chief points of attrition in the coming together of theology and biology. Darwinism specifically as such, that is, the selection principle, has had some special attention from theologians because of its substitution of a causo-mechanical for a teleological explanation of species-forming, and because it differs in its interpretation of the time necessary for peopling the globe with a variety of organic forms from the interpretation, or rather explicitly specific statement, of the first chapter of Genesis. But on the whole the Darwinian selection theories could be utterly done away with without making any appreciable change in the existing relation between theology and biology. Huxley said this to the theologian Darwinophobes many years ago.

And practically so with philosophy. ${ }^{\circ}$ It is the transformation principle, the principle of continuity, of monism 
in Nature that Evolution represents, that philosophy is concerned to consider. Not the actual how of the modification and transformism of animal and plant life.

In pedagogy it is also the theory of descent rather than the selection theory which has been drawn on for some rather remarkable developments in child-

Relation of study and instruction. Unfortunately it is extheory of descent actly on that weakest of the three foundation
to pedagogy. pillars of descent, namely, the science of embryology with its Müllerian-Haeckelian recapitulation theory or biogenetic law, that the child-study pedagogues have builded. The species recapitulates in the ontogeny (development) of each of its individuals the course or history of its phylogeny (descent or evolution). Hence the child corresponds in different periods of its development to the phyletic stages in the descent of man. As the child is fortunately well by its fish, dog, and monkey stages before it comes into the care of the pedagogue, he has to concern himself only with its safe progress through the various stages of prehistoric and barbarous man. Detect the precise phyletic stage, cave-man, stone-age man, hunter and roamer, pastoral man, agriculturalist, and treat with the little barbarian accordingly! What simplicity! Only one trouble here for the pedagogue; the recapitulation theory is mostly wrong; and what is right in it is mostly so covered up by the wrong part, that few biologists longer have any confidence in discovering the right. What then of our generalising friends, the pedagogues?

Finally in sociology, more particularly biological sociology. Here again, to my eyes, much biological sociology rests on two very insecure bases: (I) a too Relation of slight acquaintance with biology on the part

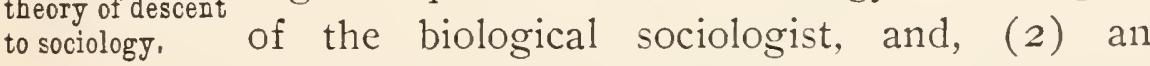
acceptance of, and confidence in, certain biological theories which are certainly unwarranted, and are not 
at all shared by the biologists themselves. Biological science contains much that is proved and certain; but also much that is nothing more than working hypothesis, provisional theory, and anticipatory generalisation. As the proved part is largely of the nature of facts of observation, isolated and unrelated, and the unproved part is composed of the large and sweeping generalisations, the plausible, provisional explanations, such as the various theories of heredity, of the results of struggle, of the development of mutual aid, etc., that is, is exactly the sort of material that the sociologist needs to weave into his biological foundations for the sociologic study of man, it is exactly this unproved part of biology that the searching sociologist carries home with him from his excursions into the biological field. The recapitulation theory looms up large and familiar in biological sociology; it is mostly discredited in biology. The inheritance of acquired characters serves as basis for much sociology; most biologists believe it impossible. The selection theories are gospel to some sociologists; they are the principal mont points in present-day biology. And so on. Biology is not yet come to that stage in its development where it can offer many solidly founded generalisations on which other sciences can build. The theory of descent is one such safe great generalisation; but perhaps Darwinism is not another. At least many scholars do not believe that it is.

\section{APPENDIX.}

${ }^{1}$ For the insects alone entomologists have estimated, on a basis of the numbers of new species being annually found and described, and on the basis of the degree to which the entomological exploration of the earth has been carried, that over two million species must be in present existence.

"See H. F. Osborn's "From the Greeks to Darwin" (I895) for a History of de- careful history of the unfolding of the descent idea; scent theory. see also Edgar Dacqué. "Der Descendenzgedanke und seine Geschichte." I903; also Carus, J. V., "Geschichte der Zoologie bis auf J. Müller und C. Darwin," I872; also Clodd, 
Edw.. "Pioneers of Evolution from Thales to Huxley," I897; and Quatrefages, A. de, “Les Émules de Darwin,” 2 vols., I894.

${ }^{3}$ Many of the hermit crabs (Paguridæ) which live in the discarded shells of gasteropod molluscs have some species of small colonial polyp, as Podocoryne, attached to and partly covering the shell. The polyp colony profits by being carried about and by obtaining bits of food when the crab has succeeded in catching prey and is tearing it to pieces with his claws, while the crab profits by the protection afforded it by the stinging threads and nettle cells of the polyp. Esig saw in the aquaria of the zoological station at Naples a small octopus which was trying to insert one of its tentacles into a shell to get the crab, quickly driven away by the many stinging threads with which it was caressed by the polyp colony seated on the outer surface of the shell. This symbiotic life between hermit crab and polyp goes so far with some species that the hermit crabs never rest until they have a polyp colony seated on their siell.

${ }^{4}$ Among more recent books stating the essential points in this evidence may be mentioned Conn's "Evolution of To-day." I889;

Books giving Wallace's "Darwinism," I89I; A. M. Marshall's the evidences for "Lectures on the Darwinian Theory," I894; Rodescent. manes's "Darwin and After Darwin." Vol. I, I896; Klaatsch's "Grundzüge der Lehre Darwins," I900; Metcalf's "Outline of the Theory of Organic Evolution," I904; Weismann's "Vorträge über Descendenztheorie," 2 vols., I902; Eng. trans. 2 vols., I904; Lotsy, J. P.. "Vorlesungen über Descendenztheorien, mit besonderer Berücksichtigung der botanischen Seite der Frage," 2 vols., Vol. I, I906; Jordan and Kellogg, "Evolution and Animal Life." I907.

"For an interesting discussion from the modern point of view of the relation between Darwinian biology and theology see Haechel,

Discassions of Ernst, "Der Monismus als Band zwischen Religion relation of de- und Wissenschaft." I893; also Vetter. Benjamin, scent and the- "Die moderne Weltanschauung und der Mensch," ology.

I903; also Wasmann, Erich, "Die moderne Biologie und die Entwicklungstheorie," I904. (Author is a Jesuit priest whose remarkable studies on ants and their messmates have made him well known to biologists. He accepts the theory of descent, with the exclusion of man from the evolution series.) See also Hutton. F. W., "The Lesson of Evolution," I902. In this book the author takes a strong stand for dualism, making the point that the theory of evolution has rescued philosophy from a rigidly monistic materialistic basis (a mind-in-all-matter theory), and has made necessary a dualistic theory (mind-and-matter theory) because of the necessity of postulating the beginning of life and a beginning of mind. The 
theory of evolution rescues religion from Pantheism, and puts it on a Theistic basis. "It is true, as Pantheists urge, that their only experience of mind is in connection with matter, but so far as we know mind is connected only with one kind of matter called protoplasm, which cannot possibly exist throughout the universe. Consequently mind must either be absent in large portions of matter or it must be associated with that matter in some way which quite transcends their experience. So that we have no more experience of mind universally distributed through matter than we have of mind distinct from matter. And the argument for Pantheism breaks down." See also Le Conte, Jos., "Evolution, its Nature, its Evidences and its Relation to Religious Thought," I89I.

${ }^{6}$ Of course many books and papers concerning the relation of biology to philosophy have been written. A good introduction to Discussions of the subject is Eugen Dreher's "Der Darwinismus und relation of biol- seine Stellung in der Philosophie," I877; see also Verogy and philoso- worn, Max, "Naturwissenschaft und Weltanschauung," phy. 1904; also Adickes, Erich, "Kant contra Haeckel," I90I; also Emil du Bois-Reymond's "Über die Grenzen des Naturerkennens," and "Die Sieben Welträthsel"; also Haeckel's "Die Welträthsel" (trans. in English as "The Riddle of the Universe"); see also Schurman, J. G., "The Ethical Import of Darwinism," I888; also Huxley, "Evolution and Ethics and Other Essays," I894; see also Reinke, J., "Einleitung in die Theoretische Biologie," Igor. The author sets out in this book the philosophic notions of Hartmann, Lotze, Wundt, Müller and others concerning the principles and laws of biology, and does this definitely enough to make his book a pretty good compend of philosophico-biology.

"See* Herbert Spencer's "Principles of Sociology"; also Lester Ward's "Biological Sociology"; also Benjamin Kidd's "Social EvoBiology and lution"; also Curt Michaelis, "Prinzipien der natür-
sociology, lichen und sozialen Entwicklungsgeschichte des Men-
schen," I904; also "Darwinismus und Sozialwissen-
schaft," I903; see also Schallmeyer, W., "Vererbung und Auslese
in Lebenslauf der Völker," Ig03.

* The books and papers referred to in notes 5,6 , and 7 are simply certain ones that have particularly interested the author. The lists of references make not the slightest pretence to guide the general reader interested in these special subjects. 


\section{CHAPTER III.}

\section{DARWINISM ATTACKED.}

AtTacks on Darwinism have been made, of course, ever since there was any Darwinism to attack. In those first days

(and months and years) after the "Origin of Early attacks Species" was published there were the liveliest on Darwinism. of times for Darwin and his supporters; or rather chiefly for the supporters. Darwin wisely kept aloof from the debates. But for the first band of followers with the indefatigable, the brilliant, and wholly competent Huxley at its head, there was no lack of opportunities for jousting. The issue was never doubtful; Huxley and his informed and equipped scientific companions against the scientifically ignorant, angry, incautious, and dogmatic Bishop Wilberforces had unfair odds. The victory came swiftly and brilliantly to the Darwinians. At this time there was little distinction made between Darwinism and Evolution. It was really a battle by the theologians against the theory of descent. And the theory of descent was, and is, invulnerable.

Since those warring days of the '6o's the theory of descent has been assailed no more, that is in any important or even interesting way. And the true Darwin-

Persistent sci- ism, the selection doctrine, has also been subentific criticism ject to no conspicuous and popularly recognised
of Darwinism. attack. The educated public accepted the results of the first battle as final, and it quietly began to rearrange its thought and to some degree its actual ways. 
of living in accordance with these newly discovered conditions of life. Nevertheless there has been from the day of the close of the great first battle to the present moment a steady and cumulating stream of scientific criticism ${ }^{1}$ of the Darwinian selection theories. In the last few years, it has, as already mentioned in the preface and introductory chapter of this book, reached such proportions, such strength and extent, as to begin to make itself apparent outside of strictly biological and naturo-philosophical circles. Such older biologists and natural philosophers as von Baer, von Kölliker, Virchow, Nägeli, Wigand, and Hartmann, and such others writing in the nineties and in the present century as von Sachs, Eimer, Delage, Haacke, Kassowitz, Cope, Haberlandt, Henslow, Goette, Wolff, Driesch, Packard, Morgan, Jaeckel, Steinmann, Korschinsky, and de Vries, are examples which show the distinctly ponderable character of the anti-Darwinian ranks. Perhaps these names mean little to the general reader; let me translate them into the professors of zoology, of botany, of palaontology, and of pathology, in the universities of Berlin, Paris, Vienna, Strassburg, Tübingen, Amsterdam, Columbia University, etc. Now without knowing the man personally, or even through his particular work, the general reader can safely attribute to men of such position a certain amount of scientific training, of proved capacity, and of special acquaintanceship with the subject of their discussion. One does not come to be a professor of biology in Berlin or Paris or Columbia solely by caprice of ninisters of education or boards of trustees; one has proved one's competency for the place. To working biologists the names-I have given, of course, only a selection, and one particularly made to show variety of interest (botany, zoology, palæontology, pathology) - mean even more than the positions. They are mostly associated with recognised scientific attainment and general intellectual capacity. 
Among the critics of the selection theories we must note two groups, differing in the character of their criticism Two groups of more in degree than in kind, perhaps, but still scientificat- importantly differing. One group denies in tackers.

toto any effectiveness or capacity for speciesforming on the part of natural selection, while the other group, a larger one, sees in natural selection an effective factor in directing or controlling the general course of descent, holding it to adaptive lines, but denies it outright any such Allmacht of species control as the more eager selectionists, the so-called neo-Darwinians or Weismannians, credit it with. This larger group of critics sees in natural selection an evolutionary factor capable of initiating nothing, dependent wholly for any effectiveness on some primary factor or factors controlling the origin and direction of variation, but wholly capable of extinguishing all unadapted, unfit lines of development, and, in this way, of exercising decisive final control over the general course of descent, $i$. $e$., organic evolution. Another classification of critics may be made on the basis of pure destructiveness on the one hand as opposed to destructiveness combined with constructiveness on the other. That is, some critics of selection, as Wolff, Pfeffer, Driesch, ct al., are content with doing their best to reveal the incapacity of Darwinism; others, on the contrary, come with certain more or less well-outlined substitutionary theories in their hands. Eimer with his theory of orthogenesis, and Korschinsky and de Vries with their theory of mutations, are examples of the latter class.

The general impression left on one after a considerable course of anti-Darwinian reading ranging all the way from the extreme attitude and the violence of DenStrength of
ttack and weak- nert, Fleischmann. Wolff, and Coe, to the ness in substitn- tempered and reserved criticism of Delage and tion.

de Vries, is that there is a very real and effective amount of destructive criticism for Darwinians to meet; and 
at the same time a curious paucity of satisfactory or at all convincing substitutionary theory offered by the antiDarwinians to replace that which they are attempting to dethrone. The situation illustrates admirably the varying worth of a few facts. A few stubborn facts of the wrong complexion are fatal things for a theory; they are immensely effective offensive weapons. But these same few facts make a pitiable showing when they are called on to support a theory of their own. It was exactly the greatest part of Darwin's greatness, it seems to me, that he launched his. theory only after making the most remarkable collection of facts yet gathered together in biological science by any one man. Testing his theory by applying to it successively fact after fact, group after group and category after category of facts, he convinced himself of the theory's consonance with all this vast array of observed biological actuality. Compare the grounding of any of the now offered replacing theories with the preparation and founding of Darwinism. In I864 von Kölliker," a great biologist, convinced of the incapacity of natural selection to do the work assigned it by its founders and friends, suggested a theory of the origin of species by considerable leaps; in I899, Korschinsky, ${ }^{3}$ on the basis of some few personal observations and the compiling of some others, definitely formulated a theory of speciesforming by sudden considerable variations, namely, mutations; in I90I and Igo3 appeared the two volumes of de Vries's "Die Mutationstheorie," in which are revealed the results of long years of careful personal observation, in truly Darwinian manner, directed toward the testing and better grounding of this mutationstheorie of species-origin. The results are: out of many plant species studied, a few show at certain times in the course of numerous generations. a behaviour in accordance with the demands of a theory of species-forming by sudden definitive modification; that is, species-forming by mutations. The mutations-theory 
thus launched is offered as a substitute for the natural selection theory obviously weakening under the fire of modern scientific criticism. But however effective de Vries's facts are in proving the possibility of the occurrence of other variations than those fortuitous ones occurring in continuous series from mean to opposite extremes which Darwin recognised as the basis of species-forming, and however effective they are in proving the actual production of three or six or ten species by mutation, and however effective in both these capacities they are as weapons of attack on the dominance of the Darwinian theory of species-making, how really inadequate are they to serve as the basis of a great all-answering theory explaining, in a causo-mechanical way, the facts of descent, or even the primary facts of general species-forming. And yet the first American book (from the pen of one of America's foremost biologists) to discuss the modern phase of unrest and dissatisfaction in evolutionary matters, practically accepts the mutationstheory as a substitute for the selection theory of speciesforming. It cannot be, it seems to me, that Professor Morgan is so satisfied with the mutations-theory, that he clutches it up, hardly definitely formed and cooled, from the de Vriesian moulds, but that he is, like many another presentday biologist, so profoundly dissatisfied with the natural selection theory. For my part it seems better to go back to the old and safe Ignoramus s standpoint.

But I have been led to anticipate my conclusions; let us make another beginning with the real undertaking of this chapter and get to the actual specifications of "Darwinism Attacked." We shall concentrate the attacks and attackers in this and the two following chapters; then include in the succeeding two the defence and the defenders, and in the next four chapters the various supporting and substitutionary theories offered by the friends and foes of Darwinism. Finally, in the last chapter we shall set out what we can 
discover, in the haze of the smoke of battle, of the actual present state of the besieged and besiegers.

Distinctly the most comprehensive, the fairest-minded review of gegen-und-fïr Darwinismus in recent literature is Plate's extension of his address, "Über die Bedeutung des Darwin'schen Selectionsprincips," made in Hamburg before the Deutsche Zoologische Gesellschaft in 1899. To this review, as published in 1903 after being extended and brought up to date, I beg to acknowledge a special indebtedness in my present attempt to get together the more important criticism, both adverse and defensive, of Darwin. I have, however, assiduously sought out (with the help of librarians and my indefatigable Leipzig book-dealer friend Bernh. Liebisch), and perused the original pourings-forth of criticism and vilification even to the reading of some matter written by certain Roman Catholic priests with a considerable amateur interest in natural history and a strong professional interest in anti-Darwinism! But Plate has been a guiding hand in this search for active attacks and defence.

The natural selection theory as an all-sufficient explanation of adaptation and species-forming has always had a weakness at its base; it depends absolutely, of course, Natural selec-
tion theory based on variation. has no influence whatever on the origin or control of these variations except in so far as it may determine what individuals shall be permitted to give birth to other individuals. Now one of the chief problems in biology is exactly that of the origin, the causes, and the primary control of these congenital variations. ${ }^{8}$ Three principal explanations, no one of them experimentally proved or even fairly tested as yet, have been given of this actually occurring congenital variation, viz., (I) that there exists in the germ-plasm an inherent tendency or capacity to vary so that there is inevitable variation in all individuals, 
produced from germ-plasm, this variation being wholly fortuitous and fluctuating according to some (the belief of Darwin and his followers), or, according to others, this variation following certain fixed or determinate lines (determinate variation, orthogenetic variation, etc.); (2) that amphimixis, $i$. e., bi-parental parentage, is the principal cause of variation, it seeming logical to presume that individuals produced from germ-cells derived from the fusion of germ-plasm coming from two individuals more or less unlike would differ slightly from either of the parental individuals; and (3) that congenital variation is due to the influence of the ever-varying environment of the germ-cell producing individuals. The objections to any one of these theories may be very pertinent, as when one says regarding the first that calling a thing "inherent" is not clearing up in any degree a phenomenon for which we are demanding a causo-mechanical explanation; or of the second that it has been proved ${ }^{7}$ that individuals produced parthenogenetically, that is, from an unmated mother, vary and in some cases vary even more than do other individuals of the same species produced by amphimixis; or of the third that as far as our study of the actual processes and mechanism of the production of germ-cells and of embryos has gone, we have found no apparent means whereby this influence of the ambient medium can be successfully impressed on the germ-plasm. But however pertinent the objections to the why of variation may be they do not in any way invalidate the fact that variations do continuously and inevitably occur in all individuals, and that while many of these variations are recognisably such as have been impressed on the individual duringits personal development as immediate results of varying temperature, amount or kind of food, degree of humidity, etc., to which it may be exposed in its young life, others. seem wholly inexplicable on a basis of varying inclividual environment and are certainly due to some antenatal infu- 
ence acting on the germ-plasm from which the embryo is derived.

Now the natural selection theory, in its Darwinian and neo-Darwinian form, presupposes fortuitously occurring congenital variations of practically infinite

Darwinian, or variety in all parts of all organisms. Actual tion according to observation shows that all parts of all organthe law of chance.

isms do vary and that they vary congenitally, that is, independently of any immediate influence during development exercised from without by environmental conditions, as well as in response to these environmental influences, and finally that in many cases this variation is fortuitous, that is, that it occurs according to the laws ${ }^{8}$ of chance. The industrious statistical study of variations, including the tabulation of the variation condition in long series of individuals of the same species or race and the mathematical formulation of this variation condition, have shown that in many specific cases, studied in numerous kinds of animal and plant forms, the character of the variation in any particular character may be truly represented (with close approximation) by the mathematical expression and curve which would exactly define the condition in which the variation would exist if it actually followed the law of error. It is these continuous series of slight variations, these variously called fluctuating, individual, or Darwinian variations, occurring in all organisms at all times and often following, in their occurrence, the laws of chance, on which Darwin's theory of species-forming by natural selection is based. But this same industrious statistical and quantitative study of variation, which has proved that some variations do occur regularly, fluctuating around a mean or mode, has shown, as well, that in many cases the variations distinctly tend to heap up on one side or the other of the mean, that is, that they tend to occur along certain lines or toward certain direc- 
tions rather than uniformly out in all directions. Also it is true, and this has of course been long known, that by no means all variations are so slight nor in Discontinnons such perfectly gradatory or continuous series
variation. as is true of the gradatory Darwinian variations. "Sports" have been known to breeders of plants and animals ever since plant and animal breeding began. Bateson has

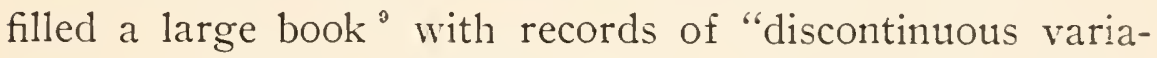
tions" in animals; variations, that is, of large size and not occurring as members of continuous gradatory series. So that biologists are acquainted with many cases of variation that seem to be of a kind, or to exhibit a tendency, to institute special directions of development, and thus not to be of the simple, non-initiating, inert character of the fortuitous, slight, fluctuating variations, among which natural selection is presumed to choose those that are to become the beginnings of new lines of modification and descent. Many biologists believe firmly that variations occur in many special cases, if not in most cases, only along certain special lines. Palæontologists believe, practically as a united body, that variation has followed fixed lines through the ages; that there has been no such unrestricted and utterly free play of variational vagary as the Darwinian natural selection theory presupposes.

Now it is at least obvious that natural selection is absolutely limited in its work to the material furnished by variation; so that if variation occurs in any cases

Determinate only along certain determinate lines selection variation as a species-forming factor. can do no more than make use of these lines. Indeed if variation can occur persistently along determinate lines natural selection's function in controlling evolution in such cases is limited to the police power of restricting or inhibiting further development along any one or more of these lines which are of a disadvantageous character, that is, a character which handicaps or 
destroys the efficiency of its members in the struggle for life. The question in many men's mouths to-day is, Why may not variation be the actual determinant factor in species-forming, in descent? It actually is, respond many biologists and palæontologists.

Even Darwin believed such determinate variation to occur, as is indicated by repeated statements in the "Origin of Species." In chapter iv he says (to refer to but a single one of these admissions): "It should not, however, be overlooked that certain rather strongly marked variations, which no one would rank as mere individual differences, frequently recur owing to a similar organisation being similarly acted on-of which fact numerous instances could be given with our domestic productions. In such cases, if the varying individual did not actually transmit to its offspring its newly acquired character, it would undoubtedly transmit to them, as long as the existing conditions remain the same, a still stronger tendency to vary in the same manner. There can also be little doubt that the tendency to vary in the same manner has often been so strong that all the individuals of the same species have been similarly modified without the aid of any form of selection. Or only a third, fifth, or tenth part of the individuals may have been thus affected, of which fact several instances could be given. Thus Graba estimates that about one-fifth of the guillemots in the Faroe Islands consist of a variety so well marked, that it was formerly ranked as a distinct species under the name of Uria lacrymans. In cases of this kind, if the variation were of a beneficial nature, the original form would soon be supplanted by the modified form, through the survival of the fittest."

This problem of the existence or non-existence of determinate variation is taken up in such detail in connection with the explanation and discussion of various auxiliary or alternative theories of species-forming in later chapters of this 
book that it need not detain us now. But to my mind it is one of the most important matters in connection with the

Does determinate variation exist? whole great problem of descent, that is, of evolution. It is the basic problem of evolution, for it is the problem of beginnings. Selection, isolation, and the like factors are conditions of species-forming; variation is a prerequisite, a sine qua non. True variation must have its causes, and these causes are to be determined before an actual causo-mechanical explanation of evolution can ever be found. But the determination of the relation of variation to speciesforming is certainly the first step now necessary in our search for the basic factors, the real first causes of species change.

But even in those cases where there may exist unrestricted indeterminate fluctuating variation in continuous series ac-

What does cording to the law of error, what is it that this fuctnating vari- variation really offers natural selection to ation offer selection as a basisfor work on? Remember what natural selection species-forming? is: the saving of one or ten by the actual killing of the thousand or ten thousand because in the struggle for existence the variations of the one or ten are of sufficient advantage to have a life-or-death-determining value. Now between any two successive individuals in a series arranged on a basis of the variations in any one character of any one organ or function, the difference is extremely slight. too slight, one is certain, to be, in most cases, of life or death value. But even if one's conception of the absolute intensity of the rigour of the personal struggle leads to a logical conception of an absolute advantage in any difference, however slight, in a favourable direction, it is wholly possible that for any other characteristic equally important in the struggle the two individuals may be in exactly reversed position, the one possessing the infinitesimal advantage in strength say, possessing an infinitesimal disadvantage in 
sharpness of claw or in agility. What of the chances for such a necessary coincidence in the one individual of favourable variations in all the ways necessary to create a real lifeor-death-determining advantage? The law of probabilities answers that much to the dismay of the Darwinian. But, again, why not compare the chances in the struggle of two individuals not standing side by side in a variational series, but at two extremes of the range; the difference here can be considerable, can be of positive advantage or disadvantage. Yes, but again comes the necessity of presupposing a coincidence of other advantages or at least of no coincidence of balancing advantages and disadvantages. But even more fatal is the condition that if an extreme variation in some one character could be of a life-preserving advantage, yet by the law of probabilities (and by the tale of actual observation) those individuals standing at the extremes of the range of variation are very, very few compared with those standing nearer the mean, or mode, of the series, and there would be almost a certainty of such an extreme-charactered survivor not finding a similar form with which to mate and thus insure perpetuation of the advantage, the mating of the individuals admittedly not depending on any necessary similarity in variation (unless the varying characteristics happen to be actually concerned with the mating act: see later discussion of biological isolation, chapter ix). Considerable variations, the only ones of apparent worth in a life-and-deatl struggle, are in such meagre disproportion to the less considerable that they are inevitably swamped, extinguished, in miscellaneous cross-mating.

Let us consider a little more in detail each of the various objections mentioned in the last few pages. Only the student

Insignificance of fluctuating variations. of systematic (classificatory) zoology or botany can realise how slight and insignificant are the various miscellaneous individual variations which make up that basis of ever-present, myriad-faced, 
fortuitous, fluctuating variability on which the whole great structure of the selection theory is based. Yet any one's common sense and his intuitive comprehension of what life-and-death value is in an animal's battle with another, with foreign enemies, or with inclement Nature, make this objection of "no handle for natural selection in miscellaneous slight variation" thoroughly appreciable. Polar bears are probably descended from brown; and their white fur coat is probably an advantageous adaptation in their life in the Arctic. But did the fortuitous appearance in his coat of a spot of white hairs as large as a dollar or a pancake give some ancient brown bear such an advantage in the struggle for existence as to make him or her the forerunner of a new and better-adapted sort of bear? The giraffe's long neck is very much worth while to it; it gets leaves from the higher branches unattainable by the shortnecked animals who find food in the same range. But did a millimetre or even an inch of extra neck appearing as individual variation in an ancestral short-necked giraffe kind give natural selection a handle with which to grind out a new species? The consideration of the usefulness of slight variations too often leads to an argument for their usefulness on the same grounds as sustain the belief that the hound will never catch the hare which goes one-half as fast as the dog. For each time the hound covers the given stretch that lies between him and the hare at any given moment the hare will be just one-half that distance in advance-and though the distance will get ever shorter and shorter the hare will ever be one-half the last distance ahead. So say the sophists. As a matter of fact the hound gets the hare.

Spencer's example of the femur of the whale is a striking illustration of the reality of the absurdity connected with the argument of change on a basis of the selection of infinitesimal differences. The femur of the whale, says 
Spencer, is evidently the atrophied rudiment of a bone once much larger. It weighs now about one ounce, less than a millionth of the weight of the whole body.

Spencer's example of the femur of the whale.
Let us suppose that when it weighed two ounces an individual had a femur which by variational chance weighed but one ounce. What advantage over other whales would the difference give it? What fraction of the daily nourishment would this advantageous variation permit the fortunate whale to add to its stored fat instead of spending it on an extra ounce of useless femur? Who would dare clain that this variation would aid in success in the struggle for existence? And yet this is the argument for the reduction of useless organs through the influence of natural selection. Roux and Weismann, realising the absurdity of the argument, have put forward two theories, one called the "battle of the parts" and the other the "theory of germinal selection" to aid the selection theory to explain the degeneration and reduction of organs. The reader will find these theories explained in chapter viii.

Every student of systematic zoology or botany has a keen realisation, too, of the fact that a majority of the distinguishing characters which he recognises in the vari-

Many species ous species and genera that come under his characters of no ntility. eye are of a sort that reveal to him no trace of particular utility or advantage. Indeed he can go farther and express, to himself at least, his conviction that many of these slight but constant specific differences ${ }^{10}$ can actually have no special advantageousness about them. One's experience as an observer of nature and one's common sense combine to protest against that easy and sweeping answer of the Darwinians: "shall 'poor blind man' say what characteristic, however slight and insignificant, is or is not of advantage in the great complex of nature?" As the whole question after all resolves itself into one for which "poor blind man" is attempting to find an answer satisfying 
to his own understanding, however short of perfection and omniscience that is, he is bound to answer the subsidiary problems such as usefulness or non-usefulness on a basis of his own seeing and understanding capacity. As a matter of fact the indifference of many specific characteristics of organisms is not denied by selectionists. Romanes ${ }^{11}$ was perhaps the first representative Darwinian, after Darwin himself, to admit this. But many biologists say, further, on a basis of their experience as observers, that these very indifferent, meaningless (as far as utility goes) morphological characteristics and differences are much more constant in their character than the obviously adaptive, $i$. e., useful ones. However, as pointed out first by Nïgeli, according to the selection theory the characteristics of organisms should be just in that degree the more constant, the more useful they are. Hence there is here a serious discrepancy between theory and fact. Darwin himself felt the force of this objection and met it in a manner not at all acceptable to the ultra-Darwinians, that is the strict selectionists of post-Darwinian times. He admitted that these trivial, apparently non-useful, but constant specific characters could not be explained by natural selection, and must be due to a fixation in the species of these characters at one time or another through the nature of the organism and the influence of extrinsic influences; a true Lamarckian or at least anti-Weismannian * explanation.

This objection to the selection theory based on the ad-

* Students and readers who have not read Darwin recently, or in the light of the controversy between the neo-Darwinians and the neo-Lamarckians, that is, between those who disbelieve and those who believe in the inheritance of acquired characters, will be surprised to note on a careful re-reading of the "Origin of Species," with this post-Darwinian sharp distinction in mind, how often Darwin calls on the Lamarckian factors to help his species-forming theories out of tight places. Morgan in his "Evolution and Adaptation" points out many cases of this. 
mitted existence of indifferent species characters is well stated

Conn's statement of the objection to selection based on trivial characters. by Conn ${ }^{12}$ as follows: "But how is it with characters that have no utility? It is, of course, a great achievement to be able to point out the method by which adaptations have been produced, but if animals have some characters that are not useful, natural selection does not explain them. Natural selection can develop useful organs only. The real problem which our naturalists are trying to solve is not the origin of adaptations simply but the origin of species also. Now while many of the characters and organs of animals and plants are of utility to the individual there are others that appear to be useless. As animals and plants are studied, it is found that the different species differ from each other by certain definite characters. These distinctive peculiarities that distinguish species are called 'specific charactcrs,' and this term will be hereafter used in this sense. The explanation of the origin of species must then account for the origin of specific characters. Now specific characters are frequently trivial in nature. This was long ago recognised by Darwin, who saw that the characters by which species are distinguished are frequently so trivial as to be apparently useless. If, however, we are to explain the origin of species we must find an explanation of these trivial characters as well as the more important ones. If these trivial characters are of no use to their possessors, then manifestly the principle of the survival of the fittest does not account for them. The fact that species are so commonly separated by characters that seem to be absolutely useless has led some of our keenest naturalists to insist that the survival of the fittest does not explain the origin of species, but explains only the origir of adaptations. At all events, it is clear that the problem of the utility of specific characters is a very fundamental one to the discussion of the principle of survival. 
"We here come to the first parting of the ways between scientists of different schools. On the one hand we find those who are so thoroughly convinced of the universality of the principle of natural selection that they insist that all specific characters are useful, however useless they may seem. It is beyond question that they are led to this belief in the utility of all characters, not from observation, but simply from their belief in the sufficiency of the law of natural selection. They tell us that we know too little of the actual life of organisms in nature to enable us to say that any given character is not of use; and to make a claim that anything, no matter how trivial, is useless, is simply to confess ignorance. We must acknowledge that many seemingly useless organs have been found to have utility as soon as the life habits of animals are better understood. Certainly, utility has been found more universal than was believed to be possible a quarter of a century ago. The followers of Darwin have given very much attention to this matter. They have pointed out many lines of utility hitherto not dreamed of. They have considered great multitudes of cases of seemingly useless characters, and by a little imagination have suggested some use to which they may be adapted. If one reads the recent works of Wallace, the most prominent advocate of this position, he will not fail to be impressed with the fact that utility is much more widely applicable as an explanation of seemingly trivial characters than might have been thought possible. The position held by this writer is, that inasmuch as the law of natural selection is a universal force which all admit, while all other forces of evolution are yet in dispute, and inasmuch as many seemingly useless organs have been shown to be of use, it is perfectly legitimate to claim that when we come to understand them, we shall find that all characters are of value, and that the principle of survival of the fittest has been concerned in the development of them all. If this is true, the survival 
of the fittest explains the origin of species as well as the origin of adaptations, since all specific characters are really adaptations.

"But on the other hand, many naturalists think that there are specific characters for which we cannot only see no utility, but which are demonstrably of no use. A few illustrations will serve to make the matter clearer. Certain insects are distinguished from each other in accordance with whether they possess one or two bristles on the head. Here is a character which appears to be constant, and which must therefore be explained by any complete theory of the origin of species. Can we imagine that the question of whether the animal has one or two hairs should ever have been of selective value? But if developed by natural selection, this character must at some time have been a matter of life and death. Again among snails, the shells commonly coil in the same direction in the same species, this fact making the direction of the coiling of the shell a specific character. But clearly this is not a matter of selective value, since living among the rest of the individuals will frequently be found some with their shells coiled in the opposite direction. Again, horses have small horny callosities on their feet. No one has suggested any possible use for them, but nevertheless they are present on the feet of all the species of the horse family. But the most curious fact is that while the horse has them on all four feet, the ass has them on only two. Now, upon the principle that utility is universal, it would be necessary to claim, not only that the presence of four callosities has been a matter of selective value in the horse, an extremely difficult thing to believe, but also that the presence of only two instead of four has been of selective value in the ass. This position approaches absurdity. Again, there are molluscs characterised by special markings of the shell, which markings are constant enough to be specific characters, and must, of course, be included in any explanation 
of the origin of species. But these marks are demonstrably of no use, since they are entirely covered by the epidermis of the animal when alive, and absolutely invisible. Again, some birds have slight differences in colour markings which separate species. Now these differences may perhaps be regarded as of use as protective or as recognition marks. But in some cases the colour markings are entirely concealed by other feathers and, being invisible, can be of no possible utility. It is hardly possible for one, unless he has decided previously to accept the all-sufficiency of natural selection, to believe that there can be any utility in the very slight differences in the shape of leaves of plants, in the microscopic markings of the hairs of different species of mammals, the exact numbers of the feathers in the tails of birds, the peculiar distribution of the veins in the wings of a butterfly, the microscopic markings in the scales on its wings, or a host of other similar trivial characters. When it is remembered that the selection principle would force us to insist that all of these characters are of value sufficient to protect their possessors at the expense of other individuals not possessing them, it is evident that the burden thrown upon the principle of survival becomes very great. When finally we come to characters of specific nature connected with colour markings which are invisible when the animal is alive, there is apparently no resource left except to conclude that the principle of survival because of utility does not account for everything."

It is indeed the general recognition by naturalists of the fact of the triviality or indifference of a majority of specific characters that has led to the recent renewal of the importance of isolation theories, particularly of geographical isolation. The rehabilitation of Moritz Wagner's theory of species-forming by migration and isolation is a conspicuous feature in present-day evolution discussion. The way in which isolation comes to the aid of selection, or even sup- 
plants it in the minds of some, in species-forming is pointed out in chapter ix, to which the interested reader may refer.

But in those cases where the differences or variation among individuals may be or obviously are of the character

Theswamping of useful ones, and where by comparing exor extinguishing tremes of this variation the life-and-death-
of favourable variationsby inter- determining worth of this utility might be breeding.

conceded, still what chance is there for the perpetuation of this advantage? Nägeli long ago pointed out that the extreme variations, that is, the rare variations, would in almost every case be inevitably extinguished by interbreeding. If a certain considerable variation occurred in one individual of a hundred born, in 20,000 individuals of the species 200 would have this worth-while variation. Now if the chances of mating are the same for all there would be 9,80I parings of individuals not showing the variations, ig 8 pairings between a varying individual and a non-varying one, and a single mating between two individuals both preserving the considerable variation. In fact every rare variation will, as Delage says, be immediately effaced by the dilution of the blood of the varying individual by that of the great mass of individuals not possessed of the particular variation. This inevitable swamping of the advantageous variations of individuals has long ago led to the practical giving up by Darwinians of any claims to speciesforming or evolution on the basis of extreme or rare variations and to the restriction of the selecting influence to masses. The species must be changed through the selection of it as a mass or unit rather than through the selection of special scattered individuals of it.

But for the selection of masses of individuals sufficiently considerable to avoid the extinguishing of the fortunate variations by interbreeding, and to insure a repetition of the advantage and an opportunity for its fostering and 
increase, there is necessary an extraordinary coincidence in the appearance of the needed variations in many forms at The needed co- the right time. That is, a theory based on chance incident occur- or accidental phenomena demands after all the rence of sereral variations at one assumption of the occurrence of phenomena time.

of the right kind at the right moment, and the persistence of such occurrences through a definite time-period. This is too much to assume, too much to ask even of those of the true faith, say the antagonists ${ }^{13}$ if of the selection theory. Krönig ${ }^{1 \overline{5}}$ makes sport of the selection doctrine by having his rather frivolous character, Sabüchwinski, undertake to have made, by a foolish clown, various trifling changes in all kinds of industrial products with the expectation of bringing them into the market. He is convinced that he will win a fortune by this, for he says to himself that the struggle for supremacy must work out the same in the industries as in nature, and in his case with the added advantage that the changes effected by even the most slender-witted boor must result better than those which are the outcome of perfectly blind chance. Indeed, from the very heart of the neo-Darwinian ranks come signs of dismay when this objection is faced. Weismann, leader of the ultra-selectionists, practically concedes the irrefutability of this objection to the Allmacht of selection when he introduces a statement of his latest theory, that of Germinal Selection, by saying: " "Knowing this factor [that of germi-

Weismann's admission of the serionsness of this objection.

nal selection] we remove, it seems to me, the patent contradiction of the assumption that the general fitness of organisms or the adaptations necessary to their existence are produced by accidental variations-a contradiction which formed a serious stumbling-block to the theory of selection." And the formulation of the theory of germinal selection is of itself a practical confession on the part of the foremost neoDarwinian of the inability of natural selection to explain 
species-forming without calling to its aid some effective factor to control in its beginnings the variation essential as the basis of the selective action.

Pfeffer ${ }^{17}$ and Wolff ${ }^{18}$ have been particularly keen and severe in their criticism of the selection theory on the basis of this objection. And Morgan ${ }^{19}$ in this country has also made effective use of this weapon in his destructive consideration of the Darwinian theories.

There is an additional point about this difficulty of the necessity for a certain regularity or reliability of variation

Necessity for in order to make a beginning basis for the action coincident ap- of selection. It is this. Close scrutiny reveals pearance of other the necessity often of the occurrence of severat
variations to make a certain coincident variations in order to make any onc one effective. characteristic positively advantageous. What advantage in the way of increased speed is a slight added length of leg without a simultaneously added strength of musculation; or an increase in size of antlers without a simultaneous increase in strength of neck muscles to support and manipulate the heavier head? What faint probability of the occurrence coincidently of the necessary variations (if determined only by chance, that is, the law of probability) to produce a gradual perfecting of so complex a structure as the vertebrate eye? Or, more, how inconceivable the coincidences, if variation is purely fortuitous, necessary to the simultaneous development of two exactly similar eyes: two eyes so intimately associated physiologically that normal sight is a function of both these separated organs working perfectly together. Is variation to be assumed to be governed by some law of bilateral symmetry? But I have shown for many cases ${ }^{20}$ that in such perfectly and fundamentally bilaterally symmetrical animals as insects neither the usual Darwinian fuctuating variation nor the rarer discontinuous or sport variation is governed at all by such a law. In fact the independence of the varia- 
tion phenomena in right and left members of bilaterally arranged pairs of organs as wings, antennæ, legs, etc., is a noticeable fact. This denial of the capacity of the selection of fortuitous slight variations to account for coadaptation and for the continuous perfecting of complex organs has been stated as follows: "It is highly improbable that for the steady perfecting of an organ, the variations needed by selection will always appear just at the right time." Or in more expanded form: "It is highly improbable that during the modification of a complex organ such as a whole body part, or during the gradual perfecting of an adaptive modification, the numerous necessary variations will appear successively in such series that a harmonious combination of the single variations will be possible." The objection certainly needs no elaboration. The Darwinian variations appear in all directions at all times in slight degrees with no determinate direction nor correlation. Selection is to find in these variations its only material with which to build up to wonderful complexity and perfection of coadaptation and correlation of parts ${ }^{21}$ on a basis of constant advantage, such an intricate but harmoniously adjusted compound organ as the human eye, in which the failure or imperfectness of a single minute part can at any time, during the course of development, rob the whole of any advantage whatever to the organism possessing it.

Wolff ${ }^{2}$ enlarges on the difficulty of explaining any identical structures of the animal body which appear in one Diffcolty of and the same organism to the number of two explaining repeated identical structares by selection. or more. "It cannot be explained," he says, "by selection, how the carnivores, for example, can have developed through fortuitous yet always similar variations, two such structures agreeing in all details as the back teeth, which have developed in course of time from small skin teeth. That a tooth can develop into such an admirable biting organ through chance variation may 
be explicable by selection, because we are accustomed to postulate thoroughly fortuitous and all-inclusive variation; but that the tooth standing next to it shall have varied always in exactly the same way so that the result of its development shall make it identical with the other one, is inexplicable by selection on a basis of fortuitous variation, but rather indicates that the change of form is ruled by law which we do not know. The attempt to discover it is the most imperative task for biologists to undertake."

Wolff ${ }^{23}$ follows this argument farther by discussing other particular examples, but they are all of the type of the one Spencer's pic- just set out. Spencer pictures the situation of ture of the inu- the herbivorous animals in a country of in-
tility of advantage in a single clement climate and populated by numerous direction.

carnivores. Now those herbivores which have the finest hearing will be soonest aware of the approach of the tiger, but those with keenest sight or most perfect sense of smell will also perceive, as soon, that it is time to flee. But what advantage over others will the first start in flight give them? Others less delicately endowed with sense organs but swifter of foot will, although starting a little later, have as good a chance to escape because of their more rapid running. Later may come snow and terrible cold. Those individuals best endowed with sense-organs or swiftest of foot will not necessarily be the most enduring or the best equipped with instincts to find shelter. The climate may decimate those which selection on the basis of special senses or speed has saved. But after the cold may come the summer drought. Those most heavily furred or warmestblooded which have successfully endured the low temperature and snow and ice of winter should be the first to suffer from the attacks of sun and drought and lack of food in the summer. Thus no individual has, because of advantage in any one character, any real and complete superiority which guarantees it success in all the phases of the struggle for 
existence: the advantages are scattered and compensated by disadvantages. ${ }^{24}$

In connection with the objection stated in the preceding paragraphs is that specially pressed by Wolff, although long Numerons use- ago strongly stated by Mivart, ${ }^{25}$ and one that ful characteris- has long appealed strongly to me particularly in tics useful only connection with the study of the utility of fected state.

colour and pattern among insects. This objection is, that numerous useful characteristics or adaptations of organisms are useful only in a highly perfected state, often involving a complex and considerable structural development of old (then much modified) or quite new parts, and hence could not have arisen by gradual modification by the selection of slight variations. Darwin himself says that if a single complex organ can be referred to whose full development cannot possibly be explained through numerous small successive modifications, then his theory must indubitably fall. For example, the electric organ of the torpedoes, the brood-sacks or cells on the back of Pipa dorsigera, the chameleon's tongue, and many other organs can be recalled which could not possibly exercise their particular advantageous function in an undeveloped and beginning state. In my own eyes has for long stood the familiar case of the mimicry of our common American monarch butterfly, Mimicry of Anosia plexippus, by the viceroy butterfly, Anosia by Basilarchia archippus. The viceroy belongs to a Basilarchia, group of species in which the prevailing (almost certainly the ancestral) colour and pattern are white and black (or iridescent purplish and bluish) arranged as a broad white continuous transversal bar across both fore and hind wings, on a black (to purplish) ground. The colour and pattern of Anosia are radically different; brick-red ground, black longitudinal lines following the veins and small white spots in an irregular black submarginal band. Examine the viceroy butterfly. You find no suggestion of typical Basi- 
larchia type of colour and pattern; on the contrary, you find an extraordinarily faithful imitation (duplication) of Anosia's colour and pattern. Only in a narrow black transversal streak across the outer disc of each hind wing is there any divergence in the viceroy from the Anosia pattern. Now Anosia is distasteful to birds; after a few experiments with Anosia a bird recognising this ill-tasting morsel in its conspicuous red-brown livery leaves the monarchs alone. Not only monarchs, however, but also viceroys, which are to all external seeming only slightly smaller monarchs. The viceroy is, however, not distasteful; it would be a welcome bonne bouche to any bird that could distinguish it. But thanks to its perfectly mimicking colour-pattern it wings its deceitful way unmolested. There is huge usefulness here, and selection can well be the steadfast maintainer of the viceroy's dissimulation. But of what avail for this purpose of deceit was the first tiny tinge or fleck of red-brown on the staring black and white wings of the ancestral viceroy? How can one possibly conceive of an attainment of this identity of pattern between mimicker and mimicked by selection on a basis of life-or-death-determining advantage of slight chance appearances of brown or reddish flecks or tinges in successive viceroys? Not until practically full development of the mimicry pattern existed can this pattern have worked its advantage. It is, indeed, a different matter with many, perhaps most, cases of general or special protective resemblance. A little green, a little brown could obviously help the insect living in green foliage, or on the ground. Every change of tinge toward the general environing colour is worth while; it helps melt the insect into its inanimate surroundings. But with mimicry it must be the whole thing or nothing; or at least near enough to the whole thing to pass for it. Wolff puts the objection about as follows: There are compound organs and complex adaptations, whose complication (he would better say, whose advantage due to complication) can 
only be reached by a leap, while the selection theory presupposes slight gradual stages of complication.

Wolff ${ }^{26}$ expresses another phase of this objection by referring to a few of many cases of complex relations between

Difficalty of explaining complex relations among bodyparts by selection. entirely distinct organs in the body, which relations constitute some of the most important functions of the body. For the successful establishment of these relations it has been necessary, as Wolff expresses it, "that for each advance in development or complexity of one definite peculiarity in an organ there must appear corresponding and exact definite advance in development or complexity of a peculiarity in another entirely distinct organ." Wolff's first example is the relationship existing between the muscles: and nerves of the higher animals. The intimate, delicate, and precise character of the relations between the nerve-endings and the muscle cells, to be explicable by selection of fortuitous variations, must have required coincident variations both in structure and functions of each muscle cell and each nerve-ending that are impossible to conceive of. "It might be," says Wolff, "possible to picture the gradual development of the relations between one muscle cell and one nerve-ending on the basis of a selection among infinitely fortuitous variations, but that such variation shall occur coincidently in time and character in hundreds or thousands of cases in one organism is inconceivable."

In the case of organs whose functions are regulated from a common centre, the development of centre and of organs must have gone on coincidently and could not have been independent. The development of the eye is useless if the development of the optic centre did not go hand in hand with it. Without the one the other has no reason, no significance, therefore selection could have brought neither to its proper development independently. The coincident appearance, however, of organ and centre can 
be explained by the selection theory only when there is postulated a definite degree of complexity of the fortuitously appearing slight variations, that is, when this theory is in condition to assume that which would be a denial in terms that variations are wholly fortuitous. Wolff goes on to give certain examples of such complex relations which involve a dependence of the use upon an instinct, as the performance by the queen honey-bee of her particular functions in the hive, etc.

"Out of this discussion," says Wolff, "finally we must postulate that structures which are to be explained by the selection theory must possess at the least two certain characteristics. Such a structure, namely, must occur but once in an organism [that is, must not be a serially or bilaterally repeated organ, nor indeed appear in any condition of plural number]; further, it must not stand in any necessary relation to any other part of the same organism, that is, in a relation which one can interpret as a relation not existing from the beginning, therefore one which must be looked on as an acquired relation. But if we survey the whole animal kingdom it will be very difficult for us to find any structures which satisfy both these requirements. It might be possible to find some which perhaps seem to satisfy the second requirement, but with regard to the first requirement I may declare," says Wolff, "that there is scarcely a single structure which fulfils it. Symmetry alone, which rules almost all organisms, makes organs which appear in the singular number rarities, and even such as the pancreas, etc., are composed of many finer structures, which are homodynamous among themselves. When we find two similar organs in different animal groups we seek for a catısal explanation of this similarity and find it in common ancestry. It is absurd to seek a causal explanation for the origin of homologous structures and yet postulate a purely chance or fortuitous explanation for the origin of homodynamous structures." 
Another objection which the study of the utility of colour and pattern ${ }^{27}$ also has impressed upon me is that of the

Objection based on over-specialisation,

carrying too far of certain lines of modification. Classic examples are the fatal over-development of the antlers of the extinct Irish stag, the unwieldiness of the giant Cretaceous reptiles, the intimate identity of the halves of bilaterally symmetrical animals. Let me call attention to an overdone case of "protective resemblance" among the insects. It is that of the famous Kallimas, the dead-ieaf butterflies of the Malayan and general south tropical regions. These butterfies (there are several species which show the marvellous imitation) have the under sides of both fore and hind wings so coloured and streaked that when apposed over the back in the manner common to butterflies at rest, the four wings combine to Kallima, the resemble with absurd fidelity a dead leaf still deas-leaf butter-attached by a short petiole to the twig or branch. fly.

I say absurd, for it seems to me the resemblance is over-refined. Here for safety's sake it is no question of mimicking some one particular kind of other organism or inanimate thing in Nature which birds do not molest. It is simply to produce the effect of a dead leaf; any dead leaf; a brown, withering leaf on a branch. Leaf-shape and general dead-leaf colour scheme are necessary for this illusion. But are these following things necessary? namely, an extraordinarily faithful representation of mid-rib and lateral veins even to faint microscopically-tapering vein tips; a perfect short petiole produced by the apposed "tails" of the hind wings; a concealment of the head of the butterfly so that it shall not mar the outlines of the lateral margin of the leaf; and, finally, delirate little flecks of purplish or yellowish brown to mimic spots of decay and fungus-attacked spots in the leaf (!) and, as culmination, a tiny circular clear spot in the fore wings (terminal part of the leaf) which shall represent a worm-eaten hole, or a piercing of the dry leaf 
by flying splinter, or the complete decay of a little spot due to fungus growth! A general and sufficient seeming of a dead leaf, object of no bird's active interest, yes, but not a dead leaf modelled with the fidelity of the wax-workers in the modern natural history museums. When natural selection had got Kallima along to that highly desirable stage when it was so like a dead leaf in general seeming that every bird sweeping by saw it only as a brown leaf clinging precariously to a half-stripped branch, it was natural selection's bounden duty, in conformance with its obligations to its makers, to stop the further modelling of Kallima and just hold it up to its hardly won advantage. But what happens? Kallima continues its way, specifically and absurdly, dead-leafwards, until to-day it is a much too fragile thing to be otherwise than very gingerly handled by its rather anxious foster-parents, the neo-Darwinian selectionists.

An objection which was long ago pointed out, and which has been emphasised strongly by some biologists and almost overlooked by others, is that of the incom-

Geologic time too short to give selection opportunity to do its work. patibility of the results concerning the age of life on this earth as propounded by physicists and astronomers with the demand made by the theory of descent. This objection of the lack of time for the production of the hosts of kinds of plants and animals through the slow workings of natural selection was brought forward against Darwin from the very beginning and has never been given up. De Vries, ${ }^{28}$ for example, in a recent paper, refers to it as follows:

"The deductions made by Lord Kelvin and others from the central heat of the earth, from the rate of the production of the calcareous deposits, from the increase in the amount of salt in the water of the seas, and from various other sources, indicate an age for the inhabitable surface of the earth of some millions of years only. The most probable estimates 
lie between twenty and forty millions of years. The evolutionists of the gradual line, however, have supposed many thousands of millions of years to be the smallest amount that would account for the whole range of evolution, from the very beginning until the appearance of mankind. This large discrepancy has always been a source of doubt and a weapon in the hands of opponents of the evolutionary idea, and it is especially in this country that much good work has been done to overcome this difficulty. The theory of descent had to be remoulded. On this point conviction has grown in America during the last decades with increasing rapidity."

However (according to a newspaper clipping), Professor Lankester, $^{29}$ a present-day Darwinian champion, in the Radinm a pos- course of an interesting outline of the advancesible answerto ment of science in the past twenty-five years the objection. which he gave at the opening meeting of the British Association at York recently (September, I906) again raised the question of the age of the earth. Referring to the discovery of radium as one far exceeding in importance all other modern scientific discoveries he said that if the sun contained a fraction of one per cent. of radium, this radium would account for and make good the heat that is annually lost by the sun. "This is a tremendous fact, upsetting all calculations of physicists as to duration in past and future of the sun's heat and the temperature of the earth's surface. The geologists and the biologists have long contended that some thousand million years must have passed during which the earth's surface has presented approximately the same conditions of temperature as at present, in order to allow time for the evolution of living things and the formation of aqueous deposits of the earth's crust. The physicists," contended Professor Lankester, "notably Professor Tait and Lord Kelvin, refused to allow more than ten million years (which they have subsequently increased to a hundred million, basing the estimate on the rate of 
cooling of a sphere of the size and composition of the earth). They have assumed that its material is self-cooling. But as Huxley pointed out, mathematics will not give a true result when applied to erroneous data. It has now, within the last five years, become evident that the earth's material is not self-cooling, but on the contrary self-heating, and away go the restrictions imposed by physicists on geological time. They are now willing to give us not merely a thousand million years, but as many more as we want."

In this connection should be mentioned the position taken by Ammon ${ }^{30}$ and others who argue that the real effect or Claim that se- result of natural selection is to preserve the lection hinders type at the expense of the variants, which would

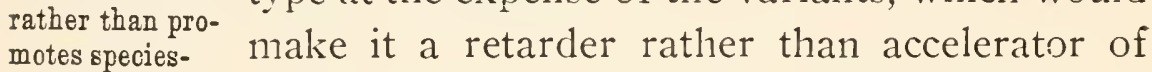
change. species-change. Bumpus's ${ }^{31}$ observations on, and conclusions concerning, his storm-beaten English sparrows is an example of what Ammon claims must be the real result of selection. Bumpus, in statistical studies of the variation of two animal species introduced from Europe into the United States, viz., the English sparrow and the periwinkle, Littorina littorca, shows that the eggs of the sparrow and the periwinkles themselves are much more variable in

Bumpus's observations on sparrows.

America than in their native regions, and the author attributes this increased variability to their "presumable emancipation from many of the restraining influences of natural selection." In the case of the English sparrows, also, Bumpus believes himself able to show on a basis of the examination of I 36 birds brought in wounded or stunned after a severe storm of snow, rain, and sleet (Feb. I, I898), that the sixty-four birds that perished (seventy-two revived), "perished not through accident, but because they were physically disqualified, and that the birds which survived, survived because they possessed certain physical characters. These characters enabled them to withstand the intensity of this particular phase of selective 
elimination and distinguish them from their more unfortunate companions." The fortunate characters were masculinity, shortness of body, lightness, longer humerus, longer femur, longer tibio-tarsus, longer sternum, greater brain capacity. But more important for survival than favourable variations was the fact of approach to the species type or mode of variability. The extreme variants perished. "The process of selective elimination is most severe with extremely variable individuals, no matter in what directions the variations may occur. It is quite as dangerous to be conspicuously above a certain standard of organic excellence as it is to be conspicuously below the standard. It is the type that nature favours."

\section{APPENDIX.}

${ }^{1}$ For a fairly complete bibliography, with excellent abstracts, of all important critical discussions of Darwinism since 1895, see L'Annćc Biologique (ed. Y. Delage), I895-1903; for good bibliography also see Zoologischer Jahresbcricht, issued annually. See also discussions and notes in such journals as Natural Science, Biologisches Centralblatt. Nature, Scicnce, American Naturalist, etc.

${ }^{2}$ Von Kölliker, A., "Über die Darwin'sche Schöpfungstheorie," Zeitsch.f. ai'ss. Zool., Vol. XIV, pp. 174-186, I864.

${ }^{8}$ Korschinsky, S.. "Heterogenesis und Evolution," Natura". Wochenschrift, Vol. XIV, pp. 273-278, I899.

"Morgan, T. H., "Evolution and Adaptation," I903. A vigorous anti-Darwinian argument, somewhat sophisticated in its lawyerlike handling of Darwin's own words, but keen and trenchant in its exposure of the weaknesses of the selection theories as speciesforming explanations. It is also a brief for de Vries's theory of species-forming by mutation. (See chap. xi of this book.)

s"See Osborn, H. F., "Biol. Lectures," Wood's Holl Lab., I894, pp. 79-100, for suggestive plea for the recognition of "the unknown factors of evolution."

'The subject of variation, an absolutely fundamental one in any consideration of the factors and mechanism of organic evolution, has

Books and paa very large literature pertaining to it which the pers on variation. serious student of evolution must make considerable acquaintance with at the very outset. Of this literature the following books and papers may be suggested to serve as 
a means of introduction to the subject, not alone in its broad outlines, but in its extensive ramifications of relation to other evolution problems. Some of these books and papers include extended bibliographic lists sufficient to enable one to follow up the subject in any of its special phases.

Darwin, Chas., "The Origin of Species," 1859.

Darwin, Chas., "The Variation of Animals and Plants under Domestication" (Amer. ed.), I868.

Wallace, A. R., "Darwinism," chaps. iii and iv, I89I.

Allen, J. A., "On the Mammals and Winter Birds of East Florida," Bull. Mus. Comp. Zool., II, pp. I6I-450, Plates IV-VIII, I87I.

Galton, F., "Natural Inheritance," I889.

Bateson, W., "Materials for the Study of Variation," 1894.

Duncker, G.. "Die Methode der Variationsstatistik," Archiv f. Entruick. Mech., Vol. VIII, pp. II2-183, 1899. (Full bibliography.)

Rosa, D., "La riduzione progressiva della variabilita i suoi rapporti coll' esstinzione e coll' origine delle specie." I899.

Conn, H. W.. "The Method of Evolution," chap. iv, I900.

Davenport, C. B., "A History of the Development of the Quantitative Study of Variation," Science, N. S., Vol. XII, pp. 864-870, 1900.

De Vries, H., "Die Mutationstheorie," Vol. I, pp. 7-I50, pp. 4I2-648, I90I.

Ewart, J. C.. "Variation; Germinal and Environmental," Trans. Roy. Dublin Soc., Ser. II, Vol. VII, pp. 353-378, I90I.

Vernon, H. M., "Variation in Animals and Plants," 1903.

Delage, Y., "L’Hérédité," pp. 283-310, pp. 826-843, 2 d ed., I903.

Davenport, C. B., "Statistical Methods in the Study of Variation," 2d ed., 1904. (Full bibliography.)

Kellogg and Bell, "Studies of Variation in Insects," Proc. Wasl. Acad. Sci., Vol. VI, pp. 203-332, 1904.

Lotsy, J. P., "Vorlesungen über Descendenztheorien," Vol. I, chap. ix. I906.

Biometrika, I90I-Igo6. A journal devoted chiefly to the statistical study of variation.

"See Kellogg, "Variation in Parthenogenetic Insects," Science, N. S., Vol. XXIV, pp, 695-699, I906, in which it is shown that the Cases of marked parthenogenetically produced drone honey-bees vary variation in par- much more than do the workers which are of bithenogenetic ani- sexual parentage, and that parthenogenetically promals. duced plant-lice (Aphidids) vary as markedly as insects of bisexual parentage. See also Warren, Proc. Roy. Soc., Vol. LXV, I899, in which the variation in parthenogenetic variations of Daphnia magna is shown to be little, if any, smaller than 
in sexually produced generations; also, Biometrika, Vol. I, pp. I29I54. 1902, in which Warren shows the variation in parthenogenetic series of the plant-louse Hyalopterus trirhodus to be as large as the variability exhibited in sexual forms.

See also Haycraft, J. B., "The Rôle of Sex," Nat. Science, Vol. VII, pp. 245-250, 342-344, I895, in which paper is presented an ingenious argument to show that sexual reproduction tends not merely not to increase variation but to decrease it: "the convergence to the mean is, then, a result of sexual reproduction: it may be termed the rôle of sex, and one indeed of no secondary order. The tendency constantly to vàry is a property inherent in protoplasm, yet often for long periods of time the environment may be the same. In order that a species may continue to live in such a constant environment, the effects of variation must be checked. Sexual multiplication, a conservative function, antagonises the progressive tendency of variation."

Other naturalists have also held strongly to this view of the rôle of amphimixis. See Bailey, L. H., "The Plant Individual in the Light of Evolution," address before the Biological Society of Washington, January 12, I895. Science, N. S., Vol. I, p. 28I. I895, in which paper the author points out the importance of a clear recognition of the tremendous possibilities and actuality of asexual variation in plants.

In a paper by Winslow and Rogers (Science. N. S.. Vol. XXI., p. 486. 1905), referring to the classification of bacteria, there is the following statement: "Since the swamping of minor differences by sexual reproduction is absent from bacteria, every inheritable variation is maintained, and instead of true species, we find an infinite series of minutely differing but constant races. The only practical method of handling and systematising these. is to establish certain fairly distinct groups and types about which the individual variations may be grouped."

${ }^{8}$ By using a large series of individuals, and carefully tabulating the noted conditions of variation of one or more parts. using, preferably, attributes whose variability is capable of being

Variation according to the law mathematically expressed, such as dimensions, numof probabilities.

bers of spines, or spots, etc., many students have shown that these variations seem to occur in most cases according to the law of probabilities, and that a curve plotted so as to express graphically the actual conditions of variation for a given character would be nearly identical with the curve that could be plotted so as to express what variation would exist in the given case if this variation occurred exactly according to the laws of chance. This means that in a thousand individuals collected at 
random and examined for variation in any character, say total length of body, not only would there be found a larger number of individuals of medium length than of any other length between the two extremes, represented by the longest and shortest individuals, but that the various lengths between the mean and the longest and between the mean and the shortest, would be represented by groups of individuals regularly decreasing in number as the length increased or decreased on either side of the mean, but of equal number if compared at equal amounts of difference away from the mean.

The curve expressing graphically the law of probabilities or, better, the frequency of error, is determined by the formula for this frequency deduced originally by Gauss at the beginning of the last century. It would lead us too far afield to reproduce here the mathematical proof of the formula or method of its determination, but Vernon's excellent concrete illustration of how such a formula could be deduced directly from a study of biologic variation may be quoted. "Supposing," says Vernon in "Variation in Animals and Plants," pp. II and I2, I903, "a group of developing organisms be taken, of which the growth can be affected in a favourable or an unfavourable manner by their surroundings. Let us suppose that there are twerity different agencies, each of which would produce an equal, favourable effect on growth, and twenty which would produce just as great an effect in the opposite direction. Suppose, also, that each organism is subjected to only half of these forty different agencies; then it would follow, according to the laws of chance, that a larger number of the organisms would be acted upon by Io favourable and Io unfavourable agencies, than by any other combination; i.c., they would, on our hypothesis, remain absolutely unaffected in their growth. A somewhat smaller number would be acted upon by II favourable and 9 unfavourable agencies, or on the whole, would have their growth slightly increased. A still smaller proportion would be acted on by $\mathrm{i} 2$ favourable and 8 unfavourable agencies, or would have their growth rather more increased. Finally, the number of organisms acted on by 20 favourable and o unfavourable agencies would be extraordinarily small, but in this case the effect on growth would be extremely large. Similar relationships, only in the reverse direction, would of course be found in those cases in which the number of unfavourable agencies exceeded the number of favourable. If desired, the proportional numbers of organisms acted on by all the different combinations of agencies may be readily determined by expanding the binomial $(1 / 2+1 / 2)^{20}$. It is found, for instance, that for each single time the organisms are acted on by the whole 20 favourable agencies, they are acted on Igo times by 18 favourable and 2 unfavourable; I5,504 times by 15 
favourable and 5 unfavourable; and no less than 184.756 times by Io favourable and io unfavourable. Let us consider that the organisms acted on by 20 favourable and o unfavourable agencies have their size increased 20 per cent.; those acted on by 15 favourable and 5 unfavourable by $15-5=10$ per cent.; and so on. If now these percentage increments and decrements be plotted out at equal distances on a base line, and ordinates corresponding to the theoretical frequencies erected from each, then by joining these ordinates we shall obtain a curve which is practically identical in form with the probability curve of the law of frequency of error. Thus, by a simple arithmetical method, we obtain a series approximating more and more closely to the probability curve. the greater the number of times the expression $(1 / 2+1 / 2)$ is expanded. Expanded 20 times, the average error is less than .5 per cent., and for a greater number of times it becomes rapidly smaller and smaller."

This discovery and formulation of the law of individual variation-namely, that such variation occurs according to the law of Quetelet, the probabilities-was first made by the Belgian anthroQuetelet, the
discoverer of vari- pologist, Quetelet ("Lettres sur la théorie des Probaation according bilités." Brussels, I846), on a basis of the examinato the law of tion of the height and chest measurements of soldiers. chance.

It was later elaborately confirmed by Francis Galton (numerous papers and the book, "Natural Inheritance," I870-I890), by quantitative determinations of the height, weight, span of arms, breathing capacity, strength of pull, strength of squeeze, swiftness of blow, and keenness of sight in men and women. It has been most illuminatingly discussed by Karl Pearson in "The Chances of Death, and other Studies in Evolution," 2 vols., 1897. Since then the recognised necessity of a more thorough study and understanding of variation, as the indispensable foundation of species-forming has led to a large development of the statistical and mathematical study of variation, under the name of biometry, a study largely due to the initiative and genius of the English mathematician and natural philosopher, Karl Pearson (numerous papers from I894 to present). Most of the methods and formulæ for determining precise mathematical expression of variation conditions have been devised by him. These methods and formulæ permit of an actual mathematical comparison of variation among various parts in one species (immensely enlarging our definite knowledge of structural correlations), or among similar or wholly different parts in various species. With the statistical facts or data of variation thus put into precise mathematical expression, these expressions may be submitted to a deal of independent mathematical treatment; rather bewildering, it must be confessed, to most biologists, but presented by the biometricians 
as the first step toward making biology, in part, at least, an exact science. But there is no question at all that the statistical and quantitative study of variation, and the use of authoritatively deduced mathematical expressions (and the graphic representation of these by plotted frequency curves, polygons, etc.), have immensely advanced our understanding of variation conditions, and given us definiteness and concreteness in a fundamental field of evolution study, where before were a mass of uncoördinated data and a haze of loose generalising.

'Bateson, Wm., "Materials for the Study of Variation," I894.

${ }^{10}$ See Kellogg and Bell, "Studies of Variation in Insects," Proc. Wash. Acad. Sci., Vol. VI, pp. 203-332, I904, in which are discussed Example of bird beetle, Hippodamia convergens. The variations

(pp. 257-273) variation conditions existing in the ladyin the number and character of the elytral pattern (small black spots on a brown ground) noted in a thousand specimens examined, were such that eighty-four "aberrations," or pattern-variates, could be distinguished and described, and yet, an intensity of scrutiny demanding the use of a lens was necessary to distinguish properly these varying types. Such a scrutiny, needless to say, will never be given these beetles by bird or lizard, the active agents representing natural selection, as far as pattern is to be tested. Nevertheless, these pattern variations, if not so completely connected by gradatory steps, would be exactly the characters on which several Hippodamia species would be based, for they range all the way from no spots to eighteen spots, although twelve is the species character of convergens.

${ }^{11}$ Romanes discusses this subject of the indifference, or triviality, of many specific characters at some length in chap. vii of his "Darwin and After Darwin," II, "Post-Darwinian Questions," "Heredity and Utility." I 895.

${ }^{12}$ Conn. H. W., "Method of Evolution," pp. 78-83, 1900.

${ }^{13}$ Nägeli, Carl, "Mechanisch-physiologische Theorie der Abstammungslehre," ISS4. Nägeli, an eminent botanist, formulated many

Nägeli's seven years ago the following famous seven objections to objections to spe- the natural selection theory of species-forming ( $\mathrm{pp}$. cies-forming by 289-290) :

selection.

"Ich hebe folgende sieben Gesichtspunkte hervor, welche uns die Abstammung durch Zuchtwahl unannehmbar machen:

"I. Bezüglich der allgemeinen Bedeutung der Selectionstheorie ist die unbestimmte Wirkung unbestimmter Ursachen und die dem Zufall allzusehr überlassene Entscheidung durch die natürliche Zuchtwahl unserem naturwissenschaftlichen Bewusstsein weniger zusagend. Ferner setzt sich die Selectionstheorie, welche ihrem 
Princip gemäss nur nach dem erreichten Nutzen einer Erscheinung. fragt, um dieselbe zu rechtfertigen, in Widerspruch mit der wahren und exacten Naturforschung, welche vor allem die bewirkenden Ursachen der Dinge zu erkennen sucht.

“2. Die Folgerung von der (künstlichen) Rassenbildung auf die (natïrliche) Varietätenbildung, welche die Grundlage der Selectionstheorie ausmacht, ist unzulässig, da beide wesentlich verschieden sind und namentlich sich rücksichtlich der Kreuzung ungleich verhalten. Die Varietäten nämlich vermischen sich sehr schwer mit einander und nehmen kein fremdes Blut in irgend wirksamer Menge auf, werden somit auch durch die ihnen gebotene Gelegenheit zur Kreuzung nicht verändert; mit diesen Eigenschaften stimmen ihre Vorkommensverhältnisse genau überein.

"3. Nützliche Veränderungen können erst, wenn sie eine bemerkbare Höhe erreicht haben und in zahlreichen Individuen vorhanden sind, eine ausgiebige Verdrängung der Mitbewerber bewirken. Da sie aber im Anfange durch eine lange Reihe von Generationen jedenfalls noch sehr unbedeutend und nach der Selectionstheorie auch nur in einer kleinen Zahl von Individuen vertreten sind, so bleibt die Verdrängung aus und eine natürliche Zuchtwahl kommt, da ihr der wirksame Hebel mangelt, überhaupt nicht zu Stande.

"4. Die Ernährungseinflüsse, welche die Selectionstheorie voraussetzt, bewirken thatsächlich keine erblichen Veränderungen, und wenn sie es thäten, so könnte eine Steigerung der begonnenen Abänderung nicht eintreten, weil die unvermeidliche Kreuzung eine natürliche Zuchtwahl unmöglich machen würde. Ferner lässt sich aus den unbestimmten, in allen denkbaren Richtungen wirkenden Ernährungseinflüssen der so stetige phylogenetische Fortschritt zu einer complicirteren Organisation nicht erklären. Ebenso wenig werden durch dieselben die Erscheinungen der Anpassung verursacht; dies ergibt sich einerseits aus dem Umstande, dass Gebrauch und Nichtgebrauch die $\mathrm{Zu}$ - und Abnahme der Organe bedingen, da diese Ursache für sich vollkommen ausreicht und daher die Mitwirkung einer zweiten andersartigen Ursache ausschliesst,- -und andrerseits durch den ferneren Umstand, dass Anfänge von Organen bis zu der Grösse, wo sie in Gebrauch kommen und ihre Nützlichkeit zu erproben vermögen, mangeln. obgleich sie durch die Ernährungseinflüsse in Menge hervorgebracht werden müssten.

"5. Die Eigenschaften der Organismen müssten in Folge der natürlichen Zuchtwahl um so constanter sein, je nützlicher sie sind, und Einrichtungen, die keinen Vortheil gewähren, könnten keine Beständigkeit erlangen. Im Widerspruche hiermit gehören gewisse. rein morphologische, mit Rücksicht auf den Nutzen indifferente Merkmale zu den allerbeständigsten. 
"6. Aus der Selectionstheorie, nach welcher von den eintretenden richtungslosen Veränderungen bloss die nützlichen festgehalten würden, lassen sich weder die Divergenz der Reihen in den organischen Reichen, noch die bestehenden Lücken in und zwischen den Reihen erklären, indem vielmehr eine netzförmige Anordnung der Sippen zu Stande kommen müsste.

"7. Ebenso widersprechen jener Theorie das Nichtvorhandensein der von ihr behaupteten gegenseitigen Anpassung der Bewohner eines Landes und die bestehenden Naturalisationen fremder Erzeugnisse.

"Diese Einwürfe gegen die Selectionstheorie, die ich hier bloss ganz allgemein formulirt habe, sollen im folgenden des Näheren begründet werden."

${ }^{1 *}$ Wolff, G., "Beiträge zur Kritik der Darwin'schen Lehre," I 898. From this caustic attack on the Darwinian position, I quote as follows (pp. 56-57):

"Wenn wir sagen, die Selektion schafft Zweckmässiges dadurch, dass eben nur das Zweckmässige erhalten wird, das andre zu Grunde geht, so wird in dieser Fassung das Zweckmässige

Wolff's attack natürlich vorausgesetzt, aber nicht sein Zustandekomon the selection- men erklärt. Dass Zweckmässiges überhaupt da war, ists' assumption
of the appearance at the right time ständlich. Mochte auch unter den vielen Variieof the needed rungen manchmal etwas Zweckmässiges zufällig variation. vorgekommen sein, so ist die Wahrscheinlichkeit eines solchen Eintreffens so gering, dass ich nicht das Recht habe, diesen Faktor als einen gegebenen in meine Rechnung einzusetzen. Diese Wahrscheinlichkeit sucht nun der Darwinismus dadurch zu vergrössern, dass er alle möglichen Fälle annimmt, unter welchen natürlich auch das Zweckmässige als Spezialfall enthalten sein muss. Der Darwinismus sucht also den Treffer sich dadurch zu sichern, dass er den ganzen Glückshafen mit nach Hause nimmt.

"Um ein Beispiel zu nehmen: es sei von Vorteil, dass die Schnabelform entsteht, wie sie beim Kreuzschnabel vorhanden ist. Der Darwinismus nimmt an, dass durch glückliche Variierung ein bezw. mehrere oder sogar viele gekreuzten Schnäbel auftraten. Sagt nun der Gegner: das spontane Auftreten einer Schnabelkreuzung scheint mir so unwahrscheinlich, dass ich diese Voraussetzung eben nicht zugebe, so antwortet der Darwinist: unter allen möglichen Schnabelvariierungen ist auch der gekreuzte, darf ich alle, so darf ich a oh diesen voraussetzen; da aber die Variierung, wie die Beobachtung lehrt, nach allen Richtungen beliebig wirkt, so sind alle Variierungen möglich, folglich darf ich auch jene spezielle voraussetzen.

"Der Gegner würde jetzt vielleicht so erwidern: Gewiss, möglich sind alle Variierungen, aber gegeben ist deren doch immer nur eine 
begrenzte Anzahl. Die Zahl aller möglichen Variierungen ist $=\infty$, die Zahl der gegebenen ist eine endliche Grösse. Die Wahrscheinlichkeit des Eintretens einer speziellen zweckmässigen Variierung (in unserm Beispiel der zweckmässigen Schnabelkreuzung) ist Endliches dividiert durch Unendliches, d. h. eine Zahl, welche sich der Null ohne Ende nähert; mithin ist die Wahrscheinlichkeit, dass unter den gegebenen Fällen sich eine günstige Variierung befindet, so ungeheuer klein, dass nicht die geringste wissenschaftliche Berechtigung besteht, den betreffenden Fall vorauszusetzen. Und nun würde allerdings demjenigen Darwinisten, welchem die Kühnheit fehlte, die Zahl der ihm zur Verfügung stehenden Variierungen einfach $=\infty$ zu setzen, wohl haum etwas andres übrig bleiben, als sich darauf $z u$ berufen, dass es eine Sorte von Variierungen giebt, bei denen die Zahl der gegebenen Fälle gross genug ist, um alle möglichen zu enthalten, gross genug also, um die Voraussetzung jedes einzelnen wissenschaftlich zu rechtfertigen, nämlich diejenigen Variierungen, welche nur in graduellen Veränderungen bestehen, bei denen es sich also nur darum handelt, dass ein Vorhandenes grösser oder kleiner wird. Hier ist die Zahl der möglichen Fälle gleich 2, die der gegebenen ebenfalls, die Wahrscheinlichkeit, sich unter den gegebenen zu befinden, ist also für jeden der möglichen Fälle gleich I."

${ }^{15}$ Krönig, "Das Dasein Gottes und das Glück des Menschen," p. 109. 1874 .

${ }^{16}$ Weismann. Aug., "On Germinal Selection as a Source of Definite Variation," trans. McCormack, p. 3 (preface), I896.

${ }^{17}$ Pfeffer, Georg, "Die Umwandlung der Arten," I894.

${ }^{18}$ Wolff, G., "Der gegenwärtige Stand des Darwinismus," IS96; also, "Beiträge zur Kritik der Darwin'schen Lehre," isg8.

${ }^{19}$ Morgan, T. H.. "Evolution and Adaptation," Ig03.

${ }^{20}$ Kellogg and Bell, "Studies of Variation in Insects," Proc. Wash. Acad. Sci., Vol. VI, pp. 203-332, I904. The following is quoted from pp. 330-332:

"Insects are bilaterally symmetrical and metameric animals. There are thus right and left and fore and aft structural correlations. Do the

Example of non- variations, continuous and discontinuous, show similar correlated varia- bilateral and metameric correlation? Evidence regardbility in bilater- ing this question will be found on many pages in the ally repeated present paper, right and left correlation. at least, havorgans.

ing been considered and briefly discussed in connection with almost all of the various cases studied. And the evidence is curiously conflicting. For example, in the male black ant in which were studied the variations of the venation and number of hooks, a close correlation in the variation conditions of right and left wings 
exists. On the other hand, in the honey-bee the bilateral correlation of variation seems surprisingly small (see pp. 214-222). In the case of variations in pattern, also, there is no uniformity among the various cases studied. In Hippodamia convergens (p. 257 ct scq.) the two elytra show pattern-variations quite independently; in Diabrotica soror ( $\mathrm{p} .274$ et seq.), on the contrary, there seems to be a marked right and left correlation in the elytral patternvariation. In the cases of the variation in number of tibial spines on the right and left hind tibix of locusts (p. 30I) and cicadas (p. 306), we have simply made a brief statement, in each case, of the actual conditions of correlation, leaving the reader to draw his own conclusions. In the case of the variation in actual and relative length of the antennal segments of the scale insect, Ceroputo yucce (?) (p. 310), there is a surprising lack of correlation between the right and left antennæ.

"We have not attempted to determine the mathematical expression (coefficient of correlation) for any of the cases studied. The data presented, however, will enable any biometrician, who sees an advantage in doing this, to do it. But without checking our results by the use of that method there seems, on the whole. to be a surprising lack of that fine degree of correlation in variation which we should expect to find existing, if we believe that the actual existing conditions of structure and pattern in these bilaterally symmetrical animals are an expression of the result of the action of a rigorous natural selection. If one condition of pattern or structure is the most advantageous (of the many conditions which selection among a host of fluctuating variations could have established), surely this condition ought to be pretty closely similar on both sides of the insect. That as much bilateral variety as actually exists, in many of the species examined by us, should exist-a variety comparable in certain cases even with the degree of variety revealed by the comparison of considerable series of individuals-is a state of affairs that only confirms us in the belief that these innumerable small continuous variations, on which for so long the thoroughgoing selectionists have put their faith as the sufficient bases for natural selection's species-forming work, are clearly not competent to serve as such bases. If these 'continuous' variations are the foundation stones of new species, some other agents than selection must be found or invoked to build several courses on them, to produce some cumulation of them, before natural selection finds them of that life-and-death worth which is the prerequisite for her potent interference."

${ }^{21}$ Henslow, the botanist, has maintained a constant attitude of antagonism to natural selection on the basis of his belief that the 
complex correlations of floral structures cannot possibly be accounted for by the natural selection of fortuitous variations. Henslow's Henslow's an observations and ideas are exploited in detail in tagonism to selec- two books called, "The Origin of Floral Structures tion as explain- through Insect and Other Agencies," I895, and er of floral corre- "The Origin of Plant Structures by Self-Adaptation lations. to the Environment," I 895.

${ }^{22}$ Wolff, G., "Beiträge zur Kritik der Darwin'schen Lehre," p. 6, 1898 .

${ }^{23}$ Wolff, G., "Beiträge zur Kritik der Darwin'schen Lehre," I8g8. I quote the following, pp. 6-8:

"Solche Erscheinungen, welche der Erklärung durch die Selektionstheorie widerstreben, weil sie hier eine gesetzmässige komplizierte Veränderung der Formen voraussetzen würde, Wolff's objection statt sie zu erklären, sind aber nicht etwa nur vereinto the necessary zelte Fälle, sondern von solchen wird die ganze assumption of identical and coincident variation in repeated structures as feathers, scales, etc. Formgestaltung beherrscht, wie z. B. von symmetrischer Anlage. Auch brauchen wir uns bei dieser Betrachtung nicht nur auf solche Gebilde zu beschränken, die in geringer Mehrheit vorhanden sind, sondern es giebt ja Gebilde, die in hundert-, ja tausendfacher Anzahl an einem und demselben Organismus sich finden, wie Schuppen, Haare, Federn. Betrachten wir z. B. gerade die Federn. Wie viel Millionen Variierungen musste eine Reptilienschuppe durchmachen, bis sie sich in eine Feder verwandelt hatte, vollends noch in ein so kompliziertes Gebilde wie z. B. die Schwanzfeder des Pfaues. Aber dies wäre immer noch nach der Selektionstheorie erklärlich. Nicht erklärlich dagegen wäre, dass die anderen Schwanzfedern immer gleichzeitig dieselben Variierungen durchmachten. Ein Gesetz, welches ein einheitliches Variieren dieser Hautgebilde vorschreibt, giebt es nicht. denn es variieren ja nicht alle gleich. Es entstehen viele gleiche Flaumfedern, viele gleiche Schwanzfedern etc., an einigen Stellen bleiben die Schuppen sogar erhalten, nämlich an den hinteren Extremitäten.

"Wir können noch weiter gehen. Eine Masse von einzelnen Zellen musste bei den verschiedenen Differenzierungen, bei Entstehung des Darms, des Nervensystems, der Muskulatur etc. in ganz genau der gleichen Weise variieren. Wenn wir hier die Selektionstheorie zur Erklärung herbeiziehen wollen, so ist die Kompliziertheit des einzelnen Variierungsinkrementes so gross, dass damit die ganze weitere Erklärung überflüssig wird.

"Interessant sind ferner solche homodynamen Gebilde, die nicht zu gleicher Zeit auftreten, wie der dritte halbzirkelförmige Kanal 
im Gehörorgan der Wirbeltiere, welcher bekanntlich erst in der Klasse der Fische auftritt. Dieser dritte Kanal ist den beiden andern völlig gleich, hat Crista, Ampulle, Macula etc., ist aber später entstanden; die nämlichen zufälligen Variferungen, die stattfanden bei der Entstehung der beiden ersten Kanäle, mussten viele Generationen später ganz genau in derselben Art sich wiederholen! Dass diese Variierungen wieder auftreten, dies erklärt die Darwinsche Lehre nicht; denn die Selektion kann ja keinen Einfluss auf die Variierung ausïben.

"Aehnlich sind die Resultate der Kowalevskyschen Untersuchungen über fossile Huftiere zu betrachten, welche sich auf die in Lauf der phylogenetischen Entwicklung stattgehabten Umwandlungen des Extremitätenskelettes dieser Tiere beziehen. Hier kann bekanntlich eine allmählich eintretende Verringerung der Anzahl der Metatarsal- und Metakarpalknochen sowie der Phalangen verfolgt werden. Diese Verringerung tritt zuerst an den hintern, erst später an den vordern Extremitäten auf!"

${ }^{24}$ A moth, Ploryganidia califomica, whose larvæ live abundantly on the oak trees in California, shows very clearly how a conspicuous

Example of mal- disadvantage does not seem to interfere much with adaptation in egg-successful life; for the "success" of this moth is only laying habit of too well proved by the serious injuries which it proPhryganidia cali- duces, because of its great numbers, on the beautiful fornica.

trees it infests. For several years the live-oaks and white oaks of the Santa Clara Valley were defoliated to a dangerous extent. The life history of the moth is told in detail in "The Californian Phryganidian," by Kellogg and Jack, Proc. Cal. Acad. Sci., Ser. 2, Vol. V, pp. 562-570, I895. From this account I quote the following: "Although most abundant on the live-oaks (Q.agrifolia), the larvæ attack other oaks. We have found them on Quercus lobata, $Q$. kelloggii, $Q$. dumosa, and $Q$. douglasii. The live-oaks in this vicinity begin to put out new leaves about January $I$, but in the case of many of the trees badly defoliated by the larvæ in the autumn, new leaves appeared much earlier than the first of January. The wintering of the insect in a larval condition is only possible in the evergreen oaks, and they are thus the natural and usual host of the pest. At the time of the hatching of the first of the autumn brood of eggs (latter part of November), the leaves of the deciduous oaks begin to fall. But, oddly, the eggs were found to be deposited on the leaves of both the white oak and Douglas's oak (deciduous oaks), and the larvæ hatched only to die of starvation. By this suicidal means the pest aids in depleting its own numbers. The new leaves of the deciduous oaks appear about April r. before the eggs for the summer brood of larvæ are deposited. These eggs, 
therefore, can safely be laid on the leaves of these trees, but the eggs laid by the fall moths on the foliage of these trees give up their young to certain destruction."

${ }^{25}$ Mivart, St. G., "On the Genesis of Species," I87I.

${ }^{26}$ Wolff, G., "Beiträge zur Kritik der Darwin'schen Lehre," p. 8 ff., I 1898 .

${ }^{27}$ In Piepers, M. C., "Mimikry, Selektion und Darwinismus," 1903, the author strongly antagonises the Darwinian explanation

Piepers's an- of protective warning and mimicking colour patterns. tagonism to selec-Piepers claims to show (I) that the so-called mimicry tion explanation is a phenomenon or appearance whose biological of colour and pat-value is greatly over-praised; (2) that the causes of tern of insects, this appearance are not entirely known, yet can in most cases be very well explained without having recourse to this natural selection theory; and (3) that, therefore, mimicry makes natural selection in no wise necessary, and hence lends no basis for its establishing. The author also, in a long discussion of nearly one hundred pages, criticises adversely the selection theories and Darwin in general. He holds that the Darwinian theory of speciesbuilding from varieties is very ill-grounded, but finds also de Vries's mutations-theory incompetent to explain species, at least, in the large degree in which they actually exist. The author presents a theory or explanation of his own for species-forming, which is essentially this: Variation is not simply a fluctuation about a stable mean; it is evolution in small steps. Evolution is the principle of life; it is determinate, i.e., progressive. yet with rapid, slow, or even standstill periods. There are differences in the rapidity of evolution among similar groups, as classes, orders, families, genera, species. races, even individuals, and the two sexes of a kind. This accounts for the great variety of life. There is a great variety of stages of evolution rather than a great variety of adaptation.

${ }^{28}$ De Vries, Hugo, "The Evidence of Evolution," Science, N. S., Vol. XX, pp. 395-401, 1904.

${ }^{28}$ Lankester, Prof. Ray, Address by, reported in the London Mail, September, rgo6.

${ }^{30}$ Ammon O., "Der Abänderungsspielraum," Naturew. Wochenschr., Vol. XI, pp. I37-I43. I49-155, I6I-166, I894.

${ }^{31}$ Bumpus, H. C., "The Variations and Mutations of the Introduced Sparrow, Passer domesticus," in Biological Lectures, Wood's Holl Laboratory, I897; also, "The Elimination of the Unfit as illustrated by the Introduced Sparrow, Passer domesticus," in Biological Lectures, Wood's Holl Laboratory, I899; also. "The Variations and Mutations of the Introduced Littorina," Zool. Bull., Vol. I, pp. 247259, 1898 . 


\section{CHAPTER IV.}

DARWINISM ATTACKED (CONTINUED): THE THEORY OF NATURAL SELECTION (CONTINUED).

Certain objections urged by various authors may be said to concern themselves more with the character of the varia-

objection based tions themselves and the possibilities of their on the linear and accumulation by selection, than with the manner non-qualitative of their occurrence. For example, de Vries ${ }^{1}$ character of fluc- denies the species-forming capacity of Dartions. winian selection of Darwinian (fluctuating) variation, on the ground that these variations are only "linear," and thus cannot afford a basis for the creation of new forms. Already existing bodies, organs, and parts can be enlarged or made smaller, made smoother or rougher, made bluer or less blue, greener or less green, that is developed plus-ward or minus-ward, but by this nothing really new is created. But, declares de Vries, the differentiation of organs consists, taken by and large, in the development of actually new characteristics; therefore in such material as that presented by the linear variations of Darwin, selection cannot have the necessary basis for this production of new characteristics.

Gustav Wolff " reiterates the same objection in his declaration that while the theory of natural selection may get on decently well when modifications embodying only quantitatic' changes in parts or organs are concerned, it is completely at a loss to account for modifications or adaptations requiring as basis qualitative changes. Even the warmest 
advocates of the selection theory have to admit, says Wolff, that they face a serious matter here. Weismann ${ }^{3}$ is quoted as follows: "Wenn man sich die Umwandlung deshalb in grösseren Schritten und durch Variationen von qualitativer Natur geschehend denkt, so wird man über dieses Hindernis nicht wegkommen. Ich glaube aber, dass man von den Variationen grösseren Betrages, wie sie bei domestizierten Tieren und Pflanzen nicht selten vorkommen, bei den Prozessen der Artumwandlung, wie sie in der freien Natur vor sich gehen, vollständig abgesehen hat, dass hier iiberhaupt nicht qualitative sondern mur quantitative Unterschiede der Individuen das Material der Naturzüchtung bilden, solche aber sind immer vorhanden." Wolff holds that there can simply be no doubt that if natural selection can do any modifying at all it has at most to limit itself solely to work possible on a basis of quantitative variation of already existing structures.

Variation also of whatever kind is subject to Galton's "law of regression. This is, put briefly, that the young of Galton's law parents varying from the mean of their species of regression. or race tend to vary also in the same direction but less so than the parent, so that the mean or mode among the young is nearer the species or race type (mean or mode) than the parental type was. Or as Morgan ${ }^{5}$ has stated it: "The facts of observation show that when a new variety appears its descendants are more likely, on the average, to produce proportionately more individuals that show the same variation, and some even that may go still farther in the same direction. If these latter are chosen to be the parents of the next generation, then once more the offspring may show the same advance; but little by little the advance slows down, until before long it may cease altogether. Unless, then, a new kind of variation appears, or a new standard of variation develops of a different kind, the result of selection of fluctuating variations has reached its limit. Our experi- 
ence seems, therefore, to teach us that selection of fluctuating variations leads us to only a certain point, and then stops in this direction. We get 110 evidence from the facts in favour of the view that the process, if carried on for a long time, could ever produce such great changes, or the kind of changes, as those seen in wild animals and plants."

There is something inherent in the make-up of the organism and something inevitably incident to the phenomena of variation which prohibit, even in the most favourable cases, the indefinite movement of variation. Johannsen, ${ }^{6}$ professor of plant physiology in the University of Copenhagen, finds that beans bred in pure lines, $i$. c., not crossed, conform perfectly with Galton's law of regression. And Johannsen holds that this regression must be a serious brake on the species-modifying, $i$. e., species-forming, activity of natural selection. That is, while the species mode can be moved in one direction or another by pure line breeding it can be so moved only very slowly. And this same law of regression will tend to break up a "mixed population" resulting from crossed and miscellaneous breeding into distinct pure lines; that is, each independent form-type tends to be constant, not constantly moving, $i$. e., transforming. New types must arise chiefly then through (a) the crossing of races or species (= hybridisation) or (b) through mutations.

Delage $^{7}$ in his criticism of selection makes the point that because the causes of variation are more feeble than the Delage's criti- causes of fixity (as evidenced by the massing of cism of Delbouf's variations around and close to the mean or mode, law.

and their increasing scarcity as they recede in any direction from the mode (species type)), the species tends always to stand still rather than to change. If in the first generation a thousandth of the individuals vary in the same way, in the second generation only I-IOOO of the thousandth part will show the same variation, reasons Delage. But, as pointed out in chapter vi ("Darwinism De- 
fended"), this criticism was long ago met by Delbœuf, who claimed to show mathematically that, however feeble may be the number of varying individuals compared with those non-varying, the number of the varying will always be increasing and will finish by being greater than that of the individuals holding to the type. Delage holds "Delbœuf's law" to be false as regards its attempted general application to the selection of variation, conceding it to hold true only in the hypothetical case where a persistent active modifying cause influences for some reason but a part of the individuals of a species. And Delage cannot conceive of a cause endowed with such an attribute.

An objection that has been often made to the natural selection theory may be put in the following general form:

Selection may It may be granted that selection can make evoluproduce evolution tion, i. e., adaptive change or progress, but this (continnous change), but not species (discon- tinuous chain or series. How is the chain tinnous series), broken into species? Are all our species simply the existent ends of series or chains? But we see many chains or series of discontinuous but obviously connected species. Natural selection can make erolution but not species. Darwin himself couched this objection more concisely as follows: "Why, if species have descended from other species by fine gradations, do we not everywhere see innumerable transitional forms? Why is not all nature in confusion, instead of the species being, as we see them, well defined?"

Professor Morgan, in his "Evolution and Adaptation," discusses this objection in the following paragraphs (pp. I29-I3I ) :

"The answer that Darwin gives [to his own just quoted query] is, that by competition the new form will crowd out its own less-improved parent form, and other less-favoured forms. But is this a sufficient or satisfactory answer? If 
we recall what Darwin has said on the advantage that those forms will have in which a great number of new variations appear to fit them to the great diversity of natural conditions, and if we recall the gradations that exist in external conditions, I think we shall find that Darwin's reply fails to give a satisfactory answer to the question.

"It is well known, and Darwin himself has commented on it, that the same species often remains constant under very diverse external conditions, both inorganic and organic. Hence I think the explanation fails, in so far as it is based on the accumulation by selection of small individual variations that are supposed to give the individuals some slight advantage under each set of external conditions. Darwin admits that 'this difficulty for a long time quite confounded me. But I think it can be in large part explained.' The first explanation that is offered is that areas now continuous may not have been so in the past. This may be true in places, but the great continents have had continuous areas for a long time, and Darwin frankly acknowledges that he 'will pass over this way of explaining the difficulty.' The second attempt is based on the supposed narrowness of the area, where two species, descended from a common parent, overlap. In this region the change is often very abrupt, and Darwin adds :

"To those who look at climate and the physical conditions of life as the all-important elements of distribution, these facts ought to cause surprise, as climate and height or depth graduate away insensibly. But when we bear in mind that almost every species, even in its metropolis, would increase immensely in numbers, were it not for other competing species; that nearly all either prey on or serve as prey for others; in short, that each organic being is either directly or indirectly related in the most important manner to other organic beings, - we see that the range of the inhabitants of any country by no means exclusively depends 
on insensibly changing physical conditions, but in a large part on the presence of other species, on which it lives, or by which it is destroyed, or with which it comes into competition; and as these species are already defined objects, not blending one into another by insensible gradations, the range of any one species, depending as it does on the range of others, will tend to be sharply defined.'

"Here we have a petitio principii. The sharp definition of species, that we started out to account for, is explained by the sharp definition of other species!

"A third part of the explanation is that, owing to the relative fewness of individuals at the confines of the range during the fluctuations of their enemies, or of their prey, or in the nature of the seasons, they would be extremely liable to utter extermination. If this were really the case, then new species themselves which, on the theory, are at first few in numbers ought to be exterminated. On the whole, then, it does not appear that Darwin has been very successful in his attempt to meet this objection to the theory."

A rather surprising objection is that of Pfeffer, ${ }^{8}$ who contends that selection cannot be the cause of the formation Pfeffer's objec- of species, for if it were real, however feeble Pfion based on the
tits effects, it would transform species much slowness of spe- more rapidly than they are transformed; and in
cies change.

order to transform a species in a long time the protection afforded by the selection of small additions or modifications is so feeble as to be illusory. And adequate protection under such a system of species transformation is imperative. This is a curious argument, for it has always been one of the claims of the mutationists that a "hurry"p" theory is needed in order to satisfy the familiar objection that the physicists' estimate of the actual age of the world is too low to admit of the production of the hosts of kinds of animals and plants which we know to have existed 
by the process of natural selection. But Pfeffer, who is an ingenious debater, makes out a very plausible case for his contention.

Of the many special questions that have been asked of the selectionists two may be mentioned, simply as examples illustrative of a rather formidable category of objections most of which are concerned with certain particular phases of evolution or groups of evolution phenomena rather than with the whole problem of species-forming. Many such special objections or questions touching specific cases were taken up and answered by Darwin in his "Origin of Species." Morgan has recently ("Evolution and Adaptation") gone over critically many of these special objections. and Darwin's answers to them, and pointed out clearly that in numerous cases Darwin relied for his answers on evolution factors which the neo-Darwinians have attempted to read out of court. In many tight places Darwin availed himself of the Lamarckian factor of the cumulation, through inheritance, of the effects of use and disuse, or of other functional stimuli originating either in internal or extrinsic conditions. That is, Darwin, while constantly trying to rely, and whenever possible relying on natural selection as the species-forming and adaptation-explaining cause, never hesitated, when it seemed necessary, to admit the influence and effect of the inheritance of acquired characters. or the influence of other, to him, unknown factors. In most cases of degeneration, for example, he adopted a Lamarckian explanation.

The question of how sterility between species could have arisen is a case in point. "That this property of species is useful to them in the somewhat unusual sense Difficulty of explaining inter. that it keeps them from freely mingling with species sterility other species is true," says Morgan; "but this by selecticn.

would be a rather peculiar kind of adaptation. If, however, it be claimed that this property is useful to 
species, as Darwin himself claims, then, as he also points out, it is a useful acquirement that cannot have arisen through natural selection. It is not difficult to show why this must be so. If two varieties were to some extent at the start less fertile, inter se, than with their own kind, the only way in which they could become more infertile through selection would be by selecting those individuals in each generation that are still more infertile, but the forms of this sort would, cx hypothese, become less numerous than the descendants of each species itself, which would, therefore, supplant the less fertile ones." Darwin admits that this situation cannot apparently be explained by natural selection, and simply says that to him it appears "that the sterility both of first crosses and of hybrids is simply incidental or dependent on unknown differences in their reproductive systems."

Wolff ${ }^{\circ}$ has urged strongly the objection that natural selection does not explain the degeneration or atrophy of parts,

Objection that selection cannot explain extreme and complete degeneration of parts. at least not large or nearly complete reduction. And Weismann and other selectionists long ago conceded that some sort of auxiliary principle was necessary to explain degeneration on a Darwinian basis. This principle was supplied by Weismann, under the name of panmixia, which is, simply, that a constantly active selection is necessary not only for the evolutionary development or specialisation of an organ but as well for its retention in specialised condition. ${ }^{10}{ }^{11}$ So that an organ which is no longer used and is therefore useless comes no longer under the supporting influence of selection (on the basis of advantage) and must consequently degenerate. But, as Wolff says, it seems obvious that such

- an influence or effect of the cessation of selection or of panmixia (so-called by Weismann because all variations good and bad alike mix and compensate each other) can at best lead to degeneration or atrophy only when the negative or reducing variations are in the majority, for when 
this is not the case the average of the survivors cannot change. Weismann himself has in recent years recognised the inadequacy of panmixia alone to explain degenerative phenomena. He says:" . . In most retrogressive processes actire selection in Darwin's sense plays no part, and advocates of the Lamarckian principle, as above remarked, have rightly denied that active selection, that is, the selection of individuals possessing the useless organ in its most reduced state, is sufficient to explain the process of degeneration. I, for my part, have never assumed this, and have on this very account enunciated the principle of panmiria. Now, although this, as I have still no reason for doubting, is a perfectly correct principle, which really does have an essential and indispensable share in the process of retrogression, still it is not alone sufficient for a full explanation of the phenomena. My opponents, in advancing this objection, were right, to the extent indicated, and as I expressly acknowledge, although they were unable to substitute anything positive in its stead or to render my explanation complete. The very fact of the cessation of control over the organ is sufficient to explain its degeneration, that is, its deterioriation, the disharmony of its parts, but not the fact which actually and always occurs where an organ has become useless-viz., its gradual and unceasing diminution continuing for thousands and thousands of years and culminating in its final and absolute effacement."

To supply the lack in the present neo-Darwinian explanation of retrogression Weismann calls on his new theory of germinal selection, the "rehabilitator of the natural selection theory" (for an account of this theory see chapter viii). But Wolff and Morgan and others have shown how unsatisfactory and inadequate this third attempt at an explanation is, even if we grant the actuality of germinal selection, a hypothesis which has by no means met with any general acceptance by biologists. 
In all our discussion of the effectiveness of the natural selection theory one feature of it has so far not been questioned. And that is the actual selecting power when the variations or differences among individuals are large enough to be conceivably of real advantage or disadvantage to the respective organisms. That is to say, we have not brought into question the alleged rigour of the struggle for existence upon which rigour depends, of course, the selection and the survival of the fittest. The very phrases "struggle for existence" and "survival of the fittest" presuppose and assume a rigour of competition and a life-and-death-determining value of the variations or differences that are fundamental features of the natural selection theory. Let us, however, not hesitate to scrutinise these basic assumptions of the Darwinians.

What of the actual rigour of the struggle that must be presupposed in order to give small variations a life-andScrntiny of the death-determining worth? Does it exist? Has. claimed extreme it been observed? Is the actual (admitted) rigour of the
straggle and the production of thousands or millions of eggs. consequent per- or embryos in localities capable of supportingscral selection.

but tens or hundreds of individuals, sufficient reason for deducing an endless, searching, utterly rigorous competition sufficient to give the slightest variations a weight in the balances determining death or life? In the first place, this tremendous competition must be largely over, if it exists, before the individuals come to maturity. Especially is this absolutely true of all species that live for a long time in immature stages and a very short time in the adult stage, as the Mayflies ${ }^{13}$ with only a nightlong adult life. Many insects of complete metamorphosis (i. $c_{\text {. }}$, those whose adult stage, assumed during a quiescent encased pupal stage, is very different from their larval stage) which have very elaborate structural specialisations in the adult stage have had their fate as offspring-producing 
agents decided for them in immature, $i$. e., egg, larval, or pupal, life, and this immature life is in most cases by far the larger part of the insect's duration of existence.

Henslow ${ }^{14}$ sowed together the same quantity of two kinds of wheat in a square yard of ground. The young wheat plants that came up were many times as many as the soil could support; the passive struggle for life was intense. In the end twenty heads ripened and these were all of one of the two kinds sown. The experiment was repeated in the following year with the same result. In the struggle one kind of wheat had a distinct advantage over the other. But this selection depended wholly on special characters or strength of the young stages. None of the adult characters cut any figure in this selection, which was decided before ever the plants came to maturity. And this is true, it seems to me, of most of struggle and selection.

It is not in the adult state that the oppressive abundance exists: in the forest to-day are about as many crows as last year; in the meadows as many yellow butterflies as in summers by. The eggs and the young are the stages which figure in mortality tables. They need the variations and adaptations; the pressure is largely gone before maturity is reached. However, the adaptations of the fully-developed body, in structure and function, certainly do not fall behind those of the embryonic and immature stages. Indeed they obviously are more complex and perfected.

But after all what determines just what millions of trout's Indiscriminate eggs shall be destroyed and what thousands death. shall hatch small fry? Many a sharp-eyed trout fisherman, many a keen-witted nature observer, many a trained. biologist will answer: Chiefly chance, the luck of position, the good fortune of not being devoured by the roaming things that paddle or crawl in the upper reaches of trout streams. What shall decide when the big whale opens his mouth in the midst of a shoal of myriads of tiny 
Copepods floating in the pelagic waters of the Aleutian seas, what Copepods shall disappear forever? Mainly, we may say, the chance of position. A bit more or less of size, or strength, or redness, or yellowness, or irritability or what not of form and function is going to avail little when the water rushes into the yawning throat. Now this chance and this luck are the luck and chance of the law of probabilities; that is, luck and chance capable of being mathematically determined. Given so much ocean, with so many whales swimming about in such and such curves at such and such rates and opening and closing their mouths intermittently at such and such intervals, and just so many shoals of so many million Copepods, these shoals at such and such distances apart, and any mathematical friend will reckon for you the chances any one Copepod individual has at any given moment of being swallowed. But Darwinian variations in the Copepod body will be represented by no function in the mathematician's formula. When the scores of little streams dry in California every summer, what determines whether millions of Californian water-insects of scores of kinds shall die in July or not? Mainly life or death is determined for them by their good or ill luck in being in one of the few streams that do not dry up, or in one of the many that do dry. Kelsey Creek runs into Clear Lake, in northern California; it is usually ever-living, but some summers it suddenly dries up. Fish play back and forth between this stream and the lake; at the time of the sudden drying a few hundreds of thousands out of many hundreds of thousands that habitually live in the stream and adjacent lake waters find themselves one awful day gasping painfully for water to wet their drying gills. They gasp a short while and then die. Did they all have the same number of scales, the same shape and size of body, the same tinges of fleeting colour? No, they represented most of the possible gamut of Darwinian variation for their particular 
species. But they were dead all together, by the ill-chance of position. In Lagunita, a small artificial lake on the campus of Stanford University, water pours in from two or three rivulets during the rainy season so as to fill it and make it an abiding place for many aquatic organisms that swim in or are washed in through the dikes. And thousands of little fishes and water beetles and dragon-fly nymphs and the like live contentedly there for seven or eight months. But with the rainless summer months come swift evaporation and steady leakage, and by September all the thousands of little fishes and insects lie dying there together in the last few puddles. It is the hard luck of a fatal chance against which all the variations in colour, in size, in scales, in spines, and what not are as one as far as helping or saving any of the gasping possessors is concerned.

One might go on tiresomely but one does not need to point the moral of these tales. Wolff ${ }^{15}$ has clearly fancied how the fate of millions of tapeworms may hang on the reception in the German Reichstag of a clever speech for or against meat laws. To go so far isn't necessary: the very life-history of the tapeworm and of hundreds of similarlylived vermian parasites shows to what nearly absolute degree chance rules their fate, and how utterly insignificant a part in it miscellaneous individual variation can possibly play.

But aside from the part that what we may call fortune ${ }^{16}$ of position plays in determining life or death among individuals, what of the actual rigour of the strugHow real is per- gle in those cases where death does not come to thousands at a moment; -in the whale's mouth, by catastrophe of flood or drouth, or by the elephant's tread on the ant-hill? To this question of the rigour of intra-specific struggle I have given some personal attention in insect life, and while to detail observations here would be impossible, I may say baldly that no such rigour of in- 
dividual selection based on variation ${ }^{17}$ in colour, in pattern, in venation and other wing characters, in hairs and in numerous other structural characters, as demanded by the needs of the selection theory, is to be detected. I find just as much variation represented in series of mature individuals collected miscellaneously after having lived for more or less time a free life exposed to all the dangers of this life, exposed, that is, to the rigour of the individual struggle for existence, as among series of similar extent of individuals of the same species collected just at the time of reaching maturity but before enjoying any opportunity to be weeded out (on a basis of disadvantageous variation) by the rigour of the life-struggle. Just as many varying individuals, with variations of just as much extent and variety, were found in series exposed to the struggle, in which these variations are presumably capable of saving or losing life, as among series not yet exposed; in other words, just as much variation exists after enduring the selective rigour of the struggle as existed on the day when the insects are first exposed to it.

Conn ${ }^{18}$ expresses his belief concerning destruction by chance and the rigour of the struggle as follows:

Conn's discus-

"Indiscriminate destruction occurs consion of the chances stantly, and certainly influences the problem of of death.

survival. Of the hundreds of individuals that are produced where few can live, many are destroyed indiscriminately, independent of the principle of survival of the fittest, and of these that are thus killed doubtless some are superior to those that survive. This principle of indiscriminate elimination does not in the slightest deny the force of the principle of survival of the fittest, but only indicates that its action is not absolutely rigid. The fittest do not always survive, for many of them are destroyed.

"On the other hand the least fit do not always perish. Whether an individual shall live or die in the struggle is 
largely a matter of accident. Many a well-equipped individual will die, while many another, even though handicapped by decidedly unfavourable characters, will continue to live and produce offspring because of some specially favourable conditions. Nothing could seem to be more decidedly disadvantageous than a broken leg, and, if the principle of elinination of the unfit were rigid, broken-legged individuals should be speedily destroyed. But it is quite common to find animals with broken legs or arms which yet succeed in living perfectly well. They have repaired their broken members by processes of bone growth, and have been able to carry on their part in the struggle for life and survive competition. I have found a frog with the whole of both feet bitten off, and yet with the wounds healed, the animal living without feet, and hence hardly able to swim, but side by side in competition with other well-developed animals. I have found a clam that in its young condition had received a severe rent in one gill, through which, by some twist the body had been thrust, giving rise to the extraordinary condition of three gills on one side of the body and one on the other, a truly monstrous abnormity. But this clam had lived to maturity and produced eggs in quantities equal to any other clam.

"Now such instances simply show the complexity of the conditions which determine survival. They indicate that these animals were favoured in some respects sufficiently to counteract the disadvantage of their mutilations. But the fact that so many instances are found does show that single characters do not always determine survival or elimination. The question whether an individual survive is dependent upon many factors, of which utility of various organs may be one and accident another. What would seem more sure from a logical standpoint, than that, in the intense struggle for life due to numerous individuals seeking for food, a frog who was unable to swim because of the loss of his 
feet would be sure to be a loser? Even if the inflammation caused by the wound did not destroy him, it would seem impossible for the animal to obtain his share of food. Of course, a footless race would be eliminated in a comparatively short time, but the survival of so many mutilated individuals shows that selection is not so rigid as to eliminate all unfit individuals, even though their disadvantage be very great.

"If a very disadvantageous character may thus fail to produce destruction it must be still more true that a favourable character, occurring in a single individual, has really little chance for survival. The individual possessing it will have to compete with accident, with indiscriminate slaughter, and with other conditions which we have just seen may be sufficient to preserve even a broken-legged individual. Nothing can seem more evident than that the web of the foot and the muscles of the legs are of use in swimming, and have therefore been developed by the preserving influence of natural selection. If anything is of selective value, these characters certainly are. But when we find that a frog with no fect can survive the struggle for existence, it is evidently difficult to believe that single variations, either of use or disadvantage, will have any special likelihood of surviving at the expense of other members of the race, so as eventually to replace all others. But only thus can they be 'seized upon by natural selection and preserved.'

There are two important objections to the natural selection theory based on the relations of this theory with the Natral selec- two other selection theories, namely sexual tion needs the selection and artificial selection. Wolff ${ }^{19}$ has support of the made the criticism that natural selection must
sexual selection theory, which is be supported by the sexual selection theory discredited.

in order to stand. It makes no pretension of explaining those extraordinary secondary sexual characters such as ornamentation, songs, dances, odours, etc., which 
not only are of no conceivable utility in the struggle for existence but are in many cases of obvious disadvantage. It relies wholly on sexual selection to explain them, and yet in Wolff's eyes, and indeed in the eyes of most biologists, sexual selection is practically discredited. It certainly cannot explain some or many of these characters. (See account of the sexual selection theory and the criticisms of it in the next chapter.) Therefore, say Wolff and other antiDarwinians, natural selection is undermined in just so far as it relies on the sexual selection theory to sustain it.

The other objection is that the natural selection theory rests altogether too largely on an unwarranted analogy with Natural selec- the phenomena of artifcial selection. Plate ${ }^{20}$ tion rests too has graphicaily expressed the contrast between analogy with arti- the facts and processes of the two kinds of ficial selection. selection in the following double-column table:

ARTIFICIAL SELECTION.

(I) rests on the wish (Willen) and intelligence of the breeder, except in a certain few cases of "unintentional breeding" (See Darwin, "Origin of Species.")

(2) selects exceptional, most widely divergent characters, which appear only in a few individuals.

(3) complete isolation (pure breeding) of the selected individuals.

(4) often leads to exaggerated development and to a sickly disposition, so that the whole constitution suffers.

(5) leads comparatively rapidly to new forms.

(6) The artificially-produced
NATURAL SELECTION.

(I) rests on the unvolitional and unreasoning resultant of natural forces.

(2) is a selection of slight differences, appearing simultaneously in many individuals.

(3) pure breeding is often very difficult through the possibility of crossing with the parental type.

(4) effects no injury to the whole constitution, but on the contrary a strengthening and bettering of it.

(5) The modification of species is effected, presumably almost always, very slowly, for if it were otherwise the appearance of new species would be often observed.

(6) The natural races (varie- 
races are unstable; they revert easily to the ancestral type if allowed to run wild; this is so probably because of their recent origin.

(7) The artificially-produced races of the same species are in most cases fertile among themselves. ties) are stable; they do not revert if the outer conditions (environment) remain constant; this is so probably because they are more firmly established by reason of greater age.

(7) Natural varieties do not cross in nature, either with each other or with the ancestral type.

The most important contrast between the two kinds of selection lies, in my eyes at least, in the results obtained in the character of the new forms. As Morgan ${ }^{21}$ well says, "we should not lose sight of the fact that even after the most rigorous selective process has been brought to bear on organisms, namely, by isolation under domestication, we do not apparently find ourselves gradually approaching nearer and nearer to the formation of new species, but we find, on the contrary, that we have produced something quite different. In the light of this truth, the relation between the two selective theories may appear quite different from the interpretation that Darwin gives of it. We may well doubt whether nature does select so much better than does man, and whether she has ever made new species in this way."

De Vries expresses very positively his belief that no artificial races are fixed and constant forms, in the sense that natural varieties are. And this difference he believes to rest on the radically different method ${ }^{22}$ of origin of the two kinds of forms; the domestic ones through carefully maintained selection; the natural ones through definitive immediately fixed and enduring mutations.

If one stops to recall his own familiar knowledge of the cultivated plants ${ }^{23}$ and will roughly classify the cultivated fruits and vegetables and ornamental plants with which he is acquainted into two categories depending upon the mode of reproduction, that is whether by division or by seeds, one will be struck by the great preponderance of the first of the 
two categories, - the category, namely, of cultivated plant races which are reproduced practically exclusively by division (i. $\mathcal{c}$., by cuttings, roots, scions, buds, etc.). The reason for relying upon this kind of reproduction is, in nearly every case, that these races do not breed true to seed, $i$. e., the races are not fixed, are unstable. And even among those races which we are accustomed to allow to reproduce by seed how necessary it is to maintain the unusual environment, the exaggerated excellence of conditions of food supply, humidity, protection from natural enemies, etc., if we are to be successful in maintaining the parental characters of the plant. Let a few individuals escape from the hothouse or fertilised and sprinkled garden and see how soon, if they can persist at all, they lose their characters of amelioration, and become most pitifully unadorned.

In Pfeffer's ${ }^{24}$ eyes the fundamental difference between -the two selection processes rests on the fact that the breeder or plant ameliorator selects his individuals (the "to be saved") on the basis of the character or condition of single characteristics, while in nature survival is not determined by such conditions, but on a basis of total or all-around fitness or advantage. "The moment," says Pfeffer, "that one believes one's self to be able to place in parallel, simply and directly and in general, the activity of the breeder and the activity of the struggle for existence, and from this false generalisation deductively to compare the selective work of the breeder based on definitive special characters with the automatic selective work of nature based on similar specific characteristics, that moment one enters the camp of the teleologists, whether he is doing it knowingly and willingly, or not. In short it is a logical fallacy when one assumes to substitute for the selective action of the breeder a mechanically-working natural selection. Only in a single kind of case has this position any justification, and this not on account of logical correctness but on account of the pecu- 
liar identity of the circumstances. And this is when a single definitive characteristic is so all-important and dominant in the life of a race or species that its presence really has a life-and-death-determining value in the struggle for existence; in this case the killing out of all the individuals not prozided with this specific character has the same result as an actual selection of the possessors of this character. The farther, however, the actual circumstances differ from this case, in so far as a number of characteristics, and not a single one, determines the outcome of survival, by just so mich less can the Darwinian explanation be made to cover the situation."

De Vries sums up a full and careful discussion ${ }^{25}$ of natural as compared with artificial selection as follows: "In conclusion, summing up all our arguments we may state that there is a broad analogy between breeding-selection in the widest sense of the word, including variety-testing, raceimprovement, and the trial of the breeding ability on one side, and natural selection on the other. This analogy, however, points to the importance of the selection between elementary species, and the very subordinate rôle of intra-specific selection in nature. It strongly supports our view of the origin of species by mutation instead of continuous selection. Or to put it in the terms chosen lately by Mr. Arthur Harris in a friendly criticism of my views: 'Natural selection may explain the survival of the fittest, but it cannot explain the arrival of the fittest."

Finally I desire to add an objection that has real weight with me, whatever may be the personal attitude of other

An ircreasing naturalists or students to it. And that is, that ing biologists a constantly increasing number of working unsatisfed with biologists find themselves, on a basis of their
the selection theories. cumulative individual observation and experience and thought, unsatisfied with the explanation of adaptation and species-forming offered by the selection theories. 
Men using, or rather, testing, these theories every day in their work in field and laboratory, find selection insufficient to explain the conditions that their observation and experiments reveal to them. These men are students in all the different lines of biological work; they are zoologists, botanists, palæontologists; they are students of anatomy, physiology, œcology, and taxomony (classification); they are embryologists, pathologists, animal and plant breeders. From all these lines of work come increasing complaints; selection cannot explain for me what I see to exist. From some the cry is more bitter: selection is a delusion and false guide; I reject it utterly. For me, I repeat, this is an objection of much significance and importance. Just as modern chemistry seems to be finding its long useful atonic theory now a restraint and a hindrance in understanding the wonderful new facts that have followed the pushing out of investigation into the rich fields of physical chemistry, so the biological experimentalists, the students of variation and heredity, of life mechanics, of physico-chemical biology, are finding the rigid theory of selection's control of all processes and phenomena a rack on which they will no longer be bound.

Coupled with the significance of this general objection to the reign of the selection theory-a general objection that The concessions the selectionists will say is simply the objection of the selection- that the selection theory is objected to-is the ists.

added significance of the concessions in the way of supporting theories that the neo-Darwinians have made to the general increase and sharpness of scientific criticism of selection; conspicuous examples are Roux's theory of the battle of the parts, and Weismann's theory of germinal selection. This latter is no less than a neo-Darwinian explanation of how determinate variation, that is orthogenesis, may be explained non-teleologically. Which is practically to rob natural selection of all influence in the 
primary determination of lines of descent. But to these supporting and concessionary theories we shall come in a later chapter.

To show how definitive and positive an anti-Darwinian position is taken by some biologists I shall quote some paraKorschinsky's graphs from an interesting short paper by Korradical anti-se- schinsky, ${ }^{26}$ a Russian botanist whose formulalection position. tion of the theory of species-forming by heterogenesis preceded that of de Vries by two years. In this paper (which is a vorläufige Mitteilung published in German preliminary to the issuance, in the publications of the Royal Academy of Sciences of St. Petersburg, of a larger, more detailed paper) Korschinsky arranges in parallel columns the various corresponding or contrasting items of the selection theory compared with the heterogenesis theory of the author himself (for this full table see chapter xi). From this table I quote only the following statements to show how differently from the Darwinian view the probable effects of the struggle for existence may appear to another naturalist and to what radically anti-Darwinian conclusions a man may come who interprets the effects of selection in this way:

"The origin of new forms can only occur under conditions favourable for them, and the more favourable such conditions are, that is, the less severe the struggle for existence is, the more energetic is their development. Under severe external conditions new forms do not arise, or if they appear they are extinguished.

"The struggle for existence, and the selection which goes hand in hand with it, compose a factor which restricts newappearing forms and restrains wider variations, and which is in no way favourable to the production of new forms. It is indeed an inimical factor in evolution.

"Were there no struggle for existence, then there would be no extinguishing of arising or already arisen forms. The 
organic world could then develop into a mighty tree, whose branches could all remain in blooming condition, so that the now isolated extremest species would be united with all others through gradatory forms.

"The adaptation resulting from the effects of the struggle for existence is absolutely not identical with advance, for higher-standing, more complex forms are by no means always better adapted to outer conditions than the lower ones. The evolution [used here by the author as synonymous with advance or progressive complexity] of organisms cannot be explained in a purely mechanical way. In order to explain the origin of higher forms from lower it is necessary to postulate in the organisms a special tendency to advance which is nearly related to or identical with the tendency to vary, which tendency compels the organisms to advance so far as the outer conditions permit."

These declarations sound strange and perhaps almost absurd in the ears of one accustomed for years to hear only the Darwinian interpretation of the effects of the struggle for existence and natural selection. But taken up one by one, as they are by Korschinsky, and developed and explained, they begin to have a kind of plausibility, an appeal to our reason, of much that sort which the Darwinian interpretation has and makes. After all the Darwinian interpretation is proved only in so far as it possesses a high degree of plansibility and makes a convincing appeal to our reason. Of exact proof, in the nature of observed fact or result of experiment, or of mathematical demonstration, there is little in the case either of the Darwinian or the Korschinskian interpretation.

Those other biologists ${ }^{27}$ who, like Korschinsky, take the extreme and positive stand that the struggle and selection are not factors in evolution, or if factors are really hindering and opposing ones, constitute, however, by far the smaller body in the ranks of the anti-Darwinian critics when 
compared with those whose arraignment of selection is chiefly a protest against its assumption of altogether an undue share of influence in species-forming, and whose principal attempt is to reduce selection to a secondary place among evolutionary factors, giving first place to that influence or those influences which determine the character and direction of variation. Still the totally anti-Darwinian critics are not few, and are not without ingenuity and capacity in debate.

But better justified by what we know to-day and far saner in their estimate of the Darwinian factors are such critics as Delage and Morgan. "The conclusion of Delage's esti-
ate of selection, detailed critical discussion of the "true rôle of selection," "is that selection is powerless to form species. Its rôle, however, is not mul, but it is limited to the suippression of variations radically bad, and to the maintaining of the species in its normal character. Far from being an instrument for the evolution of species it guarantees their fixity." And elsewhere he says: "Species come from fixed variations. The formation of species is due ordinarily to general variation [a conception of change much like that of de Vries's mutations and sudden fixed origin of elementary species], very rarely to strong individual variation [sports or discontinuous variations], and never to weak individual variation [fluctuating or Darwinian variation].

Morgan ${ }^{29}$ in a recent popular essay in which he takes a strong stand against natural selection as a species-forming Morgan's ad- factor and in favour of "definite variations" verse criticism of (de Vriesian mutations) concludes as follows: the species-form- "In the preceding pages I have tried to bring
ing value of $s \theta-$ lection. into contrast the point of view of the Darwinian school and the newer conception of the survival of elementary species. I have tried to show what selection has meant to the selectionists. They have 
never hesitated to take each particular character of an animal or plant, and dress it up in more perfect garments, while the body of the species, if I may so speak, has been left as it was before. There has been a continual tampering with the characters of the organism with the laudable intention of doing with them that which nature herself seems unable to do, namely, to dissociate them from the rest of the organisation and perfect them in this way or in that. It is this meddling with the fluctuating characters of the species that has been the characteristic procedure of the Darwinians, in their attempt to show how new species have been created. In contrast to this method, the theory of the survival of species assumes that a form once made does not have its individual parts later dissociated and adjusted to better fit the external needs of the species. Such a new form can change only by becoming again a new species with a new combination of characters; some of which may be more developed in one direction than before, others less, etc.

"New forms on the Darwinian theory are supposed to be created by a process of picking out of individual differences. If, in addition to this, Darwin supposed that at times varieties and species crowd each other out nothing new is thereby created.* On the other hand the theory of the survival of definite variations refers the creation of new forms to an-

* "If the survival of certain species determines, in a metaphorical sense, the kinds of future mutations that occur, the course of evolution may appear to be guided by selection or survival; but, however true it may be that selection acts by lopping off certain branches, and limits to this extent the kinds of possible future mutations, the origin of the new forms remains still a different question from the question of the survival of certain species. This negative action of selection is not the process that most Darwinians have had in mind as the source of the origin of new species. It is true that Weismann believes that selection of individual differences determines the origin of new species. and that the creation of these new species determines the future course of variations in the same direction, but his argument that fluctuating variations can go on indefi- 
other process, namely, to a sudden change in the character of the germ. The creating has already taken place before the question of the survival of the new form comes up. After the new form has appeared the question of its persistence will depend on whether it can get a foothold. The result is now the same as when species crowd each other out. This distinction appears to me to be not a matter of secondary interest, but one of fundamental importance, for it involves the whole question of the 'origin of species.' So far as a phrase may sum up the difference, it appears that new species are born; they are not made by Darwinian methods, and the theory of natural selection has nothing to do with the origin of species, but with the survival of already formed species. Not selection of the fittest individuals, but the survival of the sufficiently fit species.

"There is a fundamental difference between the idea that fluctuating variations become specific characters through accumulation by selection, and the idea that new species arise as definite variations, which, with their appearance, characterise the new form as a new species. According to the Darwinian theory, natural selection performs a double duty, first, to build up new species, and second, to maintain them in competition with other species. According to the other view, species are not formed by any kind of selection, and the question of survival only concerns the maintenance of species already formed. The primary problem is the problem of the 'origin of species.' The central idea is not

nitely varying in the direction of selection is refuted by what has. been actually found to be the case when the process of selection of fluctuating variations is carried out. Most of the individuals of a species may be brought in this way to show the particular character selected in its highest degree as a fluctuating variation, but it appears not possible to transgress this limit; and rigorous selection in every generation is necessary to hold the individuals to the highest point reached. Only by the appearance of new definite variations can a given character be permanently fixed. or a new species created that will show fluctuating variations around the new standard. 
what species survive, but how species originate; no matter whether they are going to become victorious or not.

"After a species has appeared it will surely be admitted by every one, that forms that can survive will survive! If Darwin's theory meant only this to those who adopted it, is it not surprising that such a truism should have been hailed as a great discovery? Was not the theory heralded because it seemed to explain how new species arose? What shall we say then when we find a situation like that existing at the present time, when we are told that after all the only difference between Darwin's theory of natural selection and the theory of the survival of definite variations is that in the one case fluctuating variations are selected, and in the other mutations, and that in both cases natural selection is the key to the evolutionary process! Is not the 'origin of species' still the real point at issue?

"I yield to no one in admiration for what Darwin has done in behalf of the biological sciences, for he succeeded, where the great French zoologists failed, in establishing the principle of evolution. Furthermore no other hypothesis, that has as yet been proposed, accounts so well for the widespread occurrence of adaptation of organisms to the environment as does the principle of natural selection. But appreciation of Darwin's claims in these directions need not blind us to the insufficiency of the theory of natural selection to account for the origin of species; nor to the fact that his followers have been especially concerned in propounding and making application of this side of the theory. They have shown little interest in selection as the great conserving factor of evolution, and the reason for this is not far to seek, because of the much greater importance that they have attributed to natural selection as a creative factor in building up individual differences into specific characters." 


\section{APPENDIX.}

${ }^{1}$ De Vries, H., "Die Mutationstheorie." Vol. I, pp. 83 ff., I90I.

"Wolff, Gustav, "Der gegenwärtige Stand des Darwinismus," p. 9. 1896.

"Weismann, A.. "Aufsätze über Vererbung," p. II6, I892.

"Galton, Francis, "Natural Inheritance." I quote from Galton as follows :

"As soon as the character of the problem of filial descent had become well understood, it was seen that a general equation of Galton's state- the same form as that by which it was expressed, ment of the law also expressed the connection between kinsmen in of regression, every degree. The unexpected law of universal regression became a theoretical necessity, and on appealing to facts, its existence was found to be conspicuous. If the word "peculiarity" be used to signify the difference between the amount of any faculty possessed by a man and the average of that possessed by the population at large, then the law of regression may be described as follows: Every peculiarity in a man is shared by his kinsmen, but on the average in a less degree. It is reduced to a definite fraction of its amount quite independently of what its amount might be. The fraction differs in different orders of kin. becoming smaller as they are more remote. When the kinship is so distant that its effects are not worth taking into account, the peculiarity of the man, however remarkable it may have been, is reduced to zero in his kinsmen. This apparent paradox is fundamentally due to the greater frequency of mediocre deviations than of extreme ones, occurring between limits separated by equal widths" (pp. I94-195).

"The law of regression in respect to stature may be phrased as follows: namely, that the deviation of the sons from $\mathrm{P}$ are on the average equal to one-third of the deviation of parent from $P$, and in the same direction or more briefly still: if $\mathrm{P}+( \pm \mathrm{D})$ be the stature of a parent, the stature of the offspring will on the average be $\mathrm{P}+( \pm \mathrm{I}-3 \mathrm{D})$ " (p. I04).

"Thus, however paradoxical it may appear at first sight, it is theoretically a necessary fact, and one that is clearly confirmed by observation, that the stature of the adult offspring must, on the whole, be more mediocre than the stature of their parents; that is to say, more near to the M of the general population" (p. 95).

"The law of regression tells heavily against the full hereditary" transmission of any gift. Only a few of many children would be likely to differ from mediocrity so widely as their mid-parent, and still fewer would differ as widely as the more exceptional of 
the two parents. The more bountifully the parent is gifted by Nature, the more rare will be his good fortune if he begets a son who is as richly endowed as himself, and still more so if he has a son who is endowed yet more largely" (p. I06).

"Morgan, T. H., "Evolution and Adaptation," p. 104, 1903.

'Johannsen, W., "Über Erblichkeit in Populationen und in reinen Linien," 1903.

`Delage, Yves, "L’Hérédité," 2 d ed., p. 398, 1903.

${ }^{8}$ Pfeffer, G., "Die Umwandlung der Arten," p. 26, I894.

'Wolff, G., "Beiträge zur Kritik der Darwin'schen Lehre," pp. 5o ff. I quote as follows:

"Für jeden, der sich den Grundgedanken der Selektionstheorie auch nur einigermassen klar gemacht hat, kann kein Zweifel darüWolff's criticism ber bestehen, dass die natürliche Selektion immer of panmixian nur ein einziges Anpassungsgebilde, niemals aber zwei oder gar noch mehr zu gleicher Zeit züchten kann. Es können z. B. Auge und Ohr nicht gleichzeitig gezüchtet werden, denn sonst müssten ja die ausgelesenen Individuen mit den besten Augen zugleich auch diejenigen mit den besten Ohren sein, eine Voraussetzung, die wir um so weniger machen dürfen, als dieselbe ja auf alle übrigen Organe ausgedehnt werden müsste. Die Naturzüchtung wird sich immer auf die Züchtung desjenigen Organes verlegen, dessen bessere Ausbildung für das Tier den grösseren Vortei] bietet. $^{1}$ Ist ein gutes Auge nützlicher, als ein gutes Ohr, so sind die Individuen mit den besten Aligen denen mit den besten Ohren gegenüber in Vorteil: sie werden gezüchtet. Während also das Auge gezüchtet wird, steht das Ohr nicht unter dem Einfluss der Selektion, also unter dem Einfluss der Panmixie. Unter diesem Einflusse stehen aber sämtliche Organe mit Ausnahme des einzigen, welches gerade gezüchtet wird, sie fangen daher alle an. einen Rückbildungsprozess einzugehen. Sobald nun eines der nicht gezüchteten Organe bereits so weit rückgebildet ist, dass der $Z_{\mathfrak{t}-}$ stand desselben eine Gefahr für den Organismus in sich schliesst, alsdann wird sich die Naturzüchtung diesem Organe zuwenden, denn dann ist eine bessere Ausbildung dieses Organes ein grösserer Vorteil als die des andern. Die Selektion überlässt also dieses letztere seinem Schicksal, d. h. der rückbildenden Panmixie, unter deren Einflusse die andern Organe immer noch stehen.

${ }^{1}$ Jedes Gebilde, welches durch Naturzüchtung hervorgebracht ist, auch wenn es jetzt von untergeordneter Bedeutung ist, muss einmal Generationen hindurch. d. h. so lange als die Selektion zu seiner Herstellung brauchte, das allerwichtigste gewesen sein, eine Konsequenz, die allein genügt, den ganzen Darwinismus ad absurdum zu führen. 
"Wem die Absurdität dieser ganz unvermeidlichen Konsequenzen noch nicht einleuchtet, der möge sich die Sache an einem Bilde versinnlichen. Wenn ein Lehrer eine Klasse von Schülern zu unterrichten hat und dabei so verfährt, dass er immer einen Schüler zu sich auf sein Zimmer nimmt und dort unterrichtet, unterdessen aber die übrigen treiben lässt, was sie wollen, so wird er bei einer Inspizierung durch den Schulrat mit seiner Klasse wenig Staat machen können. weil die Schüler weit mehr Zeit auf das Vergessen, als auf das Behalten und Lernen verwendet haben. Sie werden daher nicht nur das, was sie bei diesem Lehrer in den wenigen Einzellektionen, sondern auch das, was sie in den frühern Klassen gelernt hatten, vergessen haben. Genau so beim Organismus. Alle Organe stehen eine weit längere Zeit unter dem Einflusse der Panmixie, als unter den der Selektion; wenn also die Panmixie einen Einfluss ausübt, so wird dieser Einfluss der überwiegende sein, und wenn dieser Einfluss dem der Selektion entgegengesetzt ist, so wird der Einfluss der Selektion gänzlich aufgehoben werden, d. h. der rückbildende Einfluss würde die Oberhand behalten, das ganze Tier müsste sich mit Stumpf und Stiel-zurückbilden, ein Vorgang, bei welchem die Panmixie zu vergleichen wäre einem Feuer, das ein Dorf ergriffen hat, die Selektion dagegen einer Feuerwehr, welche mit der Spritze immer wieder an dasjenige Haus fährt, aus dem gerade die stärhsten Flammen herausschlagen. Diese Feuerwehr wird gewiss nicht viel von dem Dorfe retten.

"Der Darwinismus muss also, wenn er der Absurdität dieser Konsequenzen entgehen will, notwendig annehmen, dass diejenigen Organe, welche jeweilig nicht unter dem Einflusse der Selektion stehen, ruhig und unbeschadet warten können, bis die mütterliche Sorgfalt der Selektion. welche sich immer nur einem ihrer Kinder widmen kann, sich ihrer wieder annimmt. Das heisst der Darwinismus muss annehmen, dass die Panmixie keinen Einfluss auf die Organisation hat.

"Da aber die Variierung eine Thatsache ist, so muss er annehmen, dass günstige und ungünstige Variierung die gleiche ${ }^{1}$ Wahrscheinlichkeit haben, womit ein weiterer Beweis geliefert ist, dass der Darwinismus nur mit graduellen Veränderungen rechnen kann.

"Die Lehre von der Panmixie und die Selektionstheorie vertragen sich nicht mit einander. Aus der Richtigkeit der einen folgt die Falschheit der andern. Und insofern die Selektionstheorie eigentlich die Voraussetzung zur Lehre von der Panmixie ist, vernichtet diese letztere sich selbst durch ihre blosse Existenz. Ihre Bejahung

${ }^{1}$ Ist man, wie Emery, der Ansicht, dass ungünstige Variierungen grössere Wahrscheinlichkeit haben als günstige. so muss man hieraus allein die Unrichtigkeit der Selektionstheorie folgern. 
schliesst ihre Verneinung in sich, d. h. sie leidet an einem unlösbaren inneren Widerspruch."

${ }^{10}$ This necessity of constantly active selection must apply as well to specialised function as to specialised organ. But it is not diffiExample of inef-cult to call attention to certain functions or physiofective panmixia, logical capacities of various animals which seem to negative this declaration of the need of constant selection to maintain specialisation. For example, I have shown ("Regeneration in Larval Legs of Silkworms," Jour. Exper. Zool., Vol. I, pp. 593-599, Io figs.. 1904) that the long "domesticated" mulberry silkworm larva possesses the capacity of regenerating any of its legs, if the mutilation has not removed the whole appendage. Now the assumption of most selectionists is that this capacity for regenerating injured legs and other parts is a specialisation, adaptive and advantageous. But in connection with this particular case, it should be borne in mind that the silkworm has been for approximately 5,000 years a domesticated animal, cared for under such conditions as to make the natural loss of legs almost an impossible occurrence. Perfectly protected against such natural enemies as bite off legs, there has certainly been nothing of that sharp necessity, during all the life of countless generations of silkworms, which is supposed to be the basis for maintaining the advantageous capacity for regeneration. There has been a clear field for panmixia. But the regenerative capacity still exists in effective degree.

${ }^{11}$ See a recent paper by Vejdovsky ("Über einige SüsswasserAmphipoden, III, Die Augenredüktion bei einem neuen Gam-

Example of pro-mariden aus Irland und über Niphargus caspary gressive degener- Pratz aus den Brunnen von München," in S. B. Kgl. ation not expli- Böle by natural Böm. Ges. d. Wiss., 1905), embodying the results of selection. his studies on the reduction of the size in certain small Crustaceans (Gammaridæ), which he found living in the Irish Sea at a depth of from I30 to I50 feet. These Crustaceans form an interesting series showing a gradual reduction of the eyes. It is shown clearly that this reduction proceeds very regularly from the periphery toward the interior. First, there is apparent a high degree of variability of all parts, then the optic parts of the eye disappear, and finally the nervous, or retinal, parts. This course of reduction is only explicable, according to the author, on a basis of the inherited degenerative results of a lack of use, for in any decreasing lise exactly this course of individual degeneration of the eye is what is met with; that is, the active external optic elements degenerate first. and later the nervous, or retinal, elements.

${ }^{12}$ Weismann, A., "On Germinal Selection as a Source of Definite Variation," trans. McCormack, pp. 38 ff., 1896. 
${ }^{13}$ The Mayflies, or lake-flies, constitute an order (Ephemerida) of insects which spend from several months to perhaps a couple of years in their immature life (as crawling, gill-bearing, wingless aquatic larvæ), and from a few hours to at most a few days as free-flying adult creatures. Many other insects (indeed most insects) have a much shorter adult life than immature life, and most of them have very different structures in the two life-periods. Hundreds of insect kinds take no food in the adult stage and many others that do have food-habits quite different from the larval habits.

${ }^{14}$ Henslow, G. W., "Origin of Flowering Structures," 1895.

${ }^{15}$ Wolff, G., "Beiträge zur Kritik der Darwin'schen Lehre," pp. 4I, ff., I 898 . I quote as follows:

"Wäre die Wahrscheinlichkeit einer nützlichen Variierung wirklich so klein, wie Emery behauptet, wäre sie wirklich so klein, wie

Wolff's discus- die Wahrscheinlichkeit, dass in dem Satz einer sion of the selec- Druckseite durch beliebiges Ersetzen eines beliebigen tion coefficient. Buchstaben durch einen beliebigen andern ein Druckfehler verbessert wird, dann könnte sich der Darwinismus gleich von vornherein begraben lassen. Er könnte dann nicht mehr sagen: die Auslese des Bessern muss notwendig eine Steigerung des. Nützlichen ergeben. Die erforderlichen Voraussetzungen wären dann noch viel verwickelter; es müsste dann auch noch über den Intensitätsgrad ${ }^{1}$ des Selektionsprozesses eine Voraussetzung gemacht werden: er muss so hoch sein, dass die Summe aller überlebenden $\pm \mathrm{dx}^{2}$ (unter denen vor Eintritt des Selektionsprozesses die ungeheure Mehrzahl negativ, das Vorhandensein positiver dagegen äusserst unwahrscheinlich war) eine positive Zahl wird. Der Kampf ums Dasein an und für sich nützt also noch gar nichts; erst wenn er jenen ganz bestimmten Intensitätsgrad erreicht, dann erst wirkt die Selektion verbessernd. Und wie hoch ist dieser von

${ }^{1}$ Dieser Intensitätsgrad ist eine genau bestimmte. wenn auch selten bestimmbare Zahl. Sie giebt das Verhältnis der erzeugten zu den sich fortpflanzenden Nachkommen an. Man könnte diese Verhältniszahl den Selektionskoeffizienten nennen.

${ }^{2}$ Ich muss trotz der Einwendungen Emerys meine Schreibweise $\mathrm{dx}$ beibehalten. Sage ich, dass der Darwinismus mit dem Variierungsinkrement nur dann rechnen dürfe, wenn er von ihm keine bestimmte Grösse voraussetzt, sondern ilmm gestattet, sich der Null beliebig zu nähern, und will ich dies durch ein mathentatisches Zeichen ausdrücken, so ist das einzig richtige $\mathrm{dx}$. Ob die wirklichen Variierungsinkremente messbar sind oder nicht, ist dạbei ganz gleichgiltig. Ubrigens ist Emery im Irrtum, wenn er meint, alle seien messbar. Die wenigsten sind es. Die Differenz in der Disposition zur Tuberkulose zwischen zwei völlig gesunden Individuen ist z. B. gewiss nicht messbar, und doch kann gerade hier eine, wenn auch noch so kleine Differenz, im Kampf ums Dasein den Ausschlag geben. 
Emery geforderte Intensitätsgrad! Nimmt man an, ein Tier habe 40,000 Millionen Kinder, von welchen nur 2 Individuen sich fortpflanzen, so wäre nach Emerys Rechnung dieser Selektionsprozess noch nicht einmal intensiv genug, um es wahrscheinlich werden zu lassen, dass diese $2 \mathrm{im}$ Durchschnitt sich irgendwie verbessert haben. ${ }^{1}$ Und dabei ist noch vorausgesetzt, dass die Selektion von den 40,000 Millionen wirklich ganz genau die 2 Besten herausgefunden hat. Dies wird natürlich nie der Fall sein. Denn je geringer die Prozentzahl der günstigen Variierungen ist, um so weniger wird das Resultat der Selektion von Variierungsvorteilen, um so mehr dagegen von Situationsvorteilen abhängen. Nehmen wir z. B. eine Tierklasse, bei welcher die Verhältniszahl der erzengten und der erhaltungsfähigen Individuen der von Emery geforderten Zahl vielleicht am nächsten kommt: die Bandwürmer. Nehmen wir also an, ein Bandwurm erzeuge während seines ganzen Lebens 40.000 Millionen Eier. Unter den abgehenden Eiern findet eine Selektion statt: nur die, welche vom $Z$ wischenwirt gefressen werden können sich zur Finne entwickeln. Es werden aber ungeheuer wenige gefressen, die meisten gehen ungefressen zu Grunde. Wir haben also eine intensive Selektion. Wovon hängt es aber $a b$, ob das Ei gefressen wird? Ganz ausschliesslich von äussern Umständen. Die individuellen Eigenschaften der Eier kommen nicht in Betracht. Wir haben also hier einen Selektionsprozess, bei welchem ein Einfluss der Variierungsvorteile absolut ausgeschaltet ist, bei welchem ausschliesslich Situationsvorteile in Betracht kommen. Nur in Bezug auf die Resistenzfähigkeit könnten Variierungsvorteile von Belang sein, die wir aber ausschalten können, indem wir uns auf ein bestimmtes Anpassungsgebilde beschränken (was überhaupt bei jeder Darwinistischen Betrachtung nötig ist), z. B. die Entstehung der Saugnäpfe, etc. Dass unter den relativ wenigen gefressenen Eiern sich eines von den 2 mit einer in Bezug auf die Saugnäpfe vorteilhaften Keimesanlage befinde, ist äusserst unwahrscheinlich. Die gefressenen Embryonen kommen nun 'zur engeren Wahl.' Nicht alle werden in fremden Organismus bleiben. Viele werden einfach abgehen. Bei diesem Selektionsprozess, der lange nicht so intensiv ist, als der erste,

${ }^{1}$ Wobei noch zu beachten ist, dass die Zahl roo der Elemente, in welche Emery ein Organ sich aufgelöst denkt, selbstverständlich eine willkürliche ist, und dass diese Zahl der Wirklichkeit natürlich um so näher kommen wird, je grösser sie angenommen wird. Wie enorm würde sich dann erst die Zahl der Kombinationen vermehren! Ubrigens kommt es auf die Zahlen gar nicht an: das Wichtige ist, dass mit der Emeryschen Annahme der Hypothesenkomplex, welchen die Selektionstheorie darstellt, um eine neue und zwar das Fundament betreffende Hypothese vermehrt würde. 
können auch (aber keineswegs ausschliesslich) Variierungsvorteile mitwirken. Die soweit gelangten Finnen kommen nun zu einer noch engern Wahl. Nur diejenigen entwickeln sich weiter, deren Zwischenwirte gefressen oder gegessen werden. Diesen Selektionsprozess können wieder eine Unzahl der verschiedensten Faktoren beeinflussen. Mehr oder weniger grosser Geschmack an rohem Fleisch, mehr oder weniger grosse Achtsamkeit der Sanitätsbehorden, diplomatischer Notenwechsel über Grenzverkehr: das sind alles Faktoren. die in Betracht kommen können. Eine schneidige Reichstagsrede kann unter Umständen über Tod und Leben von Tausenden von Bandwürmern entscheiden. Eine Klasse von Faktoren kommt aber ganz gewiss nicht in Betracht. das sind individuelle Vorteile der Finnen. Auch hier ist also die Wirkung der Variierungsvorteile ausgeschaltet. Unter den gefressenen oder gegessenen Finnen findet wahrscheinlich wiederum ein Selektionsprozess statt, bei welchem Variierungsvorteile (aber keineswegs ausschliesslich) mitwirken können. Von den 2 Individuen mit vorteilhaft variierten Saugnäpfen wird aber aller Wahrscheinlichkeit nach kein einziges zur letzten Wahl gekommen sein. Also selbst bei denjenigen Tieren, bei welchen die Überproduktion die grösste ist, könnte nach der Emeryschen Rechnung die Selektionstheorie zur Erklärung der Anpassungserscheinungen nicht mehr verwendet werden."

${ }^{16}$ See Piepers, M. C., "Mimikry, Selektion, Darwinismus," I903, pp. $376 \mathrm{ff}$. Author shows how an enormous mortality among oysters can occur withont any reference to their fitness for lite, and also gives other interesting cases of indiscriminate nonselective mortality.

${ }^{17}$ Kellogg and Bell, "Studies of Variation in Insects," Proc. Wash Acad. Sci., Vol. VI, pp. 203-332, I904. I quote the following :

"There are certainly few selectionists left who honestly believe that the minute fluctuating variations in pattern, in size, in curve

Example of non- of a vein, in length of a hair, etc., have that lifeselection of trivial and-death value which is the sole sort of value that differences.

an 'advantageous variation' must have to be a serviceable handle for the action of natural selection. As a matter of fact, no systematist will have escaped having had it distinctly impressed on him that he recognises differences in the pattern of lady-bird beetles, in the number of fin rays in fishes, in the branching of a vein in flies' wings, that no enemy, no agent of natural selection, can recognise, at least to the extent of pronouncing sentence of death (or not pronouncing it) on its basis. And further, no biologist really satisfies himself with the worn statement, "We must not presume to judge the value of these trivial, 
these microscopic differences, for we do not know all the complex interrelation and interaction of the organism and its environment.' We do not, but we do know for many cases that such differences are actually not of life-and-death selective value, and reason compels us to believe to a moral certainty that in other cases these fortuitous trivialities have similar lack of life-and-death importance. The case of the variation of the convergent lady-bird beetle, Hippodamia convergens (p. 275 et scq.), is distinctly in point. In our account of this variation we have called attention to the suggestiveness, in its light on the rigour of the 'struggle for existence' among individuals, of the fact that among several thousand individuals, gathered together to hibernate after an active life, having been exposed to the attacks of bird and insect enemies, to the rigours of climatic conditions and to the necessities of obtaining food (other smaller insects, as aphids, etc., caught alive), such a range of variation in pattern is found as enables us to describe (so that they may be actually readily distinguished by verbal description), eighty-four 'aberrations' or pattern-variates; lady-birds with no spots, with one, with two, with three, with each of all the numbers up to and including eighteen distinct small black spots, the different numbers usually being represented by several different combinations of spots. Systematic entomologists describe Hippodamia convergens as a brown-red beetle with six black spots on each elytron, and this description is true for most beetles of this species. But not at all for all; nor even approximately for many. After a season of exposure to the struggle for existence, to the rigours of selection, - individuals with one spot, with six spots, with twelve spots, with eighteen, find themselves alive and healthy; they come together to pass a quiet winter under the fallen oak leaves on a mountain side, ready to mate miscellaneously in the spring, and produce young of all manner of pattern (as far as number and arrangement of spots go); which young, whether twelve-spotted as they ought to be, or no-spotted, or eighteen-spotted as they may be, will apparently go safely through life despite the malevolent search of the all-powerful Inquisitor, Rigour of Selection!

"Directly touching this point, too, are our data of the variation of series of honey-bees collected from free-flying individuals after exposure as adults to the rigours of outdoor life, as compared with the variation in the series of bees, adult, but collected just as issuing from the cells before being exposed as adults in any way to the external dangers of living. Series of both drones and workers representing both exposed and unexposed individuals were studied. The results of this examination are, put in one statement, that the variation among the exposed individuals is no less than that among. 
the unexposed individuals. This means that these various, mostly slight, blastogenic variations (although in such important organs as the wings) which occur among bees at the time of their issuance as active, winged creatures, are not of sufficient advantage or disadvantage to the individuals to lead to a weeding out (by death) or saving of such varying individuals by immediate selective action. Whatever the rigour and danger of the outdoor bee life, these variations seem to be insufficient to cut any figure in the persistence or non-persistence of any individual in the face of this rigour."

${ }^{18}$ Conn, H. W., "The Method of Evolution," pp. 72 ff., I 900.

${ }^{10}$ Wolff, G., "Beiträge zur Kritik der Darwin'schen Lehre," pp. 24 et seq., I 898 .

${ }^{20}$ Plate, L., "Über die Bedeutung des Darwin'schen Selectionsprinzip," pp. I7-I8, I903.

${ }^{21}$ Morgan, T. H., "Evolution and Adaptation," Igo3.

${ }^{22}$ De Vries, in a recent paper ("Ältere und Neuere Selektionsmethode," Biol. Centralbl., Vol. XXVI, pp. 385-395. I906), describes the new methods of plant amelioration adopted by the Svalfor Versuchsstation (Sweden). These methods have been determined largely by the acceptance of De Vries's mutations theory as a working hypothesis.

${ }^{23}$ For account of the breeding and amelioration (artificial selection) of plants see Darwin, "Variation of Animals and Plants

References to under Domestication," many editions; Bailey, L. books and papers H., "Plant-breeding," 4th ed., I906; Hays, W. M., on plant-breed- "Plant-breeding," Bull. 29, Div. Veg. Phys. and ing. Path., U. S. Dept. Agric., Igor; Webber, H. J., and Bessey, E. A., "Progress of Plant-breeding in the United States," Yearbook of U. S. Dept. Agric., for I889, pp. 465-490; Kellogg, V. L., "The Scientific Aspects of Luther Burbank's Work," Pop. Sci. Mo., pp. 363-374. Oct., Igo6 (reprinted in Appendix to chapter ix of this book).

${ }^{2}$ Pfeffer, Georg, "Die Umwandlung der Arten," pp. I9-20, I894.

${ }^{25}$ De Vries, H., "Species and Varieties, their Origin by Mutation," pp. 798-826, I905.

${ }^{26}$ Korschinsky, S., "Heterogenesis und Evolution," Naturwiss. Wochenschrift, Vol. XIV, p. 276, I899.

${ }^{27}$ Coe, C. G., "Nature versus Natural Selection," IS94. A book devoted wholly to denying any validity at all to natural selection.

${ }^{28}$ Delage, Yves. "L'Hérédité," 2d ed., p. 419. p. 843, I903.

${ }^{29}$ Morgan, T. H., "The Origin of Species through Selection Contrasted with their Origin through the Appearance of Definite Variations," Pop. Sci. Mo., pp. 54-65, May, I905. 
DARWINISM ATTACKED (CONTINUED): THE THEORY OF SEXUAL SELECTION.

THE differences between male and female individuals of a single species are often striking; recall the gorgeous

\section{Secondary} sexual differences.

colouring, the plumes and tufts and tail-feathers of many male birds compared with the sober and quiet plumage of their mates; the antlers of the stag, the mane of the lion and bison, the beard of the goat, many monkeys, and of man. Recall the mammæ of the female quadrupeds, the brood pouches of the female kangaroos and opossums, the small size, compared with their mates, of many female birds, the winglessness of many female insects. Other less familiar kinds of animals show sexual dimorphism or dichromatism in even more striking degree, while in many others the differences are less conspicuous but nevertheless perfectly obvious if some attention is given to looking for them. These differences in size, colour, general appearances, and various specific structural details in head, trunk, wings, feet, plumage, etc., are over and beyond those primary radical differences existing in all species in which the two sexes are differentiated. Some of these differences may, however, have obvious relation to the primary differences, in that they may be connected immediately with the act of pairing or with the work of rearing the young. The presence in male insects of complexly developed holding organs, and in female mammals of milk glands exemplifies differences of this category. A great many sexulal differences, however, have no such obvious direct relation to the function of producing and rearing the young. 
Such are the metallic purple and bronze colours of the male grackles compared with the dull brown of the females; the long tails and brilliant coloration of the male pheasants, the great, spreading, patterned tail of the peacock, the larger size or the winglessness of many female insects, etc. All these differences between male and female of the same species of animal, beyond or in addition to the differences between the actual primary reproductive organs, are known as secondary serual differences, or the characters themselves, which may be characteristics of physiology and habit as well as the more familiar ones of structure, are called secondary serual characters. The layman may not readily appreciate the abundance and the great variety of these characters, but it is a fact that almost all species of animals, excepting those in the lower invertebrate branches, show them, and if one will try to recall the aspect of the two sexes in one after another of the species of animals with which one is familiar, mammals, birds, insects, etc., one will begin to realise how widespread and significant are these secondary sexual characters.

Various biologists have made up classifications, from various points of view, of the different kinds of these char-

Classifications of secondary sezual characters. acters; one classification, like that of Kramer ${ }^{1}$ for the secondary sexulal characters of insects, may be based on the different parts of the body showing the differences between male and female individuals, as head, antennæ, thorax, wings, legs, abdomen, etc., and on the character of the differences themselves, as whether differences in structure or in colour and pattern. Another type of classification, and one more useful for our present discussion, is that based on the apparent significance or actual use of the differing characters. An excellent classification of this type is that of Plate. ${ }^{2}$ The following are the principal subdivisions of this classification with a few examples illustrating each: 
CLASSIFICATION OF THE EXTERNAL SECONDARY SEXUAL CHARACTERS.

Group A. Characters which are useful to the possessor, or to its young, or have an indirect relation to reproduction.

Sub-group I. Specialisations in organs which aid in the finding of individuals of the other sex. Examples, the extra-development of the antennæ in many male moths and beetles, the enlarged and divided eyes of certain flies and May-flies, the enlarged tactile feelers of male Daphnias, the larger or better wings of many male insects, the swimming membrane, in the breeding season, on the hind-legs of Molge paradoxa.

Sub-group 2. Specialisations that aid in mating. Examples, the clasping organs of many male crabs, the hectocotylus of octopuses, the expanded tarsi of many male insects, and in general, the accessory copulatory organs of innumerable various animal species.

Sub-group 3. Special size and form of the female due to the extradevelopment of the ovaries. Examples, in Psychid moths and parasitic Crustaceans.

Sub-group 4. Differences connected with care of the young. Examples, mammæ of female mammals, brood-pouch of marsupials, brood-sacs of male sea-horses, and brood-cavities in the back of male Pipa (a frog).

Sub-group 5. Specialisations for defence or offence. Examples, protective coloration of female birds and insects, mimicry by female butterflies, antlers of the stag, strong canines of many male mammals (wild boars, etc.), sting of the female honey-bee, spurs of the cock, greater size and strength of many male mammals and birds.

Sub-group 6. Differences in coloration which aid in the recognition of the sexes ("recognition marks" of Wallace).

Sub-group 7. Differences connected with various special habits of life. Examples, the pollen-baskets of the worker honey-bees, the winglessness of male fig-caprifying insects (Blastophaga), the large differences between males and females of certain insects where one sex lives parasitically, the other independently, as the scale insects, the Strepsiptera, etc., the beak differences in the New Zealand bird, Heteralocha acutirostris, whose male chisels out the hard wood with a short, broad beak, while the female extracts insect larvæ from decaying wood by means of a long, curved beak.

Group B. Exciting organs. These are found almost exclusively in the males only, and serve to indicate the sexual excitement of their possessors, and at the same time to stimulate or excite 
the females. The excitation of the male is manifest to the female through her senses of sight, hearing, and smell (in each case through one or more of these), and this perception gives rise reflexively to an excitation on the part of the female.

Sub-group I. The male characters may appeal to the sense of sight of the female: (a) by colours, as in the breeding plumage, or coloration, of many birds, fishes, amphibians, and reptiles, or, as in the constant brilliancy of colour and pattern in many butterflies, other insects, and spiders; or (b) by striking form. as the beard and hairy tufts of many monkeys and the extraordinary "horns" and processes of certain lamellicorn beetles; or (c) by movable processes (often strongly coloured), as the wattles and movable feathers (tail, etc.) of certain birds, swelling cheek or neck sacs of turkeys, etc.; or (d) by striking movements, as the dancing on the ground or tumbling and whirling in flight of certain birds, the mating-time battles of mammals, birds, and fishes, and the "love-dances" of spiders.

Sub-group 2. The male characters appeal to the sense of hearing of the females, as the song of birds, the cries and calls of many mammals, frogs, and insects.

Sub-group 3. The male characters appeal to the sense of smell of the females, as the odours given off by goats, chamois, muskdeer, beaver, etc., and from the scent-scales (androconia) of many male butterflies.

Group C. Reciprocal organs; that is. organs which exist in functional condition in one sex but are inherited by the other only in rudimentary and often non-functional form.

Examples; the reduced mammæ of male mammals, the brood pouch of the male Thylacinus; wingless female butterflies often have a rudimentary sucking proboscis, which in some cases is inherited by the males without any reduction of the wings; in cases of mimicry by female butterflies, the males often show some traces of the changed colour-pattern; traces of spurs in female pheasants, reduced horns of female antelopes and goats, small "horns" on female lamellicorn beetles, undeveloped stridulating apparatus in female crickets. katydids, etc.

Group D. Indifferent characters, without any apparent utility.

Sub-group I. Rudimentary organs, which are wholly non-functional in one sex, although still functional in the other. Examples, the reduced wings of many female insects, the rudimentary alimentary canal of male Rotatoria.

Sub-group 2. Negative characters, that is, those wholly failing in one sex, although present in the other. This lack can be a 
primary one, that is, indicate an older phyletic condition, as the absence of antlers in the female deer; or be a secondary one, that is, gradually acquired by progressive reduction, as the loss of wings by many female insects.

Sub-group 3. Atavistic characters, as the more marked hairiness on the breast of men as compared with women.

Sub-group 4. Correlated characters, which may be called into existence by other organs present; with the female mollusc Anodonta, the shell is more strongly bowed in adaptive correlation with the expanded brood chamber between the gills.

Sub-group 5. A large number of secondary sexual characters which are incapable of specific classification, as the minute differences between the sexes in size and habitus; slight differences in wing form in humming-birds, dragon-flies, and butterflies; small differences in character and number of tarsal and antennal segments of many insects.

As Plate justly remarks the foregoing classification can, of course, make no pretension to completeness. But it

Apparent significance of the characters. indicates sufficiently clearly certain important differences among the secondary sexual characters; differences especially important in connection with any attempt to get at an explanation of the why and how of these characters. Such a classification shows that many of these characters have uses which are of a kind directly helpful in the struggle for existence, as the strong antlers of the stags, useful in defence against attacking enemies; the brood sacs of the kangaroos and opossum, useful in caring for their helpless young; the milk-glands and teats of all female mammals, the pollen-baskets and waxglands of the honey-bee which make the workers more effective food-gatherers and food-storers, and the protective colours and patterns of many insects and birds. But others, many others, indeed, of these secondary sexual characters, are either of a kind apparently useless in the struggle for life, or even of a kind actually harmful. Of apparent uselessness are the reduced wings of some male insects, and the host of slight differences in coloration, pattern, size, or 
shape, of different body-parts or of the whole body, the beards and hair-tufts of many'male mammals and the combs and wattles of male gallinaceous birds. Of apparent harmfulness are those ultra-developed pro-thoracic and head processes, "horns," of stag and other lamellicorn beetles, the conspicuous staring colours of many male birds, the long dangling plumes, the weighty crests, and heavy dragging tails of others, all these parts also usually being dangerously conspicuously coloured. The lively loud song of many male birds, and the dancing and leaping of numerous male spiders and some male birds must also involve some danger to the performers by attracting the attention of their enemies. In fact most of those secondary sexual characters that are classified under the general head of "exciting organs" are apparently of a sort that should be actually disadvantageous in the struggle for existence. They are of a character tending to make their possessors conspicuous and thus readily perceived by their carnivorous enemies. How is to be explained the existence of so many and such highly cleveloped structural and physiological characters of this kind, a condition that seems to stand in direct opposition to the theory of natural selection? Darwin's answer to this question is contained in his theory of sexual selection.

This theory, in few words, is that there is practically a competition or struggle for mating, and that those males are

Darwin's theory of sexual selection. successful in this struggle which are the strongest and best equipped for battle among themselves, or which are most acceptable, by reason of ornament or other attractiveness, to the females. In the former case mating with a certain female depends upon overcoming in fight the other suitors, the female being the passive reward of the victor; in the second case the female is presumed to exercise a choice, this choice depending upon the attractiveness of the male (due to colour, pattern, plumes, processes, odour, song, etc.). The actual fighting among 
males and the winning of the females by the victor, are observed facts in the life of numerous animal species. But a special sexual selection theory is hardly necessary to explain the development of the fighting equipment, antlers, spurs, claws, etc. This fighting array of the male is simply a special phase of the already recognised intra-specific struggle; it is not a fight for room or food, but for the chance to mate. But this chance often depends on the issue of a life-anddeath struggle. Natural selection would thus account for the development of the weapons for this struggle.

For the development, however, of such secondary sexual characters as ornament, whether of special plumage, colour, pattern, or processes, and song, and special odours, and "love-dancing," the natural selection theory can in no way account; the theory of sexual selection was the logical and necessary auxiliary theory, and when first proposed by Darwin ${ }^{3}$ met with quick and wide acceptance. Wallace in particular took up the theory and applied it to explain many cases of remarkable plumage and pattern development among birds. Later as he analysed more carefully his cases, and those proposed by others, he became doubtful, and finally wholly sceptical ${ }^{*}$ of the theory.

The theory as proposed by Darwin was based on the following general assumptions, for the proof of each of which a

\section{Postulated} bases of the theory. few to many facts were adduced. First, many secondary sexual characters are not explicable by natural selection; they are not useful in the struggle for life. Second, the males seek the females for the sake of pairing. Third, the males are more abundant than the females. Fourth, in many cases there is a struggle among the males for the possession of the females. Fifth, in many other cases the females choose, in general, those males specially distinguished by more brilliant colours, more conspicuous ornaments, or other attractive characters. Sixth, many males sing, or dance, or otherwise draw to 
themselves the attention of the females, Seventh, the secondary sexual characters are especially variable. Darwin believed that he had observed certain other conditions to exist which helped make the sexual selection theory probable, but the conditions noted are sufficient if they truly exist.

Exposed to careful scrutiny and criticism-an admirable and convincing example of such scientific and impar-

Scratiny and criticism of the theory, tial criticism is Kramer's analysis of the secondary sexual characters of European insects-the theory of sexual selection has been relieved of all necessity of explaining any but two categories of secondary sexual characters, namely the special weapons borne by males, and the special ornaments and excitatory organs of the males and females. For examination has disclosed the fact that males are not alone ${ }^{5}$ in the possession of special characters of attraction or excitation. Regarding these two categories Plate, ${ }^{6}$ in his able recent defence of Darwinism, says, "the first part of this theory, the origin of the special defensive and offensive weapons of males through sexual selection is nearly universally accepted. The second part of the theory, the origin of exciting organs has given rise to much controversy. Undoubtedly the presumption that the females compare the males and then choose only those which have the most attractive colours, the finest song, or the most agreeable odour, presents great difficulties, but it is doubtful if it is possible to replace this explanation by a better." Some of these difficulties may be briefly enumerated.

The theory can be applied only to species in which the males are markedly more numerous than the femaies, or in

Males must be more numerous than females, or be polygamous, which the males are polygamous. In other cases there will be a female for each male whether he be ornamented or not; and the unornamented males can leave as many progeny as the ornamented ones, which would prevent any cumula- 
tion of ornamental variations by selection. As a matter of fact in a majority of animal species, at least among the vertebrates, males and females exist in approximately equal numbers.

Observation shows that in most species the female is wholly passive in the matter of pairing, accepting the first Female is usn- male that offers. Note the cock and hens in ally passive. the barnyard.

Ornamental colours are as often a characteristic of males of kinds of animals in which there is no real pairing, as

Ornaments ocamong those which pair. How explain by cur on males that sexual selection the remarkable colours in the do not pair.

breeding season of many fishes, in which the female never, perhaps, even sees the male which fertilises her dropped eggs?

Choice on a basis of ornament and attractiveness implies a high degree of æsthetic development on the part of the females of animals for whose development in

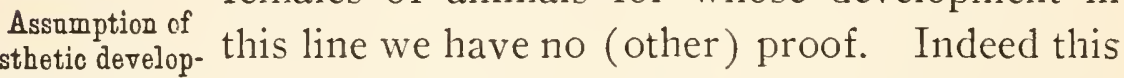
ment in lower choice demands rsthetic recognition among animals.

animals to which we distinctly deny such a development, as the butterflies and other insects in which secondary sexual characters of colour, etc., are abundant and conspicuous. Similarly with practically all invertebrate animals. Further, in those groups of higher animals where æsthetic choice may be presumed possible we have repeated evidence that preferences vary with individuals. Certainly they do with man, the animal species in which such preferences certainly and most conspicuously exist. In some human races hair on the face is thought beautiful; in others, ugly. Besides even if we may attribute fairly a certain amount of æsthetic feeling to such animals as mammals and birds, is this feeling to be so keen as to lead the female to make choice among only slightly differing patterns of songs? Yet this assumption is necessary if the development 
of ornament and other attracting and exciting organs is to be explained by the selection and gradual cumulation through generations of slight fortuitously appearing fluctuating variations in the males.

There are actually very few recorded cases where the observer believes that he has noted an actual choice by a Few observed female. Darwin records eight cases among cases of choice birds. Since Darwin not more than half a by female.

dozen other cases, all doubtful, have been recorded. Also a few instances, all more illustrative of sexual excitation of females resulting from the perception of odour or actions, than any degree of choice by females, have been listed.

In numerous cases the so-called attractive characters of the males, described usually from preserved (museum)

Somoso-called specimens, have been found, in actual life, to Someso-called
attractive char- be of such a character that they cannot be noted acters not visible by the female. For example, the brilliant in nature.

colours and the curious horns of the males of the dung beetles are, in life, always so obscured by dirt and filth that there can be no question of display to the female eyes about them. The dancing swarms of many kinds of insects are found to be composed of males alone. with no females near enough to see; it is no case of an: excitatory flitting and whirling of many males before the eyes of the impressionable females. Of many male katydids singing in the shrubbery will not for any female that particular song be the loudest and the most convincing that proceeds from the nearest male, not the most expert or the strongest stridulator? Similarly with the flitting male fireflies; will not the strongest gleam be, for any female, that from the male which happens to fly nearest her, and not from the distant male with ever so much better, stronger light?

Stolzmann finds it difficult to understand, when nearly 
related species differ widely in their ornamental plumage, that this should be attributed to a difference in Problem of preference among the females of the related the Andean humming-birds. species. The humming-bird, Schistes personatus, lives in Ecuador on the west side of the Andes, in a restricted range of four degrees of latitude. It is distinguished from the nearly related Schistes geoffroyi especially in the possession by its male of a brilliant spot over each eye. Schistes geoffroyi lives on the east side of the Andes from Colombia to Central Peru, with a range covering over twenty degrees of latitude, which range is divided into two completely separated regions by the Marañon valley. Now if isolation alone is sufficient to produce a change in the taste of the females, one would expect to find two sorts of males (as far as ornamental pattern goes) inside this one species. But there is but one kind of male tinrough the whole range. Why is the taste of the female constant through twenty degrees of latitude, while it is changed on the other side of the Andes in a limited range of four degrees of latitude? Another case presented by Stolzmann is even more striking. The Chilian hummer, Eustephanus galeritus, which is green in both sexes, has migrated from the continent to the Juan Fernandez Islands. On Masatierra Island it has changed to Eust. fernandensis, in Masafuera Island to Eust. leyboldi. These two species agree in the females with the original continental form (that is, are green) while the males have become red, but in different pattern in the two species. Eust. galeritus (the Continental form) also occurs on Masatierra Island, in the same form as on the continent, that is, with green male. Now one must presume from this state of affairs that this species (galeritus) has been able to reach Masatierra twice, once long ago-the descendants of the invasion having changed to Eust. fernandensis-and once more recentlythe descendants of these later migrants showing as yet no 
sign of a transformation of the male colour. Shall one in this case and others like it, asks Stolzmann, assume a change of beauty-ideal on the part of the females? Much simpler and much more reasonable, according to Stolzmann, is it to see in the change of colour of the males of the earlier migrants the results of the direct influence of the new environment; the islands are distinctly milder and warmer than the continent.

Even if the females do choose among the males on a basis of attractiveness, how are the characters of the more at-

How are more attractive characters to be fostered? tractive males to become especially fostered and accumulated by selection? Do such males produce more offspring or more vigorous ones than the other males, which, though rejected by the first females, find their mates among the females not already mated? Are we to attribute to the more ornamental males a particular vigour? If so, may not that very vigour be the cause of the extra-production of colour or plumage or wattles, etc.?

Darwin admits, in order to explain the beginnings of colour and ornament development, a certain degree of differ-

Darwin's signifcant admission.

ence between the male and female in regard to their reaction to environmental infuences. If so, may not these admitted differences be really sufficient to account for even a pretty high degree of difference in development of secondary sexual characters?

The special display of colours, tufts, plumes, spreading tails, and other secondary sexual characters by the males at mating time is an observed fact; the "dances"

Does display
prove choice? birds, the evolutions of the male spiders are all familiar phenomena in the mating season of these animals. And they probably do exercise an exciting effect on the females, and are probably actually displayed for this purpose. But does this in any way prove, or even give basis for a reasonable presumption for belief in a discriminating 
and definitive choice among the males on the part of the female? And it is this actual choosing which is the necessary basis for the theory of sexual selection.

How explain the well-known cases of a similar extradevelopment of plumage in the nuptial season by both

How explain ornaments in females or common to both sezes? males and females, as in certain herons and other birds? And what of those other cases in which it is the female that is the brighter-coloured individual of the pair? To explain the latter case Darwin assumes that in these cases the males have done the selecting, but even this rather too easy reversal of the situation postulated as a fundamental generalisation of the theory does not explain the first of the questions in this paragraph. Do both sexes among the herons do selecting?

Morgan " lists twenty objections to the sexual selection theory, several of which are identical with those already mentioned in the foregoing paragraphs, but of objections.

referred. One of these is that "some of the objections that apply to the theory of natural selection apply also with equal force to the theory of sexual selection in so far as the results in both cases are supposed to be the outcome of the selection of individual, or fuctuating, variations. If these variations appear in only a few individuals, their perpetuation is not possible, since they will soon disappear through crossing. It would be, of course, preposterous to suppose that at any one time only those few individuals pair and leave descendants that have secondary sexual characters developed to the highest point, but if something of this sort does not occur, the extreme of fluctuating variations cannot be maintained. Even if half of the individuals are selected in each generation, the accumulation of a variation in a given direction could not go very far. The assumption, however, that only half of all 
the individuals that reach maturity breed, and that all of these are chosen on account of the special development of their secondary sexual characters, seems preposterous. Furthermore, if it is assumed that the high development of the new character appears in a large number of individuals, then it is not improbable that its continued appearance might be accounted for without bringing in, at all, the hypothesis of sexual selection."

Again, Morgan well points out that "the development, or the presence, of the rsthetic feeling in the selecting sex is not accounted for on the theory. There is just as much need to explain why the females are gifted with an appreciation of the beautiful as why the beautiful colours develop in the males. Shall we assume that still another process of selection is going on, as a result of which those females are selected by the males that appreciate their unusual beauty, or that those females whose taste has soared a little higher than that of the average (a variation of this sort having appeared) select males to correspond, and thus the two continue heaping up the ornaments on one side and the appreciation of these ornaments on the other? No doubt an interesting fiction could be built up along these lines, but would any one believe it, and if he did, could he prove it?

"Darwin assumes that the appreciation on the part of the female is always present, and he thus simplifies, in appearance, the problem, but he leaves half of it unexplained.

"There is another side to the question," also says Morgan, "the importance of which is so great, that it is surprising that Darwin has not taken any notice of it. If, in order to bring about, or even maintain, the results of sexual selection, such a tremendous elimination of individuals must take place, it is surprising that natural selection would not counteract this by destroying those species in which a process, so useless for the welfare of the species, is going 
on. It is curious that this has not been realised by those who believe in both of these two hypotheses.

"What has just been said applies also with almost equal force to the development of such structures as the horns of the deer, bison, antelopes, and the brilliant colours of many insects and birds. If in nature, competition between species takes place on the scale that the Darwinian theory of natural selection postulates, such forms, if they are much exposed, would be needlessly reduced in numbers in the process of acquiring these structures. So many individuals would have been at such a disadvantage in breeding, that if competition is as severe as the theory of natural selection postulates, these species could hardly be expected to compete successfully with other species in which sexual selection was not taking place."

Finally to make an end of miscellaneous objections and come to that one which promises to be, if it is not already,

Experimental evidenco is opposed to sexual selection theory. the most serious obstacle in the way of the sexual selection theory, it is a fact that all the evidence (though it be little as yet) based on actual experiment is strongly opposed to the validity of the assumption that the females make a choice among males based on the presence in the males of ornament or attractive colours, pattern, or special structures. I may mention especially the striking experiments of Mayer ${ }^{8}$ (which, published in a small entomological journal of limited circulation, have not received the attention that they deserve) on the large Bombycine moth, Callosamia promethea. This well-known American moth expands about three and one-half inches and shows unusually pronounced secondary sexual differences as to colour and pattern. The females are reddish-brown in ground colour, while the males are blackish and in the two sexes the pattern is distinctly different. If there is any moth species in which the colours and general pattern of the male ought to be readily obvious 
to the female, and in which sexual selection might be presumed to have been the influence in producing a pronounced

Mayer's experiments $\mathrm{Cn}$ Promethea, male type of preferred pattern, it is this. species. Mayer's simple and convincing experiments were as follows: Mayer took four hundred and forty-nine pupæ (in cocoons) of the moth Callosamia promethca, which had been collected in Massachusetts and New Jersey, south to Loggerhead Key in the Dry Tortugas Islands off Florida. This island is separated by many miles of ocean from other land, and is hundreds of miles south of the range of the species. Evidently no interference with Mayer's experiments could come from outside individuals of this species. The moths issued during May and June in the proportion of about two males for each female. The males of this species seek out the female for pairing and can do this for a considerable distance. As many as several dozen males will find a single female and hover, fluttering, about her. Mayer's first experiments were directed to the end of determining if the males found the females by sight or by smell. By enclosing females in numerous jars variously arranged and covered or uncovered, it was readily determinable that males never pay any attention to females enclosed in transparent jars so closed as to prevent the escape of any odours from the female, while to females enclosed in boxes or wrapped in cotton so as to be invisible but yet capable of giving odour off into the air males came promptly and hovered about. To locate the organs of scent in the female Mayer cut off abdomens from various females and then placed abdomens and abdomenless females at some little distance apart. Males came to the abdomens and not to the thorax plus wings, legs, and head parts. Females were proved to increase in attractive power with age, and virgins are a little, but only a little, more attractive than already fertilised females. It was readily proved, by experiments with males whose an- 
tennæ were covered with shellac, photographic paste, glue, paraffin, etc., that the sense of smell is seated in the antennx. Males with antennæ covered with photographic paste did not find females, while the same males with this paste dissolved off did.

Nayer now tried to test the selective action of the female. The male promethea has blackish wings while the females are reddish-brown. In accordance with the theory of sexual selection, the peculiar coloration of the male should be due to the selection of dark-coloured males, so that under this influence the males would become, in successive generations, darker and darker until the present coloration has been attained. Mayer's own account of his experiments and conclusions to test the preferences and selective action of the females is as follows:

"In order to test this hypothesis I cut off the wings of a number of females, leaving only short stumps, from which all the scales were carefully brushed. Male wings were then neatly glued to the stumps, and thus the female presented the appearance of a male. Under these circumstances the males mated with the female quite as readily as they would have done under normal conditions.

"I then tried the experiment of gluing female wings upon the male. Here again the mating seemed to occur with normal frequency, and I was unable to detect that the females displayed any unusual aversion toward their effeminate-looking consorts.

"It is also interesting to note that normal males pay no attention to males with female wings.

"In another series of experiments the wings were cut entirely off of males and females and the scales brushed off their bodies; and yet these shabby males were readily accepted by normal females, nor could I see that normal males displayed any aversion to mating with wingless females. 
"We are therefore forced to conclude that the melanic coloration of the male has not been brought about through the agency of sexual selection on the part of the female."

More recently Mayer (and Soule) ${ }^{9}$ repeated these experiments on a more extensive scale and with some variations

Mayer and in character. Fifteen hundred cocoons of Soule's experi- Promethea were collected in the winter of IgoIments.

$\mathrm{O} 2$ and hung in trees so that the issuing moths might fly about unconfined. "About six hundred males emerged from the cocoons and the wings of about one-half of them were painted with scarlet or green ink, while the others were allowed to remain normal in colour. It was evident that the males whose wings were scarlet and green succeeded fully as well in their attempts to mate as did the normal males."

Experiments were also tried with the moth Porthetria dispar, in which the male is brown and the female white. The experiments showed that males with wings painted scarlet or green were accepted as readily as normal males, but that males with the wings cut off were more apt to meet with resistance from the females than perfect males were. From these experiments Mayer and Soule conclude that the mating instinct in the males of $C$. promethea and $P$. dispar is a phenomenon of chemotaxis. Sexual selection on the ground of colour alone does not affect it, and there is no associative memory connected with it.

To these experiments may be added the observations of Douglass, ${ }^{10}$ who found that females of the wall-lizard, Lacerta muralis, showed no preference whatExperiments ever among the variable patterns exhibited by on lizards.

males in breeding-coat. Dürigen ${ }^{11}$ observed that male lizards without tails are accepted readily by females.

Finally, also, of the nature of objections to the sexual selection theory are the replacing or substutionary explana- 
tions of secondary sexual characters which various biologists have offered. These explanations will be presented Alternative ex-in some detail in chapter $x i$, which is devoted planations of sec-
ondary seznal cbaracters. theories proposed to replace or partially to replace the Darwinian theories. It must be sufficient to say here that the theories proposed to account for secondary sexual characters mostly rest on one or both of two principal basic assumptions; first, that the secondary sexual characters are produced as the result of the immediate stimulus (naturally different) of the sexually differing primary reproductive organs, this stimulus being usually considered to result from an internal secretion of the genital organs acting on certain tissues of the organism; and, second, that the males in most species possess an excess of energy which manifests. itself in extra-growths, extra-development of pigment, plumage, etc., and that displays by the males of special movements, sound-making, etc., are direct effects or manifestations of sexual excitation. To these explanations should be added the rather far-fetched one of Emery, who believes that many cases of secondary sexual differences are explained by the sudden appearance (mutation) of another form of male or female, the persistence for a while of the two forms side by side, as now exists in numerous dimorphic species (especially among insects), and then the gradual dying out (killing out by natural selection) of one of the two old original forms (the one like the other sex), thus leaving the other, or aberrant form. The ideas of Cunningham, ${ }^{12}$ who does not believe that any selection of fortuitous variation can account for secondary sexual characters, may also be referred to. In a book of over three hundred pages this author lists and describes-according to principal animal groups-a host of secondary sexual characters, and proposes a theory to account for them. "The direct effects," writes Cunningham, "of regularly recurrent stimulations are 
sooner or later developed by heredity, but only in association with the physiological conditions under which they were originally produced. This is the explanation of the limitations of particular modifications not merely to particular species or kinships, but to particular periods in the life of the individual, to a particular sex and even to a particular season of the year in that sex." The author believes that an examination of secondary sexual characters shows that they develop at places and in parts which are at the time of sexual excitement unusually directly stimulated by exertion or contact or use. These secondary sexual characters are "in many cases not merely limited to the period of mature life but actually to that part of the year in which the reproductive organs are active, that is to the breeding season."

In closing this chapter given up to objections to the Darwinian theories of natural and sexual selection, attention may be called to Wolff's ${ }^{13}$ objection to natural

Importance of selection based upon the dependence of the nathe sexual selection theory as a support of the natural selection theory.

tural selection theory on the sexual selection theory for explanation of the existence of ornamental characters, and of all these secondary sexual characters, which are useless or even apparently disadvantageous in the life-and-death interspecific struggle for space and food. As Wolff looks on the sexual selection theory as wholly discredited, he finds this necessary dependence on it by believers in natural selection for the explanation of those characters just mentioned strong evidence for the weakness of the natural selection theory.

\section{APPENDIX.}

${ }^{1}$ Kramer, Paul, "Theorie u. Erfahrung ; Beiträge zur Beurtheilung des Darwinismus," 1877, Halle. An interesting paper criticising the selection theories from two points of view; first, on the basis of a mathematical treatment of the Darwinian hypothesis (especially that of sexual selection), the author taking Darwin's premises and by a mathematical handling of them showing that they do not lead 
to the Darwinian conclusions; and, second, on a basis of the careful scrutiny of the facts of secondary sexual differences, the author finding sexual selection wholly unable to account for the great majority of secondary sexual characters among animals.

${ }^{2}$ Plate, L., "Über die Bedeutung des Darwin'schen Selectionsprinzips," pp. I07-III, 2d. ed., I903, Leipzig.

${ }^{3}$ Darwin outlined the theory of sexual selection in the "Origin of Species" (I859), but first treated it at length in the "Descent of Man" (Parts II and III), I87I.

"Wallace, A. R., "Tropical Nature," chap. v, I878; and "Darwinism," chap. x, I89I, London.

${ }^{5}$ Doane (Ent. Nezus, Vol. XVIII, pp. I36-I38, I907) has described the striking behaviour during mating of certain Dolichopodid flies (Scellus virago, n. sp.) observed by him on the salt marsh flats of San Francisco Bay, near Stanford University. In these matings it is the female which is the active sex in pursuing and exciting the other.

${ }^{6}$ See note 2.

"Morgan, T. H., "Evolution and Adaptation," chap. vi, I903, New York. This chapter is an exhaustive attack on the theory of sexual selection.

${ }^{8}$ Mayer, A. G., "On the Mating Instinct in Moths," Psyche, Vol. IX, pp. I5-20, I900.

'Mayer, A. G., and Soule, C. G., "Some Reactions of Caterpillars and Moths," Jour. Exper. Zool., Vol. III, pp. 427-431, 1906.

${ }^{10}$ Douglass, N. G., "On the Darwinian Hypothesis of Sexual Selection," Nat. Scicnce, Vol. VII, pp., 398-406, I895.

${ }^{11}$ Dürigen, "Deutschlands Amphibien u. Reptilien," p. 89, I897.

${ }^{12}$ Cunningham, J. T., "Sexual Dimorphism in the Animal Kingdom," I900.

${ }^{13}$ Wolff, Gustav, "Beiträge zur Kritik der Darwin'schen Lehre," p. 2 I ff., I898, Leipzig. A bitter but keen and trenchant critical exposition of certain weaknesses in the selection theories. He criticises the theory of sexual selection in the following words:

"An diese Fälle reiht sich vielleicht am besten die Betrachtung der Folgen, welche frühzeitige Sterilität auf die Ausbildung von Wolff's exposi- sekundären Geschlechtscharakteren ausübt. Wir köntion of weak- nen ja diese Erscheinungen auch in gewissem Sinne nesses in sexual zu den Rückbildungen rechnen; sie haben aber insbeselection. sondere auch das mit den vorigen Fällen gemeinsam, dass wir hier ebenfalls einen in individuellen Leben des Organismus sich abspielenden Vorgang beobachten können, der nach der Selektionstheorie nicht eintreten durfte.

"Nach der Selektionstheorie entstehen ja sekundäre Geschlechts- 
merkmale dadurch, dass eben Individuen des einen Geschlechts, bei welchen durch zufällige Variierung eine Andeutung solch eines Merkmals da war, mehr Chancen hatten, sich fortzupflanzen und diese Eigentümlichkeit auf die Nachkommen ihres Geschlechts zu vererben, von denen dann durch den gleichen Prozess immer diejenigen zur Fortpflanzung ausgewählt wurden, welche die betreffende Eigentümlichkeit am stärksten besassen. Es soll also zwischen jenen Gebilden und dem Geschäfte der Zeugung an und für sich nicht der geringste Zusammenhang existieren. Dann ist aber schwer erklärlich, warum jene sekundären Geschlechtsmerkmale sich häufig nur zur Zeit der Geschlechtsthätigkeit bilden und nachher wieder verschwinden, wie z. B. der Hochzeitskamm der Tritonen. Aber geben wir einmal zu, das sei bloss ein zufälliges Zusammentreffen, indem eben diejenigen zur Fortpflanzung gelangten. welche gerade zufällig um die Zeit der Brunst eine bald wieder zufällig verschwindende Verstärkung des Kammes besassen. Es ist zwar unmöglich, sich dies, insbesondere das Verschwinden des Kammes, vorzustellen, weil ja, wenn auch das spätere Verschwinden des Kammes dem Tiere irgend einen Vorteil gebracht haben sollte, dieser bei der Selektion in keiner Weise s:ch geltend machen konnte, oder doch nur in Bezug auf das Individuum aber nicht auf dessen Nachkommen, aber nehmen wir einmal an, das sei alles in Ordnung: wie erklärt sich dann, dass, z. B. beim kastrierten Hirsch kein Geweih sich entwickelt, dass der kastrierte Mensch hohe Stimme behält. keinen Bart bekommt u. s. w., u. s. w.?

"Auch andere Rückbildungen. welche nach Aufhören der Geschlechtsthätigkeit normal sich einstellen (z. B. Aufhören der Flimmerbewegung im Uterus des Weibes nach Aufhören der Menstruation, Verlust der Flügel nach der Begattung bei Insekten,* etc.), bieten der Selektion die grössten Schwierigkeiten, denn wenn hier die Rückbildung einen Vorteil böte. welcher die Auswahl der Individuen, bei welchen diese Rückbildung auftrat, herbeiführte, so könnte dieser Selektionsprozess doch erst nach der Fortpflanzungszeit eintreten, auf die nachfolgenden Geschlechter daher von keinem Einflusse melir sein.

"Der unbestreitbare Zusammenhang. welcher zwischen der Geschlechtsthätigkeit und den sekundären Geschlechtsmerkmalen besteht, ist nun aber nicht etwa durch das Wort 'Korrelatio:.' erklärt. Es ist natürlich richtig. dass eine Änderung irgend eine andere im Gefolge haben kann. dass es also korrelative Abänderungen giebt, aber ist denn damit vielleicht erklärt, dass eine bestimmte zweckmässige Abänderung nun auch eine andere für

* In diesem letzteren Fall ist vielleicht doch ein Vorteil für die Art durch Vermittlung der Brutpflege denkbar. 
den jeweilig vorliegenden ganz speziellen Fall nützliche Abänderung bedingt? Korrelative Abänderungen beziehen sich ja in den meisten Fällen, wo wir von solchen sprechen, auf ganz bestimmte Verhältnisse der Aussenwelt. Sich zur Erklärung solcher Erscheinungen mit der Konstatierung eines Gesetzes der Korrelation zufrieden geben, heisst einfach eine praestabilierte Harmonie zwischen der Entwicklung der Organismen und den Verhältnissen der Aussenwelt annelımen. Das Rätselhafte ist ja zunächst nicht der Umstand, dass es überhaupt Korrelationserscheinungen giebt (wenngleich wir natürlich auch hierfür ebensowenig, wie für irgend eine andere Lebenserscheinung eine Erklärung haben), sondern der Umstand, dass eine Eigentümlichkeit eine andere korrelativ im Gefolge hat, die eben gerade für besondere äussere Zwecke vorteilhaft ist. Hier kann die Selektionstheorie nichts ausrichten, denn der Selektionsprozess hat doch keinen Einfluss auf die Variierungsgesetze, zu welchen die Korrelationsgesetze gehören; diese müssen vielmehr vorausgesetzt werden.

"Es giebt übrigens Thatsachen, die mir darauf hinzudeuten scheinen, dass die korrelativen Beziehungen noch viel verwickelter sind, und dass korrelative Beziehungen gar nicht immer auf die Entstehung korrelativer Abänderungen zurückzuführen sind, sondern dass, was ja noch viel rätselhafter ist, eine Korrelation erst sekundär erworben werden kann, wie folgendes Beispiel zeigen dürfte.

"Von den drei verschiedenen Individuen des Bienenstaates hat nur die Arbeitsbiene an der Innenfläche des Tarsus regelmässige Borstenreihen, sogenannte Bürstchen. Da die Arbeitsteilung immer eine höhere Differenzierung ist, so kann es keinem Zweifel unterliegen, dass ursprünglich bei allen Formen die Beine gleich waren. Kaum zu entscheiden dürfte wohl die Frage sein. ob ursprünglich sich die Bürstchen sowohl bei männlichen als auch bei weiblichen Individuen differenzierten, sodass das Fehlen derselben bei den Drohnen als Rückbildung betrachtet werden müsste, oder ob die Bürstchen gleich von vornherein als sekundäres Geschlechtsmerkmal der Weibchen auftraten. Im erstern Fall wäre also die Bildung primär in keinerlei Korrelation zum Geschlechtsapparate gestanden, diese müsste vielmehr erst später erworben worden sein. Im zweiten Fall wären die Bürstchen als zum Geschlechtsapparate korrelative Bildungen entstanden, aber in beiden Fällen musste eine Änderung des Korrelationsverhältnisses eingetreten sein, die Korrelation musste nämlich eine reziproke werden: die Entstehung von Bürstchen ist zwar an das weibliche Geschlecht geknüpft. jedoch in der Weise, dass die Bürstchen nur auftreten, wenn die Geschlechtsorgane nicht zur Ausbildung kommen." 


\section{CHAPTER VI.}

\section{DARWINISM DEFENDED.}

Is taking up the defence of Darwinism it should be noted in the first place that the anti-Darwinians are without the

Advantageous position of the defenders of Darwinism, walls; that theirs is the burden of attack; that against them is the presumption of right. The Darwinians are in the castle, theirs simply the necessity of withstanding or repelling really significant and truly threatening attack; theirs the strength of possession and the presumption of truth. Much antiDarwinism is futile and easily answered; much was answered by Darwin * himself before ever the anti-Darwinians formulated it ; much other anti-Darwinism is directed against a position which Darwinism, true Darwinism, has long seen the inadvisability, indeer the impossibility, of holding. With certain concessions made, what use of further struggle over them? Thus by answering briefly the insignificant and undamaging part of anti-Darwinian attack, or by referring to Darwin's own answers of this, and by indicating clearly and definitely the concessions that Darwinism is ready to make, has made, indeed-these humiliating concessions, if humiliation is in them, only being made necessary because

*Darwin's anticipation of the criticisms of his theories, and his own open-minded and detailed answers to these criticisms, should, of course, be held clearly in mind by any student of für-undgegen Darwinismus, but many of these answers concern objections which present-day Darwinism has largely conceded as valid, and most of the others touch matters on which modern biological research has thrown much new light. So that it is perhaps fairer to the Darwinian theories to set out the attitude of present-day Darwinians. For a detailed critical consideration of Darwin's own answers, see Morgan, "Evolution and Adaptation" (1903). 
of the ill judgment and rash enthusiasm of certain too ardent and too conspicuous friends of Darwinism, the socalled neo-Darwinians-with this salutary restriction of diffuseness in account, "Darwinism Defended" may be confined to fewer pages than have been devoted to "Darwinism Attacked" without suggesting by this brevity any necessary weakness in the Darwinian position.

Let us give our first attention to the Darwinian concessions-those concessions which the biological world has

Reaction practically agreed have been made necessary by against ultra- the steady criticism of the exaggeration and Darwinism. magnification, almost wholly post-Darwinian in appearance, of the Darwinian factors in evolution. It is strange, but wholly true, that the modern reaction and revolt against Darwinism is chiefly due to the activity and attitude taken by certain of its over-ardent friends. Weismann, by denying validity to any other evolutionary factor than the natural selection of purely congenital variations, and by the development to an illogical and untenable extreme of his theory of the independence and continuity of the germplasm, precipitated the revolt and furnished the enemy with the very weapons needed to overcome neo-Darwinism. The evolution champion Haeckel, although not at all a Weismannian Darwinian, has also by his daring and reckless speculative development of certain phases of evolutionary thought, especially in its relation to sociology and religious philosophy, and by his obstinate adherence to, and reiteration of, certain long discredited more strictly biological

Haeckel. dogmas of evolutionary science, contributed to produce an irritation and antagonistic activity among biologists, especially in Germany, which has helped make many friends for the anti-Darwinian party. "Der Haeckelismus in der Zoologie," 1 as Semper originally phrased it, is the object of a curiously bitter and oftenexpressed contempt in German biological circles. I fancy 
that this feeling really depends not so much on Haeckel's attitude and speculative writing in zoology as in his unpardonable intrusion into politics and religion; the SocialDemocrats and the Free-Thinkers have found a helpful and willing scientific champion in Haeckel. And this is sin superlative in rigorous minds! As a matter of fact, however, biologists generally are agreed that Haeckel's daring speculations and reckless progress in advance of positions grounded on observed fact have been, in a way, always reprehensible and dangerous to the fair fame of biological science. But, to niy mind, biologists may also fairly agree that this very activity and speculative daring of Haeckel have inspired much genuine biological investigation (for the sake of denying or confirming his speculations) and have led to a salutary reactionary critical attitude toward other biological speculations and hypotheses. It is a rare ism in any science or philosoply that yields nothing good.

Weismannism is wholly different from Haeckelism. It has only in common with it that it is, in part, also daringly speculative. But the speculations primarily interest neither Free-Thinkers nor Social-Democrats. They have to do with the ultimate structure and behaviour of protoplasm, especially germinal protoplasm, and with the intimate processes of heredity and variation.

Weismann first attempted to free Darwin's general theory of modification and species-forming from all taint of Lamarckism; an attempt which resulted in his $\begin{aligned} & \text { Weismann's apparently successful overthrowal of the com- } \\ & \text { theories. } \\ & \text { monly accepted theory of the inheritance of }\end{aligned}$ acquired characters, a theory or assumption which is a fundamental and indispensable part of the general Lamarckian theory. (Lamarckism and the inheritance of acquired characters are explained and briefly discussed in chapter $\mathrm{x}$ of this book.) On the strength of this success Weismann proposed the doctrine of the Allmacht of natural selection; that 
is, that natural selection alone is capable of explaining all the phenomena and facts of species-forming and descent. At the same time he developed and announced the theory of the continuity of the germ-plasm, which, in a word, is the theory of an absolute separation of the germ-plasm from the soma-plasm and consequently the thorough independence of this germ-plasm from all influence and control of the soma-plasm, $i$. $e$., all that part of the body other than the germ cells. This carried with it the assumption that all the phenomena of heredity and variation depended solely on the germ-plasm and that the germ-plasm of any individual is derived, unmodified by any somatic influences, directly from the germ-plasm of its ancestors. This assumption in turn led to the logical but startling conclusion that all the capacity or possibility of variation for all time was present in that primitive ancestral germ-plasm from which the germplasm of all many-celled animals has been derived. But such a nearly infinite capacity for furnishing variations demanded the postulation of an equally nearly infinite capacity for actual physical or structural complexity on the part of the germplasm itself, for biologists insist on a physical mechanism for all the physiological phenomena they find in life. So Weismann assumed an interesting but invisible and apparently non-testable composition of germ-plasm out of life-units, called biophors, grouped into particles of a second order called determinants. The biophors are taken to be much larger and more complex units than chemical atoms, or even than molecules. They are groups of several to many molecules, each biophor, however, still ultra-microscopic, and representing a single characteristic of cell-life. Each biophor is assumed to possess the essential attributes of living substance, viz., the capacity to assimilate food, to grow, and to reproduce itself. The groups of biophors called determinants are larger, of course, but yet invisible to our best microscopes, and each represents all the characteristics which a 
cell of any particular single kind has. Thus one kind of determinant represents all the attributes of the red blood corpuscles, another of the nerve-ganglion cells, another of a certain type of epithelial cells, and so on. Each determinant has also the power of assimilating food, growing and reproducing itself by division. Now the possibility of representing in the germ-plasm the nearly infinite capacity to vary characteristic of this plasm has for its physical or mechanical basis the minute size of the biophors and determinants coupled with the inconceivably many combinations of different kinds of biophors possible in the make-up of the determinants which are, as already said, the actual structural representatives of, or better, controllers or producers of, the various kinds of body tissue and organs.

These three general assumptions of Weismann, ${ }^{3}$ namely, ( I) the composition of germ-plasm out of ultimate life-units called biophors (grouped into determinants) which determine all the physical characteristics of the individuals into which the germ-plasm develops; (2) the isolation (from the soma) and the continuity (from generation to generation, from beginning to end) of the germ-plasm; and (3) the Allmacht of natural selection. which involves the discarding of all other factors of modification and species-forming than the natural selection of the slight fluctuating congenital variations produced (in an unknown manner) by infinitesimal changes in the determinants of the germ-plasm-these three fundamental and important Weismannian assumptions, accepted more or less nearly completely by Wallace and a

Neo-Darwinism and NeoLamarckism. number of other English biologists, and by a few naturalists of Europe and America, constitute the essential position of what is called neo-Darwinism. This neo-Darwinism immediately found many capable antagonists, and as most of the antagonists were believers in some parts of the general theory of adaptation and species-forming first proposed by 
Lamarck, their position came to be known as neoLamarckism. Herbert Spencer in England, Packard, Osborn, and others in America, and Eimer in Germany were prominent exponents of the anti-Weismannian views. The debate was spirited, and engaged many biological writers, and interested the general reading public in the larger problems of biology more than it has been interested at any other time since the great struggle immediately following the publication of Darwin's "Origin of Species." The best known part of the general debate was that carried on directly by Weismann and Spencer in the Contemporary Reviere ( 1893 and 1894).

The general result of the struggle between neo-Darwinism and neo-Lamarckism can be fairly stated to be, that

Weismann's assault on the theory of the in-

Concessions of heritance of acquired characters was in general
Teo-Darwinians. Neo-Darwinians. successful; while, on the other hand, the assault of the anti-Weismannians on the assumptions of the isolation and continuity of the germ-plasm and of the Allmacht of natural selection forced from Weismann and his followers. one by one and slowly, such radical concessions as to make the latter doctrine utterly untenable, and to rob the other of most of its significance in the consideration of modification and species-forming. The assumption of the composition of germ-plasm out of biophors and determinants is of course merely an interesting speculation, or tentative hypothesis, which, because it is untestable by scientific observation or experiment, cannot be debated to any particular advantage. Weismann himself, in 1895 , definitely conceding that natural selection is radically weak at its base, being incapable of explaining the beginnings of useful variations and the development (which actually occurs) of indifferent ones, proposed a new and radically un-Darwinian theory under the name of Germinal Selection. This theory (explained in chapter viii of this book) although including the 
word selection in its name is fundamentally different from natural selection in the Darwinian sense, and is indeed an admission of the existence of variations maintained (not by means of natural selection) along definite lines, resulting in a real orthogenesis. It attempts to offer a causomechanical explanation of such un-Darwinian development. By the theory of germinal selection, which is based absolutely on the assumption that the plasm is composed of biophors and determinants or at least of physical life units of similar type and function, Weismann hopes to strengthen four weak places in the general position of neo-Darwinism. The theory explains (I) how in Panmixia (another Veismannian contribution to neo-Darwinism, for account of which see chapter viii) the degeneration of useless organs is brought about, (2) how it is that for the continued development of any certain complex adaptation exactly the right variations shall appear at the needed time, (3) how coadaptation comes to exist, and finally (4) how variations may come to be developed along fixed lines or in definite directions without the aid of personal selection. Whether the theory of germinal selection explains these four things or not, what is to us for the moment the chief interest of the theory is that it is put forward by Weismann, who is distinctly the foremost neo-Darwinian, to explain just these things. For that makes of these things concessions that the neo-Darwinians, the ultra-selectionists, feel forced to offer. It should be noted, however, that perhaps Weismann does not speak for all ultra-selectionists, for example, Lloyd Morgan, Ray Lankester, and other English "Darwinians. Certainly his theory of germinal selection is accepted by few of them.

On the whole, however, I think I speak perfectly fairly in saying that the believers and defenders of the natural selection theory to-day admit in large measure the validity of those criticisms which are directed at the inca- 
pacity of Darwinism, in its long familiar form, to account for the development of variations and modifications up to the advantageous or disadvantageous stage. They admit also the actual existence, and in abundant measure, of species differences which are of indifferent character, that is, of no especial utility, and make the consequent admission that such species differences cannot for the most part be explained by natural selection. And they also concede, or at least most of them, including Weismann, do, the force of the criticism that the assumption of the occurrence of the right variations at the right time is a necessity for the development by selection of many if not most specialisations of qualitative and of coadaptive character, which assumption in turn demands an explanation of causes anterior to selection.

And finally most selectionists concede that selection cannot make new species by relying on the extremes of series of fluctuating or Darwinian variations because of the inevitable extinguishing or swamping of these extreme variations by inter-breeding with the far more abundant. average or modal individuals of the species. Hence all those objections recorded in the chapters on "Darwinism Attacked" which have to do solely with this incapacity of natural selection to make use of variations too. small or too few or purely fortuitous, or with the incapacity of selection to explain hosts of indifferent, non-adaptive species differences which actually exist, and hence with the certainty of its not being the only factor, if indeed a principal factor, in the formation of species, need not be rediscussed, at least to any length, in this chapter. We may also largely neglect those objections which are directed against the purely hypothetical assumptions and the extreme positions of the neo-Darwinians. Many of these assumptions, such as that of the absolute isolation and independence from the soma of the germ-plasm, are not a part of Dar- 
winism proper, and the extreme position of the believers in the Allmacht of selection was certainly never taken by Darwin himself. In fact, most of neo-Darwinism has been deserted by its one-time followers, and most conspicuously and perhaps most radically by Weismann himself.

Thus, with these two categories of objections listed in the "Darwinism Attacked" chapter put to one side, for the moment at least, by admitting the validity of one category and showing the inapplicability of the other as regards its relation to true Darwinism, we have left to us The objections to consider those remaining objections which needing answer.

are made (I) against the capability of selection's making any use at all of the familiar and always occurring fluctuating variations called Darwinian, against its capacity to explain coadaptive and highly complex adaptations, especially those which seem as if they could be of advantage to the organism only in fully developed or specialised state, (3) against its inability to account for overdeveloped specialisations, (4) against the possibility of selection's explaining qualitative differences in species, and many-branched descent (quantitative differences and linear descent seeming to be the only kinds possible to it), (5) against its capacity to explain complete or extreme structural degeneration of useless organs and parts, (6) against the reality and extreme rigour of the struggle for existence and personal selection (an essential. foundation of the selection theory), (7) against the sexual selection theory, particularly in its capacity as a supporting prop of the natural selection theory, ( 8 ) against the reliance by the selectionists on the homology or analogy which they hold to exist between natural selection and artificial selection, and finally to consider those curiously positive and definite declarations of such radical anti-Darwinians as Wolff, Korschinsky, and others that natural selection is a vagary, having no claims to existence either on a basis of 
observation or logical reasoning, or that if it exists its whole influence is directly inimical to changes and evolution rather than of a nature to produce and foster them. The most comprehensive, fairest, and most effective recent attempt to gather together and meet seriatim the objections and criticisms of Darwinism is (as already stated in the chapter on "Darwinism Attacked") that of Ludwig Plate," and I have therefore given considerable space in this chapter to direct quotations from the answers and discussions of this modern Darwinian champion.

The objection made that natural selection can make no use at all of the small fuctuating Darwinian variations is really

Answer to the objection that fictuating variations are too slight to be of selective value. a wider application of the really valid objection that such variations cannot, or can only rarely, offer material for the production by selection of new organs and that for many adaptations they are too slight to be of use and hence cannot serve as handles for selection. As a matter of fact, however, many adaptive modifications are purely quantitative, not necessarily involving any qualitative change at all. Increase in general size, or in any one dimension of an organ or part, meaning often an increase of strength on the part of the animal, in the capacity for aggression or defence, in swiftness, in flight, running or swimming, in reaching or digging or climbing or leapingsuch an adaptive modification might well be brought about by selection of even very inconsiderable enlargements or strengthenings of one or more organs or parts. Wherever the modification is in a directly linear path, and an advantage is possible through even slight advances or regressions along this line, natural selection will find in the Darwinian variations a means of fostering and perfecting this modification. There are just two requirements necessary for the Darwinian variations to meet in order to serve as handles for natural selection: they must be variations actually suffi- 
ciently useful and advantageous to turn the scale in the intraor inter-specific struggle for existence in favour of the individuals possessing them, and they must occur in sufficiently many individuals to avoid being swamped or extinguished by cross-breeding : that is, they must be useful enough to be selected and numerous enough to perpetuate themselves. Do Darwinian variations ever meet these requirements? Unfortunately our proof is rather indirect: observation reveals their abundance, but does not actually show their utility. To answer the question our judgment and reason, based on our knowledge and experience of the existing conditions of animal and plant life, will have to be trusted for answer. How real is the rigour; how keen the struggle; how crowded the square yard or square mile; how great or how little must be the differences in a part to give a life-or-death decision in the competition? Each naturalist must answer this for himself, and the layman must take the general consensus of opinion of the naturalists, if there is one, for his answer.

The objection to the linear and quantitative character of the Darwinian variations has been recently especially urged by de Vries in connection with his exposition

Answer to the objection concerning the linear and quan. titative character of fluctrating variation. of the theory of species-forming by mutations. The selection theory reckons with linear hence strictly quantitative variations, says he, and yet is presumed to create new forms for which in reality qualitative variations are necessary as a basis, so that in fact selection can only increase or diminish, add to or subtract from characters already in existence and cannot create anything new, this appearance of new characteristics being, however, precisely the principal peculiarity of new species, taken by and large. This position of de Vries has been discussed by Plate ${ }^{2}$ as follows: "I call attention in advance to the fact that de Vries understands by 'linear variations' what are more usually 
known as individual, fluctuating or continuous variations. He has chosen this name because the single characteristic can change toward but two directions; that is, toward the plus, or toward the minus direction. In contrast to this kind of variation stand the sudden and discontinuous leaplike changes or mutations which have been for the first time carefully investigated by the praiseworthy labour of de Vries, hitherto having been familiar indeed under the names 'single variations' or 'sports,' but little studied. Concerning these linear variations de Vries writes: 'The statistical method of the study of variation has now been so generally followed as to make its principles familiar without further discussion, and they may be considered as accepted. The chief principle indicated by the use of the frequency curves is that the characteristics vary in but two directions, that is toward plus or toward minus. The old vague conception of an all-sided variation of the single characters has disappeared of its own self.'

"As highly as I appreciate the great service of de Vries in relation to our knowledge of the suddenly appearing changes, heritable in high degree, I must nevertheless oppose him in his conclusions touching the selection theory. In the first place this theory does not reckon alone with linear variations, but also with mutations, if they appear, for it takes the changes as given material without troubling itself about differences in their mode of origin. In the second place it is not correct that a character cannot so change itself through simple addition or reduction that it may not be, in the customary classificatory limits, looked on as a new character. A smooth leaf, a leaf with few small hairs, and one with a thick wool show only linear variations, but in spite of that they may very well serve as characteristic of different species. Nearly related butterflies-recall the Vanessas and Lycænas-often show the same fundamental characters of pattern and form, so that they are dis- 
tinguished only by plus or minus variations. Indeed one may consider the whole endless manifoldness of organic combinations as only representing greater or lesser numbers of atoms of the same few elements which are bound together in one molecule. In the third place the statistical studies of variation have not shattered in any respect the conception of an all-sided variation of the single characters, but indeed on the contrary have rather shown that all the parts and attributes of organisms that are accessible to observation appear to us more or less different in different individuals. This all-sided variability has nothing to do with the statement that each single variable element can vary always only toward plus or toward minus. Blue flower petals can appear more or less blue and at the same time reveal their indeterminate, fortuitous, or all-sided variability in differences of form, hairiness, thickness, structure, etc. The same indeterminateness which de Vries claims for his mutations is characteristic also of linear variations."

Tayler, a Darwinian defender, has discussed this objection as follows: "This objection appears to me to be one of the most weighty of all the objections which have been raised to the selectional hypothesis, and it is further an extremely difficult objection to satisfactorily reply to ; first, because it is almost impossible to say in what form of organism the earliest variations appeared, and without this no judgment on the value of any small variation can be of use; secondly, it is equally essential to know the kind of environment which * such an organism was living in; and lastly, if we were fully acquainted with the character of the organism and its environment it would still be difficult to form any adequate opinion on the value of such a variation, owing to the fact that this apparently simple organism would differ so widely from our own functional activity and life that any conclusions formed on comparative methods of testing its powers, 
etc., would be extremely likely to be fallacious. If, however, we keep in mind the facts that ( $\mathrm{I}$ ) the whole and not merely a part of the organism is selected, and that, therefore, each variation does not require to be of the same value as if selection depended on it alone; (2) specialisations are largely quantitative, between man at one extreme of development and a simple unicellular organism at the other, the difference, though very great, is mainly due to the fact that man is a huge multicellular colony; this difficulty will be much simplified. To estimate the quantitative difference it is necessary to endeavour to determine the specialisation of an individual cell in one of those collective specialisations or organs: the difference between a cell in, for instance, the cerebral cortex of man and the character of an amœba is no doubt great, but the amceba reacts to stimuli, though in a less specialised form, just as the cortex cell does; in the same way the reaction to light in the mammalian eye is not a new development-it has its beginnings in the preference for light or darkness shown by many unicellular organisms. These two points, that selection is organismal and that specialisations are as, or more, largely quantitative than qualitative, weaken if they do not abolish all those diffculties to natural selection that are founded on this objection, and it is further necessary to recollect that no specialisation has yet been found which has not a primitive counterpart in the earliest known forms of life."

With regard to the objection that because natural selection working with fluctuating Darwinian variations is working only with linear or quantitative variaAnswer to the tions and therefore cannot produce manyselection cannot branched descent (which is certainly the kind produce many-
branched descent and discontinuity mono-typic descent, it is obvious that the Darin series.

winian answer to this is partly that of the answer to the objection discussed in the last paragraph. In 
addition it is partly that of the answer to the objection to be mentioned in the next sentence. This related objection is that while natural selection may produce continuous gradatory adaptive change or evolution it cannot produce discontinuity in the series, $i$. c., cannot produce separated distinct species. This objection receives an answer which is of the nature of an admission that natural selection wholly unaided really cannot differentiate species. It must call to its aid some isolation or segregation factor, and as isolation is certainly most commonly effected through migration and geographic means, it is usually this factor of geographic isolation that natural selection must be accompanied by to form new species. As Plate says: "Any particular phase of the struggle for existence extinguishes all those individuals which do not possess certain absolutely necessary characteristics. By this means there is produced a common type. And only when some means of isolation is added can the splitting of the species into two or more forms result. Natural selection can only transform a species gradually and develop it in a continuous forthright line; alone it cannot produce a divergent, tree-like evolution. This results from geographic, biologic, or sexual isolation, which is in most cases a form of the extensive manner of working of the struggle for existence. But selection can aid in the differentiation of a species into two or more forms, as the following examples show. When all average or median-sized individuals of a species are killed out there remain only the smallest and the largest, by which we may assume that the first are saved because they can most readily conceal themselves, while the latter find in their great size a sufficient protection. On the ground of this difference in size perhaps both forms will be inclined to keep apart from each other and if to this is added a somewhat differing habit of life, two races can arise which in course of time will become distinct species. From a butterfly kind of very variable 
colour-tone all brown individuals might disappear for some special reason while both the lighter and darker individuals might persist. Now if in consequence of this contrast a racial feeling should develop between the light individuals on the one hand and the dark ones on the other, the differentiation into two species is already begun. If a snail species living in fresh water is so harassed that it can only maintain itself when its individuals move either into the region between tide-lines or into the deeper water, this would lead to morphological differentiation, as we can indeed actually note in the case of the chitons."

The objection that the existence of coadaptive and highly complex adaptations, especially those which seem as if they could be of no possible advantage to their posAnswer to the sessors except in their present fully developed
objection concerning complex and correlated adaptations.

or specialised state, is one which unfortunately cannot be definitely refuted or proved by ever so much ingenious explaining or discussion in the face of the lack of what we certainly do not now possess, namely, direct observational or experimental evidence. For such specialisations as elaborate mimickry, or the electric organ of the torpedo, etc., which are of apparent advantage only in perfected state, the selectionist is forced to admit that the objector has apparently a good case, but for the gradual specialisation of many highly complex structures and specialisations through the long-continued selection of slight advantageous variations, Darwin and his followers have offered ingenious and plausible explanations. For the case of so complex and coadaptive a specialisation as the eye and its function in the vertebrates or in the insects and crustaceans, the possible evolution, by slight additions and modifications, from simple pigment fleck to the present marvellous visual organ, a logically irrefutable Darwinian argument can be made out on the basis of the real and constant utility and advantage of even very slight steps 
forward. And so with many other complex specialisations, although in almost all these cases it is necessary, as Darwin says, to let the reason conquer the imagination. That is, the reasoned explanation explains, although one recoils constantly before the almost inconceivable actuality of the phenomenon.

Plate has recognised this objection as one of the really weighty ones and has given much attention to its consideration. His conclusion is that it is necessary to rely to a greater or less extent on the Lamarckian factor of the inheritance of somatogenic characters acquired in the lifetime of the individual through the effects of use, or disuse, or other functional stimuli. This is, of course, direct abandonment of the position maintained by such strict selectionists as Weismann and Wallace, although Weismann himself, in order to answer the objection without having recourse to reliance on Lamarckian factors, introduces his new theory or hypothesis of germinal selection to aid natural selection in the difficulty presented by the objection. Lloyd Morgan's ' answer to this objection consists chiefly of the formulation of the theory of orthoplasy (explained in chapter viii of this book). It is, briefly, that every organism, from its somatic and germinal aspects, exhibits two tendencies of variability. The somatic variability is determined largely or at least modified largely by environmental infuences; therefore those organisms whose somatic tendency is predominantly plastic will survive under altered conditions of environment, where those organisms of a less easily modifiable tendency will be eliminated. Now if somatic changes rarely or never become germinal, i.e., are inherited, the modifications of the parental organisms cannot be transmitted to their offspring, but those offspring that happen t $\omega$ be endowed with germinal variations in the same direction as the acquired but not transmitted modifications would start their life with a predisposition favourable to their 
environment and therefore favourable to more complete modification of the somatic side of the organism; this tendency being accumulative under constant conditions, coincident variability would arise by the process of selective elimination and preservation, without the need of the assumption of use-inheritance, which assumption facts appear to negative.

Against the criticism that natural selection cannot explain over-developments of specialisation, that is, the carrying

Answer to the objection concerning overspecialisation.

unnecessarily far of advantageous structural and functional development, as illustrated by the great antlers of stags and moose, the microscopic fidelity of simulation and mimicry, and the nearly identical equivalence of the right and left halves of bilaterally symmetrical animals, the selectionist has little to offer except the always pertinent questions: Are we sure that the case in point is one of over-development, of unnecessary specialisation? And although the palæo-zoologists may be pretty emphatic in their declarations that the extinction of the Irish stag and of the unwieldy cretaceous reptiles was directly due to over-specialisation, they cannot prove it. And there you are, says the Darwinist.

The difficulty that natural selection has with structural degeneration is admittedly a real one. The strict Darwinian

Consideration of the objection concerning degeneration. answer has to be that retrogression is produced either by reversed selection, that is, that when by a change in the life habits or external conditions a certain function or organ becomes injurious, as in the case of insects on small exposed islands where the wind might carry the flying ones off into the ocean, selection, on the basis of advantage, would tend to preserve the ones most poorly equipped for flight; or it has to be that when the function of an organ is, because of change in habit or conditions, once neglected or discontinued, that is, the organ is no longer used, any slight varia- 
tion toward reduction of the organ would be of advantage because of the saving in food which would be effected! But this is simply carrying the logic of the principle of advantage to an illogical extreme, an extreme impossible to accept. So Weismann devised the ingenious explanation of panmixia or cessation of selection to account for degeneration. That is, a rigid and persistent selective activity is as necessary to maintain a specialisation as it was to produce it. But even Weismann has found this explanation inadequate and has, therefore, found a final and sufficient explanation in his new theory of germinal selection. This last theory, a refinement of Roux's theory of the battle of the parts, is ingenious, suggestive, and thoroughly interesting, but unfortunately it is founded on certain assumptions concerning the ultimate make-up of the germ-plasm and the behaviour of the unit parts of it, the truth of which simply cannot be tested. A strictly neo-Darwinian answer, that is, one based solely on selection, is therefore hard to give. Plate, ${ }^{10}$ after an effective adverse criticism of the influence of the Weismannian panmixia as an explanation of the structural reduction or atrophy of parts, concludes that such reduced or rudimentary organs are to be explained "through the inherited effects of disuse, the inherited effects of the influences of external factors, the inherited effects of the influence of economy in nutrition, and, in a few cases, through reversed selection. The first three principles are cnly admissible under the assumption of the actuality of the inheritance of individually acquired characters, and the fourth principle has only a very subordinate importance." This is equivalent to saying that the strict selectionist has no sufficient answer to the objection under present consideration. One seems forced to rely on Lamarckian factors for anything like a satisfactory explanation of actual structural reduction of useless organs. Tayler, ${ }^{11}$ however, offers an explanation for both ontogenic and phyletic degeneration, based on the 
"known facts of nutrition." The interested reader may find this explanation in the appendix to this chapter.

Doubt is expressed by some biologists of the reality and fierceness of the struggle for existence which is an essential

Answer to the objections urged against the rigour of selection. part of the selection theory. De Vries expresses the belief that the intra-specific struggle, that is, the struggle and competition among individuals of the same species, has been much overrated. And a few observations ${ }^{12}$ have actually been made which indicate that for certain species this struggle is at least not rigorous enough to give to the slight Darwinian variations a determining value as to the character of the surviving individuals. Here again the proof for the Darwinian point of view is not one so much of observation-although actual life-and-death combats between individuals of a single species, and innumerable examples of the preying of one species on another are familiar-as it is a proof of reasoning. The fact of an over-production of eggs and embryos, that is, of reproduction by multiplication, is undeniable. The lack of existing space and food for all individuals, if all should live the ordinary span of life peculiar to the species, is demonstrable by mathematics. The consequent conclusion of these two established premises is a struggle for existence. That is the sound Darwinian position.

The principal answer of the Darwinians to the criticisms levelled at the theory of sexual selection is, that however ineffective the theory is to explain many of the Answer to the objections to the sexual selection theory.

phenomena it is called on to cover, it is at least so much more reasonable and satisfying as an explanation of some of the phenomena, that is, some of the categories of secondary sexual characters, such as the ornamental plumes and colour-patterns of birds, the sound-making organs of insects, etc., than any alternative explanation that has been offered, that until a better expla- 
nation be presented the theory of sexual selection should not be discarded. That no other explanation of many, if not most, of the phenomena in question has anything at all convincing or satisfactory about it, or has met with any general acceptance on the part of naturalists, is the plain truth. If we feel it imperative to give our adherence, with certain reservations, to any explanatory hypothesis of secondary sexual characters, Darwin's theory is the one to have first claim on us. As a matter of personal opinion I feel no necessity for any such attitude and am willing to look on most of the phenomena connected with the general problem of secondary sextial characters as quite inexplicable on the basis of our present knowledge of bionomics.

The specific answer of Lloyd Morgan ${ }^{13}$ and other Darwinians to the objection that choice on the part of the female assumes an æsthetic recognition and preference which it is doing violence to our knowledge of animal psychology to assume, should not be overlooked. This answer is, put summarily, that this so-called choice is one of impulse, not deliberation: it is an imperative reaction to a sufficient stimulus: and what determines that the stimulus from one male shall be sufficient while that from another is not, is the degree of pronouncedness or effectiveness of the ornament, or call, or behaviour. It is a choice "which is determined by the emotional meaning of the conscious meaning. And it is the reiterated revival of the associated emotional elements which generates an impulse sufficiently strong to overcome her instinctive coyness and reluctance. ... It is a perceptual choice arising from impulse rather than an ideational choice due to motive and volition."

Regarding Wolff's argument that an explanation of these characters is very necessary to the acceptance of the theory of natural selection there is little to say in rebuttal. Natural selection confesses itself inadequate to explain those extraordinary characters and conditions by which the males 
of many species of mammals, birds, insects, spiders, etc., differ from the females. And if sexual selection does not explain them then some other explanation is necessary. But the lack of this explanation does not invalidate the general theory of natural selection as one of the factors in organic evolution and indeed one of the most important and farreaching ones.

The difficulty of a satisfactory discussion of the objection that natural selection rests too largely on an assumed likeness to artificial selection, while the differences in

Consideration of the objection that natural selection rests too largely on an assumed analogy several thousand years through which artificial with artificial selection.

the two processes, especially in their results, are too radical to allow us to rest any confidence on this apparent homology, is, that despite the selection has been followed and studied we still know too little of the real character of it, especially of its results. Most selectionists now admit that the argument for natural selection on the basis of its similarity to artificial selection has been given too great prominence and relied on too strongly, but that the observed processes of the one do teach us much of truth about the unobservable processes of the other the Darwinians firmly maintain. As Plate says, "The great value of artificial selection consists in this, that it shows first, that a gradual cumulation of characteristics in definite directions is actually possible through successive selections, and second, that it has afforded us a rich mass of data concerning variation, inheritance, and the influence of changing intrinsic conditions or influences. When Darwin showed what a high plasticity the domestic animals possess he built for his theoretical explanation of descent an indubitable necessary foundation, for the changes which a domestic animal passes through in the hands of man must of necessity be able to be called forth in similar manner in the feral animals by the creative force of nature, for the domestic animals cer- 
tainly have come from the wild ones. It is also true that man has made use of only natural factors, and whoever will compare the extraordinary creatures of the deep sea with even the most bizarre of our cultivated races, will see that the fluxing life-conditions of free nature can modify or reform the animal world in no less degree than the intelligence of man can do it. .. .

"Recently de Vries, ${ }^{14}$ in his book on 'Mutations,' has tried to deny the worth of the selection principle, and although I fully recognise the high worth of his contribution to science based on such extensive series of experiments, yet I must oppose him in this position. In various places in the book he writes that nothing fixed can be produced by selection, and that therefore it can have no importance as a working factor in descent. For example, in the introduction (p. 6) he says: 'Artificial selection never, as far as experience reaches, leads to the origin of new complete types.' The reversion of modified domesticated races is indubitable, and de Vries himself has brought forward new illustrations of this fact which has been so long known. But convincing proof that natural selection cannot lead to constant forms cannot be deduced from these observations, because they refer in all cases to forms which have been highly modified in the course of a few years or decades, so that the presumption lies close at hand that there has not been sufficient time really and lastingly to modify the original heredity established by centuries. Many facts indicate that the intensity of heredity depends upon the number of generations, that is, upon time. Long-inherited characters are difficult to eradicate; recent ones easy. We can, therefore, not expect to meet such a constancy in the products of a century as we find in Nature. Many gradually selected races of doves are now almost entirely constant, that is, no longer revert to the primitive race when they are inter-bred. The way in which the reversions appear shows that the duration 
of time plays an important rôle in inheritance (heredity). Schubeler found in his studies of the translation of the northern boundary of the grain culture that the characters newly acquired (heavier and earlier ripening seeds) persisted for several generations when the forms were replanted in the original [more southerly] habitat. De Vries in six years selected corn which had an average of 20 rows of kernels instead of the original I 2 to 14 , and held the plants at this height of production through five years. When he then planted seed from a I6-rowed ear, the average of the ears gathered from this planting was in the first generation still at 20 rows, and sank only in the next two years again to I4 to I6. If he had continued his selection longer he would have arrived at a more nearly constant form. De Vries himself says: 'When the selection ceases, the selected characteristics drop away and in practically the same length of time which was necessary for the production of the new race, that is within a few generations.' From this it follows that a domestic race produced by slow persistent selection through many thousands of generations would show the same relative constancy or fixity as natural species, the majority of which also must have originated slowly, for otherwise the appearance of new species would be often observed. If one wishes to be very conservative in this matter one may declare: in the light of our present knowledge we cannot say that artificial selection gives us any safe means of judging just what degree of constancy [fixity] can be attained by its means; but it is not fair to say that because up to the present only a partial constancy has been reached through artificial selection, natural selection cannot have led to the production of constant species. All cultivated races have been relatively quickly, some indeed very quickly, selected ${ }^{15}$ and, therefore, they strike back very quickly. This, however, need not be assumed for the slowly arisen products of natural selection." 
Tayler, ${ }^{16}$ making a general defence of the natural selection theory, says: "To realise how far the theory of selection is

Tayler's gencapable of explaining the facts of organic evoeral defense of lution, it is necessary to bear in mind the natural selection. postulates on which the theory is founded.

"I. It is obvious that natural selection can only act by preserving or eliminating the complete organism. Selection must therefore be organismal. This Darwin and other selectionists have clearly recognised.

"2. As the whole organism must survive, if the favourable variation or variations are to be preserved, it follows that certain minor unfarourable variations may also be preserved if they happen to exist in an individual which survives on account of its major favourable variations. And since no individual is completely adapted to its environment, it follows that there must be always a variable amount of residual unfavourable variability in every organism.

"3. This residual unfavourable variability may be of considerable utility under changed conditions.

"4. Complementary specialisation of parts, as Spencer has shown, is favourable to successful competition, and as it is the whole organism that is selected or eliminated, it follows that any weakness of one specialised part, since it would disturb the balance of all, would be detrimental. The more complex the organism, the more specialised the structures, the more dependent one part will be on the others for its existence, hence a complementary specialising tendency will be favoured by selection, and therefore all struggles of one part of an organism with another will be reduced to a minimum.

"It is clear that there must be some underlying criterion which determines whether any given organism shall be selected or not, and that criterion must be the net result of its adaptability to its environment. One organism may conceivably survive, by its possession of a large number of smalf 
favourable variations, while another may survive in virtue of a single valuable one, but in each case it would be the whole walue of that organism which determined its survival. This fact is continually disregarded by opponents of the neo-Darwinian position, yet this selection of the organism as a whole is the fundamental postulate fron which the theory of selection starts. Thus it is not uncommon to read criticisms bearing on the early development of some organ, in which the inadequacy of selection is supposed to be proved by the writer demonstrating, or beiieving he has demonstrated, the fact that the particular variation in question must have been too small to be by itself of selection value. In many cases the particular variation would, no doubt, if taken alone be, as the objector asserts, too unimportant to be selected, but as it is the whole organism that is selected, it is not logical to make an artificial separation and study the development of one organ or structure irrespective of the other organs with which it is in nature associated. Every organ in its ciolution must be considered in relation to the alhole of the particular organism in which that particular stage of development of that organ is found. Starting, therefore, with this fact that the net value of adaptability of the whole organism to its environment must be the basis which determines selection or elimination, it will follow that certain lines of development will result from the application of this criterion. In a series of organisms placed under new conditions, elimination will proceed along lines essential to bring about a proper adjustment to the new conditions. If the offspring of these adjusted organisms merely repeated in their generation the characters of the exterminated as well as of the surviving organisms, that temporary adjustment would be permanent as long as the conditions were unchanged. But since the offspring are produced only by the surviving organisms, selection is continually raised to higher and higher planes of adaptation. 
and, therefore, as long as conditions remain constant, the tendency of selection must be, as Darwin clearly saw, cumulative. He did not, however, apparently see that from this cumulative tendency definite variability must arise out of indefinite.

"Selection in direct relation to climatic conditions is, therefore, of very minor importance, while selection among the members of a species and all forms of inter-organismal selection is of infinitely more importance, since it is this interaction, produced by the offspring in different degrees inheriting the advantages of both parents (both of whom have survived on account of certain advantages), that leads to the cumulative development and never-ending struggle for survival. Darwin came very near to this conception of definite variability when he pointed out that if a country were changing the altered conditions would tend to cause variation, not but what I believe most beings vary at all times enough for selection to act on.' Extermination would expose the remainder to 'the mutual action of a different set of inhabitants, which I believe to be more important to the life of each being than mere climate,' ${ }^{*}$ and as 'the same spot will support more life if occupied by very diverse forms,' it is evident that selection will favour very great diversity of structure.

"Bearing in mind this cumulative action of selection it will follow that under constant or relatively constant conditions the struggle for successful living will become more and more selective in character, even if the actual number of inhabitants remain more or less the same as when the struggle first commenced. The selection of variations will thus tend to pass through certain more or less ill-defined, but nevertheless, real stages. In proportion as the struggle becomes intense, either from the number or from the in-

*From Poulton's "Charles Darwin and the Theory of Natural Selection" (Abstract of Darwin's letter to Professor Asa Gray). 
creasing adaptability of the organisms, or both, certain major essential adaptations, which were necessary for the climatic and other more or less comparatively simple conditions, will be supplemented by minor auxiliary variations which in the earlier stages would not have appeared. And still later, as more and more rigorous conditions of life were imposed, the advantage would tend to rest with those organisms which possessed highly coördinated adaptations, since this would entail more rapid responsiveness to environment.

"As evolution advances from the unspecialised to the specialised, and higher and higher forms of life come into being, with increasing complexity and specialisation of parts entailing an increasingly delicate adjustment of those parts to each other's needs, the relation of each part to the whole organism becomes of more and more importance, and it follows that selection must become more and more generalised in its action. No single variation could be of service to any of the higher forms of life unless it was in more or less complete harmony with the whole tendency of the individual. The adjustment of parts and their mutual interdependence make it essential for adaptation that the relation of parts be preserved: consequently, correlated minute favourable variations will tend to be more and more selected as evolution passes from the unspecialised to the specialised forms of life. This response of the whole organism should be still more delicate in those forms of life that are continually subjecting themselves to changed conditions; hence this delicacy of adjustment is far more necessary in the higher forms of animal life than in the more stationary plant organisms, and in the developing nervous system of animals we have just the central adjusting system that is required for these conditions. With evolution of type there aill thus be an increasingly definite tendency given to organic, especially the animal, forms of life, if the acting principle of evolution has been sclectional. Selection is, therefore, able 
to account for the steadily progressive tendency of life as a whole without calling to its aid any unknown and doubtful perfecting principle.

"To summarise:-Natural selection, acting on the whole organism, tends to produce more and more definite tendencies in all surviving forms of life, which tendencies are progressive and continuous in character. Variable conditions, by partially altering the line of selection, induce a temporary indefiniteness. And lastly, the process of selection being itself able to be the indirect, though not the direct, cause of those favourable variations, which it subsequently selects from, is able to dispense with any subsidiary factors, provided it has a certain number of elementary properties of life which afford sufficient material to work with."

\section{APPENDIX.}

"Semper, Carl, "Der Haeckelismus in der Zoologie," I876.

"In I876. Gustav Jaeger anticipated Weismann's later muchheralded theory of the continuity of the germ-plasm in his "Zoologische Briefen."

${ }^{3}$ For an excellent detailed critical account of these general, as well as the several accessory theories (amphimixis, polar bodies, etc.) of Weismann, see Romanes's "An Examination of Weismannism." I893.

"It is of interest to note that the strongest defenders of neoDarwinism to-day are the English naturalists. Americans mostly lean toward neo-Lamarckism; the Germans are divided.

${ }^{5}$ Plate, Ludwig. "Uber die Bedeutung des Darwin'schen Selectionsprinzip und Probleme der Artbildung," 2d ed., Ig0.3.

${ }^{6}$ Prof. Weldon, an English Darwinian, has recorded (Nature, Sept. 22, 1898) an extremely interesting and much discussed statistical and experimental study of the presumable action of natural selection working on slight fluctuating quantitative variations. "I can only attempt to discuss," says Prof. Weldon, "the importance of small variations, and the rate of organic change, in the one case which I happen to know. The particular case I have myself studied is the variation in the frontal breadth of Carcinus monas [a small shore-crab]. 
"During the last six years my friend, Mr. Herbert Thompson, and I have studied in some detail the state of this character in the Weldon's ex- small shore-crabs which swarm on the beach below periments on Carcinus, the laboratory of the Marine Biological Association, at Plymouth.

"I will show you that in those crabs small changes in the size of the frontal breadth do, under certain circumstances, affect the deathrate, and that the mean frontal breadth among this race of crabs is, in fact, changing at a rate sufficiently rapid for all the requirements of a theory of evolution.

"In Table IV [omitted], you see three determinations of the mean frontal breadth of these crabs, expressed in terms of the carapace-length, taken as 1,000 . You see that the mean breadth varies very rapidly with the length of the crab, so that it was necessary to determine it separately in small groups of crabs, such that the length of no two crabs in a group differed by more than a fifth of a millimetre. The first column of the table shows you the mean frontal breadth of twenty-five such groups, between 10 and I 5 millimetres long, collected in 1893 . These crabs were measured by Mr. Thompson. The second column shows you the mean frontal breadth in twenty-five similar groups of crabs, collected in 1895 , and also measured by Mr. Thompson. You see that in every case the mean breadth in a group of crabs collected in 1895 is less than it was in crabs of the same size collected in 1893 . The third column contains the result, so far as it is yet obtained, of my own measurement of crabs collected this year. It is very incomplete, because the I895 crabs were collected in August and September, and I was anxious to compare them with crabs collected this year at the same season, so that there has not yet been time to measure the whole series. The measurements are sufficient, however, to show that the same kind of change has taken place during the last three years as that observed by Mr. Thompson in the interval between I893 and 1895. Making every allowance for the smallness of the numbers so far measured this year, there is no doubt whatever that the mean frontal breadth of crabs from this piece of shore is considerably less now then it was in 1895 among crabs of the same size.*

"These results all relate to male crabs. The change in female

* I shall, of course, consider it my duty to justify this statement by more extensive measurement as soon as possible. In the meantime I may say that I have measured other small groups of crabs, male and female, from the same place, at different seasons of the years $1896-98$, and the results agree with those recorded in the table. 
crabs during this time has been less than the change in male crabs, but it is, so far as my measurements at present permit me to speak, going on in the same direction as the change in male crabs.

"I think there can be no doubt, therefore, that the frontal breadth of these crabs is diminishing year by year at a rate which is very rapid, compared with the rate at which animal evolution is commonly supposed to progress.

"I will ask your patience for a little while longer, that I may tell you why $\mathrm{l}$ feel confident that this change is due to a selective destruction, caused by certain rapidly changing conditions of Plymouth Sound.

"On either side of Plymouth itself a considerable estuary opens into the Sound, and each of these estuaries brings down water from the high granite moorlands, where there are rich deposits of china clay. Those of you who know Dartmoor will remember that in rainy weather a great deal of china clay is washed into the brooks and rivers, so that the water frequently looks white and opaque, like milk. Much of this finely divided china clay is carried down to the sea; and one effect of the breakwater has been to increase the quantity of this fine silt which settles in the Sound itself. instead of being swept out by the scour of the tide and the waves of severe storms.

"So that the quantity of fine mud on the shores and on the bottom of the Sound is greater than it used to be, and is constantly increasing.

"But this is not all. During the forty or fifty years which have gone by since the breakwater was completed, the towns on the shores have largely increased their population; the great dockyard at Devonport has increased in size and activity; and the ships which visit the Sound are larger and more numerous than they were. Now the sewage and other refuse from these great and growing towns and dockyards, and from all these ships, is thrown into the Sound; so that while it is more difficult than it used to be for fine silt to be washed out of the Sound, the quantity thrown into it is much greater than it was, and is becoming greater every day.

"It is well known that these changes in the physical conditions of the Sound have been accompanied by the disappearance of animals which used to live in it, but which are now found only outside the area affected by the breakwater.

"These considerations induced me to try the experiment of keeping crabs in water containing fine mud in suspension, in order to see whether a selective destruction occurred under these circumstances or not. For this purpose, crabs were collected and placed in a large vessel of sea-water, in which a considerable quantity of very fine 
china clay was suspended. The clay was prevented from settling by a slowly moving automatic agitator; and the crabs were kept under these conditions for various periods of time. At the end of each experiment the dead were separated from the living, and both were measured.

"In every case in which this experiment was performed with china clay as fine as that brought down by the rivers, or nearly so, the crabs which died were on the whole distinctly broader than the crabs which lived through the experiment, so that a crab's chance of survival could be measured by its frontal breadth.

"When the experiment was performed with coarser clay than this, the death-rate was smaller, and was not selective.

"I will rapidly show you the results of one or two experiments. The diagram [omitted] shows the distribution of frontal breadths, about the average proper to their length, in 248 male crabs treated in one experiment. Of these crabs, I54 died during the experiment, and 94 survived. The distribution of frontal breadths in the survivors is shown by the lower curve in the diagram, and you see that the mean of the survivors is clearly below the mean of the original series, the mean of the dead being above the original mean.

"Two other cases, which are only examples of a series in my possession. show precisely the same thing.

"These experiments seemed to me to show that very finely divided china clay does kill crabs in such a way that those in which the frontal breadth is greatest die first, those in which it is less live longer. The destruction is selective, and tends to lower the mean frontal breadth of the crabs subjected to its action. It seemed to me that the finer the particles used in the experiments, that is to say, the more nearly they approached the fineness of the actual silt on the beach, the more selective their action was.

"I, therefore, went down to the beach, where the crabs live, and looked at the silt there. This beach is made of moderately small pieces of mountain limestone, which are angular and little worn by water. The pieces of limestone are covered at low tide with a thin layer of very fine mud, which is much finer than the china clay I had used in my experiments, and remains suspended in still water for some time. Under these stones the crabs live, and the least disturbance of these stones raises a cloud of very fine mud in the pools of water under them. By washing the stones of the beach in a bucket of sea-water, I collected a quantity of this very fine mud, and used it in a fresh series of experiments, precisely as I had before used china clay, and I obtained the same result. The mean frontal breadth of the survivors was always smaller than the mean frontal breadth of the dead. 
"I think, therefore, that Mr. Thompson's work, and my own, have demonstrated two facts about these crabs; the first is that their mean frontal breadth is diminishing year by year at a measurable rate, which is more rapid in males than in females; the second is that this diminution in the frontal breadth occurs in the presence of a material, namely, fine mud. which is increasing in amount, and which can be shown experimentally to destroy broad-fronted crabs at a greater rate than crabs with narrower frontal margins.

"I see no shadow of reason for refusing to believe that the action of mud upon the beach is the same as that in an experimental aquarium; and if we believe this, I see no escape from the conclusion that we have here a case of Natural Selection acting with great rapidity, because of the rapidity with which the conditions of life are changing."

These observations and conclusions of Professor Weldon have been the subject of much discussion. The adverse criticism has, on the whole, seemed to be successful in discrediting the case as an example of any such clear-cut action of natural selection, as Weldon seems to hold it to be. J. T. Cunningham (Natural Science, Vol. XIV, pp. 38-45, I899) concludes, after a critical analysis of the work, that "Weldon's observations may be completely explained by variations in the amount or rate of growth. The difference in different years would be at once explained if the amount of change in frontal breadth was constant for each moult, while the amount of growth was variable. The fact is, that in 1893 crabs of a given frontal breadth were larger than in 1895 and I898; and I have shown that the summer of 1893 was exceptionally fine and warm. Either the warmth alone, or warmth and food together, very probably made the crabs grow more in that year for the same number of moults. On this view the broad-fronted crabs died in the experiments with clay and mud because they were younger and weaker. In the same way the crabs that moulted in the bottles possibly grew more than those in the sea, because they were kept in warmer water and supplied with more food. Therefore they were, after the moult, larger than those in the sea of the same relative frontal breadth.

"The change described is not. if terms are used correctly, a change in the character of the species, but merely a change in the rate of development. The variations investigated are not individual differences, since each individual in the course of its growth passes through each one of the variations in its own person. It has not been shown that the change has gone on continuously for five years, or that it has taken place only in waters where there is much mud. If tadpoles of the same size were found to have shorter tails 
in one year than in another, few biologists would draw the conclusion that the result was due to the selective destruction of those with the longest tails. The more probable explanation would be that those with the shorter tails were in a more advanced stage of their metamorphosis."

7 Plate, L., "Über die Bedeutung," etc., pp. 3I-32, I903.

${ }^{8}$ Tayler, J. L., "The Scope of Natural Selection," Nat. Science, Vol. XV, pp. I I4-129, I899.

"Morgan, C. Lloyd, "Factors in the Evolution of the Mammalia," Nat. Science, pp. 97-IOI, I892.

${ }^{10}$ Plate, L., "Über die Bedeutung," etc., pp. I59-I60, I903.

${ }^{11}$ Tayler, J. L., "The Scope of Natural Selection," Nat. Science, Vol. XV, pp. II4-I29, I899. I quote as follows: "In the development

Tayler's ex- of the individual we see a disappearance of structures, planation of de- which appear to become, with advancing development, generation by useless, almost parallel to the gradual disappearance of natural selection. rudiments, etc., in the history of the species evolution. And a common explanation for both of these series of phenomena can, I believe, be satisfactorily found in the known facts of nutrition. Growth of any tissue would seem to depend on three conditions, a stimulus of the part adequate to promote functional activity, a proper food supply, and efficient removal of products produced by that particular tissue's activity. There is abundant evidence to prove that a tissue tends to degenerate if its own excretory products are not removed; the evil effects produced by fatigue products in muscle and other tissues on the activity of the tissue itself, prove that this factor must be of great importance whereever it is found to occur. Just as the growth and development of bacteria are interfered with, and finally altogether checked by the accumulation of products of their own activity, so a tissue in the higher organisms has its activity impaired and its power lessened when for some reason diminished elimination of its own metabolic products occurs. Now both in the development of the individual and the race we see an alteration of structure, a gradual transition from the less to the more specialised, and in this gradual transition there must be, as I endeavoured to prove in my answer to the last objection, an alteration in the line of functional activity of the parts, and that, owing to this fact, a tissue that was necessary in the earlier stages became less and less so as specialisation advanced, the whole tendency of the specialising organism being continually and increasingly against the earlier, less specialised, stages. It will thus happen that every structure which is becoming useless. owing to its deficient specialisation, whether in the history of the race or the individual, will have two adverse sets of conditions to contend 
with-one, defective elimination of its own tissue products, owing to its becoming increasingly removed from the growing organismal specialisation of food products, while secondly, for this same reason, its own food supply will become less and less suitable. This theory would apply equally to germinal and somatic development and atrophy of structure: there would thus, through the alteration of functional activity of the whole organism, be brought about elimination of all structures not in the line of evolution; and. therefore, organismal selection alone, if this theory is sound, would be able to explain the complete disappearance of rudiments, the various forms of development and atrophy, without calling to its aid climatic inheritance, panmixia, and germinal or any other form of particular selection."

12. See the account of the observations of Kellogg and Bell in the appendix of chap. iv.

${ }^{13}$ Morgan, C. Lloyd, “Animal Behaviour,” p. 269.

${ }^{14}$ De Vries, H., "Die Mutationstheorie," 2 vols., Igor, I903.

${ }^{15}$ Plate, in a later briefer treatment ("Darwinismus kontra Mutationstheorie," Archiv f. Rassen- und Gesellschaft-Biologie, Vol. III,

Plate's expla. Pp. I83-200, Ig06) of some of the offered objections to nation of charac- natural selection refers to this matter from a slightly ter fxity in do- different angle. "So sehr der Züchter danach streben mestic animals. muss, erblich konstante Formen zu erhalten. um der Mühe der beständigen Auslese enthoben zu sein, so wenig spielt dieser Punkt in der freien Natur eine Rolle. Hier findet eine nie nachlassende Zuchtwahl statt, wodurch der betreffende Charakter auf einer gewissen Höhe erhalten und vor Rückschlag bewahrt wird. Welcher Grad von Konstanz nun auf diesem Wege im Laufe von Tausenden von Generationen erzielt werden kann, ist eine zurzeit noch ungelöste Frage, die ihrer Natur nach wohl kaum mit Sicherheit beantwortet werden kann. Jedoch lehrt die Tier- und Pflanzenzucht, dass der Rückschlag nach dem Aufhören der Selektion um so später und um so seltener eintritt, je länger und je intensiver der Züchtungsprozess vorher betrieben worden ist. Daraus ist zu schliessen, dass die langandauernde Zuchtwahl, welche die Natur ausübt, jenen relativ hohen Grad von Erblichkeit zu erzeugen vermag, welcher den Spezies-Charakteren im allgemeinen zukommt, denn völlig konstant sind diese bekanntlich auch nicht."

${ }^{16}$ Tayler, J. L., "The Scope of Natural Selection," Nat. Science, Vol. XV, p. II9 ff., I899. 
DARWINISM DEFENDED (CONTINUED) : PLATE'S CONCILIATORY DEFENCE.

THE foregoing consideration of the answers of the Darwinians to the objections urged against the effectiveness of the selection theory as an explanation of evolution makes no pretence of having included, or even referred to, all the arguments offered by the defenders, and it is only fair to note that by no means all Darwinians and neo-Darwinians agree to making the concessions listed in the early part of the chapter. Some refuse a certain one or two of these concessions, some another or others, some indeed will make no admissions at all. With these last we are past arguing. The discussion assumes too much an "it is, it isn't" character to be particularly illuminating or progressive. But because of those who concede in considerable measure, and deny in some measure, the validity of those chief objections to the species-forming capacity of natural selection, the general character of the ground on which this last stand for the old flag is being made should at least be indicated.

This half-surrendered but still not quite deserted position is perhaps most clearly to be seen through the smoke of

Plate's con- battle by fixing one's eyes on the representative sideration of the figure of Ludwig Plate, a strong Darwinian,
objections to objections to

but one not blinded by prejudice or with ears wilfully closed to the calls of reason. In his recent elaborate discussion ${ }^{1}$ of Darwinism, so often already referred to and quoted from in these present chapters, he groups under the head of wesentlicle Einwände (important objections) the 
attacks on the species-forming capacity of natural selection, which are based on (I) the slightness and inutility of the fluctuating Darwinian variations, and (2) the improbability of the right variations appearing at the right time to make possible the developnent of specialisations of qualitative and coadaptive character. In a discussion of some length (pp. 32-77), mostly quite fair and unprejudiced, he brings out the best and strongest arguments that the faithful Darwinians have to offer to reduce the force of at least, if not to answer satisfactorily, even for themselves, the most effective attacks on the capacity of selection. In very condensed form I present in the following paragraphs the essential points in these defensive arguments.

In regard to the first objection, namely, that the very slight or small differences in organs and functions which result from the fluctuating or Darwinian varia-

The objection of Darwinian variations. to the sightness

tions cannot be sufficiently advantageous or disadvantageous enough to afford "handles" for natural selection, that is, cannot be of lifeand-death-determining value, Darwin devoted, in his "Origin of Species," a whole chapter of discussion and argument to show that in many cases even the slightest of differences may conceivably (it is of course a matter practically incapable of proof by observation or experiment) be sufficient to turn the scale, in a rigorous competition, one way or the other. In many other cases such differences could not, even to Darwin, appear sufficient to be of a life-and-death advantage or disadvantage. But Darwin too often, Plate admits, confounded mere usefulness ${ }^{2}$ with life-and-death-deciding usefulness (or non-usefulness).

However, for many cases Plate maintains that the slight Darwinian variations can serve as handles for selection, particularly in periods of unusual rigour of competition or fierceness of struggle (either active or passive): examples are, slight differences in the speed of preyed-on 
animals when pursued by an enemy, or slight differences in the length of neck of the giraffe in time of scarcity of foliage, or slight differences in the effectiveness of the organs of sense at times of approaching danger, or in endurance of cold, heat, hunger, dryness, etc., or in the clothing of hairs or feathers, the number of capillaries in the skin, or richness of glandular secretion, and the like, in times of special stress of weather. "DodelPort ${ }^{3}$ has shown that microscopically fine hairs are capable of keeping plant-lice away from leaves or buds, and that very slight differences in the specific gravity of the seeds of water-plants may determine whether these seeds sink to the bottom and consequently germinate or not. For the long flights of migratory birds or for birds like our house-doves which protect themselves from birds of prey by swift flights upward to great heights, every smallest amount of advantage in the pneumaticity of the bones will be of worth and finally of vital advantage, just as every racing bicyclist knows by experience that for his record-breaking attempts he must have a machine in which every part is made as light as possible, for the effects of weight are cumulative in course of time." And Plate fills a couple of pages with other similar cases. "Whoever scrutinises the life of nature and of man with biologically trained eye sees over and over again the coming of great effects from slight causes. The average of accidents in factories increases in proportion to the age of the workers, because muscular strength and keenness of the sense organs decrease with increasing age. In each age-class the difference is but slight, but in spite of that it demands its sacrifice. Nägeli, in a paper concerning the abundance of tuberculosis, showed that among 500 dead human bodies examined 97 per cent. showed traces, at least, of tuberculosis. That is, practically every adult human is tainted by this disease. Now how often must slight differences in body structure, life habits, 
hygienic conditions, yes, even in temperament, determine whether there shall be healing or death? The iridescent colours of many male birds, butterflies, and certain parasitic copepods (Sappharina), are certainly of a nature to produce a great effect on the eye, but these colour effects are not the result of special pigments but of microscopically minute structural conditions. In Africa the tsetse-fly ${ }^{4}$ extends over large regions, and only those cattle with a skin of a certain thickness, so that the tiny proboscis of the fly cannot penetrate it, can live in these regions immune from the fatal attacks of the pest. Many poisons work in almost infinitely weak dilution-a I-200,000 solution of ricin, for example, is able to kill mice."

Plate presents a second type of answer to the objection by calling on certain aids or auxiliary principles by whose in-

Correlation may aid slight variations,

fluence a difference at first unimportantly small gradually comes to be transformed into one of selective value, or may reach this stage suddenly by means of a change in life habits. This may come about "through correlation," that is, through that unknown law of growth by which an indifferent organ may be so bound up with or related to a useful organ ${ }^{8}$ that it, the indifferent organ, is perfected along with the useful organ as this latter is developed or specialised through selection. All organs of an animal are intimately related to and influenced by one another: each is in relation to the other just as to the outer world. How close this inter-dependence is, is most easily appreciated by one in his own case when sick: a constipation causes headache, a slight diarrhœa affects the composition of the urine, etc. The correlation can be so intimate and important, as the case of the secondary sexual characters shows, that its origin and development depends directly on particular definite stages of the related organs." In the case of many animals the appearance of various curious and large modifications of legs, wings, skin, feathers, 
hair, etc., etc., depends on the various stages of development reached by the reproductive organs. Now these secondary organs or modifications thus produced through the influence of other organs may be for a while slight and indifferent in character, but yet safely maintained. When they reach a stage of ntility or of positive disadvantage they will then be further perfected, or on the other hand be extinguished, by selection.

The principle of the change of function (Functionswechsel) first elaborated by Dohrn," is also called on by

Dohrn's prinPlate to play an important part in explaining ciple of change how an organ of considerable specialisation can of function.

be shown to have been developed by selection, although the function it is now performing seems to be one that could have been useful only in a perfected state and hence could not have made the organ so constantly advantageous in all the slow and gradual stages of its evolution as to be of selective value in its beginning stages. Dohrn's principle is stated as follows: "An organ can, in its service of a certain definite useful function, be developed by natural selection to a certain stage. Simultaneously a second function (Functionserweitcrung) can have developed, due to some special peculiarity or condition of the position, structure, or capacity for movement, which may have a value in another direction from that of the first function. Thus the appendages of crabs serve often special functions in relation to respiration, copulation, and care of the eggs or young, while their original locomotory function may still be maintained or may be more and more surrendered in favour of the new functions." Numerous other specific examples are obvious enough to any student of biology. Now the new functions in many cases become the more important so that there in time results a complete change of function which wholly alters the physiological character of the organ, and in many cases it is difficult to see (if one does. 
not know the phyletic history of the organ and the function) just how selection could have developed such an organ by slow degrees from slight beginnings. But the secret of the explanation, which is a perfectly consistent Darwinian explanation, lies in the Functionswechsel phenomenon.

"Indifferent characters can suddenly become of selective value through change of environmental conditions or of life-habits. The cranial sutures are certainly of no vital importance with the reptiles and birds, but they can be of very great importance to the viviparous mammals as adaptations for passing the pelvis during birth. Lacerta vivipara has, perhaps, no advantage through its viviparousness over its nearly related species in our country, but in Scandinavia it has to thank this peculiarity alone for its success in life, because the development of its young is rendered independent of the sun by it. The nectaries were probably at first useless to the flowers; from that moment, however, when the insects learned to know them as food reservoirs and unwittingly insured cross-pollination by their visits to. them, they became of the greatest importance and the indirect cause of the origin of the colour brilliance of the flowers.

"There are organs of universal character which can become modified in most widely differing directions. Thus the tail of the mammals, originally a long, erenly-haired organ, can, without going through any very elaborate changes, be modified into a bushy steering-rudder of special use in climbing from branch to branch; or by the outgrowth of a terminal tuft be changed into a flying fan ; or by the partial loss of the hair become a grasping organ, or a balancing organ, or an aid in leaping, a rudder in swimming, or a cover against rain and cold (Myrmecophaga jubata). The appendages of crabs, the cirri of the annelids, and the teeth of mammals are further examples of a similar plasticity and capacity 
for modification in the most manifold ways, in which the first stages are often of immediate use."

Following these suggestions as to the aid that selection may have from various helping conditions to make its starts, Plate discusses as further similarly help-

Plate claims aid from inherited results of ase, from orthogenesis and discontinuous variation,

ful conditions or auxiliary principles three most important matters, namely, the effects of continued use on parts, the principle of orthogenesis, and the facts of sudden discontinuous variation. But as these three categories of biological phenomena and principles are exactly those, among others, which anti-Darwinians hold to be not aids to the selection theories, but to be the basis if not of actually replacing or substitutionary theories, at least of precisely those objections to the species-forming capacity of the strict Darwinian factors which have necessitated some of the principal concessions made by the Darwinists, it is obvious that Plate's discussion of them is in itself simply the actual making of the concessions already noted as having been admitted by most Darwinians. Each of these categories of phenomena and principles is of course of much importance and interest, and they will all be found to be fairly fully set out in the chapters following this one.

Plate's answers to the second important objection, namely, that selection relies too much on chance and is therefore

Answers to the objection concerning the dependence of selection on chance. improbable and inexact, may now be noted. He distinguishes two phases of this objection. The first he expresses as follows: "It is highly improbable that for the progressive development or perfecting of an organ there will always appear just at the needed time the variation necessary for selection, that is, the exactly needed adaptive modification." The second phase is: "It is highly improbable that in the development of a complicated organ, or body-part, or in the perfecting of a changing adaptation the numerous indis- 
pensable modifications will appear in such a series that a harmonious correlation of the single variations will be possible."

Referring especially to the first phase of the general objection he says :

"Thus this doubting query is, why do there always appear just the right variations at the right time? Or, somewhat differently expressed, in the words of Cope," 'since the number of variations possible to the organism is very great, the probability of the admirably adaptive structures which characterise the latter having arisen by chance is extremely small.'

"Whoever expresses such doubts unwittingly hitches the wagon before the horse. Selection directs itself according

Selection follows variation, not variation selection. to the variation, not variation according to selection. If the variability is large, selection has a large choice; if the variability is small, then there are but few lines of evolution open. Experience teaches that in general, the variability of organisms is very large, that it occurs both quantitatively and qualitatively in such pronounced manner in all individuals of a species that it can be readily recognised without recourse to complex methods of investigation, and that no characteristic (size, form, colour, numerical relation, constitutional vigour, instinct, life-habit) is free from it in any life stage from egg to last drawing of the breath. It is precisely to this variability expressing itself in the most manifold ways and combinations that is to be ascribed the condition that any individual as such is, usually, readily to be distinguished from other individuals of the same species. It results from this that the individual variation is indeterminate and undirected, or better expressed, universal and all sided, and that at any given moment the exactly needed modification will always appear in a number of individuals of any species rich in individuals, provided that 
the needed variation can be produced through a slight advance or progressive change. Naturally it is not sufficient if the variation appears in only a few isolated individuals, but it is necessary, for the modification of the species, that this variation occur in so many individuals that it will not be extinguished through interbreeding but on the contrary will be perpetuated. In other words selection works, except Selection works in scattered cases where single or rare variawith plural vari- tions are specially favoured by accidental isoations.

lation, not with single but with plural variations or varieties. Through this the host of variations is immensely reduced as far as they come into consideration as handles for selection, and of course only in this sense is there any reason at all for the query as to whether we can assume that the right variation will always be present at the right time. The answer can only be, certainly not always: many promising beginnings must always be checked in the germ or at half-way, but in infnitely many cases the needed plural variation will appear, because the same external factors change a whole group of animals simultaneously so that progress is possible. But, it goes without saying, only a slow advance is conceivable on this basis.

"One must not, for the rest, forget that the same condition of selective worth may be reached simultaneously

Same selective value may be attained in different ways. through combinations of different peculiarities, and that the same effect may be attained by various means, both of which facts render it importantly easier to get this selective worth. When pursued by an enemy one individual of the harassed species may save itself by a quick leap, a second through sharp ears, a third by sharp eyes. Wallace rightly explains. that the necessity for a giraffe in times of famine is only to reach as high as possible in the trees, and that different means may avail for this, as a longer neck, long legs, or a long tongue, all of which may eventually come to be corre!- 
atively increased. The individuals which survive by these aids may then later, through inter-crossing, exchange their advantages and so lead to the production of a mean type that shows a slight advance over earlier conditions in all three organs. Nammals can protect themselves from flies in various ways, either by a thick fur (bears), by reflexive twitchings of the skin muscles (horse), by tails with tufted ends (many hoofed animals), by a long neck which can bend sideways so that the animal can reach any part of its body as far as the hips (guanaco, stag) or finally by eyelids and long movable ears, which restrain the flies from the easily injured eyes. These means of protection from insects play an important rôle in determining the habitus of many mammals, and permit the conclusion that selection has been instrumental in producing this habitus. Here, also, it is possible for several of these means to be possessed at once by the same animal, as in the case of the guanaco with its long hair and elongate neck. It is absolutely necessary for molluscs that live between tide-lines to have some means of resisting the force of the surf. Many species possess this means in their small size which allows them to crawl into crevices and cracks in the rocks, but most of them have developed a strong pedal sucker and a low roof-like uncoiled shell which presses close to the rock surface and over which the water flows without exerting any strong lateral pressure. This is the case, for example, with Patella, Fissurella, Chiton, Concholepas, Siphonaria, Gadinia, Calyptra, and others. All three of these means of safety can come into play simultaneously in selection, but it suffices when any given individual possesses any one of these means in sufficient degree of development.

"I shall note here several other examples which show how related species reach the same advantage in the struggle through different means, for we can assume from these facts that also the individuals of the same species often 
escape the same dangers in the struggle for existence by means of different means. And by this the probability is made greater that the 'needed variation' appears at the right time. The differing characteristics of this sort will later lead, through crossing, to the formation of a mixed type, or, if the competition grows ever sharper with the course of time, they will produce a separation of the species into varieties (eventually species) with differing habits of life, or finally they may meet in direct competition or struggle with one another. The good flyers among the birds all have long wings, but in some it is the fore arm which is specially lengthened (cuckoo, goat-sucker, pigeon), in others the hand (terns, humming-birds, eave swallows), and in still others the upper arm (swan).-While Tapirus americanus, like most mammals, drives the flies away from its eyes by throwing down the eyelids, Tapirus indicus accomplishes the same thing by a strong rotation of the bulb of the eye. Elephas africanus seizes very small objects with its proboscis-fingers, while the Indian elephant lays the front end of the trunk laterally on the ground, grasps the object between the skin-folds, lifts it up high in this way, and only then allows it to fall into the tip of the proboscis.Poulton has shown by several examples that in cases of mimicry the same effects may be got in very different ways. The glass-like transparency of the wings, for example, is got in the Heliconid genus Menthona by a considerable diminution in size of the scales, in the Danaid Ituna iliona through the absence of most of the scales, in Castnia linus var. heliconoides, through the absence of pigment in the scales, which are as large and numerous as usual, in the Pierid Dismorphia crise through the smallness of the scales, and finally in the night moth Hyelosia heliconoides by the absence of pigment and lessened number of the scales."

Plate next offers a detailed explanation on strict Darwinian grounds of how such an extraordinary condition of 
mimicry can be brought about as the famous case of Kallima, the butterfly that simulates in colour, shape, and intimate details of pattern such as veins, flecks, The case of fungus spots, etc., a dead leaf with such fidelity Kallima,

as to make it the wonder of every one who sees it and the classic example of the possibilities of such protective resemblance. And he shows well that whatever difficulties selection may have in its necessary dependence on the chance occurrence of the proper numerous and necessarily simultaneously appearing variations to explain the gradual development of such a specialisation, the only other explanations so far offered are even more ludicrously dependent on "luck." Piepers," the most active and polemically vigorous of all special opponents of the Darwinian explanation of protective resemblance and mimicry, says: "Chance alone can bring about such a correlation." As Plate well says, "It is not without its comic aspect that a violent antagonist of the selection theory should be found clinging to the same safety-anchor 'chance,' that usually is the constant reproach of the Darwinian. . . . It would not be difficult," continues Plate, "to refer to still other examples. to show that a needed selective value can often be attained at the same time by the individuals of a species through various means, by which the probability that this type of adaptations can arise is correspondingly increased. But one point should never be forgotten and that is it is always first the variability, and second the selection. If no variations appear there can be no progress, and if the struggle for existence were too severe the [non-varying] species would die out. Strictly speaking, the question, how is it possible that the right variations can be relied on to appear at the right time? is really inverted and therefore incapable of receiving a correct answer. One can only say: If a complex adaptation has arisen through selection, then it is certain that the necessary modifications. 
needed for success in the struggle for existence were not wanting."

We come now to the second phase of the general objection, as analysed by Plate; viz., the assumed improbability that during the course of the development Answer to the (evolution) of a complicated organ or whole claimed improbability of the timely appearance of variations needed in co-adaptive structures.

body-part, or during the perfecting of a changing adaptation, the numerous necessary variations will occur in such a successive series as to make possible an harmonious correlation of the various single variations. Plate writes as follows: "This objection has been, as is the case with the objection just discussed, raised by many students of evolution as Spencer, Wigand, Nägeli, and is in principle not different from the previous objection, but only presents an elaboration of it. It concerns, first, the numerous single variations which are necessary if a single complex organ (as an eye) or a whole body-part with its various organs and tissues (for example, the neck of the giraffe, the fore body of the elk) of a single individual is to be raised to a higher stage of adaptiveness; and, second, the perfecting of interdependent adaptations in different individuals. As example of the latter category I may mention the corolla of flowers and the proboscis of insects which cross-pollinate these flowers, the male and female copulating organs of many animals, as those of the Papilionidre, the adaptations of myrmecophilous and termitophilous animals in relation to their hosts, also those of symbiotic (parasitic or mutualistic) species relative to their companions, and, in cases of mimicry, of the mimicking species relative to the protected species. When one of the species, party to such a mutual adaptation, changes, the other as a rule must also. There arises from this the query : how, in sucl cases, is there possible the necessary coadaptation (coördination), that is, the harmonious change of the parts which produce the interdependent physi- 
ological or biological phenomena, whether these exist in a single individual or in two? How does it come that when the antlers of the giant stag become larger and larger, the skull bones become thicker and the neck tendons and the fore legs stronger (Spencer)? With the gradual lengthening of the giraffe's neck the skeletal system and with it numerous other closely-related internal organs have to become larger simultaneously. Hundreds of small modifications are necessary. How does it happen that all come off exactly as is necessary? When the flowers' cups for any reason become deeper the insects must develop longer proboscides in order to reach the nectaries in the bottom of the cup. Simultaneously the sucking apparatus of the œsophagus must change. How does it happen that these modifications in two different organisms, in an animal and a plant, occur pari passu?

"In order to satisfy these questions of doubt Darwin and Wallace have referred to the domesticated animals as the best proofs that such coadaptations are possible. A greyhound, a bulldog, a dachshund, a tumbler pigeon, a racehorse, have had to pass through a long series of numerous changes in the most various organs, in order to reach their present form, and yet all these variations have appeared one after the other in such a way as never to endanger the vital vigour, for man would never have chosen weakly animals for breeding purposes. In artificial selection, therefore, coadaptations are possible in almost infinite variety, and it can fairly be asked if such favourable conditions are not also possible in nature. This query must, a priori, be answered in the affirmative, for man is not able either to make more easy or to hasten the appearance of coadaptations: he can only hold on to those which once appear, and this can also be done by the struggle for existence in those cases in which the coadaptive variations are of vital importance. The real difference lies, therefore, in the fact that 
man can make a beginning with ever so slight an advance; nature only with such simultaneous changes as are of suffcient grade or degree to be of selective value. And so far in this discussion nothing has been offered to show how this condition is to be reached."

To attempt to get at an explanation of the actual means by which this necessary condition is attained, Plate believes it Plate's belief necessary that one should make clear just what in the possibility standpoint he takes on the vexed problem of tance of acquired the inheritance of acquired characters. Witheharacters, out going into Plate's long discussion of this old subject, it is sufficient to say that he reaches the conclusion that the inheritance of acquired characters is not proved not to be possible, and hence that it may occur. And, for himself, he expresses the belief that acquired somatic characters can be and are inherited. From this point of view, he, consistently with Darwin's own position, finds an answer to the objection touching the necessity of a repetitive cumulating appearance of certain definite kinds of variation for the basis of the development of coadaptation, by invoking the Lamarckian factor of the inheritance of the effects of use and functional stimuli. Which refuge is of course not open to the modern strict selectionists, the neo-Darwinians.

Now, as may be imagined, when the Darwinians themselves are of various minds about the value of the answers to this objection, when these answers are based on a strict selection basis, they are not very convincing to anti-Darwinians. In general they rest on various observed facts and deduced assumptions which may be roughly classified into several groups. First, the facts of simultaneous correlative variation, or the fact that organs or parts which function together, very often vary in the same general direction. For example, if two leg or arm bones become longer the muscles attaching to these bones also become longer (since the attachments are not changed). The supplying blood-vessels 
and nerves also lengthen. Numerous observations by breeders show that in each organism there resides a capacity of self-regulation, up to a certain degree, which produces a harmonious growth and variation of inter-dependent parts. If a plant is removed to richly fertilised soil it will grow to great size, in the course of which growth all parts are proportionally changed so that the general habitus of the plant remains the same. If one allows insect larvæ to live on very short food rations, the adult insects will be unusually small but with all the organs of their usual relation to each other as to proportional size. Thus it seems that the single organs are definitely correlated with one another so that in their growth they maintain their relative characteristics. "I have," says Plate, "called this form of organic Zweckmässigkcit the unity of organisation." If this quality or capacity is lacking in an individual then it develops into a cripple, a monster, and is killed out by selection. Therefore, if the neck of the giraffe varies so as to be longer, one may fairly assume that, in the case of many individuals, at least, all parts of the neck will share in this variation, although there will naturally be slight individual varyings inside of this general variation. And if the antlers of the stag vary towards a larger size there will simultaneously appear the necessary increase in calcareous materials for all parts of the skull, so that the whole skull will be correspondingly heavier and stronger.

"The process of evolution may be assumed to be, as it was by Darwin, very slow, so that plenty of time is allowed to selection to produce the necessary coadaptations which may be wanting in the earlier stages of the development. In the case of the enlarging of the stag's antlers there may have been wanting at first the necessary congenital strengthening of the neck muscles but this would come to exist through use. The effects of use would increase, however, only to a certain point, and there would finally come a time when the 
heavy antlers could be supported only by those individuals which had received a strengthening of the neck muscles through congenital variation. All others would be killed out.

"The already discussed principle of the attainment of selective value for a certain advantage by various means, comes also into play in this connection. In time of drouth it is important to the giraffe only that it can reach a certain height on the trees; whether this height be reached by the aid of a longer neck or higher shoulders or a specially elongate tongue is indifferent. Through inter-breeding these various advantages may be later united. There is always resulting, as Wallace " has said, "Selection of the capacities or qualities resulting from the infinitely varied combination of variations that are always occurring.'

"Recently Weismann" has presented the principle of germinal selection as explaining coadaptive specialisations,

Plate's disbelief in Weismann's principlo of germinal selection. so that he is evidently not satisfied with the sufficiency of the three aiding explanations already given. I hold this germinal selection," says Plate, "to be a false conception, and therefore do not here refer to it further. It will be discussed in detail later." (This later discussion of Plate's is a detailed and effective destructive criticism of the theory.)

"Weismann, in his 'Lectures on the Theory of Descent," 12 outlines in detail his theory, proposed several years before,

Weismann's principle of amphimixis. that amphimixis (bisexual parentage) is so widely prevalent in both the plant and animal kingdoms, because it serves as the spring of individual variations. A considerable part of the chromosomes of the egg-cell is removed by the discharge of the polar bodies, and the same results from the reduction divisions of the sperm-cells. By this the possibility is created of producing, through the fusion of the germ-cells, very various combinations of the hereditary tendencies and, therefore, an actual high degree of variability in the offspring. 
'Because in each reducing division of the germ-cells their ids are lessened by one-half, the possibility exists of gradually removing from the germ-plasm of the species the ids of the disadvantageous variations, for in each generation the offspring of the disadvantageous id combinations are extinguished [by selection], so that from generation to generation the germ-plasm gradually becomes purified of the disadvantageous ids, while the favourable combinations which amphimixis produces are retained, and there finally remain only the advantageously varying combinations or, at any rate, those in which the advantageously varying determinants are in the majority and therefore inave the most influence' (Vol. II, p. 222). This conception of the significance of the reduction divisions of the maturing germcells and their fusion is very suggestive, and, theoretically, there is little to be objected to in the idea that the differences thus created can be used by personal selection for the production of harmonious coadaptations. Indeed, with this explanation in hand, it is obvious that the theory of germinal selection is superfluous for the explanation of coadaptations if we may assume that there is always a great mass of material in the individual variations, for the possibility of varying combinations of these requires no further explanation."

For the most part it is obvious that Plate, and with him other fair-minded Darwinians, recognise fully the Plate recog- cogency of the objections against Darwinism nises the weight based on the inutility of slight variations, on of certain objec-
tions to Darwin- the occurrence and persistence of hosts of ism. trivial or indifferent species differences, and on the difficulties presented by the demands of a controlled appearance of variations necessary to the development of coadaptive structures and functions, so that they are inclined to make the concessions which I have referred to in the beginning (chapter vi) of this presentation of "Darwinism 
Defended." With these, concessions made it is necessary to call to the aid of the selection theory, if it is still to be considered an important factor in species-forming-these concessions do not, of course, invalidate the claims of selection to be the all-important final factor in determining the general course of evolution, by encouraging or restraining the various general lines of descent-certain auxiliary and aiding theories or explanations. Such helps to selection are to be found especially in isolation, organic selection, and the Weismannian theories of panmixia and germinal selection. The outlining of these theories will form the contents of our next chapter.

\section{APPENDIX.}

${ }^{1}$ Plate, Ludwig, "Über die Bedeutung der Darwin'schen Selectionsprinzip," I903.

"The question, what is meant by "selective value," has been discussed by Conn ("Method of Evolution," pp. 83-86, I900), as folConn's discus. lows: "How useful must a character be to be of sion of selective selective value? Such a question it is, of course, imvalue. possible to answer. The preservation of any particular character is not an isolated matter. It is not single characters that are preserved, but a combination of many characters together. The survivor is the animal showing the best combination of characters. It may even have some harmful ones, provided the useful ones predominate. The rattle of the rattlesnake has at times doubtless been of a disadvantage to its possessor, and has caused the death of hundreds of thousands of individuals. It is doubtless possible to show, as Darwin did, that it has also been of value to the animals. But how are we to decide whether its use or disadvantage is the greater, except by the theoretical conclusion that it must on the whole be useful or it would have been eliminated? The whole study of utility is sure to result in an unsatisfactory circular logic, something as follows: The survival of the fittest is a law. If an organ be not useful it could not have been developed by natural selection. Therefore, all organs and all characters must be useful. Since in such a problem no one can prove a negative, this position cannot be disproved; but it is certainly not very satisfactory. 
"But with all this criticism of utility it must be recognised that the agency of utility as determining survival is becoming more significant as discussion proceeds. We have seen that it must be admitted that all characters to be affected by the principle of survival, must have selective value: $i$. e., must affect the matter of life and death. But this demand does not prove to be so serious when we recognise that natural selection works upon general averages rather than individuals. Those who find the selection principle such a great factor insist that all characters have selective value if they have any value at all. If a character has the value of even rendering its possessor a little more comfortable, they tell us it will eventually be subject to the principle of survival at the expense of non-favoured animals. The substitution of old types by new ones is not a matter of a single generation. but many generations. In such a long history there must be innumerable conditions where any character, even the slightest, may have been of use enough to give its possessors an advantage over others. It is not necessary to believe that a character should preserve its possessor, while all non-favoured individuals perish, in order to consider that the character has selective value. Considering that the origin of species is a matter extending over hundreds of years and many generations, even little things will count in the long run. If an animal has a slight advantage over another, which simply gives it more comfort and enables it to obtain its food with a little less exertion, this may tell permanently in the struggle, since such an individual will have more energy to put into reproduction, and hence may leave a larger number of offspring. The other nonfavoured individuals may not, indeed, be exterminated without offspring, but may simply produce less offspring. In this struggle for permanency, the individuals which have the largest number of offspring, other things being equal, will inevitably come out ahead, and the others in time disappear.

"An example will make this clearer. A difference of an inch or two in the length of a cow's tail seems a matter decidedly too small to base the selection principle upon. Can it be imagined that the lengthening of the tail by a couple of inches can be of selective value? Can we honestly believe that these two inches will determine that the longer-tailed cow will live and produce offspring, while the shorter-tailed individuals will die? Only thus, however, can we assume that the tail has been developed by natural selection. Now this example, which seems to be an extreme case of slight utility, may show us how it is possible, upon the principle of the selection of averages, to conceive that characters of slight use may be preserved by natural selection. It is not necessary to 
suppose that the long-tailed individuals are preserved by this extra couple of inches at the expense of the shorter-tailed individuals in order that the character may be within the reach of natural selection. If the animals are troubled by insect pests, it is certainly a matter of convenience to them to have a tail long enough to brush off the flies, and the longer tail, within certain limits, will be more useful than a shorter one. It is not likely that this will preserve the life of a single individual, but it will follow that the animals with longer tails will be less irritated by insects than those with shorter tails. Now, although this would not affect the matter of life and death, a nervous irritation would pretty surely interfere with the reproductive efficiency. An animal that is constantly bothered by insects will have less nervous energy to devote to reproduction, and, therefore, such a constantly irritated animal would be likely to be somewhat less prolific than one less irritated. From this it would follow that the half of the animals with tails a little longer than the average, would be pretty sure to leave a somewhat larger number of offspring than the half whose tails were below the average. But a slightly increased fertility of this sort would, in the course of a few generations, see the long-tailed animals: becoming more and more numerous, until they would eventually replace the others."

${ }^{3}$ Dodel-Port, A., "Wesen und Begründung der Abstammungsund Zuchtwahl-Theorie in zwei gemeinverständlichen Vorträgen," 1877 .

"The tsetse-fly (Glossina sp.), long notorious as a terrible pest of cattle in Africa, produces its ravages by disseminating (through biting, $i . \quad \mathcal{c}$., puncturing the skin) the specific causes (certain minute blood-inhabiting parasitic one-celled animals known as trypanosomes) of the plague called Nagana (fly disease).

${ }^{5}$ For an elaborate discussion of the principle of correlation (not bearing perhaps except in a general way on the point just at issue.

References to but of much general interest) see Radl, Em., "Über papers on corre- die Bedeutung des Prinzips von der Korrelation in lation. der Biologie," Biol. Contralbl., Vol. XXI, pp. 40I4I6, 490-496, 550-560, 605-621, I901. See also Webber, H. J., "Correlation of Characters in Plant-Breeding," Proc. Amer. Brecders" Assoc., Vol. II, pp. 73-83, 1906.

${ }^{6}$ For examples see R. Meldola, "The Utility of Specific Characters and Physiological Correlation," Proc. Ent. Soc., London, pp. 62-92, I896; also A. R. Wallace, "The Problem of Utility; are specific characters always or generally useful?" Jour. Linn. Soc., Vol. XXV, pp. 48I-496, I894. 
${ }^{7}$ Dohrn. Anton, "Der Ursprung der Wirbeltiere und das Princip des Functionswechsel." I875.

${ }^{8}$ Cope, E. D., "The Energy of Evolution," Amer. Nat., Vol. XXVIII, p. 205. I894. I quote the following: "In considering the

Cope's proof that natural selection cannot make new characters. dynamics of organic evolution, it will be convenient to commence by considering the claims of natural selection to include the energy which underlies the process. That natural selection cannot be the cause of the origin of new characters, or variation, was asserted by Darwin,* and this opinion is supported by the following weighty considerations.

"(I) A selection cannot be the cause of those alternatives from which it selects. The alternatives must be presented before the selection can commence.

"(2) Since the number of variations possible to organisms is very great, the probability of the admirably adaptive structures which characterise the latter having arisen by chance is extremely small.

"(3) In order that a variation of structure shall survive, it is necessary that it shall appear simultaneously in two individuals of opposite sex. But if the chance of its appearing in one individual is very small, the chance of its appearing in two individuals is very much smaller. But even this concurrence of chances would not be sufficient to secure its survival, since it would be immediately bred out by the immensely preponderant number of individuals which should not possess the variation.

"(4) Finally, the characters which define the organic types, so far as they are disclosed by palæontology, have commenced as minute buds or rudiments, of no value whatsoever in the struggle for existence. Natural selection can only effect the survival of characters when they have attained some functional value.

"In order to secure the survival of a new character, that is, of a new type of organism. it is necessary that the variation should appear in a large number of individuals coincidentally and successively. It is exceedingly probable that that is what has occurred in past geologic ages. We are thus led to look for a cause which affects equally many individuals at the same time, and continuously. Such causes are found in the changing physical conditions that have succeeded each other in the past history of our planet, and the changes of organic function necessarily produced thereby."

'Piepers, M. C., "Thesen über Mimikry," Verh. Internat. Zool. Cong., p. 350, 1902.

* "Origin of Species," ed. I872, p. 65. 
${ }^{10}$ Wallace, A. R., "Are Individually Acquired Characters Inherited ?” Fortuightly Review, Vol. LIII, pp. 490-498, I893.

${ }^{11}$ Weismann, A., "Über Germinal-Selection," Verh. Internat. Zool. Cong., i 896.

12 Weismann, A., "Vorträge über Descendenztheorie," 2 vols., I902. 


\section{CHAPTER VIII.}

\section{OTHER THEORIES OF SPECIES-FORMING AND}

DESCENT: THEORIES AUXILIARY TO SELECTION.

To be considered now are two categories of (mostly) post-Darwinian theories, viz., those which have been offered

Classification of other theories as anxiliary or alternative to selection.

as alternative theories intended to replace more or less nearly entirely the selection theories, and those other theories intended to serve as auxiliary and supporting theories for Darwinism. Obviously these two kinds of theories ${ }^{2}$ emanate from the two opposing biological camps. Several of these alternative and auxiliary theories of species-forming have been referred to incidentally in the preceding two chapters, for the replacing theories constitute part of the strength of the anti-Darwinians, while the supporting theories are distinctly relied on to help maintain the Darwinian front. The present chapter, then, is mostly a continuation of the presentation of "Darwinism Attacked" and "Darwinism Defended," which is given a separate place because of the special character of the argument with which it has directly to do, namely, the synthetic or theory-building side, instead of the analytic or theory-destroying side, and because of the probable advantage to the student and general reader wishing to understand and compare the general character and significance of the various new theories of speciesforming with whose names, such as heterogenesis, orthogenesis, metakinesis, geographic isolation, biologic isolation, organic selection, or orthoplasy, he occasionally meets in his 
general reading. As directly continuing the last chapter we may consider first those theories put forward, chiefly by Darwinians, as auxiliaries or supports of the selection theory. Then we may briefly take up those theories that have been advanced, mostly in recent years, as more or less nearly completely prepared to replace Darwinism as a sufficient scientific causo-mechanical explanation of speciesforming and descent.

The Weismannian Theories of Panmixia and Germinal Sclection. ${ }^{2}$ - Weismann has for years been the most conWeismann'sim- spictious of the neo-Darwinians, that is, of Weismann's im-
portnt contribu- those who would free Darwinism from all taint tions to biology, of Lamarckism-it should always be remembered that Darwin was inclined to attribute some degree of influence in species-forming to the Lamarckian factor of the inheritance of indiviclually acquired adaptive characters-and to make selection the all-sufficient and, indeed, sole factor in species-forming. His great services to biology in general and to the clearer understanding of the problems of heredity and descent in particular, are unquestioned and unquestionable. His careful investigation and illumination of the vexed question of the inheritance of acquired characters, his definitive exposition of that point of view which distinguishes sharply in the individual between the germplasm (that particular protoplasm in the body from which the germ-cells, eventually new individuals, arise) and the soma-plasm (that which develops into, or gives rise to, the rest of the body), his development of the interesting and suggestive combinations of fact and theory designated by the phrase names "continuity of the germ-plasm" and "immortality of the Infusoria,"-these products of his investigating and philosophising mind prove him one of the ablest of modern biological scholars. They also make him the principal present-day champion of the selection theory. For all these expositions of fact and theory are of a nature to. 
enhance the credit of selection and to discredit certain other species-forming theories, in particular the only one, namely,

Weismann as champion of selection.
Lamarckism, which, until recently, has been in any real sense a rival of Darwinism. Against Weismann then and against Weismann's remodelled kind of Darwinism, against his propaganda of the Allmacht of selection, the adherents of Lamarckism and the critics of selection have turned their sharpest weapons. The result of the struggle has been to compel Weismann himself to say: "Although the principle of selection appears to solve in simplest manner the riddle of the fitness (Zrueckmässigkeit) of all arising organisms (alles Entstehenden), yet it appears ever more clearly in the course of the further investigation of the problem, that one cannot explain all with it, at least in its original limitations (dass man mit ihm, in sciner ursprïngliche Beschränkung, wenigstens, nicht ausreicht)."

To support the selection theory in two of its weakest and most criticised places, Weismann has proposed two striking auxiliary theories, namely, the Theory of Panmixia, to explain the degeneration of functions and organs, and the more recent Theory of Germinal Selection, to account for the now practically generally admitted existence of orthogenesis or determinate variation and evolutionary progress along fixed lines even to the possible final disadvantage of the organisms involved, and to account for the beginnings of variation and their maintenance until sufficiently developed to serve as handles for selection. The proposal by Weismann of the second theory, that of germinal selection, was the practical admission on his part of the impotence of selection to initiate new lines of development or descent. It was a concession on Weismann's part of the justness of the demand for an evolutionary factor to explain the beginnings of lines of development, whether of new organs or new species. And there is no doubt that it is 
the most ingenious mechanical explanation yet offered of the workings of such a factor. Indeed, Weismann, with characteristic ingenuity and capacity, has offered the believers in orthogenesis that which they so far had not been able to get for themselves, namely, a possible causo-mechanical explanation of it. It should be noted that Roux's theory of the battle of the parts (explained later) was a forerunner of, and undoubtedly the suggestion for, the theory of germinal selection.

Familiar to all students of biology, and certainly not wholly unfamiliar to laymen, are those structures or parts

The theory of panmixia to explain vestigial structures. in the body known variously as vestigial structures, rudimentary or degenerate organs. The vermiform appendix in man is one; the eye of the mole is another; the functionless wing of the ostrich, the useless fore-feet of a milk-weed butterfly, and the splint bones of the horse, are others. Almost every animal kind possesses vestigial organs, and some kinds possess very many. Those in the human body make an amazingly long list. All these are organs, which have oncethat is, in ancestors of the present particular organism -been well-developed and probably useful. But these organs now are unseless or even harmful. The human appendix vermiformis is harmful; the tiny fore-feet of the milk-weed butterfly are useless. Why do animals have such vestigial organs? Because they derive them by heredity from ancestors. But in these ancestors the organs were well developed and useful. How is it that the present organisms do not need the same organs? They have adopted new habits, or live in a new environment, or have developed other means of supplying the old want; in a word the organs are superfluous. How is it that the organs have become thus degenerate or vestigial? This is the question that selection has difficulty in answering satisfactorily. Selection can develop and specialise organs of use and advantage; 
but how can it cause organs no longer useful and advantageous to degenerate?

It is possible, perhaps, to explain the eradication of positively harmful organs by a process of negative or reversed selection. If an organ becomes actually harmful because of a change in life conditions, individuals with the organ in poorest, least energetically functioning condition might be conceived to have an advantage and be preserved by selection to pass on to their offspring this less developed, i. e., rudimentary or vestigial, character of the particular organ in question. But when the organ is simply only rendered useless by the change in life conditions, as when a species of fish or insect gradually comes to inhabit deep dark caves and thus has no more use for its eyes, how does selection explain the degeneration? It really doesn't, satisfactorily. So Weismann offers the theory of panmixia to account for it. This is, simply, that owing to the cessation of selection in regard to the particular organ whose function is rendered no longer advantageous or necessary under the new life conditions-that this cessation of selection is an obvious result of such a state of affairs was recognised by Darwin himself, and by other biologistsindividuals born with this organ defective or in a condition below the average. would not be necessarily killed by the rigours of the intra-specific struggle, and would therefore be as likely to mate and keep on producing offspring as the ones with the organ in average or above average conditions. This general participation of all kinds of individuals (all kinds, that is, as regards the state of the particular organ) in producing the next generation, and the continued repetition of this general mixing, panmixia, would obviously lead to a reduction of the earlier high condition of development of the organ. Weismann thinks, or thought, it would lead to a steady degeneration of the organ. But few other biologists, even those ardent selectionists anxious to find in 
panmixia an explanation not involving the admission of any new organ-modifying factor, have been able to see how panmixia can do more than simply reduce the organ to a certain stage below the original state of greatest effectiveness. By resorting to mathematics several writers have determined the exact-unfortunately for their convincing character-sezeral degrees of reduction or degeneration that will result from panmixia. The difficulty of explaining degeneration (to the degree in which it is manifest in thousands of known cases) on the basis of panmixia alone, is that there is included no factor or influence that would sum up or cumulate variations in a retrogressive direction any more than in any other. The Darwinian variations of the useless organ wotld, by the law of error, simply keep the organ, thus abandoned by selection, swinging about a mean but little below the condition possessed by the organ at the time of its abandonment. If the organ were large enough, or of a character whereby it would entail a constant considerable disadvantageous expense of food material to maintain it, then selection might, on a basis of an advantageous economy of living, tend to reduce it to a non-disadvantageous size or character. But this disadvantage, although easily presumed by carrying out the rigour of the struggle to a logical extreme, cannot, in fact.-and biologists on the whole admit this,-in common sense be assumed.

Lamarckism offers a perfectly simple and perfectly effective and satisfactory explanation of vestigial organs and the

The Lamarckian explanation of vestigial structures. modus of their degeneration. But to accept this means to accept the basic principle of Lamarckism, namely, the inheritance of acquired characters. And it is one of Weismann's most conspicuous positive achievements that he has demonstrated the unproved character of this theory. Lamarckism says that the first fishes to go into the dark cave suffered a partial individual degeneration of their eyes through disuse and 
that this eye degeneration was inherited by their young, whose eyes, already bad, suffered further degeneration in their life-time through disuse, and that after comparatively few generations this cumulative actual morphologic degeneration through disuse-and we know that unused active organs, as muscles, stimulus-perceiving parts, etc., do actually degenerate in an individual's life-time through disusewould reduce the eyes to a very degenerate condition. Other cases of degeneration, especially of passive organs ( $i$. e., where the organ's condition was not so wholly a function of use or disuse, but of the direct moulding influence of extrinsic influences), are explained by Lamarckism on the basis of the inheritance of the results of the direct action or influence of environment on the organ. . For example, the gradual disappearance of pigment (blanching) characteristic of many cave animals, would be explained by the absence of the extrinsic factor, light, which is necessary to stimulate pigment production.

In necessarily closing this all too brief reference ${ }^{3}$ to panmixia, it may be said that WVeismann himself has in recent years recognised its unconvincing character; and that Plate, a strong upholder of selection, in a most careful weighing of panmixia, finds it capable of explaining functional degeneration but not any actual considerable morphological rudimentation.

The Theory of Germinal Selection was proposed by Weismann in I895, more definitively in I896. Plate introduces

Weismann's his discussion of this theory as follows: "Its theory of ger- aim is the rehabilitation of the selection princiminal selection, ple. It shall overcome all objections and doubts which have been raised against the selection theory and shall act as the magician's wand to clear all difficulties from its way. Its strength shall avail in four directions. First, it shall explain how not only degeneration (physiological) but rudimentation (morphological) occurs in panmixia; second, 
why exactly those variations needed for the development of a certain adaptation appear at the right time; third, how correlation of adaptation comes to exist; and fourth, how variations are able to develop orthogenetically along a definite line, without depending on the necessity of a personal selection raising them step by step." Weismann himself refers to the theory as "a spring of definitively determined variation." In I902, Weismann further applied the theory to the explanation of monsters, and other cases of teratogenesis, of "sports" (sudden or large discontinuous variations), of suddenly appearing sex-characters, of specific talents, and still other heretofore unsatisfactorily explained phenomena.

In defining the theory of germinal selection we come at the very start to a difficulty based on the fact that little or

The physical and chemical structare of protoplasm. no reference has heretofore been made in this book to certain various theories or speculations as to the ultimate structure of protoplasm, especially the protoplasm of the germ-cells. In recognising protoplasm as the "physical basis of life" (Huxley's phrase), biologists have naturally tried to find in its actual physical make-up some clue to its marvellous capacities. The highest powers of our best microscopes, however, reveal little more of this intimate physical structure than does our unaided eye. Probably the colloidal character of protoplasm, that is, its amorphous, non-crystalline, viscous condition, is the most important physical fact about it revealed by our closest examination. But this apparent simplicity of physical structure is very unsatisfying to most biologists, and they demand the assumption of an extremely complex structure; a subdivision of germinal protoplasm into structural units and groups of units, just as the chemist assumes, in his atomic theory, a subdivision of substances into molecules and atoms. These protoplasmic units are, of course, invisible; like the atoms, they are beyond the see- 
ing of our microscopes. This nearly unanimous demand on the part of biologists for a complex physical structure of protoplasm, depends largely on the fact that our present knowledge of the chemical constitution of protoplasm offers absolutely no explanation of its capacities. We know that protoplasm is composed of certain familiar elements, present in certain proportions. But beyond that nothing; the actual chemical relations of these component elements are too complex for analysis. Besides, certain observations of the processes of protoplasmic behaviour suggest strongly the workings of a machine whose effectiveness lies in its physical make-up. Finally, the phenomena of heredity seem to admit of no other explanation than the assumption of a composition of the germinal protoplasm out of myriads of structural units actually representing the myriads of cells, or groups of cells, of the fully developed body.

Ever since protoplasm has been recognised as the physical basis of life, therefore, and ever since the germ-cells have been recognised not to be miniature men and women, but, as far as the eye and microscope go, masses of primitive protoplasm differentiated only into cell-plasm, nucleus, and nuclear parts (chromosomes, centrosomes, nucleoli, etc.), there have been "atomic" theories of protoplasmic structure. Unfortunately for the standing of any one of these theories, each working biologist seems to have made one for himself, so that instead of one universally accepted, hence usable and useful, atomic or unit theory such as the chemists have-and the modern physical chemists seem to be rebelling even against that,-biology has had a host of protoplasmic unit theories of which the one we have here specially to refer to is known as Weismann's theory of biophors and determinants. Several of the better known or more ingenious of these theories are outlined in very summary fashion in the appendix ${ }^{4}$ of this chapter. What we need now to know of biophors and determinants in order to 
understand the theory of germinal selection, is this: Weismann conceives the protoplasm of the cell nucleus to be composed of units called biophors-these biophors can also migrate out into the cytoplasm surrounding the nucleuswhich are the bearers of the individual characters of the cell. The total character of any cell, its form, make-up, and special properties, is determined by the totality of its biophors. These biophors are not, however, such simple structures as the atoms of the chemist; indeed, they are to be looked on as super-molecules, as complex groups of chemical molecules, of determined character and arrangement. Moreover, as these biophors are life-units, they possess the essential characteristics of life, that is, the capacity to assimilate food, to grow, and to reproduce themselves by division. The number of different biophors is almost inconceivably enormous; for it must equal the possibilities of variety in character exhibited by, or capable of being exhibited by, all the cells of the body. But as each biophor is made of many complex molecules which may vary among themselves, and also vary in their structural relation to each other inside the biophor, it is not difficult, perhaps, to imagine the possible variety of biophors to be equal to the possible variety of cell characters. These biophors are conceived to be united into fixed, indissoluble groups called determinants, each determinant containing all the biophors necessary to determine the whole character of any one kind of cell. Like the biophors the determinants can assimilate food, grow and multiply by division. While in each specialised bodycell there needs to be but a single determinant, namely, one of the special kind conforming to the special kind of cell, in the germ-cells there must be conceived to be every kind of determinant which may be found in all the body-cells taken together. But, fortunately, by virtue of the determinants' capacity for multiplication it is not necessary to assume that there exists in the germ a 
determinant for every cell that is to develop in the body, but only one for every different kind of cell; all cells exactly alike can be supplied with similar determinants by the multiplication of the proper kind. Now Weismann's theory of germinal selection rests upon the assumption of a competition or "struggle" of the determinants in the germ-plasm for food and hence for opportunity to grow, to be vigorous, and to multiply. The germ-cells derive their food, as do the other cells and tissues of the body, from the general food streams circulating around and through the cells. Weismann, recognising the absolute principle of slight variation everywhere in Nature,-it is practically impossible to conceive of identity,-believes that the initially slightly stronger or more capable determinants will be able to take up larger supplies of food, even to the extent of lessening the supply for neighbouring determinants, perhaps to the degree of starvation. Indeed he suggests a reason for the initial slight variations in vigour of the determinants in the probability that the food will reach the various determinants in slightly, purely fortuitously, variable quantity, so that the first inequality in vigour of the determinants will depend on the fortuitous variability of food supply, while thereafter the variability in the determinants thus produced will enable the stronger ones to draw to themselves or take up more food and thus accumulate determinately the initial fortuitous inequality.

Thus when the germ-cell begins its development into a new individual those kinds of cells, tissues, and organs will be best developed whose determinants were most successful in the struggle for food, while other parts of the body may be made smaller or even may not appear at all because of the starvation of the determinants responsible for the cells which should compose them. Also these better-developed, larger, more vigorous determinants of one generation will hand on to the germ-plasm of the 
next generation strong and extra-vigorous daughter determinants. For any determinant in the germ-plasm of a fertilised egg-cell has not alone to furnish determinants which shall control the development of body-tissues and organs of the individual which develops from this cell, but also to furnish daughter determinants for the new germ-plasm of this individual. This will result in a repetition of the extra-development in the next generation of the same organs as were strongly developed in the first generation, and the under-development of the same organs as were weak or wanting in the first generation. Which process continued is simply determinate variation, that is, variation along fixed lines without reference to personal selec-

Germinal selection results in determinate variation. tion. Now when this variation becomes so marked that it is of life-and-death advantage or disadvantage in the life of the individual, it will immediately become subject to the control of personal natural selection, and under the influence of this dominant factor in determining adaptation, either be further fostered and fixed or be extinguished. If the increasing organ or part due to germinal selection be one whose increase is advantageous to the individuals possessing it, then natural selection will preserve those individuals and the germinal advantage of the determinants of this part will be steadily increased, as the size and power of assimilation of the determinants correspond to the size and vigour of the part.

By this theory Weismann believes that he has explained away one of the most patent objections to natural selection, viz., that it is necessary to assume, for the effective work of selection, the timely appearance of the proper variations necessary for the continued advantageous modification of a part. "Knowing this factor, we remove, it seems to me," writes Weismann," "the patent contradiction of the assumption that the general fitness of organisms or the adaptations necessary to their existence, are produced by accidental 
variations-a contradiction which formed a serious stumbling-block to the theory of selection. Though still assuming that primary variations are 'accidental,' I yet hope to have demonstrated that an interior mechanism exists which compels them to go on increasing in a definite direction, the moment selection intervenes. Definitely directed variation exists, but not predestined variation running on independently of the life conditions of the organism as Nägeli, to mention the position that the most extreme advocate of this doctrine has assumed: on the contrary, the variation is such as is elicited and controlled by those conditions themselves, though indirectly."

Obviously Weismann in his theory of germinal selection has preserved the actuality of a struggle and a selection, but with a "rehabilitation" of natural selection in the real Darwinian meaning and only fair application of the phrase the new theory has nothing to do. It is, much more, a distinct admission of the inadequacy of natural selection to do what has long been claimed for it. It is the first serious attempt at a causo-mechanical explanation of a theory of orthogenesis, that is, variation along determined lines.

As to our acceptance or non-acceptance of such a theory we need say little. It consists of two purely speculative basic assumptions: First, Weismann's particular theory of the ultimate structure of the germ-plasm, namely, the theory of biophors and determinants; and secondly, the assumption that there is a struggle for food among the determinants. There is no proof of pure observation or experiment for the theory, and there is some proof directly against it. And yet the great need of a working hypothesis for the causomechanical explanation of determinate variation makes us give such a pure speculation more attention than it might otherwise get. Unfortunately the attention thus given to this particular theory seems to have resulted in the bringing forward of some rather serious objections to the possibility 
of the truth of the theory. A few of these objections ${ }^{\circ}$ may be briefly stated.

According to the theory there should be plainly exhibited in the variation of any species, decided tendencies in certain

objections to specific directions. In all species, in all inditheory of ger- viduals, the struggle of the determinants must
minal selection. result in the suppression or reduction of some, the extra-development of others. Thus variation should not reveal itself according to the law of error, that is, should not be distributed normally about a mean or mode. But that is exactly the condition of variation in a majority of those cases in which the variation of one or more organs in any species has been statistically studied. The plotted curve of any particular variation of this type is a symmetrical curve nearly coincident with the theoretical one expressing the law of error for the same case.

The constancy of species is just as marked and actual a condition as the condition of slight fluctuating variations inside the species. This constancy is steadfast for considerable time-periods. But with such an active orthogenesis as the theory of germinal selection provides, there could be no such steadfast constancy. Weismann himself recognised the weight of this objection to the theory, and speaks of an attribute of "self-correction" pertaining to the germplasm, which shall regulate or check too rapid an orthogenetic development.

The actual change of the competitive determinants due to their obtaining an over or under supply of food should be one simply quantitative in degree; such germinal selection could thus lead to the change in size and strength of organs already present in the species, but could offer no explanation of qualitative changes, $i$. $c$., the appearance of new kinds of structures. Moreover, even in cases of purely quantitative change, such familiar cases as the persistence through long time-periods of small, rudimentary organs, 
without any indication of further reduction, indicate a peculiar cessation in the forthright working of germinal selection. Why should not the weak determinants of these weak organs go completely to ground in the struggle?

Actual experimentation on the influence of food-supply in development does not bear out the assumption on which the theory of germinal selection rests. Weismann himself gave the larvæ of flies, and I have given the larvæ of silkworms through their whole life-time, an abnormally small fond supply (in the case of the silkworms this supply was from one-fourth to one-eighth the amount normally eaten by full-fed larvæ), with the only result that the mature individuals were dwarfed; that all their parts were reduced in size, but the actual size proportions of the various organs. and parts, and their relations to each other, were unchanged. The determinants seemed to share equally the hardships of short rations rather than a few of the stronger getting the better of the weaker. From the eggs of birds considerable quantities of yolk have been withdrawn without modifying appreciably the individuals developed from the eggs.

If the struggle of the determinants is really an actual and severe one then only those of the large strong organs should survive, all the others being starved out. Such a condition would result in the exclusive development of monsters, i. $\mathcal{c}$., individuals lacking numerous organs (the small ones), and with the large ones all over-developed.

Rourr's Theory of Intra-selection or the Battle of the Parts.-Distinctly more likely to appeal to our reason is the theory of Roux, ${ }^{7}$ proposed in I88I, to explain how one or more organs may exhibit a progressive development or increase in size and capacity without reference to natural selection and also to account for the many remarkable adaptations of slight and delicate but extremely precise character exhibited by various internal organs. Roux made, however, a too radical distinction between external or superficial 
adaptations on the one hand, attributing these to the influence of natural selection, and the adaptations of internal parts on the other, which he would attribute to the influence of his functional stimuli and of his struggle among the inner parts of the body. This struggle, like that among Weismann's hypothetical determinants, is one chiefly for food, but in Roux's theory there is no assumption of hypothetical life units, nor any lack of clearness concerning the initiation of the actual struggle. The competing parts in Roux's theory are the chemical molecules composing the The competing cell, the cells themselves, groups or tissues of parts in Roux's cells, and even whole organs. The spurs to the ally recognised competition for food are functional stimuli, stractures. whose result is to set up a special demand and necessity for more food. Roux's classic example will make this clear. It is a matter of fact that the fine plates and layers of bone in the "spongy tissue" of the long bones of the body, are so disposed as actually best to withstand the stresses most usually brought to bear on the bones. Thus they show a fine adaptation of arrangement, which one meets difficulties in trying to explain as due to natural selection. For, if we imagine the thin plates of the spongy tissue purely miscellaneously arranged, the possible slight variations whereby a few plates at a time might fortuitously occur in a position or direction better fit to strengthen the whole bone, are so insignificant in proportion to the condition throughout all the rest of the bone that we cannot possibly attribute to them a life-and-death value in the individual's struggle for existence. Roux assumes that the stresses brought to bear on the bone during its development act as functional stimuli to all those plates in the forming spongy tissue, which lie in such places or at such an angle to the stress as to be affected by them, and in response to these stimuli, which in Roux's belief are necessary to the normal structural development and maintenance of any part, these 
forming bony plates will take up more food than the unstimulated ones, and thus will be developed at

The stroggle the expense of these others. Similarly with all those other marvellously delicate inner adaptations of fine and minute and oft-repeated structures to the special functions of the organs containing these structures. The stimulus of the function excites a trophic demand on the part of the struggle and an actual capacity for satisfying the demand, that soon leads to the extra-development of the stimulated parts at the expense of adjacent similar parts deriving food from the supply common to all. Thus Roux would explain the exquisite adaptation of the arrangement of the muscle-fibres in the walls of the blood-vessels, the tænidia or spiral threads in the tracheæ of insects, the little barbs on the feathers of birds which hold these feathers together in almost air-tight continuity, the numerous protective hairs covering the spiracles of many insects, etc., etc.

It will be noted that the competition of the parts is really twofold; thus, while for successful development it is neces-

The struggle twofold. of the parts is

sary for parts to be successful in food-getting, this success in food-getting seems to depend upon the prerequisite of receiving a needed functional stimulus. Thus there may be said to exist a competition for functional stimuli. But obviously success in this competition depends chiefly on the hazard of position. Those plates in the forming spongy tissue of a long bone which happen to lie where the stress comes, and in a special direction to be affecied by it, are the winners in the competition for stimuli.

Roux's theory has appealed strongly to many biologists, but others have rejected it wholly, or at least as an explanation of fine inner adaptations. Plate takes this

Plate's criticism of Roux's theory. latter position, but finds a great service in the theory in that "Roux has given in it a profound analysis of the well-known fact that use strengthens and 
disuse weakens. His is the great merit of having clearly explained the extraordinary importance (Tragucite), in the building of new forms and adaptive structures, of this elementary attribute of organisms. We have to thank him for the best putting together of all those observations which permit of but the one conclusion, that the functional stimuli exercise a trophic activity, that is, that each organ by the constant exercise of its function becomes stimulated to stronger assimilation and increased multiplication of its elementary parts, and that ont of this there results a heightened functional capacity." However, as Plate points out,

The law of this "law of functional adaptation" does not functional adap- apply to all organs and tissues; "the teeth of apply to all many mammals become impaired through conorgans.

stant use, and most of the sense-organs are apparently not bettered through use in regard to their perceiving elements but only in regard to their carrying elements. Every exercise is followed by a certain fatigue which, in cases of exhaustion, is greater than the aimed at (ersiclte) increase of functional capacity. Also the trophic stimulation can, in certain cases, lead to hypertrophy and other unadaptive results." But as regards the actual "struggle of the parts," and especially as regards the claim that such a struggle is to account for inner adaptations, Plate, as a consistent natural selectionist, is wholly sceptical. He offers five objections to any usurpation of the functions of natural selection by this intra-selection theory. First, he holds, with Wolff, that it is impossible to place the inner adaptations in any sharp contrast with onter adaptations. They are contrasted only in that the former stand in a more indirect relation to the conditions of life. Indeed a single organ, as a claw for example, can show an external adaptiveness in that it might be especially well arranged to scratch hard dry ground, and at the same time be distinctly adaptively constructed as regards its fine inner structure. "If 
natural selection," says Plate, "is capable of producing outer adaptations such as making the fur of a mammal thicker and thicker as a protection against the cold, why can it not increase, or if advantage lies the other way, decrease, the number of bony plates in the spongy tissue of the long bones?"

Second, the capacity of living substance to be stimulated to increased food-getting is an elementary attribute of organTrophic stimu- isms just as the capacities to assimilate, to be lation notex- irritable, and to breathe are. This special plained.

capacity is not explained by the theory of intraselection; it is, indeed, just now wholly inexplicable. One might perhaps fairly assume that it is the result of a gradual development from the Protozoa onward, through the influence of individual selection. But this is no explanation of its origin. Roux, himself, indeed, expressly declares that he bases his theory on the proved but not explained fact of functional adaptiveness, but some of his followers often forget this and seem to claim that the distinctly advantageous peculiarity of most tissues to be able to increase in strength and size through use is a direct result of the battle of the parts.

Third, Plate holds that the battle of the parts plays no rôle in ontogeny. The cleavage and embryonal develop-

Battle of the ment are wholly controlled by heredity, so that parts noterident there is nothing left for the battle of the parts. in ontogeny. There occurs a peaceful and regular splitting apart of the single cells and a separation of them according to their different qualities, and it does not at all occur that the strongest cells get all the food and the weakest none, but on the contrary each receives as much as it needs for its growth. In a blastula of thirty-two cells it is not the capacity on the part of certain cells which results in the stronger growth of some and the weaker growth of others, or the more rapid multiplication of some and the 
less rapid of others, but, on the contrary, for each species there is a definite law of growth which we may only explain as the expression of a force of heredity, not capable yet of analysis. Matters certainly do not go on in an embryo as in an agar culture containing several kinds of bacteria of which only that one with the greatest life force remains. Were the development of the embryo determined by the food-zeal of the cleavage cells, it would happen that in a short time a few cells specially capable of assimilation would get the upper hand, and as a consequence only a few qualities be left to the embryo; a real differentiation into thousands of different cell-sorts would not be possible. All the facts of symmetry and auto-regulation in embryonic development speak against any considerable influence of a battle of the parts during development.

Fourth, Plate declares that in the acquirement of new characters no selective intra-struggle takes place, or at least

No battle of the parts in the acquirement of new characters. in only most insignificant manner, but that the new structures arise either through the direct influence of new stimuli or by natural selection of new germinal variations of unknown origin. In the first place it is simply the matter of position, not at all that of quality, that decides whether the certain cells shall be changed or not. Think, for example, of a vessel in whose walls the connective tissue fibres cross and recross in all directions wholly without order, and conceive that a constant or repeated stress in both longitudinal and transverse directions is exerted on this vessel. It would result that all those fibres lying in the absolute or approximate directions of these stresses would be most stretched and would in consequence of their trophic irritability most rapidly enlarge and increase with special rapidity. Now by the repetition and inheritance of this result of use it would finally come about in the course of generations that all the fibres situated in other directions to the stresses would die out, 
and thus a definite longitudinal and transverse arrangement of fibres in the walls of the vessel result. Without doubt, holds Plate, much advance is won in this way, but this specialisation of structure is not a result of intra-struggle but rests on the elementary attribute of trophic irritability. Not the best-qualified but the best-situated fibres have vanquished the others by robbing them of food and thus finally destroying them. In the second place, "many inner structures belong to the great category of passive adaptations; they function only through their presence and cannot thus be further developed by use or disuse, that is, by functional stimuli, but only by natural selection. Here belong, for example, the stratification of the lens in the human eye, the apodenes (inner projections of the chitinised cuticula) which protect the ventral nerve-cord of the crabs, the chitin hooks which hold together the fore and hind wings of many insects, and the similar structures which bind together the secondary branches of the feather vanes of birds. These inner adaptations cannot have resulted through the influence of light or of nervous function or flight. There is but one explanation possible; namely, that natural selection has seized on and developed fortuitously appearing germinal variations. But if natural selection can produce such inner adaptations why can it not then produce all the others?"

Fifth, Plate points out that Roux's theory is based on the inheritance of those special body characters which are

\section{To accept}

Roux's theory is to accept the inheritance of acquired characters. acquired through the battle of the parts-more rightly, Plate holds, through functional adaptation,- - so that to accept the theory, one has to declare, to that degree, a belief in the inheritance of acquired characters. Thus from the start, the neo-Darwinians cannot accept the theory.

After all what is this theory of Roux's but a refinement, a special case, of the broader and more general long-known Lamarckian theory of the modifying and formative influ- 
ence of use and disuse, accumulated through inheritance? That is, if we accept Plate's analysis that the theory is

The battle of the parts theory is a special case of Lamarckism. really not one of a battle of the parts, but of the effects of functional stimuli. And however the proposer of the theory may protest against such an apparent violent setting over of it from the category of selection (Darwinian) theories into that of the inheritance of use (Lamarckian) theories, I believe that most of us will see the justness of Plate's analysis. I do not believe that Roux's theory in any way strengthens the selection conception. To my mind, indeed, it is simply a concession of the inadequacy of selection to initiate adaptation, and a welcome and satisfying explanation of how such an initiation may occur in many cases, in certain cases, that is, of active adaptations. Plate's argument that natural selection must be the only explanation for the cases of passive adaptations and hence may be held capable for accounting for the active ones, has no conviction for me, for I do not believe that natural selection is the only possible explanation of the passive cases. In fact, I cannot conceive it to be a possible explanation of the initiation of these cases. And I am glad to find in Roux's theory-even if it be not exactly applied in Roux's own sense-a mechanical explanation of the possibility of initiating certain fine and delicate inner adaptations.

Organic Selection.-An interesting attempt to escape from the difficulties which are imposed on one by an absolute adherence to Weismann's doctrine of the impos-

Organic selection, orthoplasy, or ontogenetic selection. sibility of the inheritance of acquired characters coupled with a belief in the inadequacy of the slight fluctuating germinal variations to afford handles for the action of natural selection, is the theory variously called organic selection, or orthoplasy, proposed by Baldwin ${ }^{8}$ and Osborn ${ }^{9}$ in America, and Lloyd Morgan ${ }^{10}$ in England. This theory, which might also be called one of 
"ontogenetic selection," or of "coincident selection," is that the personal selection, or individual survival, among individuals of a species does not necessarily depend solely upon congenital variation but may, must, indeed, depend on any ontogenetically acquired adaptations as well. As in many cases these ontogenetic adaptations are considerable, they will often carry individuals through very critical periods in their lives. But the individuals showing these ontogenetic adaptations in best degree will be those which actually possess certain slight congenital variations, especially of the nervous system or coördinating nerve centres, "which lend themselves to intelligent initiative, adaptive, or mechanical modification during the lifetime of the creatures which have them." The ontogenetic adaptations may occur regularly in the lives of successive generations of individuals if the environment remains fairly constant. During these successive generations the congenital variations of brain, say, which make the successful ontogenetic adaptations possible, will by selection of the best ontogenetically varying individuals be themselves selected, and the species thus gradually be modified in a determinate direction. Also congenital variations of nearly the same nature as the ontogenetic variations, or of a nature to supply the same need, will have time (that is, more chance. because of the longer time and repeated generations) to appear. In this case these advantageous variations can be transmitted directly by heredity, and thus a permanent adaptation be effected which will seem to be the result of the inheritance of an acquired character (i.e., the similar ontogenetic modifications) but which in reality is only the normal inheritance of a congenital variation.

In the language of all the sponsors for this theory there seems to be a suggestion of the piling up or adding together of congenital variations, not simply those of brain or other control centre which make the ontogenetic modifications possible, but also of these modifications themselves during the 
successive generations through which the species is safely carried by the temporary regularly appearing ontogenetic adaptations. But there is nothing in strict neo-Darwinism to permit of any such idea of increase. Such moving forward without the aid of selection can only be explained by the adoption of some theory of orthogenesis. Either the congenital variations are of such a character that the resulting ontogenetic modifications are not fairly to be distinguished from them, in which case they are assumed to be large enough from the start to afford handles for natural selection (which the proposers of the theory are not claiming), or they depend for their preservation on a kind of happy coincidence in occurrence with similar more effective ontogenetic modifications which are really large enough to save the life of the organism and hence the slight congenital variations along the same line. But in this latter case organic selection cannot demand much discussion until it explains away a

Delage and radical failing pointed out clearly by Delage Plate's criticisms and Plate. This is simply that, in the face of
of organic selecof organic selec- the large character which ontogenetic adapta-
tion. tion may and often does possess, those individuals in which the slight congenital variations in the right direction finally appear will have no special advantage over those in which they do not appear; the large and effective character of the ontogenetic adaptations, which are common to both kinds of individuals, being quite sufficient to determine the result of personal selection. The congenital variations will be too small in comparison with the ontogenetic variations to cut any figure in the fate of the individuals, and there is no reason at all to believe that individuals showing the slight congenital variations in the right direction will be the only ones to show the saving large ontogenetic adaptations. Plate suggests the following case to show the inutility of this theory: Suppose an antelope species to have a leg muscle averaging seven $\mathrm{cm}$. in thickness, and several individuals to 
show a congenital variation bringing the leg muscle up to eight cm. of thickness. Now if it requires a leg muscle of eight $\mathrm{cm}$. for safety, as a matter of fact almost all the individuals of the species will quickly bring their leg muscles up to that size by use. But suppose the actual need for safety was a leg muscle of fourteen $\mathrm{cm}$., then only those individuals specially capable of that ontogenetic adaptation, $i$. e. (modification of the leg muscle by use and trophic irritability), up to fourteen cm., would be saved; and undoubtedly among these the original eight $\mathrm{cm}$. individuals ought to stand in slightly higher numerical proportion (in regard to their original numerical standing in the species) than the originally seven $\mathrm{cm}$. individuals. Since, however, these eight $\mathrm{cm}$. individuals originally existed only in comparatively small number, and since they possess no special means of recognising each other and distinguishing each other from the original seven $\mathrm{cm}$. individuals, mixed mating will inevitably soon swamp the original congenital increase of one $\mathrm{cm}$. in muscle thickness.

In connection with the explanation of this theory it will certainly occur to some of my readers, as it has to me, to ask Danger of if it is not a dangerous proposal to give to assuming too ontogenetic adaptations a greater worth in

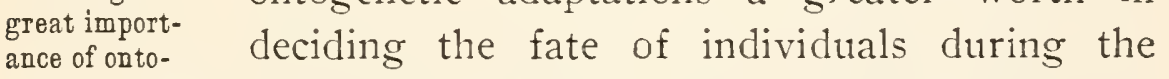
genetic selection. struggle for existence than the congenital variations. Is this not proposing to take away from the fluctuating, individiual, so-called Darwinian variations practically all worth and capacity except as they are of immediate use to the just-born individuals, $i$. $e$., before the ontogenetic adaptations have been able to develop? Indeed, why is it not a perfectly legitimate and a serious criticism of congenital fluctuating variations that they must be overshadowed, hidden, and overwhelmed by the quick and large ontogenetic or individual modification of which practically all organisms are capable? Why will not those individuals born with the 
better and larger capacity to adapt themselves during their ontogeny to their needs win in the struggle for existence rather than those born with predetermined slightly larger leg, slightly stronger muscle, etc.? What is needed is capacity to develop by use and functional stimulus a much stronger muscle, a much swifter flight than the average. Those individuals that are capable of such considerable and really worth while ontogenetic adaptation will win in the struggle for existence; and while they may not hand down by inheritance their actually acquired characters, will they not hand down their inherited congenital capacity for considerable and effective ontogenetic adaptation?

\section{APPENDIX.}

${ }^{1}$ For a fairly complete bibliography, with abstracts, of all the important discussions of species-forming theories published since I895, see L'Année Biologique (ed. Y. Delage). For bibliography and abstracts, also see Zoologischer Jahresbericht, issued annually by the Naples Zoological Station. See also discussions and notes in various biological journals, as Biologisches Centralblatt. Natural Science (now discontinued), Nature, Science, American Naturalist, etc.

'For a careful account and discussion of Weismann's work and theories as far as developed up to I893, see Romanes, "An ExamiList of Weis. nation of Weismannism," I893. Weismann's presmann's evolution ent-day position and his arguments for the selection papers. theories are set out in his "Vorträge über die Descendenztheorie," 2 vols., I902, which we may look on as constituting a manual of neo-Darwinism, treating all the more familiar bionomic phenomena and conditions as explained by selection. The following is a chronological list of the more important of Weismann's publications:

"Über die Berechtigung der Darwin'schen Theorie," I868.

"Über den Einfluss der Isolirung auf die Artbildung," I872.

"Studien zur Descendenztheorie: I, Über den Saison-Dimorphismus der Schmetterlinge," I875.

"Über die Dauer des Lebens," I882.

"Über die Vererbung," I883. 
“Über Leben und Tod," I884.

"Die Continuität des Keimplasmas als Grundlage einer Theorie der Vererbung," i885.

“Über den Rückschritt in der Natur," I886.

"Über die Bedeutung der Sexuellen Fortpflanzung für die Selectionstheorie," I887.

"Über die Zahl der Richtungskörper und über ihre Bedeutung für die Vererbung." I887.

"Botanische Beweise für eine Vererbung erworbener Eigenschaften," I888.

"Über die Hypothese einer Vererbung von Verletzungen," I889.

"Bemerkungen zu einigen Tages Probleme," I8go.

"Gedanken über Musik bei Tieren und beim Menschen." ISgo.

"Aufsätze über Vererbung und verwandte Biologie," I892. (This includes the eleven preceding papers now published in bookform. These essays have also been translated into French, by $H$. de Varigny, and published under the title: "Essais sur l'Hérédité et la Sélection Naturelle." I892; and also in English as "Essays upon Heredity and Kindred Biological Problems," trans. and ed. by Poulton, Shoneland, and Shipley, 2 vols., I $89 \mathrm{I}$ and 1893 .

"Amphimixis oder die Vermischung der Individuen," I89I.

"Das Keimplasma; eine Theorie der Vererbung," I892; Eng. trans., by Parker and Ronnfeldt, as "The Germ-plasm; a Theory of Heredity," I $\$ 93$.

"Die Allmacht der Naturzüchtung, eine Erwiderung an H. Spencer." I893: also in English as "The All-sufficiency of Natural Selection," in the Contcmp. Revicw, Vol. LXIV, pp. 309-338, 596-610, I893.

"The Effects of External Influences upon Development," Romanes Lectures. I894: also in German as "Aussere Einflüsse als Entwicklungsreize." I894.

"Neue Gedanken zur Vererbungsfrage," I894.

"Über Germinal-Selection," in Compt. Rendus, 3d Congress Internat. Zool., I896; also, in English, trans. and ed. by McCormack, as "On Germinal Selection as a Source of Definite Variation," I896.

"Thatsachen u. Auslegungen in Bezug auf Regeneration," Anat. Anzcig.. Vol. XV, I899.

"Vorträge über Descendenztheorie." 2 vols., I902; also in Eng., trans. by J. A. Thomson as "Lectures on the Theory of Descent." 2 vols.. 1904.

${ }^{3}$ For a detailed critical discussion of panmixia, see Wolff, "Der gegenwärtige Stand des Darwinismus," I8g6. 
${ }^{4}$ Various theories of ultimate protoplasmic structure have been proposed to explain what is not really known about this substance.

Theories of ul- These theories refer almost exclusively to the physitimate protoplas. cal, rather than the chemical, make-up of protoplasm, micstructure. and for the most part have been proposed with special attention to the germ-plasm, $i$. e., the protoplasm of the spermand egg-cells. The spur to the formation of these theories is the necessity that biologists have felt imposed on them from the beginning of the study of heredity and development of offering some rational explanation of those phenomena. That from a single germcell formed by the fusion of a sperm-cell and an egg-cell from different parents, a complete new organism composed of millions of cells of manifold variety of specialisation and arrangement can develop, is wonder enough; but that this new organism shall repeat in all its parts with extraordinary fidelity the structure and physical idiosyncrasies of one, or show a combination of the characteristics of both, of the individuals from which came the original single sperm- and single egg-cell, adds wonder to wonder. What physical or structural basis is there in the fertilised egg-cell that it can represent in its tiny self the whole of a giant body, like that of an elephant, whose every detail it can, by a process of development under suitable extrinsic conditions of temperature, food-supply, etc., repeat in a new creature. The answers to this, all purely speculative, or more fairly theoretical, because some of the answers at least have been guarded in their forming by all the care which a rigorous scientific attitude toward hypothesis demands, are many and various, and date from the days of the Greek philosophers to the present hour. It would take too much space and carry us too far afield to attempt anything like an explanatory list of even all of the better known of these general theories of the invisible ultimate structure of the germ-plasm here, but by selecting seven or eight types of the principal categories or kinds of these theories, and briefly explaining them, we may have at least some conception of the attitude that biologists take toward this great problem. The reader who has a fancy for following this subject further is referred to the admirably full and lucid treatment of it in Delage's great work, "L'Hérédité" (2d ed., pp. 43I-772, I903).

Most of these theories include much more in them than a simple speculation as to the ultimate structure of the life-substance; they attempt to explain all the phenomena of life, motion, nutrition, growth, reproduction, development, heredity, variation, etc., with reference to some assumed ultimate make-up of the primitive lifesubstance, and the relation of this structure to the known physicochemical forces and conditions of Nature. Most of the older 
theories assumed a peculiar vital force, which is not assumed in the later ones, although exception must be made to this statement in favour of the point of view held by the recent so-called neo-Vitalists, those present-day workers who admit the hopelessness of trying to reduce all vital phenomena to a physico-chemical basis.

An old type of theory of heredity and structure of the germplasm, widely held in the seventeenth and eighteenth centuries, is Encasement that of the "encasement of the germ" in one of the theory. germ-celis, either the spermatozoid or the egg. The essential part of this theory is that the new organism is assumed actually to exist in miniature, with all its parts present, in one of the germ-cells, and in this miniature body must exist, by repeated encasement, all its future progeny. Whether the believer in this theory considered the tiny new creature, only needing to swell and grow to be complete, to be encased in the sperm-cell or the egg-cell, ranked him respectively with the spermatists or the ovalists. A vigorous strife raged between these two factions among the upholders of this simple and effective explanation of heredity which led to certain interesting compromises. A commonly held one was that the sperm-cell furnished the spiritual element, the egg-cell the material and mechanical elements of the new creature. Another, held by Linnæus, the great botanist and father of biological classification, was that, in plants, the egg (ovule) furnished the internal and reproductive organs, while the sperm-cell (pollen) furnished the external and vegetative parts. De Candolle, another great botanist, held just the reverse of this view. All these theories of an actual encasement in the germ-cells of a whole or part of a new organism were not mere guesses, but were based on what men thought they saw through their microscopes. The long reign of these theories, now shown to be utterly absurd, illustrates well the constant danger which attends our attempts in all biological study to interpret what we see when working at the limits of visibility. With our much-improved microscopes we laugh at the fantasies which the microscopic vision of our eighteenth-century co-workers raised up. Who may say that our own interpretations of plasm-structure may not seem as absurd to the biologists of the next century?

By far the great majority of theories of ultimate protoplasmic structure belong to what Delage calls the category of theories of Micromeric micromerism. Which means simply that all these theories. theories assume a composition of the plasm out of minute ultra-microscopic units of structure, which are also units of life, for all these units are presumed to be endowed with the essential life-attributes. These units may be looked on, as they were by Buffon, as universal, indestructible, hence immortal, parti- 
cles, or, as they are in most of the micromeric theories, as living particles which are destroyed with the death of the organism which they compose. In this latter type of assumption the units are, according to some theories, all of the same nature, all exercising an equal influence in determining the character of a developing organism (Spencer, Haacke. His, Cope); or they are, as assumed in other theories, of various character and charged with various functions. This latter kind of unit is held by some authors to be actually representative either of ancestral plasmas (Weismann) or of the actual body-cells of the parent (Darwin, Galton, Brooks, Hallez), or of elementary characteristics and functions of the organism (Nägeli, Kölliker, de Vries, O. Hertwig), or at the same time of both body-parts and elementary characteristics (Weismann's latest theory).

Buffon's theory assumed that "the substance of which organisms are composed differs essentially from that which composes the Buffon's inorganic bodies. Organisms are composed of special theory. particles, the organic molecules. These molecules are universal and indestructible: universal in that they exist everywhere where life has access, indestructible in that death and the dissolution which follows destroy the organisms, break down the molecular combinations which constitute them, but do not reach the molecules themselves. These are only separated, put at liberty, but remain ready to enter into new groupings. While they cannot be destroyed, neither do they increase in numbers. They form nothing actually new, either spontaneously, or by means of old ones, so. that, measured by these organic molecules, the total quantity of life in the universe is invariable" (Delage). Nearly a hundred years later Bechamp (I883) proposed a theory similar to Buffon's in which he assumed the composition of organisms out of minute elementary living particles called microzymes. Like Buffon's organic molecules they are indestructible, and they are strewed in innumerable numbers through earth. air, and water. They owe their origin to special creation by God.

Of the non-immortal kind of micromeres Spencer's physiological units represent a general type favoured by numerous theorists: namely, living units all of the same nature and active because of their polarity, their form and molecular forces, or their vibratory motion. Spencer's physiological units are active because of their polarity, but the annular atoms of Dolbear's theory and the plastidules of the slightly varying theories of Haeckel, His, Cope, and others, owe their active properties to their vibratory motion.

According to Spencer (I864), there exist between the cells (morphological life-units) and the molecules which compose them 
(chemical units), units of a third order (physiological units) comSpencer's posed of groups of molecules. These units are very theory. small but very complex, and are the smallest masses in which living substance can occur. Most of the micromeric theories, which come after Spencer's, adopt this conception of a life-unit, very small, but composed of an aggregate of molecules, and therefore very complex. To his physiological units Spencer attributed a polarity, wholly analogous with that possessed by the molecules of crystalline substances. It is owing to this delicate, precise polarity, varying of course with the varying molecular constitution of the units, that they possess the capacity of actively arranging themselves in the varied groupings normal to the parts of the organisms. "Thus the resemblance is perfect between the chemical polarity which causes crystallisation and that of the physiological units which produces the form of organisms. In one case the chemical molecules group themselves in a manner to form an aggregate of definite but simple form, cubical, prismatic, rhomboidal, with their parts arranged en tromies, aiguilles, croix de Saint André, boules épincuses, etc. In the other the units group themselves in a body of a form less rigorously defined but which may be very complicated: such as a plant or an animal." (Delage.)

Of the theories in which the living units are assumed to be of different kinds, and endowed with different functions, some assume the units to be not directly representative of different cells or parts. of the body, while others assume this truly representative condition. Of the first sort are a number of theories like those of Berthold, Geddes, and others, in which the units are taken to be actual chemical molecules, endowed with activity through special physicochemical properties or through purely chemical ones, while still others keep to the more usual type of a unit of a higher order than a molecule, in which case also this unit is looked on as specially active because of particular electrical (Fol) or chemical (Altmann and Maggi) or vital (Wiesner) endowment. But all of these theories are much like each other and are much like Spencer's. theory in regard at least to the assumed units. Different, however, is the type of theory which introduces the assumption that the fundamental life-units are directly representative of either the specific cells, parts, or elementary characteristics of the organism. This is the kind of unit especially favoured by the men who had, in their formation of a theory, a special eye to the problem of heredity. How is the single germ-cell to be the bearer of the "heredity" of the organism from which it comes? what more simple to assume than that this cell shall be composed of minute particles gathered from all the cells or groups of similar 
cells of the body of the parent? And that is precisely the characteristic assumption, dressed up in an ingenious variety of form, which charac.erises the theories of life-units most favoured at present: such theories are those of Darwin, Galton, Brooks, Nägeli, de Vries, Hertwig, and Weismann. In some of these, interesting attempts are introduced to connect the assumed structure with the actually observed finer structure of the nuclear protoplasm, by introducing combinations of the fundamental units, in one or two, or even three, successive degrees until an aggregation is reached which corresponds with those microscopic structures, the chromosomes, or chromatin granules or threads, which are actually visible to the microscope-aided eye. The most recent one of the theories of this general type is that of Weismann's biophors and determinants structure of the germ-plasm, already explained in connection with the presentation of his theory of germinal selection (see pp. I93 ff.). As other examples we may note especially Darwin's, called the theory of the pangenesis of gemmules; and Nägeli's, called the theory of micellæ and idioplasm.

Darwin's gemmules are extremely minute particles, which are formed in all the various cells of the body and are capable of reproDarwin's ducing themselves rapidly and in great numbers by theory. repeated division, and which, by virtue of their minute size and an innate activity due to a sort of affinity or attraction existing between them and other substances, move about freely in the body, penetrating any membranes, and arranging themselves with a delicate precision just where they are most needed. When a gemmule enters an undifferentiated or developing cell as yet containing no other gemmules, it controls the development of that cell so that it becomes a cell of the type from which the gemmule had birth, each gemmule representing thus exactly the characteristics and the type of its mother cell. Thanks to the delicate and precise adjustment of affinities, migrating gemmules only enter those cells which they really should enter in order that a normal development of all the cells of the body should go on. But those few cells of the body which are destined to become germ-cells, that is the spermatozoids and eggs in animals, the pollen grains and ovules in plants, receive during their formation gemmules from all the other cells of the body. Not only from all the cells of the fully developed body, but from all those ephemeral cells which arise and live for a while during the ontogeny of the parent, performing certain special functions and then making way for the definitive cells of the mature organism. Thus in the germ-cells are stored actual physical representatives of all the cells which have existed during the whole life of the parent body. These innumerable gemmules remain inactive 
in the germ-cells until, after fertilisation, the egg-cell begins its development. Then as the cells of the new organism begin to be produced, the gemmules become active and each one moves into the cell it should control and there directs its further development into precisely the kind of cell it should be at precisely the time it should be this kind of cell, until there results from this gemmulecontrolled development a photographic reproduction of the parent body.

Nägeli's conception is that when the complex life-characterising albuminous substances took their birth in an aqueous liquid, they would Nägeli's be precipitated, as they are not soluble in water. This theory. precipitate is formed of small masses, a sort of organic crystals, which may be called micclla. And just as an inorganic crystal deposited in a saturated saline solution of the same nature determines the deposit on its surface of the dissolved molecules in the form of little crystals, and by this means grows, so wherever any micellæ are formed they facilitate within their sphere of influence the precipitation of others, so that this production of micellæ instead of taking place miscellaneously through the liquid will be localised at certain points. Thus arise aggregates of albuminous substance, in the condition of micellæ, forming the primitive protoplasm. The micellæ, although insoluble in water, have a great affinity for it, and each one at the time of its precipitation fixes around itself a thin layer of water, at least as thick as a water molecule. Thus, all the micellæ grouped together in a bit of primitive protoplasm are separated from each other, and also held together by a layer of water as thick as two water molecules. This water forms an integral part of the protoplasm. By virtue of it. an aggregate of albuminous micellæ can increase by intercalcation as well as by the addition of new micellæ on the outer surface. By admitting more or less water the protoplasmic mass may become more or less nearly fluid. Thus are accounted for the various densities always met with in the different parts of a protoplasmic cell.

A further essential part of Nägeli's theory is an arrangement of the primitive protoplasm in two ways, resulting in two kinds of it, which are called nutritive plasm and idioplasm respectively. This arrangement depends on the molecular forces pertaining to the micellæ, and the difference, resulting in two kinds of plasm, depends upon the relative situation of the micellæ composing the mass, just how this affects them differently, however, not being made very clear. But the differentiation is very important, for it is the idioplasm alone which contains the essential life-properties and which really gives rise to life with all its variety and complexity. This idioplasm 
is formed at first in scattered bits in the nutritive plasm mass, but as these bits increase they join and become united into a network surrounded by and containing in its meshes the nutritive plasm. And one of the most interesting parts of Nägeli's hypothesis is that he conceives this network of idioplasm not to be limited by cell boundaries but to penetrate from one cell into adjacent cells and thus to spread through and unite in a most significant and important way all the cells and tissues of the body. It is just this sort of a ramifying, stimulus-carrying, protoplasmic network connecting all the parts of the body that the believers in the inheritance of acquired characters seem to need as a mechanism to transmit from soma to germ-cells the effects of external and functional stimuli.

Next, the theory of intra-cellular pangenesis of de Vries may be briefly stated. This theory has become the more important because of the great interest aroused by and the large appreciation given to the mutations theory of species-forming of the same biologist. De Vries's theory of intra-cellular pangenesis has much in common with Darwin's theory of the pangenesis of gemmules, but it is able to do away with that particularly weak part of Darwin's theory, which postulated the circulation of the gemmules throughout the organism in order that they should meet in the germ-cells and modify these cells in a parallel way with the modifications occurring in the peripheral organs. Darwin had to postulate this circulation of the gemmules through the organism in order to explain the phenomena of regeneration, and the heredity of acquired characters. Now that the heredity of acquired characters has been shown to be at best an extremely doubtful phenomenon, and that regeneration is explicable by other means, de Vries has been able to drop this weakest part of the Darwinian conception. So that in the theory of the later biologist, the circulation of gemmules does not extend from one cell to another throughout the body of the organism, but limits itself to that particular cell in which it is created and circulates only between the nucleus and cytoplasm, from which comes the name, "intra-cellular pangenesis," as distinguished from Darwinian pangenesis. De Vries' theory may be abstracted as follows (following Delage):

The form and properties of cells result from their protoplasmic composition just as the properties of the inorganic bodies result

De Vries's from their chemical composition. Is it necessary, then, theory. to admit that there are as many kinds of protoplasm as there are different sorts of cells in the organised beings? When one recalls how many different cells there are in a single organism, and that the homologous cells are not identical in different species, one. 
realises the incalculable number of these cells and despite the richness in variety of proteid substances, it will be impossible to conceive that each kind of cell should have its own kind of protoplasm. There is here, apparently, an insurmountable difficulty, but one which it is easy to do away with by a very simple conception. This conception consists in distributing the complex characters and properties, innumerable in living beings, into elementary characters and properties much less numerous, which, by varying combinations, produce the almost infinite variety that we observe in the inorganic world. Just as with a score and a half of letters one may form all of the words of the human language. so with the elementary properties of which the actual number is still very considerable, one may reproduce all the characters of living beings in all their variety and complexity. It suffices, then, to admit that these elementary characters and properties are represented by as many material particles, and the problem is solved. These particles are the pangenes.

The pangenes, then, are small, organic particles, invisible to the microscope, formed of an enormous number of chemical molecules and differing from the most complex chemical substances by three properties which are common to all of them and which are characteristic of living matter; they nourish themselves, increase in size, and multiply themselves by division. Beside these three general properties which make living molecules of them, the pangenes possess particular properties depending upon their chemical constitution, differing for each of them, and which are bound to them indissolubly in such a manner that, wherever a pangene finds itself, the elementary property or character special to it will show itself if internal and external conditions permit of this manifestation. Latent or patent, potentially or evidently, the character is always there where is the corresponding pangene. Each cell contains a great number of pangenes in activity, and its characters and properties in sum are the resultant of the elementary characters and properties of the pangenes composing it: just as the anatomical and physiological characters and properties of the living individual are resultant of the anatomical and physiological characters of the cells composing it.

It is necessary to conceive of the cellular protoplasm as formed of innumerable pangenes bathed in a liquid in which are dissolved substances purely chemical: albumen, glucose, salts, etc. Perhaps similar substances penetrate the pangenes themselves, but we do not know this.

The nucleus contains in general all the kinds of pangenes that compose the individual. But these pangenes are there in a sort 
of inactivity, in reserve. in order to be transmitted to the daughter nucleus when the cell divides. They can divide themselves, and it is indeed necessary that this be so in order that the two daughter nuclei can each receive a complete lot of the representative pangenes; but they do not manifest in the nucleus their special properties, which remain in a latent state. There is no exception to this except in the case of those certain pangenes which control the division of the nucleus. These enter into activity at the necessary moment in order to determine the characters of the division and in particular the position of the plane of segmentation.

The cytoplasm is also composed of pangenes; but these pangenes, with the exception of those which come from the cytoplasm of the egg, come from the nucleus. From the nucleus there come, in fact, pangenes which distribute themselves in the cytoplasm and multiply there abundantly. These pangenes are exclusively those of which the cytoplasm has need in order to manifest characters and properties which belong to the cell, and it is by delivering to it such and such pangenes and no others that the nucleus rules the cytoplasm, which would remain inert were it not for this infusion of living and active particles.

There is, then, a great difference between the nucleus and the cytoplasm from the point of view of the pangenetic constitution. Each nucleus contains in general all the pangenes of the individual united undoubtedly into groups more or less considerable, which lie in the chromatic filaments, and these groups, analogous to the gemmules of Darwin's theory, probably form those little grains arranged in rows, which are revealed under a great microscopic magnification of the chromatic threads. But there are one, two, or, at most, a small number of pangenes of each kind; all are inactive save at the moment of division, those which rule this phenomenon; they can multiply themselves but slightly, and in general they do not divide except to replace those which emigrate into the cytoplasm and to furnish at the moment of division to each daughter nucleus the complete lot which it ought to receive. In the cytoplasm, on the contrary, there is but a small number of kinds of pangenes immigrated from the nucleus in the quantity exactly necessary, but there these pangenes are enormously multiplying, so that there is a very great number of each kind, and they are almost always in a state of activity.

B. Hatschek has recently proposed ("Hypothese der Organischen Vererbung," 1905) a new micromeric theory which postulates that Hatschek's the protoplasm is composed of two different kinds of theory. biomolecules; one called ergatules, which function assimilatively, that is, take up food-stuff and excrete waste, but do not 
possess a capacity for growth or self-reproduction; second. the generatules, which have no particular functional work to perform but can grow and reproduce themselves and can carry over this capacity of reproduction to the ergatules, because they can fuse with them or attach themselves to them and thus carry over to them their characteristic peculiarities. These generatules are looked on as the chemical radical of the ergatules, and become therefore the directly determining agents for all peculiarities of the body. The ergatules sit chiefly in the cytoplasm of the cell, while the generatules lie in the cell nucleus, especially in the chromosomes, and therefore render these the bearers of hereditary characteristics.

Thus baldly and wholly incompletely stated these theories of ultimate plasm structure which shall be of a sort to agree with all the varied phenomena of life, and particularly those of heredity, show, unfortunately, only their fantastic face. For as it is precisely in showing how the postulated structure and properties are perfectly consonant with all the known phenomena of life that these theories have their actual interest and strength, a fantastic and improbable face shown as to this robs them of all interest. But, perhaps, it is well that the fantastic aspect of them should be first recognised. For it is only fair to say that the ingenuity and plausibility, the precise and exhaustive development of detail, of some of these theories, are really dangerous to the layman who first happens to read a full and well-stated account of one of them by an enthusiastic upholder. One's eyes become closed to the fact that all the structure and performance that seem so natural, and fit in so exactly with all that we actually know of the phenomena of life, have not been seen. only imagined. One needs an introduction to these theories which insists above all on their wholly hypothetical character. Otherwise one is surprisingly readily hypnotised into accepting one or the other of them as a statement of fact. These general theories are the atomic theories of biology without onetenth the probability of truth or one-tenth the actual acceptance in science that the atomic theory of the chemists has. And even that is beginning to be discarded in modern chemistry. These theories are, as Weismann has said, the outcome of the fact that "the deeper one studies into the phenomena of heredity, the more one is convinced that something of this kind of a condition [of a composition of the fundamental life substance out of ultra-microscopic units bearing a certain spatial relation, and one of attractions and repulsions to each other] must really exist: for it is impossible to explain the observed phenomena in any other way. that is. by any much simpler assumption." But on the other hand a sufficient reason against accepting any one of these highly developed theories. 
of the structure and functional capacity of invisible life-units, is the sagacious one of Delage when he says that simply by the law Delage's of probabilities it will be impossible by pure imagining criticisms. to explain correctly in detail the ultimate structure of protoplasm. Has any one, asks Delage, guessed in advance, with the least truth, structures which the microscope has later been able to reveal to us? Has any one guessed the cross-striation of muscles, the cilia of vibratile epithelium, the prolongations of the nervecells, the make-up of the retina, or the organ of Corti, the chromosomes, the centrosome? Distinctly not. Delage points out that the chemists had a much better chance to lit the truth in supposing atomic structure, for they had a much less complex condition to perceive, and they had approached in their positive knowledge very much nearer the hypothetical element which they adopted.

Le Dantec criticises the micromeric theories of protoplasmic structure by saying that all these theories seek to make mysteries Le Dantec's clearer, complex things simpler, by reducing large criticisms. things to small ones. A man, for example (he says) is composed of 60 trillions of cells and is nevertheless produced by sexual elements of very small size; here is a phenomenon to explain. The micromerist says that the difficulty of this explanation would be less (or at least not so sharply defined!) if one divided the problem into 60 trillions of parts; that is, if one replaced the reproduction of man by 60 trillions of partial reproduction. One has therefore imagined particles infinitely small which are to the cells what the sexual cells are to the man. And this comparison has been, consciously or not, claims Le Dantec, the point of departure of all the systems of particulate representation in the germplasm.

We have simply substituted for a single heredity, continues the critic, 60 trillions of partial heredities, each exactly as mysterious as the first. Thus these 60 trillions of gemmules gathered in the egg and distributed in a precise manner are in reality only a disguising of the homunculus of the ovalists. Perhaps we have no reason to suppose that these gemmules design by their agglomeration this invisible homunculus, but at least it is certain that they are disposed in a manner which is in relation to the form of the man to be determined, since in fact each of them represents not alone a cell of the man, but a cell aith the place it is to occupy.

One sees thus how complex is this system which has for its aim the simplifying of the question of heredity: it is more logical to consider simply the egg as having the power to produce a man than to attribute a power as mysterious to 60 trillions of gemmules to which it is necessary to accord, in addition, a determinative capacity 
which results in conducting each cell to exactly that place which it ought to occupy.

In addition to the theories of an ultimate micromeric structure of protoplasm, certain other recent hypothetical explanations of

Verworn's bio- the special properties of protoplasm should be noted. gen hypothesis. One is the biogen hypothesis of Verworn, the physiologist of Göttingen, one the chemism theory of Le. Dantec, one the physical machine theory of Delage, and another is the general vital principle hypothesis of the neo-Vitalists. Verworn's hypothesis to account for the physiological activities of protoplasm, $i$.e., the special life attributes, as assimilation, disassimilation, growth, irritability, etc., consists in the postulation of a complex chemical compound of unknown structure called biogen, but with the special capacities of an enzyme. This biogen is assumed to be constantly labile, $i$. e., breaking down and rebuilding itself and by this performance acting as a go-between (enzyme or perhaps katalysator) between the atmospheric oxygen brought to the cell by the blood and the oxidisable (food) products (also brought by the blood). Not only can the biogen rebuild itself, but by polymerisation it can grow, that is, increase the size of its molecules by adding sidechains of atoms. 'This, according to Verworn, constitutes cell growth. This growth is not indefinite, as the atoms tend to break away again and thus there is a limit to the size of the biogen molecules. The author only presents his conception of biogen as a good working hypothesis.

Delage has also offered a tentative physico-chemical explanation of certain of the properties of protoplasm. as its movements, its

Delage's ma- nutrition, and even its reducing division, on the basis chine theory. of osmotic effects due to the constant interchange of substance from the outer layers of the cell protoplasm to the inner through fine membranes or special protoplasmic layers which he assumes to enclose each cell part, $i$. e., nucleus, chromosomes, etc. Nutrition, for example, is effected according to Delage, by constant selective osmotic exchanges between the liquid and semi-liquid parts of the cell, the blood-plasm of course constantly bringing food and carrying off excreta to and from the periphery of each cell. Cell division is the result of mutual pulls and pushes, its essential feature always being the actual sundering of parts; but how this mechanical process is guided or controlled as it is, or even initiated, is left unexplained.

Le Dantec holds that life is a chemical phenomenon. "La vie est

Le Dantec's the- un phénomène chimique, c'est-à-dire que les seuls ory of chemism. caractères essentiels par lesquels une action vitale diffère d'une manifestation de l'activité de la matière brute sont rela- 
tifs à des destructions et des constructions d'édifices moléculaires. Cette vérité, toute la biologie nous la prouvera de mille manières; il vaut donc mieux l'énoncer en commençant, de manière à ce qu'elle prenne la première place dans l'esprit de ceux qui se livreront à l'étude des êtres vivants.

"Mais une réaction chimique n'est pas quelque chose d'isolé et ne se produit que dans certaines conditions dont la réalisation peut être liée à des particularités d'ordre physique (chaleur, électricité, lumière, etc.); de plus, elle s'accompagne toujours de phénomènes accessoires qui sortent également du domaine de la chimie (chaleur, mouvement, etc.). Ceci est vrai surtout pour les réactions des matières vivantes, à cause de l'état très spécial de ce qui représente la solution de ces matières dans l'eau. La vie est aquatique, mais les matières vivantes ne se dissolvent pas comme du sel marin" ("Traité de Biologie," pp. 43-44, 1903).

He goes on to discuss, with keen analysis and ingenious but unconvincing synthesis, the various primary conditions and activities of life, explaining each vital phenomenon separately on a basis of chemism. He even proposes a chemical notion of species. Such a chemical species can of course take no primary account of form, but as conditions of chemical identity will usually involve identity of form, the various individuals composing a chemical species will possess a similar or identical form. An author, undertaking what Le Dantec undertakes, must necessarily be a bold thinker and a bold writer. The present author is both. And he is nowhere uninteresting or unsuggestive, but also is he nowhere wholly convincing.

The position of the neo-Vitalists is perhaps best to be taken from that of Driesch, an extremely able present-day biologist, whose Neo-Vitalism, first belief was in a radical mechanical explanation of all life phenomena, and whose brilliant experimental work has furnished many of the examples referred to in all text-books of the modern study of the mechanics of development. But Driesch's present position is an uncompromising belief in the impossibility of explaining life-forms and life-functions on the basis of ever so complex a combination of purely physico-chemical and mechanical conditions and factors. Put positively, neo-Vitalism demands the assumption of an extra-physico-chemical factor (called "psychoid," according to Driesch's nomenclature), which is an attribute of, or essential kind of potentiality pertaining to, organised living substance, and not found in nor influencing inorganic bodies.

Bütschli has well pointed out that neo-Vitalism is really only a return to the old "vital principle" belief, and that we are now, 
and have been ever since our practical giving up of the vital principle notion, making steady progress in the explanation of lifeforms and life-functions on strictly mechanical and physico-chemical grounds. While we have by no means explained all life attributes in this way, Bütschli holds that our progress has been such as to make no demand for the introduction as yet of a new vital principle under a pseudo-scientific guise.

Other neo-Vitalists, of whom G. Wolff is a type, lay chief stress on the inexplicableness of the Zueckmässigkcit in organisms by any of the known biological facts and factors, and see in the determination or very existence of this Zucckmässigkcit the chief revelation of a vital factor, wholly distinct from anything found in the inorganic world. Wolff's argument is clever and suggestive, and brings home to one strongly the indissoluble relationship between living matter and its adaptivity. In its fundamental character life is adaptivity: the indispensable relation between living matter and the rest of nature is the pliability, the adaptiveness of the living matter. "Dic zacekmässige Anpassung ist das, i'as den Organismus zum Organismus macht, was sich uns als das cigcntlichste Wesen des Lebcudigen darstellt. IVir können uns keinen Organismus denken ohne dieses Charakteristikum... Und wir erkennen dass jede Erklärung, welche das Leben voraussetzt, jede postvitale Erklärung der organischen Zweckmässigkeit, in jedem Falle voraussetzt was sie erklären will; wir erkennen dass die Erklärung der Zweckmässigkeit mit der Erklärung des Lebens zusammenfallen muss."

But perhaps there is a difference between the plastic response of protoplasm to the varying conditions of oxygen, food. temperature, etc., about it. so that within certain limits of external versatility it still lives, and that extraordinary specialisation of fitness which we see exhibited by a parasitic Sacculina with relation to its crab host. And believers in natural selection hold that it is exactly one of the chief glories of selection that it does explain this highly specialised fitness. More than that, closer examination of the phenomena of organic Nature reveals many examples of an unfitness, which certainly ought not to exist if there is a special vital principle responsible for fitness throughout the organic kingdom. There is a moth common with us here in California, by name Phryganidia californica, whose larvæ live on the leaves of the oaktrees. Two generations appear each year. The eggs for the first brood of caterpillars are laid in spring by the moths on the leaves of the live-oaks and also of the white-oaks. The larvæ soon hatch, feed through the summer on the leaves, and in September pupate, the moths appearing in October. These moths now proceed to lay 
the eggs for the second generation, which eggs are also deposited on the leaves of both live- and white-oaks. But while the live-oak is an evergreen tree, the white-oak is deciduous, and sheds its leaves soon after these October eggs are laid on them, which means that one-half of this second generation is doomed to die of starvation immediately after hatching. This is repeated regularly each year, and is certainly a distinctly unfit habit in this moth's life economy. Plate refers to a similar instance of Unwreckmässigkcit as follows: "As I once was landing on Santa Maria Island in the Gulf of Aranco, the whole shore swarmed with thousands of giant cuttlefishes (Ommatastrephes gigas) which partly lay dead on the beach and partly were swimming around in the shallow water. These latter instead of trying to get back into deeper water, constantly swam towards the land until a breaker threw them up high and dry. Reflexes and instincts often make mistakes, that is, they result in actions which result in actual harm, and nothing is more mistaken than the declaration that an organism reacts under normal circumstances always in a way to serve the preservation of its life. That organisms under new circumstances or in abnormal condition very often react unfitly, requires no elaboration; every lighthouse against which thousands of birds and insects are killed, the toxicological plienomena, the incomplete regeneration, every clubfoot, and every Wasscrkopf prove this. The countless harmful reactions and incompletenesses in structure make it impossible to speak, in the vitalistic sense, of an inherent Zweckmässigkeit of organisms, of a tendency always to change in the direction of usefulness. An organism is exactly as definitely ruled by chemicophysical laws as every dead body. Let an organism happen in any set of conditions: it has no longer the choice among a useful, a harmful, or an indifferent reaction, but the causal chain determines for a definite direction and this is, as a thousandfold observations show, not a life-preserving one, in other words is not zweckmässig. If now in spite of this organisms have become, in the course of earth-history, even more complex and more capable and have acquired the most wonderful adaptation, there must obtain some regulatory principle in Nature, which we, with Darwin, recognise as actually existing in the struggle for existence and the consequent selection of fit variations. If organisms actually had the capacity to direct their vital activities always toward the side of utility, then the workings of the natural forces would be overcome and Mysticism again be introduced in natural philosophy. Both actual observation and the theoretical basis of natural science give no basis for any hypothesis of the existence in organisms of an immanent capacity for adaptive reactions." 
${ }^{5}$ Weismann, A., "On Germinal Selection as a Source of Definite Variation," trans. McCormack, p. 3, I 896.

${ }^{6}$ I quote from Morgan, "Evolution and Adaptation," pp. 165-166, 1903, the following special protest against the means of escape from Morgan's criti- a tight place which Weismann has taken advantage of cism of Weisin his dilemma: "Thus Weismann has piled up one mann's method hypothesis on another as though he could save the of argument. integrity of the theory of natural selection by adding new speculative matter to it. The most unfortunate feature is that the new speculation is slilfully removed from the field of verification, and invisible germs whose sole functions are those which Weismann's imagination bestows on them, are brought forward as though they could supply the deficiencies of Darwin's theory. This is, indeed, the old method of the philosophisers of nature. An imaginary system has been invented which attempts to explain all difficulties, and if it fails, then new inventions are to be thought of. Thus we see where the theory of the selection of fluctuating germs has led one of the most widely known disciples of the Darwinian theory.

"The worst feature of the situation is not so much that Weismann has advanced new hypotheses unsupported by experimental evidence, but that the speculation is of such a kind that it is, from its very nature, unverifiable, and therefore useless. Weismann is mistaken when he assumes that many zoologists object to his methods because they are largely speculative. The real reason is that the speculation is so often of a kind that cannot be tested by observation or by experiment."

'Roux, W., "Der Kampf der Theile im Organismus." I8\&i.

"Baldwin, J. Mark, "A New Factor in Evolution." Amer. Nat., Vol. XXX, pp. 44I ff., I896; see also the same author's "Develop-

References to ment and Evolution," chap. viii, I902; in the appendiscussions of dices of this book is given a detailed history of the orthoplasy. independent formulation of the theory of "Organic Selection or Orthoplasy," by Baldwin. Osborn. and Morgan.

${ }^{9}$ Osborn, H. F., "A Mode of Evolution requiring neither Natural Selection nor the Inheritance of Acquired Characters," Trans. New York Acad. Sci., pp. I4I-I48. I896; also Science, April 3. I896; also Amer. Nat., Nov., I897. From this last reference I quote the following concise statement of the theory: "This hypothesis as it appears to myself is, briefly, that ontogenic adaptation is of a very profound character; it enables animals and plants to survive very critical changes in their environment. Thus all the individuals of a race are similarly modified over such long periods of time that, very gradually, congenital variations which happen to coincide with 
the ontogenic adaptive modifications are collected and become phylogenic. Thus there would result an apparent but not real transmission of acquired characters."

${ }^{10}$ Morgan, C. L., "Habit and Instinct," pp. 3I2 ff., I896; see also Science, pp. 793 ff., Nov., 1896. In Appendix C of Baldwin's "Development and Evolution," p. 347, 1902, is the following clear statement (in letter to Baldwin) of Morgan's conception of organic selection:

"I. On the Lamarckian hypothesis, racial progress is due to the inheritance of individually acquired modifications of bodily structure, leading to the accommodation of the organism or race to the conditions of its existence.

"2. This proposition is divisible into three: (a) Individual progress is due to fresh modifications of bodily structure in accommodation to the conditions of life. (b) Racial progress is due to the inheritance of such newly acquired modifications. (c) The evolution of species is the result of the cumulative series-

$" a>b+a^{\prime}>b^{\prime}+a^{\prime \prime}>b^{\prime \prime}+a^{\prime \prime \prime}>b^{\prime \prime \prime}$, etc., etc., where a, $a^{\prime}, a^{\prime \prime}, a^{\prime \prime}$ are the acquisitions, and $b, b^{\prime}, b^{\prime \prime}, b^{\prime \prime \prime}$ the cumulative inherited results.

"3. Anti-Lamarckians do not accept (b) and (c). But they accept (a) in terms of survival. No one denies that individual survival is partially due to fresh modifications of bodily structure in accommodation to the conditions of life.

"4. It logically follows from 3 that individual accommodation is a factor in survival which coöperates with adaptation through germinal variation.

"Weismann, following the lead of Roux, interpreted individual modification in terms of intra-selection. He clearly saw the implication given in 4 above. Speaking of 'the well-known instance of the gradual increase in the development of deers' antlers,' he says (Romanes Lecture, 1894. p. 18): 'It is by no means necessary that all the parts concerned should simultaneously adapt themselves by variation of the germ to the increase in size of the antlers; for in each separate individual the necessary adaptation [accommodation] will be temporarily accomplished by intra-selection-by the struggle of parts-under the trophic influence of functional stimulus.'

"6. So far there is no direct relation between specific modifications and specific variations. Individual accommodation, as a factor in survival, affords time (Weismann, op. cit., p. I9) for the occurrence of any variations of an adaptive nature.

"7. My own modest contribution to the further elucidation of the subject is the suggestion (I) that where adaptive variation $v$ is similar in direction to individual modification $m$, the organism 
has an added chance of survival from the coincidence $m+v$; (2) that where the variation is antagonistic in direction to the modification, there is a diminished chance of survival from the opposition $m-v$; and hence (3) that coincident variations will be fostered while opposing variations will be eliminated.

" 8 . If this be so, many of the facts adduced by Lamarckians may be interpreted in terms of the survival and gradual establishment of coincident variations by natural selection under the favourable environing conditions of somatic modifications.

"9. It is clear that there is nothing in this suggestion of a direct relation between specific accommodation and coincident variation which can be antagonistic to the indirect relation indicated above in 6.

"Io. Correlated and coexistent variations would have the same relations to coincident variations as obtain in other cases of natural selection." 


\section{CHAPTER IX.}

OTHER THEORIES OF SPECIES-FORMING AND DESCENT (CONTINUED): AUXILIARY THEORIES (CONTINUED).

Isolation Theories.-The varying importance attributed by different biologists to the theories explaining means Importance of and results of isolation is notable. While by the isolation some the species-forming influence of isolation factor in species- is held to be as effective as selection itself,forming.

some deem it more effective,-others attach but little importance to it, indeed see no effects of consequence. These latter men are likely to be morphologists, cytologists, and laboratory men generally; the former are systematists, students of distribution, and so-called field naturalists. Thus Delage, who gives much attention in his general discussion of the theories of heredity, variation, and species-forming to many purely speculative theories of the ultimate structure and behaviour of protoplasm, and of the mechanism of heredity, dismisses the whole subject of geographic and topographic isolation with a couple of superficial paragraphs, in which he presents a singularly fallacious statement of what the effects of isolation should be. On the other hand the veteran German world-voyager and exploring naturalist, Moritz Wagner, established long ago, on the basis of his observations and deductions, a "law" of species-forming by migration and consequent isolation, which in his mind makes the natural selection theory superfluous. And Henry Seebohm in a discussion of Romanes's ${ }^{1}$ formulation of the principle of physiological selection, says: "So far as is. 
known, no species (of birds) has ever been differentiated without the aid of geographical isolation, though evolution may have gone on to an unknown extent; and, so far as we can judge, geographical isolation must always, sooner or later, be followed by differentiation." And Romanes, himself, conspicuous as the only pupil and disciple of Darwin personally advised and aided by the master himself, and one of the most brilliant upholders and expositors of Darwinism, says:" "Indeed I believe with Mr. Gulick, that in the principle of isolation we have a principle so fundamental and so universal, that even the great principle of natural selection lies less deep and pervades a region of smaller extent. Equalled only in its importance by the two basal principles of heredity and variation, this principle of isolation constitutes the third pillar of a tripod on which is reared the whole superstructure of organic evolution." Thus the most ardent believers in the effects of isolation find it, independent of selection and alone, sufficient to explain speciesforming, while the most ardent neglecters of isolation theories find them too slight to be of any consequence at all. We shall take middle ground and find in isolation a factor of great effectiveness and one wide-spread in its influence in helping to produce the present-day status of the animal kingdom, but yet a factor which shall most fairly be looked on as an auxiliary or helping-theory of natural selection. In fact, to my mind, the proof of the species-establishing effects of isolation, and of the actual existence of isolation (proof of means or modes of isolation), is something much needed by the general natural selection theory for its own support. Selection needs help from isolation. To my mind, also, these means of isolation actually exist, and the resulting isolation is actually a very potent factor in species-forming. The proofs seem to me obvious.

The name isolation fairly well defines the condition that we are to discuss; (the term segregation has also been used 
by some authors to name the same condition). II, in a species, a number of individuals show a certain congenital variation, this variation will probably be lost by What is meant cross-breeding with individuals not having it,
by isolation.

unless the individuals having it are in the majority or unless they become in some way isolated from the others and segregated so that they will breed among themselves. By such isolation and such in-and-in breeding the newly appearing congenital variations might soon become established, and if advantageous be so considerably developed as soon to distinguish as a variety or incipient species the members of the isolated colony. With time a distinct new species might result. Are there means to produce such isolation of groups of individuals belonging to a common species?

The answer to this is certainly an affirmative one. There seem to be, indeed, several means of producing isolation, Varions means and the isolation may be variously named acof effecting iso- cordingly. Undoubtedly the most important of lation.

these kinds of isolation, at least in the light of our present knowledge, is that known as geographical or topographical isolation. Isolation produced in other ways may be called biologic or physiologic or sexual isolation. In the case of geographic or topographic isolation the isolated group or groups of individuals are actually in another region or locality from the rest of the species, this being the result of migration, voluntary or involuntary. In biologic isolation the individuals of the species all inhabit the same territory but become separated into groups by structural or physiological characters which prevent Wagner the miscellaneous inter-breeding. The real founder theory of species- and most insistent upholder of the theory of forming by geo- species-forming by isolation (geographic and topographic isolation), was Moritz Wagner ${ }^{3}$ (I8I3-I887), a traveller and naturalist, whose wanderings and observations brought to him the conviction that while 
natural selection might modify species and even produce continuous evolution it could never differentiate species, that is, produce new species. It could never, in Wagner's belief, produce the actual condition which we know to exist in the present-day and past (now extinct) animal kingdom, this condition being the existence of hosts of distinct, though related, animal species or kinds. Wagner's travels included journeys to North, Central, and South America, West Asia, and North Africa. His first clear enunciation of his theory, in which pronouncement he took definite stand against the claimed capacity of Darwinian selection to produce new species, was in I868. in a paper read in Munich, entitled "Die Darwinische Theorie und das Migrationsgesetz der Organismen." From the time of the appearance of this first paper until within a year or two of his death, Wagner steadily wrote and fought for his theory, but without gaining for it any such wide or authoritative acceptance as he hoped. In a letter dated August 30, I884, Wagner pathetically writes, "Ich sterbe mit der Überzengung, dass man dies wenigstens nach meinem Tode anerkennen wird."

Wagner's theory included not only the characteristics already pointed out as the basis of all theories of the influence of isolation in species-forming, but the assumption that all species of animals have a strong tendency, or are constantly attempting, to "spread out"; that is, have a driving instinct of migration and dispersal. The basis of this tendency is undoubtedly the overcrowding in the immature stages and in times of short food-supply or untoward external conditions of temperature, humidity, etc. This tendency to movement is Wagner's "Migrationsgesetz," and the outcome of it is to bring about conditions of topographic and geographic isolation among all kinds of animals. While in his first papers Wagner looked on his theory as a sort of supporting or auxiliary theory to that of natural selection, he soon began to see in it, calling it now by the name of 
"Separationstheoric," an independent and alternative explanation of species-forming. In 1870 , he wrote: "Um den Unterschied beider Theorien möglichst kurz auszudrücken: nach der Darwin'schen Selectionstheorie züchtet die Natur in Folge des Kampfes ums Dasein rastlos neue typische Formen der Organismen durch Auslese nützlicher Varietäten, gleichviel ob inner- oder ausserhalb des Verbreitungsgebietes der Stammart, und kann diesen Prozess der Bildung einer netien Art nur innerhalb eines sehr langen Zeitranmes vollziehen.

"Nach der Separationstheorie züchtet die Natur nur periodisch neue Formen stets ausserhalb des Wohngebietes der Stammart durch geographische Isolierung und Kolonienbildung, ohne welche bei allen höheren Tieren getrennten Geschlechts keine konstante Varietät oder neue Art entstehen kann. Der Gestaltungsprozess einer neuen Form kann nicht von langer Dauer sein."

Or in still more condensed form $:^{5}$... "Nach der Selektionstheorie ist der Kampf ums Dasein, nach der Separationstheorie die raümliche Absonderung, die nächste zwingende Ursache der Artbildung."

Wagner's latest, most definitive, cleanest cut, single formulation of the Scparationstheoric is that contained in two paragraphs in his essay entitled, "Leopold von Buch und Charles Darwin" (Kosmos, I883). These paragraphs are the following:

"I. Jede dauernde raümliche Absonderung einzelner oder weniger Emigranten von einer Stammart, welche noch im Stadium der Variationsfähigkeit steht, erzwingt auf Grund der Variabilität und der Vererbung eine konstante Differenzierung, indem sie unter Mitwirkung veränderter Lebensbedingungen, die jeden Standortswechsel begleiten, auch die minimalsten individuellen Merkmale der ersten Kolonisten bei blutsverwandter Fortpflanzung fortbildet und befestigt. 
"2. Keine konstante Varietät oder Art entsteht ohne Ausscheidung einzelner oder weniger Individuen von der Stammart und ohne Ansiedelung an einem neuen Standort, weil Massenkreuzung und Gleichheit der Lebensbedingungen in einem zusammenhängenden Wohngebiet immer absorbierend und nivellierend wirken müssen und individuelle Variationen stets wieder in die Stammform zurückdrängen."

Wagner's ${ }^{6}$ long series of interesting papers and addresses are crammed with facts of plant and animal geography, taxonomy and palæontology, and with keen interpretation of these facts, and clear and incisive formulations of his few generalisations.

One of the most ardent present-day upholders of the species-forming potency of geographical isolation is David Starr Jordan, the foremost American student of the classification and distribution of fishes. From a recent paper ${ }^{7}$ I abstract the following brief statements of his beliefs concerning the character and results of the influence of geographical isolation.

"It is now," writes Jordan, "nearly forty years since Moritz Wagner ( I868) first made it clear that geographical

Jordan on isolation. geographic

isolation (räumliche Sonderung) was a factor or condition in the formation of every species, race, or tribe of animal or plant we know on the face of the earth. This conclusion is accepted as almost self-evident by every competent student of species or of the geographical distribution of species. But to those who approach the subject of evolution from some other side the principles set forth by Wagner seem less clear. They have never been confuted, scarcely even attacked, so far as the present writer remembers, but in the literature of evolution of the present day they have been almost universally ignored. Nowadays much of our discussion turns on the question of whether or not minute favourable variations would enable 
their possessors little by little to gain on the parent stock, so that a new species would be established side by side with the old, or on whether a wide fluctuation or mutation would give rise to a new species which would hold its own in competition with its parent. In theory, either of these conditions might exist. In fact, both of them are virtually unknown. In nature a closely related distinct species is not often quite side by side with the old. It is simply next to it, geographically or geologically speaking, and the degree of distinction almost always bears a relation to the importance or the permanence of the barrier separating the supposed new stock from the parent stock.

"A flood of light may be thrown on the theoretical problem of the origin of species by the study of the probable actual origin of species with which we may be familiar, or of which the actual history or the actual ramifications may in some degree be traced."

Dr. Jordan then proceeds to relate and analyse our present actual knowledge of the make-up of certain local faunæ, of the migrations and distribution of certain well-known animal species (especially in the phyla of birds and fishes, in which groups our knowledge of the present status in North America of species and varieties and their distribution is nearly exhaustive), and of the climatic, topographic, and general geographic barriers ${ }^{8}$ which determine this distribution, in a way most convincing to unprejudiced minds. He brings to the support of his own statements of fact and opinion the testimony (contained in personal letters answering direct queries from himself) of many well-known American students of systematic and faunistic zoology. Jordan sums up the results of his display of North American faunal conditions in various paragraphs, from among which the following are quoted:

"In regions broken by few barriers, migration and interbreeding being allowed, we find widely distributed species. 
homogeneous in their character, the members showing individual fluctuation and climatic effects, but remaining uniform in most regards, all representatives slowly changing together in the process of adaptation by natural selection. In regions broken by barriers which isolate groups of individuals we find a great number of related species, though in most cases the same region contains a smaller number of genera or families. In other words, the new species will be formed conditioned on isolation, though these same barriers may shut out altogether forms of life which would invade the open district.

"Given any species in any region, the nearest related species is not likely to be found in the same region nor in a remote region, but in a neighbouring district separated from the first by a barrier of some sort.

"Doubtless wide fluctuations or mutations in every species are more common than we suppose. With free access to the mass of the species, these are lost through interbreeding. Isolate them as in a garden or an enclosure or on an island, and these may be continued and intensified to form new species or races. Any horticulturist will illustrate this.

"In these and in all similar cases we may confidently affirm: The adaptive characters a species may present are due to natural selection or are developed in connection with the demands of competition. The characters, non-adaptive, which chiefly distinguish species do not result from natural selection, but from some form of geographical isolation and the segregation of individuals resulting from it.

"In the animal kingdom, generally, we may say: Whenever a barrier is to some extent traversable, the forms separated by it are liable to cross from one side to the other, thus producing intergradations, or forms more or less intermediate between the one and the other. For every subspecies, where the nature of the variation has been carefully studied, there is always a geographical basis. This 
basis is defined by the presence of some sort of a physical barrier. It is extremely rare to find two subspecies inhabiting or breeding in exactly the same region. When such appears to be the case, there is really some difference in habit or in habitat; the one form lives on the hills, the other in the valleys; the one feeds on one plant, the other on another; the one lives in deep water, the other along the shore. There can be no possible doubt that subspecies are nascent species, and that the accident of intergradation in the one case and not in the other implies no real difference in origins.

"To the general rule that closely allied species do not live together there exist partial exceptions. It may be well to glance at some of these, for no rule is established until its exceptions are brought into harmony with the phenomena which illustrate the rule." (Here Dr. Jordan details the facts of distribution in three cases from among the fishes, which apparently form exceptions to his general rule).

As an example of the effects of an unusual and interesting phase of isolation I may refer to the conditions noted con-

Effects of isolation in the of the Mallophaga, a group of small wingless Mallophaga. insect parasites on birds and mammals. These parasites live for their whole lives among the feathers or hair of their hosts, and while able to run swiftly are unable to fly and thus to migrate freely from bird to bird.

"There are to be noted various results of the influence on the taxonomy of the Mallophaga of the peculiar conditions of their parasitic life. While the uniformity and persistence of the conditions under which the life of the parasites is passed tend to preserve with little change the species types, the peculiar isolation, often pretty complete, of groups of individuals of a parasite species on individual birds of the host species and the consequent close breeding, tend to foster and fix those inevitable slight variations always mani- 
fest in a comparison of offspring and parents, but under normal conditions held in check or lost (unless directly advantageous) by crossing among less closely related individuals. For example, the individuals of a parasite species on a bird of long life and non-gregarious and monogamous habits, like an eagle, live very much the life of an isolated community. There must be many years of in-and-in breeding. It is like island life. The result is certain : the members of this isolated group will soon differ from the specific type in noticeable particulars. On the other hand, the conditions of life on this 'island' are practically identical with the conditions on other similar 'islands'-other eagles-inhabited by other individuals of the same parasite species, so there is no influence working to produce a wide divergence of the members of these various isolated groups of individuals of the same species. Now this isolation of groups of individuals is in some degree an incident of the life of all Mallophaga; in some instances it is considerable; in others, inconsiderable, but taken altogether a condition in the life of the whole order exerting an influence which has the readily recognisable result of creating a great number of small variations within species limits.

"The results, manifest to any student of the group, of these two opposing influences are to render difficult the division of the order into distinct genera on account of the general similarity of structure, and to make difficult the definition of species on account of the many slight variations among the individuals from different bird individuals."

The study of geographic distribution and its infuences on species-forming has not been limited, of course, to living Geographic organisms alone. In fact, the geologic study isolation stadied of distribution and migration of both animals
among past animals. and plants has given us some of our most important facts touching the problem of the influence of isolation on species-transformation. In an interesting paper 
on the "geological study of the migration of marine invertebrates," Smith ${ }^{10}$ has pointed out the general principles and conditions upon which the interpretation of the geographic distribution of the marine invertebrates of the earlier geologic ages must be based.

In closing this consideration of the status of geographic isolation as a factor in species-forming, I should not omit to: Isolation not call attention to the fact, which should be obvian all-suffcient ous enough to any reader, that isolation in itself forming. cannot be the basic and all-sufficient cause for the production of specific differentiation, any more than any selective factor can. The prerequisite in both cases is the occurrence of variation. What are the variations, and how are they produced: these are the fundamental questions in species-forming. Isolation is a tremendously favouring condition but not a primary cause of species-forming. It tends to help along, to hurry up species disintegration, not to. initiate it. It is a biological catalytic agent.

In this present connection the pertinent question is, is the influence of geographical isolation in the cumulation of variation or intra-specific differentiation due to its compelling in-and-in breeding and hence the fostering and cumulation of fortuitous Darwinian variations occurring in the comparatively few individuals of the isolated group, or is there a spur to variation, or even actual production of it along determinate lines, in the new environmental conditions common to all the isolated group but inevitably different from the conditions to which the parent type is exposed? Is there a gradual accumulation of differences between the split-off group and the parent group due to environmental influence plus in-and-in breeding? If we could reply yes to this question, we should have a sufficient explanation of how the isolated group splits rapidly away in many small, and in a few large, characteristics from the parent stock. 
From the foregoing it is obvious that geographical isolation is a proved, effective, and widely applied species-forming factor. So much cannot be said for biologic Biologic isolation. and sexual isolation. ${ }^{11}$ The actual existence of such isolation is not proved by any mass of evidence based on observation, although the theory is by no means pure speculation; nor are the results of such isolation clearly indicated, although a certain amount of observation and experinental evidence can be adduced to show them. The different phases of isolation, not geographic, called by different names, as biologic, physiologic, sexual, and morphologic isolation, all have reference to some sort of segregation of individuals of the same species into groups inside of each of which mating takes place, and among which little or no cross-breeding occurs, because of varying habits, or unusual sexual aversion or attraction, or physiological or morphological variation affecting mating. For example, to take first a sort of combination of geographic and biologic isolation, Plate ${ }^{12}$ points out that there are twelve species of albatrosses in the southern hemisphere, of which nine or ten belong to the Australian zoo-geographical realm and intermingle throughout most of their range. At breeding time, however, these different species become segregated in restricted and separate localities so that mating is always accomplished among different individuals of the same species, although hybridisation could doubtless obtain successfully among these closely related albatross forms. Thus the species characters are kept pure; the species distinct.

An example of pure biological isolation and one within a single species (which is the sort of isolation we are more An example of interested in) might be produced in the followhow biologic isolation might work. ing way. We know of numerous species of butterflies which appear in different seasons of the year in different colour-pattern. This is not a colour 
change in individuals but results from an earlier or later hatching of eggs laid in the autumn or summer before. These eggs may, indeed, be all of one batch or lot, laid by a single female. Some of these eggs hatch in the spring; the butterflies that come from these spring larva are of one colour-pattern; some of the eggs, however, delay hatching until summer; from these larvæ come butterflies of another colour-pattern; some of the eggs even go over until fall before hatching; these latest butterfly individuals may be of a third colour-pattern. The colour-pattern here must have some fixed relation to the time or season of hatching of the eggs; it is not a result of isolation. But the condition well illustrates the actual existence of a biological isolation within a species: the spring butterflies must mate among themselves, the summer individials among themselves, and the fall butterflies among themselves. Within the one species are three biologically isolated groups of individuals restrained from inter-breeding. Suppose the individuals of a bird species show among themselves a tendency to vary in their breeding time; some are ready to breed early, others delay mating. Roughly segregated into two groups, early breeders and late, the individuals of the two groups would obviously tend to breed each inside its own group. Hutton ${ }^{13}$ actually records the occurrence of two varieties of the shore-bird, Estrclata neglecta, in the Kermadec Islands, which live together but breed at different times. A pelagic crustacean living near the shore increases rapidly in numbers; some individuals find themselves able to live on the shore in pools between tide-lines. The pool dwellers breed together: the pelagic individuals breed together; a biologic . isolation-in truth an isolation partly topographic-might soon come to exist. Any variation in habits of life among individuals living in the same locality, which tends to determine that breeding shall be roughly restricted within certain groups produces biologic isolation; such variation might 
be a variance in sexuai maturity, a change in breeding time for that or any other reason, a tendency on the part of certain individuals to live more or less concealed in holes, under stones, etc., changes in food-habits, as the gradual going over of some individuals of a plant-feeding insect species from the old food-plant to a new one, or the tendency within an omnivorous species for groups to restrict themselves to certain specific foods: all such variations might lead to possible biological isolation.

By sexual isolation authors usually refer to the influence of some variation tending to make difficult or impossiSexual ble wholly free and miscellaneous mating or isolation. breeding inside of a species. This variation may be of purely physiological character or may be a structural one: that is, the hindrance to mating may be one of instinctive feeling, a "race-feeling" depending on an antipathy to odour, to age, to appearance, etc., or may be a slight modification of the copulatory organs making such mating difficult, or even a modification of the egg or the spermatozoids making fertilisation difficult. It is a well-known fact that numerous varieties of domesticated animal species rarely breed together, although quite able to, and provided with full opportunity. On the other hand, animals of different species which in Nature rarely or never breed together may, if kept long in confinement, as in zoological gardens, mate $^{14}$ and produce young. In each case there seems to be question of a "race-feeling"; in the first case a sexual aversion keeping apart individuals of the same species, in the second the breaking down of race-feeling that in Nature has sufficed to prevent hybridising. This might be termed physiological isolation, or, indeed, physiological selection, as it has been called, and given much credit for Physiological species-forming by Romanes ${ }^{15}$ and others.
selection. Romanes and Hutton believe that a progressive infertility results in this way (and also by the way referred 
to in the next paragraph) which can soon result in complete infertility, hence specific distinctness on the part of the mutually infertile groups.

Mutual infertility due to morphological variations has been called "mechanical selection" by Karl Jordan,, and may rest on slight variations in germ-cells or Mechanical selection, copulatory structures. Such morphological variations of the reproductive organs have been believed to be shown for butterflies and spiders, while the delicate tropismic responses of the active spermatozoids to the attracting chemical substances in the egg-cells of echinoderms, cœlenterates, molluscs, and fishes have been thought to be conditions in which a slight chemical or physical variation might have a large influence in preventing or insuring fertilisation. Indeed, when one examines comparatively the curiously various complex accessory reproductive organs (claspers, gonapophyses, intromittent organs, etc.) of almost any group of insects, one's first thought is that this variety must practically effectually exclude all possibility of hybridising. But the interesting detailed comparative studies by Snodgrass ${ }^{17}$ of the accessory genitalia in various families of Diptera make this confidence less certain. In the large family Tipulidæ, for example, he finds great complexity and remarkable variety (among the different closely allied species) in this complexity in the genitalia of the males, but almost no variation at all in the corresponding (complementary) parts of the females. "Throughout the entire family the females present one type of structure, of which there is but little modification, and certainly none to correspond with the great varicty of specific differences found in the genitalia of the males." Now while the great variety of the copulatory parts would be extremely significant if shared by both sexes so that only one kind of key could fit one kind of lock, we have the inexplicable condition actually existing of the keys being extremely various and complex, but the locks all 
being so similar and simple that any bent nail is able to pick them.

Seebohm ${ }^{18}$ criticises Romanes's theory of physiological selection, which should better be called physiological Seebohm's isolation, as demanding an almost impossible criticism of physiologic selection. coincidence of conditions to make it work. Formulated as nearly as it can be in a single sentence, Romanes has defined physiological selection as follows: "Wherever, among all the possible variations of the highly variable reproductive system there arises toward any parent form any degree of sterility which does not extend to the varietal form, there a new species must necessarily take its origin." Seebohm points out that this is exactly a condition that can rarely, if ever, occur, for to bring it about we must presuppose :-

"Ist. The special variation of the reproductive organs must occur in two individuals, otherwise the possible ancestor of the new species would leave no descendants.

" 2 d. It must occur at the same time in both.

" 3 d. It must occur at the same place.

" 4 th. The two individuals must be of opposite sexes.

" 5 th. They must each of them possess some other variation, or their progeny would not differ from that of the rest of the species.

"6th. The variation must be the same in both or appear simultaneously in the majority of their children, otherwise it would be swamped by interbreeding within the physiologically isolated family."

Romanes's theory has also been strongly criticised by Wallace ${ }^{19}$ and by Karl Jordan. ${ }^{20}$ Wallace contends that

Other criticisms "no form of infertility or sterility between the of Romanes's individuals of a species can be increased by theory. natural selection unless correlated with some useful variation, while all unfertility not so correlated has a constant tendency to effect its own elimination. But the 
opposite property, fertility, is of vital importance to every species, and gives the offspring of the individuals which possess it, in consequence of their superior numbers, a greater chance of survival in the battle of life. It is, therefore, indirectly under the control of natural selection, which acts both for the self-preservation of fertile and the selfdestruction of unfertile stocks-except always, as correlated above, when they become useful and therefore subject to be increased by natural selection." Jordan maintains that the outcome of physiological selection can be at best only dimorphism, not specific distinctness.

Vernon ${ }^{21}$ has formulated a theory which he calls that of "reproductive divergence," in the following words: "SupVernon's posing that among the members of any species theory of repro-
ductivo diver-

gence.

different characteristic, such as colour, form, or size, are slightly more fertile inter se than less similar individuals, it necessarily follows that in the course of succeeding generations the members of this species will diverge more and more in respect to the characteristic in question, whereby ultimately the original species may be split up into two or more fresh species." As a concrete example, Vernon supposes that in the Lepidopterous Ithania urolina, a certain insect found in the Amazon Valley, small individuals were slightly more fertile with other small individuals than with large individuals, while these were also more fertile inter se; "then it would follow that fewer individuals of intermediate size would be produced, and in course of time the species would be split up into a small and large variety. These varieties would continue to diverge as long as the process of 'reproductive divergence' was acting, till at length they might become differentiated in the two mutually sterile species. Supposing on the other hand this variation in fertility were correlated with slight differences of colour, then in course of time varieties differing in respect of colour 
would be produced; or if it were correlated with both size and colour, varieties differing in respect of both characters might be produced. As a matter of fact, this insect does actually occur as four distinct varieties differing in colour, form, and size, though whether in consequence of the operation of reproductive divergence it is of course impossible to say." But this theory has been strongly criticised by Karl Jordan," who believes himself able to show that reproductive divergence would not work in the way conceived by Vernon, but actually in such a way as to establish an intermediate form.

Karl Pearson ${ }^{23}$ has formulated a theory called "reproductive selection" which he believes to be distinct from both the

Pearson's Romanes and the Vernon theories, and to which theory of repro- he attributes an importance in evolution "equiductive selection, potent to natural selection, if indeed it be not prepotent." The theory is based on correlations which seem to exist between the variation in some particular organ and fertility. From studies of variation of height in 4,000 AngloSaxon families and I,I82 Danish families, Pearson finds that there exists a distinct correlation between fertility and height in the mothers of daughters in these families. The effect of this correlation is to render women less variable and to raise their mean height. The quantities are small, but are sufficient, if unchecked by natural selection, to raise the mean height of women in forty generations by $3 \mathrm{I}-4$ inches. "A factor which would alter stature by about three inches in $\mathrm{I}, 000$ years is clearly capable of producing very considerable results in the long periods during which evolution may be supposed to have been at work."

Of large importance in any consideration of the relations Gulick's im- of isolation to species-forming are the observaportant observa- tions and conclusions of Gulick. Derived origi-

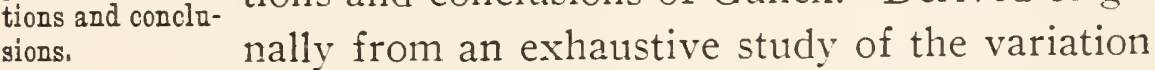
and life-conditions of certain land shells (Achatinellidæ) 
in the Hawaiian Islainds, he formulated, in 1872 , an important principle concerning the species-differentiating effects of indiscriminate isolation. As Romanes ${ }^{24}$ well points out, isolation may not only admit of degrees, that is, may be either total or partial, and, if partial, may occur in numberless grades of efficiency, but it may be either discriminate or indiscriminate. If it be discriminate, the isolation has reference to the resemblance of the separated individuals to one another; if it be indiscriminate, it has no such reference. For example, if a shepherd divides a flock of sheep without regard to their characters, he is isolating one section from the other indiscriminately; but if he places all the white sheep in one field and all the black sheep in another field, he is isolating one section from the other discriminately. Or, if geological subsidence divides a species into two parts, the isolation will be indiscriminate; but if the separation be due to one of the sections developing, for example, a change of instinct determining migration to another area, or occupation of a different habitat on the same area, then the isolation will be discriminate, so far as the resemblance of instinct is concerned. Discriminate isolation has been called by Gulick segregate breeding, and indiscriminate isolation separate breeding.

Now the effectiveness of discriminate isolation or segregate breeding, however effected, to produce species-differentiation is of course obvious. In fact, as Romanes points. out, it is only when assisted by some form of discriminate isolation which determines the exclusive breeding of like with like, that heredity can make in favour of change of type or lead to what we understand by organic evolution. But what about indiscriminate isolation? Does it not seem, at first sight at least, that this kind of isolation must count for nothing in the process of evolution? Is it not apparently self-evident that the farmer who separated his stock into two or more parts indiscriminately, would not effect any more 
change in his stock than if he had left them all to breed together?

"Well," says Romanes, "although at first sight this seems self-evident, it is in fact untrue. For, unless the individuals which are indiscriminately isolated happen to be a very large number, sooner or later their progeny will come to differ from that of the parent type, or unisolated portion of the previous stock. And, of course, as soon as this change of type begins, the isolation ceases to be indiscriminate: the previous apogamy [indiscriminate isolation] has been converted into homogamy [discriminate isolation], with the usual result of causing a divergence of type. The reason why progeny of an indiscriminately isolated section of an originally uniform stock-c. g., of a species-will eventually deviate from the original type is, to quote Mr. Gulick, ${ }^{25}$ as follows: "No two portions of a species possess exactly the same average character, and, therefore, the initial differences are for ever reacting on the environment and on each other in such a way as to ensure increasing divergence as long as the individuals of the two groups are kept from intergenerating."

Gulick was led to his recognition of the principle in question, not by any deductive reasoning from general principles,

Golick's stud. ies of Hawaiian but by his own particular and detailed observaland-snails. tions of the land mollusca of the Sandwich Islands. Here there is an immense number of varieties belonging to several genera; but every variety is restricted, not merely to the same island, but actually to the same valley. Moreover, on tracing this fauna from valley to valley, it is apparent that a slight variation in the occupants of valley 2 as compared with those of the adjacent valley $\mathrm{I}$, becomes more pronounced in the next valley 3 , still more so in 4 , etc., etc. Thus it was possible, as Mr. Gulick says, roughly to estimate the amount of divergence between the occupants of any 
two given valleys by measuring the number of miles between them.

On the basis of his detailed observations, Gulick ${ }^{28}$ has proposed the following three general propositions as to the relations of isolation to species-forming:

"I. A species exposed to different conditions in the different parts of the area over which it is distributed, is not represented by divergent forms when free inter-breeding exists between the inhabitants of the different districts. In other words, diversity of natural selection without separation does not produce divergent evolution.

"2. We find many cases in which areas, corresponding in the character of the environment, but separated from each other by important barriers, are the homes of divergent forms of the same or allied species.

"3. In cases where the separation has been long continued, and the external conditions are the most diverse in points that involve diversity of adaptation, there we find the most decided divergences in the organic forms. That is, where separation and divergent selection have long acted, the results are found to be the greatest.

"The first and second of these propositions will probably be disputed by few, if by any. The proof of the second is found wherever a set of closely allied organisms is so distributed over territory that each species and variety occilpies its own narrow district, within which it is shut by barriers that restrain its distribution, while each species of the environing types is distributed over the whole territory. The distribution of terrestrial molluses on the Sandwich Islands presents a great body of facts of this kind."

Finally in a recent exhaustive discussion of the subject ${ }^{27}$ of the relation of isolation to evolution Gulick declares that "the whole process of bionomic evolution, whether progressive or retrogressive, whether increasingly ramified and divergent, or increasingly convergent through amalgama- 
tion, is a process by which the limitations of segregate breeding are either set up and established or cast down and obliterated."

\section{APPENDIX.}

${ }^{1}$ Seebohm. Henry, "Physiological Selection," p. I2, I 886.

"Romanes, G. J., "Darwin and After Darwin," Vol. III. p. I, I897.

${ }^{3}$ Wagner, Moritz, "Die Entstehung der Arten durch Räumliche

References to Sonderung," I889. This book is made up of the discussions of collected papers of Wagner, printed originally in the isolation, time from I868-I886, mostly in the journal Kosmos.

${ }^{4}$ Wagner. Moritz, "Über den Einfluss der geographischen Isolierung und Kolonienbildung auf die morphologischen Veränderungen der Organismen," July, I870.

"Wagner, Moritz, "Über die Entstehung der Arten durch Absonderung," Kosmos, Is8o.

${ }^{6}$ Haacke in his "Grundriss der Entwicklungsmechanik," I897, gives. on pp. 335-336, an excellent summary statement of Wagner's position, as follows:

"Wenn wir eine Tierart bis an die Grenze ihres Verbreitungsgebietes verfolgen und diese Grenze überschreiten, so stossen wir

Haacke's sum- gewöhnlich sehr bald, und oft schon, ehe wir die mary of Wag- Verbreitungsgrenze der betreffenden Art erreicht ner's theory. haben, auf eine andere, und zwar auf eine mit der ersteren nächstverwandte Tierart, die aber ein anderes Verbreitungsareal inne hat. Gehen wir auch über das Gebiet dieser letzteren Art hinaus, so können wir auf eine dritte. vierte und fünfte Art stossen, von denen jede den beiden ersten verwandt sein kann und ein besonderes Verbreitungsgebiet bewohnt. Im allgemeinen können wir den Satz aufstellen, dass es keine zwei nächstverwandten Tierarten giebt, deren Verbreitungsgebiete sich vollkommen decken. Vielfach kann der Fall festgestellt werden, dass die Verbreitungsgebiete zweier nächstverwandter Tierarten sich teilweise decken; aber eine vollkommene Deckung ist noch in keinem Fall bei zwei oder mehr nächstverwandten Tierarten festgestellt worden. Es kann auch vorkommen, dass das Verbreitungsgebiet der einen Art vollständig innerhalb desjenigen der andern Art liegt, das also, soweit der Wohnkreis der ersten Art reicht, ein Zusammenfallen mit dem Verbreitungsgebiet der zweiten Art stattfindet; aber in solchen Fällen dehnt sich eben die Heimat der einen Art über die der zweiten aus, so dass von Kongruenz der beiderseitigen Wohngebiete nicht die Rede sein kann. Nächtsverwandte Tierarten sind 
ketten- oder, besser gesagt, netzförmig über die Erde verbreitet. Wie die Maschen eines Netzes reihen sich die Wohngebiete der Arten einer Gattung aneinander, und wenn auch, wie schon hervorgehoben, mancherlei teilweise Deckungen vorkommen, so hat sich noch in allen Fällen, wo man die Grenzen der Verbreitungsgebiete nächstverwandter Arten festgestellt hat, die Thatsache ergeben, dass keine vollkommene Deckung stattfindet. Aus dieser Thatsache können wir den Schluss ziehen, dass in einem und demselben Gebiete, soweit wenigstens alle Individuen unter denselben Verhältnissen leben, aus einer Art nicht zwei oder mehr neue Arten werden können. Wagner meinte zuerst, dass hierbei die Möglichkeit einer allseitigen Kreuzung, wie sie nach ihm innerhalb eines und desselben Wohnkreises einer Art möglich sein soll, eine grosse Rolle spielt. Er hat übrigens seine Ansichten im Laufe der Zeit geändert und es ist deshalb notwendig, auf die Entwickelungsgeschichte seiner Ideen etwas näher einzugehen. Ursprünglich suchte Wagner seine Theorie mit der Darwin'schen zu vereinigen. Nach der letzteren entsteht eine neue Art dadurch aus einer vorhandenen, dass die Lebensbeeinflussungen andere werden, und dass nunmehr diejenigen Individuen seitens der züchtenden Natur ausgewählt werden, die den neuen Lebensbeeinflussungen am besten entsprechen. Wagner nahm nun an, dass dies zunächst nur einzelne Individuen sein können, und dass nicht bloss sie, sondern noch eine grosse Anzahl anderer leben bleiben. so dass nicht allein die Möglichkeit, sondern auch die hohe Wahrscheinlichkeit gegeben ist, dass die den neuen Lebensbeeinflussungen am besten entsprechenden, von den übrigen Individuen der betreffenden Organismenart abweichenden Vertreter der letzteren sich mit denjenigen geschlechtlich mischen, die nicht in zweckentsprechender Weise abgeändert sind, wodurch die neuen Errungenschaften wieder verloren gehen sollten. Wagner suchte also den Nachweis zu führen, dass die Darwinische Selektionstheorie nicht geeignet sei, eine Züchtung neuer Tier- und Pflanzenarten ohne eine Hülfslehre, die er in seiner 'Migrationstheorie' gefunden zu haben glaubte, nachzuweisen. Er meinte, dass die vorteilhaft abgeänderten Individuen. wenn nicht in allen, so doch in manchen Fällen auswandern würden in eine Gegend, wo die Art, der sie angehören, nicht vertreten, wo also die Möglichkeit einer Kreuzung mit unabgeänderten Individuen ausgeschlossen ist. Später hat Wagner seine Migrationstheorie durch die der Separation oder der räumlichen Sonderung ersetzt, indem er zugleich die Verquickung seiner Anschauungen mit denen des Darwinismus zurücknahm. Nach Wagners Separationstheorie bilden sich neue Arten dadurch, dass. auf die eine oder andere Weise etliche Individuen einer Art in ein 
Gebiet gelangen, das vorher nicht von dieser Art bewohnt war. Die Entstehung neuer Arten erklärt sich dann nach Wagner dadurch, dass, da die Individuen einer Art ja alle mehr oder minder voneinander abweichen, die wenigen Gründer der neuen Art ihre Besonderheiten bewahren und nicht durch Kreuzung mit anderen Individuen wieder einbüssen würden. Die Anpassung lässt Wagner aber im Sinne Lamarcks zustande kommen, und neben Einrichtungen, die den Organismen von Nutzen sind, erkennt er andere an, die lediglich der Ausdruck eigentümlicher Struktur smd. Die klimatischen Verhältnisse sind nach Wagner von sehr untergeordneter, die Verhinderung der Kreuzung ist von ausschlaggebender Bedeutung. Wagner huldigte ferner der Anschaung, dass die weisse Farbe der Polar- und die gelbe der Wüstentiere dadurch zustande gekommen ist, dass entsprechend gefärbte Individuen von Arten, die andere Gegenden bewohnten, nach den Polarländern und den Wüsten auswanderten."

'Jordan. D. S.. "The Origin of Species through Isolation," Science, N. S., Vol. XXII, pp. 545-562, I905.

${ }^{8}$ An excellent example of the careful study of the relation of $a$. group of recognised varieties, or sub-species of a species, to the Grinnell's study climatic differences of their various geographic of geographic ranges, is presented by Jos. Grinnell in "The Origin: differences in the and Distribution of the Chestnut-backed Chickadee,"chickadee. Auk, Vol. II, pp. 364-382, Ig04. I quote from this. paper the following:

"The chestnut-backed chickadee (Parus rufcscens) is a boreal. species of peculiarly limited distribution. It is almost exclusively confined to the humid Pacific Coast region of North America, within which it is the most abundant, and in many places the only member of the genus Parus present. We find it characteristically at home within the densest coniferous forests, or along their edges, where there is much shade and an even temperature.

"The range of the chestnut-backed chickadee is nearly two. thousand miles long, north and south, extending from a little north of Sitka, Alaska, to some forty miles below Monterey, California.. But its width is very narrow, only within the confines of Oregon and Washington exceeding one hundred miles, and elsewhere usually much less, save for one or two isolated interior colonies to be mentioned later.

"The influences determining this queer-shaped distribution area may be safely assumed to be atmospheric humidity, with associated floral conditions. For this habitat coincides quite accurately with the narrow coastal belt of excessive cloudy weather and rainfall.

"The specific character distinguishing Parus rufescens from all. 
other American chickadees is the colour of the back, which is an intense rusty-brown, approaching chestnut. It is of common note that the most evident effects of similar climatic conditions on other animals is a corresponding intensification of browns, especially dorsally. We may, therefore, consider the chestnut-backed chickadee, as indicated by its chief specific character, to be a product exclusively of the peculiar isohumic area to which we find it confined.

"Parus rufescens, from Sitka to Monterey, has a chestnut-coloured back. And from Sitka to Point Arena, between which we find the extremest humidity, another conspicuous character is uniform,the colour of the sides, which are also deep rusty brown. But from Point Arena south to San Francisco Bay (Marin District), these lateral-brown areas suddenly weaken to pale-rusty; while from San Francisco south past Monterey (Santa Cruz District), adult birds have the sides pure smoke-gray without a trace of rusty.

"The species thus presents geographic variation within itself, and three distinguishable forms have been named, respectively, the chestnut-sided chickadee (Parus rufescens rufescens), the Marin chickadee (Parus rufescens neglectus), and the Santa Cruz chickadee (Parus rufesccns barlowi). But all three sub-species are unmistakably the chestnut-backed chickadee (Parus rufescens)....

"As has already been asserted, Parus rufescens doubtless arose as a geographical race of Parus pre-hudsonicus [the hypothetical common ancestor of the present species, Parus hudsonicus, occupying the interior of Alaska and British Columbia east to Labrador and Nova Scotia, and Parus rufcscens]. It is now called a 'species' because intermediates have dropped out; in other words, the divarication is now wholly complete and there are two separate twigs. The area of intermediate faunal conditions between the humid coast belt and the arid interior region of British Columbia and Alaska is very narrow, consisting. in places personally traversed by me, of but a few miles over a mountain ridge. This very narrowness of the area of faunal mergence probably accounts for the lack of intermediates at the present day between hudsonicus and rufescens.

"In the case of Parus rufescens and Parus hudsonicus, there seems to be now a narrow hiatus between the two. At least I can find no record of the two species having been found in the same locality. The narrowness of the region of intermediate faunal conditions may therefore be considered as the reason why we do not find connecting links between hudsonicus and rufcscens at the present time. For the amount of difference between these two chickadees does not strike me as any greater than, for instance, 
between Melospiza cinerea montana and Melospiza cinerea rufina, between which there is continuous distribution and free interosculation. But we cannot expect any two species of birds or other animals to present the same degrees of differentiation in the same length of time or under the same conditions, much less under different conditions. For in no two animals is the physical organisation, in all respects, exactly the same.

"In a given aggregation of individuals constituting a new colony, a certain amount of time is necessary for the set of environmental factors to become operative in bringing about new inheritable characters to a degree perceptible to us. Then the inherited effects of invasion and cross-breeding from season to season from the adjacent parent centre of differentiation will be evidenced less and less, as time elapses, as the distance from this centre increases. The offspring of successively further removed unions will, of course, inherit to a less and less degree the distinctive characters of the ancestral stock on one side and more and more of the incipient ones on the other.

"If, now, the distance is great enough to permit of the time required for adaptive manifestations to become innate, then we would find new characters making their appearance distally nearest the new centre of differentiation. If the distance were too short we would not find new characters showing themselves because they would be constantly crowded down by the influx of the old. The time factor may. therefore, be reduced by the intervention of an impassable barrier. As an instance, we find three (and there are probably two other) instular forms of the song sparrow within a limited distance among the Santa Barbara Islands, while through the same distance on the adjacent mainland there is but one. Or, in the case of continuous distribution. the time element may be comparatively lessened by the great distance between the range limits. and it may be still further decreased as these limits lie in faunal areas of more emphatically different nature. The horned larks, as well as song sparrows, furnish us several good examples of the latter two rules.

"It is isolation, either by barriers or by sufficient distance to more than counterbalance inheritance from the opposite type. that seems to me to be the absolutely essential condition for the differentiation of two species, at least in birds.

"A strong argument in support of this conviction is that we never find two 'sub-species' breeding in the same faunal area, and no two closely similar species, except as can be plainly accounted for by the invasion of one of them from a separate centre of differentiation in an adjacent faunal area. An appropriate instance 
in illustration of the latter is the occurrence together. in the Siskiyou Mountains of northern California, of the brown Parus rufescens of the wet coastal fauna and the gray Parus gambcli of the arid Sierran fauna. (See Anderson and Grinnell, Proc. Ac. Nat. Sc., Phila., 1903, p. 13.) The Siskiyou Mountains occupy a line of mergence between the two faunæ, and the two respectively representative chickadees have evidently extended their ranges toward each other until now over this one small area they occupy common ground. Several parallel cases could be cited; their significance seems obvious.

"We come now to consider the origin of the races of Parus rufesccus. In a species of recent arrival into a new region (by invasion from a neighbouring faunal area), as it adapts itself better and better to its new surroundings, granted the absence of closelyrelated or sharply-competing forms, its numbers will rapidly increase. This means that there will be increased competition within the species itself, on account of limited food supply. The alternative results are either starvation for less vigorous individuals during recurring seasons of unusual food scarcity, or dissemination over a large area. In a way the first might be considered as beneficial in the long run, as doubtless leading to the elimination of the weaker; such a process evidently does take place to a greater or less degree all the time, and is important for the betterment of the race. But as a matter of observation Nature first resorts to all sorts of devices to ensure the spreading of individuals over all inhabitable regions; in other words, the extremest intra-competition does not ensue until after further dissemination is impossible. In birds we find a trait evidently developed on purpose to bring about scattering of individuals. This is the autumnal 'mad impulse' which occurs just after the complete annual moult, when both birds-of-the-year and adults are in the best physical condition, and just before the stress of winter food shortage. Even in the most sedentary of birds, in which no other trace of a migratory instinct is discernible, this fall season of unrest is plainly in evidence. I may suggest, not unreasonably, that autumnal migration may have had its origin in such a trait as this, the return movement in the spring becoming a necessary sequence. (See Loomis, Proc. Cal. Acad. Sc., 3d series, Zoölogy, II, Dec., 1900, 352.) It is a matter of abundant observation that autumn is the season when we find the most unlooked-for stragglers far out of their normal range and when sober, stay-at-home birds, like Pipilo crissalis and the chickadees, wander far from the native haunts where they so closely confine themselves the rest of the year. It is also the experience of collectors that the greatest number of these stragglers 
are birds-of-the-year, which thus, obeying the 'mad impulse,' are led away from their birthplace into new country, where they may take up their permanent abode, and be less likely to compete with their parents or others of their kind. Then, too, cross-breeding of distinctly related individuals is more likely. The records of the Santa Cruz chickadee outside of its regular breeding range, are all of August to October dates (Haywards, Gilroy, San José, etc.).

"Thus. as above indicated, by the occupancy of new territory the number of individuals which can be supported will correspondingly grow. Hence a vigorous colony will spread out along lines of least resistance, being hindered by slight faunal changes, but completely checked only by topographic or abrupt climatic barriers. Parus hudsonicus and its near relative Parus rufcscens are boreal species, the former inhabiting the Hudsonian Zone and the latter a certain portion of the Canadian. It seems reasonable to suppose that rufcscens differentiated in the northern part of the humid coast belt, which has been called the Sitkan District. This is a faunal subdivision of the Canadian Zone, and its northern part approximates more closely Hudsonian conditions than southerly. Granting that the early centre of differentiation and distribrition of Parus pro-hudsonicus rufescons was in the northern part of the Sitkan District, then the route of emigration would be confined to the narrow southward extension of that faunal area. The habitat of Parus rufcscens thus gradually acquired the long north and south linear appearance, as shown at this day. But when the pioneer invaders at the south reached the vicinity of Point Arena, they met with somewhat changed temperature and consequent floral conditions. but not so abrupt as to constitute a permanent barrier. Doubtless the progress of invasion was retarded until adaptive modifications evolved, which correlatively. allowed of further invasion, until the abrupt limits of the Santa Cruz District were reached.

"San Francisco Bay and the Golden Gate seem to now form a pretty effectual barrier between neglectus on the north and barloui on the south. At least. among the large number of skins examined by me with this point in view, I can find none from one side that can be confidently determined as being identical with the race on the other. Neither chickadee has been found east of the bay, nor anywhere nearly so far from the coast belt, except for one record of a specimen taken in the fall at Haywards. This has been reëxamined and proved to be barlorsi, as was to be expected from its contiguity. However, the Golden Gate is so narrow that an occasional crossing may take place. This was more probable formerly, when the redwood timber grew up to the Gate on both sides. 
Heermann, in I853, recorded the species from 'San Francisco.' But now. I think, the bird is unknown for several miles on either side of the Gate. Doubtless this barrier accounts in part for the origin of the distinct form barlozvi within so short a distance. . .

"As has become a generally accepted idea, the young plumages of birds. if different at all from those of the adults, present a generalised type of coloration; or, to express it in another way, the young more nearly resemble recent ancestral conditions. The familiar examples of the spotted, thrush-like plumage of the young robin and the streaked, sparrow-like plumage of young towhees and juncos are cases in point. Accepting this phylogenetic significance of ontogeny, we find the chickadees giving some interesting illustrations.

"Although the adult of barlowi has the sides pure smoke-gray, the juvenal plumage possesses pale-rusty sides. This points towards a rusty-sided ancestor like neglcctus. This also agrees perfectly with the distributional evidence of origin. The adult of neglectus has pale-rusty sides; the young also has rusty sides, but somewhat darker than in the corresponding age of barlowi, and moreover is more nearly like the juvenal plumage of rufescens. But the sides in adult rufescens are deep brown, almost chestnut, while the young has much paler, merely dark-rusty sides. And what is most significant is that the young of rufescens and hudsonicus are much nearer alike than are the adults, the former having only very slightly darker rusty on the flanks. The young of hudsonicus in respect to intensity of browns almost exactly equal the adults of the same species, showing that the present coloration is of very long standing, and offering further evidence that hudson$i c u s$ is nearest the common stock form of all the chickadees under consideration. Juvenal characters, resembling ancestral conditions, lag behind the newer acquired adult characters.

"To repeat: The young of barlowi has the sides paler rusty than neglectus, neglectus slightly paler than rufcscens, but rufescens has the sides slightly more rusty than hudsonicus, a sequence which accords well with the present theories of origin."

${ }^{9}$ Kellogg, V. L., "New Mallophaga, I," Contrib. to Biol. from the Hopkins Seaside Laboratory of Leland Stanford Jr. University, I896.

${ }^{10}$ Smith, Jas. P., "Studies for Students: Geological Study of Migration of Marine Invertebrates," Journal of Geology, Vol. III, pp. 48I-495, I 895 .

${ }^{11}$ Any selective breeding or segregation produced by other means than the separation of groups of individuals by actual topographic, or geographic barriers may be called biologic or sexual isolation. 
${ }^{12}$ Plate, L., "Über die Bedeutung des Darwin'schen Selectionsprinzip," p. 193, I903.

${ }^{13}$ Hutton, F. W.. "The Place of Isolation in Or-

Further refer- ganic Evolution," Nat. Science, Vol. XI, pp. 240-246, ences to discussions of isolation, I897.

${ }^{14}$ The not uncommon mating, in zoological gardens, of lions and tigers, with the production of healthy cubs, is a case in point.

${ }^{15}$ This principle, strongly advocated by Romanes, seems first to have been presented by Eimer in connection with his theory of orthogenetic evolution. At least it enters into the make-up of the Eimerian theory. See account of Eimer's theory in chapter $\mathrm{x}$ of this book.

${ }^{16}$ Jordan, Karl, "Mechanische Selection," I896; see also Petersen, Wilh., "Entstehung der Arten durch Physiologische Isolirung," Biol. Contralbl., Vol. XXII, pp. 468 ff., I902; also Vol. XXIV, pp. 423-43I, 467-473. I904. Author describes cases of marked difference in reproductive organs (includes primary and accessory parts) of closely allied species of Lepidoptera.

${ }^{17}$ Snodgrass, R. E., "The Terminal Abdominal Segments of Female Tipulidx," Jour. N. Y. Ent. Soc., Vol. XI. pp. I77-I83, I903; "The Hypopygium of the Tipulidæ." Trans. Amcr. Ent. Soc., Vol. XXX, pp. I79-235. 1904; "The Hypopygium of the Dolichopodidx," Proc. Cal. Acad. Sci., Ser. 3, Zool., Vol. III, pp. 273-285, I904.

${ }^{18}$ Seebohm, H., "Physiological Selection," I 886.

${ }^{19}$ Wallace, A. R.. "Darwinism." p. I80, I89I.

${ }^{20}$ Jordan, Karl, "Novitates Zoologicæ," pp. 426 ff., I896.

${ }^{21}$ Vernon, H. N., "Reproductive Divergence: An Additional Factor in Evolution," Natural Science, Vol. XI. pp. I8I-I89, I897.

${ }^{22}$ Jordan, Karl, "Reproductive Divergence: A Factor in Evolution?" Natural Scicncc, Vol. II, pp. 317-320, I897.

${ }^{23}$ Pearson, Karl, "Reproductive Selection," Natural Scicnce, Vol. VIII, pp. 321-325, I896.

${ }^{24}$ Romanes. G. J., "Isolation in Organic Evolution," Monist, Vol. VIII, pp. 19-38, I897.

${ }^{25}$ Gulick, J. T., "Divergent Evolution through Cumulative Segregation," Jour. Limn. Soc., Zool., Vol. XX, pp. I89-274. 1888.

${ }^{26}$ Gulick, J. 'T., Jour. Linn. Soc., Zool., Vol. XX, pp. 202-2I I, 1888 .

${ }^{27}$ Gulick, J. T., "Evolution, Racial and Habitudinal," Pub. No. 25. Carnegie Institution of Washington, 1905. In this large paper are to be found references to all of the author's important papers. Some of these papers are reprinted (some completely, some in part) in this monograph. 


\section{CHAPTER X.}

\section{OTHER THEORIES OF SPECIES-FORMING AND}

DESCENT (CONTINUED) : THEORIES ALTERNATIVE TO SELECTION.

We come now to the brief consideration of three general theories, or groups of theories, which are offered more as alternative or substitutionary theories for natural selection than as auxiliary or supporting theories. These groups of theories are the Lamarckian one, based on the inheritance of characters acquired individually (ontogenetically) during the lifetime of the organism due to the effects of use and disuse and functional stimuli; the general conception of orthogenesis variously provided for by Nägeli, Eimer, Jaeckel (metakinesis), and others, and finally the theory of heterogenesis, suggested by von Kölliker, definitely formulated by Korschinsky, and most recently, and importantly, developed by de Vries. Few biologists would hold any of these theories to be exclusively alternative with natural selection; de Vries himself would restrict natural selection but little in its large and effective control or determination of the general course of descent. But all of these theories offer distinctly substitutional methods of species-forming, and one of them includes certainly the most favoured explanation, next to selection, of adaptation, while the authors or later up-holders of some of them actually deny any constructive, that is, adaptational, species-forming or descentcontrolling, influence of natural selection.

The Lamarckian Theory.-It is a great presumption to attempt to offer in so small a book as this any exposition of a theory so long known and elaborately developed as the ex- 
planation of adaptation and species-forming known as Lamarckism. Lamarck ${ }^{1}$ proposed his theory at

Lamarckism.

a time most inopportune; it met with no general acceptance, but in later years, post-Darwinian years, fair-minded biologists have turned back to the books and papers of this pioneer French exponent of the evolution principle and have given his theory the careful attention and scrutiny it deserves-but which it failed to get from Lamarck's contemporaries. This reëxamination of the Lamarckian theory or theories has given rise to most radically divergent opinion and belief concerning its worth: many biologists account it of great value, others reject it practically in toto. But this acceptance or rejection depends almost entirely on one's attitude toward a single fundamental part of it, namely, the assumption that variations, modifications, or characteristics acquired during the lifetime of an individual, these modifications usually being due to use, disuse, or other functional stimulation of organs and parts, can be transmitted by this individual to its offspring. If such newly-acquired, non-inherited characteristics can be transmitted in full and in detail, or even approximately so, from the parent to the young, then Lamarckism obviously offers the simplest of all the explanations so far presented, of nearly all active and of many passive adaptations. If such characters cannot be so transmitted, then Lamarckism, as plausible, as reasonable, as simple and effective as it seems to be, is practically without validity.

Now this matter of the inheritance of acquired characters, apparently easily susceptible of definite proof or refuta-

The inheritance tion by observation and experiment, has been of acquired char- for years and is to-diay one of the burning probacters. lems of biology. There is no general agreement about it, no consensus of authority even. Just at present the weight of evidence inclines strongly against such an inheritance, chiefly because of Weismann's successfully 
destructive criticism of about all the evidence of observation which has been offered in behalf of it. And yet just at the present time do biologists recognise more keenly than ever the need and relief the actuality of such inheritance would give them in their attempts to solve the great problems of adaptation and species-forming? I cannot undertake to say whether more reputable biologists disbelieve in than believe in the existence of such inheritance, but it is obvious that the disbelievers have the present prestige of apparent victory: they call for convincing evidence of such inheritance, and it is not produced. On the other hand, there are many reputable, thoughtful, honest, actively working biologists and palæontologists (particularly many palæontologists in proportion to the total number of palæontological students) who say, although not loudly and even a bit shamefacedly, perhaps, that they must believe in the possibility and the actuality of this inheritance; there is no getting forward without it.

In taking up our brief exposition of Lamarckism, let me say first that only in post-Darwinian years has Lamarckism been put so strongly in contrast with Darwinism as it has. Darwin himself included part of Lamarckism as a minor factor or influence in his explanation of adaptation and species-forming, and Plate, in the recent most notable critical discussion of Darwinism, takes nearly exactly the old ground of Darwin, namely, an acceptance of the inheritance, in some degree and under some conditions, of acquired characters, and the consequent possibility of a certain amount of Lamarckian orthogenesis, $i$. e., an orthogenesis due to the inheritance of the results of use, disuse, and functional stimuli. It is only neo-Darwinism (of Weismann, Wallace, and others) and neo-Lamarckism (of Spencer, Packard, and others) that are so radically opposed, so mutually exclusive.

That an animal in its lifetime, and especially during its. 
immature life can effect very considerable changes in someThe concep- of its body-parts by special use or disuse of tion of evolution these parts, or that certain parts may be modi-
according to Lamarok. fied through the influence of external stimuli, is familiar knowledge. Let one recall the increase of the blacksmith's biceps and inversely the degeneration of unused muscles, and the thickening or callousing of palms or other parts of the skin exposed to repeated rough contact. Bones have ridges developed on them by repeated musclepulls, the hands and eyes can be trained to special functional skill which involves important although perhaps slight physical changes, the heart and lungs can be enlarged by special use; in short, almost any of the organs of the body, which are actively used, can be modified either by unusual or extra use, or by unusual lack of use. Now this use is, in Nature, almost always of the character of a better aiding in successful living; that is, it is adaptive use. Animals often chased by enemies become fleeter by practice; animals that must dig for roots or climb trees for leaves and fruits, or dive for fishes, or leap over obstacles, come by repeated digging, climbing, diving, or leaping to do these things better; the muscles and tendons and bones work together better and better, become physically modified in accordance with these endeavours. If such betterment of organs and their functions. acquired by individuals could be inherited by their young, it is obvious that general adaptations of this sort could be rapidly developed in the course of generations, and new species, new, that is, because of the adaptive changes thus effected, be formed. This is the essential thought in Lamarck's theory of the method of adaptation and speciesforming. In almost all criticisms of Lamarckism one reads much contemptuous reference to the expected results of the organism's "willing" to vary or change in this or that direction. As a matter of fact the critics of Lamarckism give that rather absurd feature of alleged Lamarckism mucin 
more conspicuousness than Lamarck did. He did, indeed, make some reference to the possible volitional effort of the organism to change along certain desirable lines, but it is evident that Lamarck had more in mind the animal's desires and needs to stretch up higher for leaves or to dig better or run faster, leading to actual attempts to do these things, than to any expected results of mere mental wishing or willing. The essential principle of Lamarckism is an orthogenetic evolutionary progress toward better and finer adaptation and adjustment resulting from the inherited effects of actual use, disuse, and functional stimulation of parts. It is a great thought and a clear one, and only needs the proof of the actuality of the inheritance of individually acquired characters to make it one of the principal causal explanations of adaptation and species change.

However, it is exactly this proof that is wanting. At any rate, proof of the character and extent necessary to con-

Weismann's vince all or even a majority of biologists is successful attack wanting. The examples or cases brought foron Lamarckism. ward by Lamarckians of the alleged inheritance of mutilations, of the results of disease, and of use and disuse, are not convincing. It is one of Weismann's positive contributions to biology to have analysed case after case of alleged inheritance of acquired characters, and shown its falseness or at least uncertainty. Many of these cases he has been able to explain as a result of selection; others remain inexplicable; a few, ${ }^{2}$ only, are insisted on by the Lamarckian champions as indisputable examples of such inheritance. But this very paucity of so-called proved cases, where there should be thousands of obvious examples if the principle were really sound, is argument against Lamarckism.

Our knowledge, too, of the mechanism of heredity makes strongly against the theory of the inheritance of acquired characters. Another of Weismann's positive contributions 
to biology is his generally sound distinction between the germ-plasm and the soma-plasm and parts of the manycelled body. At maturity the animal body is composed of a small mass of germ-plasm (germ-cells) situated in the ovaries or testes, and a great mass of somatic tissues and organs, all the rest of the body, in fact. Now what is the condition that exists in the body after a somatic part is modified by use or disuse or by other functional stimulus, as when a muscle is enlarged by exercise, the sole of the foot calloused by going barefoot, an ear more finely attuned by training? We have a definite physical change in a definite organ, but is the germ-plasm in any way changed or affected by this superficial or specific somatic modification, or if changed is it changed so that it will reproduce in its future development a similar change in the same organ of the future new individual? What possible mechanism have we in the body to produce or insure such an effect on the germ-plasm? The answer is obvious and flat; we certainly know of no such mechanism; in fact what we do know of the relation of the germ-cells to the rest of the body makes any satisfactory conception of such a mechanism as yet impossible.

Not that certain external conditions may not directly affect the germ-cells, imbedded and concealed as they are Dificulties in in the body. Varying conditions of temperathe way of accepting the inheritance of acquired characters. ture,* of humidity, and of magnetism, perhaps, certainly anything influencing the food supply and nutrition, can influence the germ-cells at the same time as it affects all the rest of the body. But will this influence photograph on these undifferentiated cells the same picture that it impresses on the

* While temperature may be looked on as an extrinsic influence affecting germ-cells as well as all other parts of the body, it must be kept in mind that warm-blooded animals (birds and mammals) regulate the inner temperature of the body. So changes in external temperature would but slightly, or not at all, affect the germ-cells. 
affected somatic parts. A high temperature or a moist atmosphere may modify the colour of the skin, change the pattern of the body superficies, but will overheated germ-cells produce new individuals showing the same changes of skin colour and pattern if the same conditions of environment of the soma are not repeated? How much less conceivable, then, is the infuencing of the germ-cells so as to compel them to reproduce on daughter body-parts specific effects. produced on special parental body-parts by such specific and localised influences as vigorous use of an arm, disuse of a leg muscle, repeated contact of the palm of the hand with hard bodies. Indeed, this lack of means of relating the germ-plasm to the soma, the rest of the body, has stood much in the way of any satisfactory conception of the phenomena of heredity, that is, the reproduction by the germcells of new individuals resembling the parental, and has led to constant and thoughtful attention and speculation ever since the time of Darwin; indeed, from long before Darwin's time.

One of the most favoured ways of attempting to explaim how the germ-cells can represent in their make-up, and possess the capacity to develop into, the whole complex body, has been to conceive of the giving off of small representative particles from all the cells of the body which should be carried by the blood to the germ-plasm and deposited in the germ-cells. The germ-cells in their development would then, by virtue of this manifold representation, be able to expand into the whole body during a shorter or longer course of development and growth. This notion of the composition of the germ-plasm of micromeres collected from all the somatic cells, is the conception at the basis of Buffon's theory of "organic molecules," of Spencer's "physiological units," Maggi's "plastidules," Altmann's "bioblasts," Wiesner's "plasomes," Darwin's "gemmules," Galton's "stirps," Nägeli’s “micellæ," Weismann's "biophors and determi- 
nants," and of numerous other micromeric theories. ${ }^{3} \quad$ But the facts of budding, especially as exemplified in plants, and of regeneration among animals, both of these kinds of phenomena seeming to show that germ-plasm is not necessarily limited to the germ-cells, strictly so-called, have prevented the acceptance of a too rigorous interpretation of Weismann's distinction between the germ-plasm and the soma, and have led to some theories of germ-plasm make-up and disposition differing from the ones proposing a rigid restriction of germ-plasm to the germ-cells. The facts that in many plants any part, as a bit of a twig, say, if cut off, can reproduce the whole plant just as effectively as a seed (germ-cell) can, and that many animals can reproduce considerable and complex parts, if lost by accident or selfmutilation, show that there often resides in somatic cells of much specialisation the capacity to reproduce not only cells of their own kind but others of much variety and different specialisation. So some biologists believe that there is either a net-work of primitive germ-plasm extending throughout the soma cells (Nägeli's idioplasm theory for example), or that each somatic cell (at least those with the capacity of regeneration or reproduction by budding, cuttings, etc.) contains a little primitive germ-plasm stuff besides its own soma-plasm. And some authors have seen in such theories of a widely diffused germ-plasm a mechanism for the transmission from the soma to the central germ-cells of the effects of use, disuse, and functional stimuli derived from external sources. But does even this conception of a diffuse and connected germ-plasm, after all, clear up in any way our difficulty? It makes it easier to see how germ-plasm may be affected by external and superficial influences, but does it explain in any degree how these effects can be carried to the germ-cells and so stamped on them as to compel them to reproduce photographically in their later development into new individuals, the specific effects that use, dis- 
use, and external stimuli may have had on specific soma parts of the parent?

Indeed, Haache ${ }^{4}$ well points out that many or most cases of apparently direct working of extrinsic influences on the body are really indirect, in that these influences

Haacke's discussion. do not actually directly modify the structure, as a blacksmith's hammer modifies the shape of a piece of red-hot iron, or a seal shapes the drop of melted wax, but that they do it indirectly as stimuli inducing chemical processes, nervous impulses, etc. The adaptive rearrangement of spongy tissue in broken and poorly reset long bones, apparently a direct reaction, is really only indirect, occurring through complex chemical processes, $i$. e., the bringing of special bone-forming materials to certain places, etc. The outer influences are all stimuli, not actual sufficient causes or manipulations.

Haacke makes a proposal of much ingenuity, after a keen and suggestive discussion of the inheritance of acquired characters problem, to explain how such an inheritance may be effected. It is based on the fact that no characters are directly acquired; that is, that any change is only the result of some external stimulus and not of a directly and immediately moulding cause, and that, therefore, in any phenomenon of stimulus and effect much more of the body substance than that composing the exact part or region modified is influenced. From this Haacke sees the possibility, even the necessity, of a modification of the whole constitution, including the germ-plasm (or perhaps the germ-plasm is modified as a result of the modification of the whole constitution or body in which the germ-plasm is being developed and formed). Thus every acquirement of a new character or change in an old one must or may affect the germ-plasm. With regard to passive organs such as the chitin skeletal parts of insects and crabs, Haacke points out that they are only the product of active organs, $i$. $e$, the secreting skin- 
cells, etc. Use and disuse are equivalent simply to much or little metabolism, and metabolism is as necessary to produce passive organs or to change them, as use is to make muscles larger.

However, despite the successful destructive criticism by Weismann and the neo-Darwinians of the alleged cases of Many natural- the inheritance of acquired characters adduced ists believe in by the Lamarckians, and in spite of our lack of the inheritance of acquired characters, knowledge, and indeed, difficulty of conception of any mechanism in the body capable of impressing on the germ-plasm the effects of use, disuse, and external stimuli in such a way as to compel a photographic reproduction in the young of these effects as manifest in the soma of the parent, numerous biologists do not hesitate to avow their conviction of the actuality of such inheritance. Now these biologists must have some basis of observation or scientific fact for their belief. What is this basis? They rest their belief largely upon a kind of proof by indirection, a certain necessity of consequence of other facts, and a logical argument by elimination. The actual observed status of animal life to-day and, as revealed by fossils, in past ages, which is that of the existence of certain lines of descent or evolution obviously following lines of modification based on use and disuse; the inadequacy of natural selection to explain the cumulation of adaptive modification until such modification shall have reached a life-and-death determining selective value; the apparent impossibility of explaining the continued degeneration of vestigial organs by natural selection; the great difficulty of explaining correlative or coadaptive modifications by selection alone; the possibility that our lack of knowledge of a mechanism for ensuring the hereditary transmission of acquired characters may be overcome with further knowledge of the ultimate structure and capacity of the germ-plasm; the great reasonableness and logical plausibility of the whole Lamarckian conception; 
these and other similarly not wholly convincing reasons are the sort of not very admirable scientific evidence that the believers in Lamarckism have to stand on. Two groups of scientific men are especially well represented among the Lamarckians: namely, palæontologists and pathologists. (Not all palæontologists and pathologists believe in the inheritance of acquired characters.) Both of these groups are familiar with facts that are unfamiliar to biologists generally. And to my mind it is important that biologists should recognise the fact that familiarity with the facts of historical geology on the one hand and with teratogenesis and human disease on the other, seems to lead to a belief in Lamarckism.* It should lead the general biologist to be less positive in his sureness of the invalidity of Lamarckism.

But even were the inheritance of acquired characters now an established fact, or if it should come to be one, it must

Lamarckism be kept in mind that Lamarckism could be subunable to ex-
plain all adaptaplain all adapta- many adaptations and much species-forming
tions. that Lamarckism might explain, but also there are hosts of adaptations that Lamarckism cannot explain. Plate, ${ }^{5}$ who defends natural selection but accepts some part of Lamarckism, has pointed this out clearly. He asks how the so-called "passive adaptations" could be explained by Lamarckism. "The salivary glands of a non-poisonous snake could produce ever so much saliva, but it would not become poisonous by this, just as little as simple teeth could change by use to grooved teeth and these to tubular ones. The tusks of Babirussa could not be led to grow through the skin of the cheeks through use, for they would have to be actually

* A scientific man representing another phase of biologic activity, and a man who has enjoyed an extraordinary opportunity for the observation and testing of modes of inheritance, also believes strongly in Lamarckism. This is Luther Burbank, the famous California plant-breeder. For some account ${ }^{6}$ of the scientific aspects of Burbank's work, see the appendix of this chapter. 
covered by the flesh for awhile in this process, and during this time be incapable of use. With Fierasfer, the fish that lives in sea-cucumbers (Holothurians), the anus lies far forward in the throat so that the fish has only to thrust its head through the anus of the sea-cucumber in order to void its fæces. How can use of the intestine or its peristaltic movement have produced such a remarkable change in position of the anus?" Plate offers other similar examples of adaptations inexplicable by Lamarckism, and justly says that hundreds of others could be adduced. He presents succinctly the possibilities of Lamarchism, the inheritance of acquired characters being granted, as follows :

Lamarckism could explain

(I) many indifferent characters: example, changes of temperature produce proportional changes in the colour-pattern of butterflies' wings;

(2) many simple adaptations of active organs: example, a muscle becomes stronger through use, and creates a crest on a bone through pulls;

(3) some simple adaptations of passive organs (so-called direct adaptations): example, in the whales, the water might directly affect the skin and sub-cutaneous tissue and thus produce the loss of hair and the layer of fat.

Lamarckism could not explain

(I) many characters of active adaptation, even though of simple kind: example, the penetrating of the lungsacs of birds through hair-fine holes into all the bones;

(2) many complicated adaptations of active organs: examples, light-making organs, eyes, smelling-organs, auditory organs;

(3) all complicated passive adaptations: example, mimicry.

Even if we are ready to admit the possibility or actuality 
of the inheritance of acquired characters in some degree or under certain conditions-and this partial acceptance has always seemed to me no more justified than the flat acceptance of the principle in its entirety; it has seemed a weak sort of attempt at compromise with no real basis in reason and effecting no advantage in clearing up the problemthere can be no acceptance of the all-sufficiency of Lamarckism as an explanation of adaptation, species-forming, and descent, any more than there can be such an acceptance of the all-sufficiency of natural selection. Adaptation and species-forming are not, to my mind, one and the same problem: adaptation can and does lead to species-forming, but species are formed that are not the results of adaptive modification; whose specific characteristics are indifferent; that are, in a word, non-adaptive species. De Vries's new species of evening primroses have a cause not associated with adaptation. Now Lamarckism certainly cannot explain nonadaptive species any better than selection can. Both selection and the inheritance of the effects of use, disuse, and external stimuli are primarily explanations of adaptations. and of adaptive species-forming. Lamarckism is, perhaps, through its inclusion of the perpetuation of the direct influence of external stimuli, in better condition to explain nonadaptive species, but both of these genius-offered explanations of organic evolution need the aid of another or other factors: the unknown factors of evolution, to speak with Osborn.

Orthogenesis.-One of the principal criticisms of the natural selection theory is that of the impossibility of exApparent evi- plaining the beginnings of advantageous modidence for ortho- fication and the beginnings of new organs, by genetic evolution. the selection of fluctuating individual variation, and of explaining the apparent cases of the existence of determinate variation and the admitted cases of forthright development along fixed lines not apparently advantageous, 
and finally of explaining the definite cases of ultra-development of parts and species beyond the point of advantage even to such unfavourable degrees as lead to death and extinction. Palrontology ${ }^{8}$ reveals to us the one-time existence of animals, of groups of animals, and of lines of descent, which have had characteristics which led to extinction. The unwieldiness of the giant Cretaceous reptiles, the fixed habit of life of the crinoids, the coiling of the ammonites and nautili, the gigantic antlers of the Irish stag-all these are examples of development along disadvantageous lines, or to disadvantageous degrees. The statistical studies of variation have made known numerous cases ${ }^{9}$ where the slight, as yet non-significant (in a life-and-death struggle) variation in pattern of insects, in dimension of parts, in relative proportions of superficial non-active structures, are not fortuitous, that is, do not occur scattered evenly about a mean or mode according to the law of error, but show an obvious and consistent tendency to occur along certain lines, to accumulate in certain directions. Many biologists see in variation and in species-forming certain determinate characteristics exhibited by, or lines or paths being followed by all or most of the individuals of successive generations; and see in descent certain phenomena of forthright progressive movement which they find selection based on utility unable to explain. Various theories to account for this apparent orthogenetic, but not ortho-selective, development have therefore been proposed by biologists, most of which theories and most of which biologists are to be looked on as antagonistic to the selection theory. For if a theory of orthogenesis is sufficient to explain those lines of variation and development not explicable by selection, it usually seems to its maker to be sufficient to explain other lines of evolution.

It may very likely occur to some that in speaking of orthogenetic development as contrasted with descent governed by selection we are making a distinction without a difference, 
in that it is obvious that selection also produces orthogenetic evolution, that is, evolution along definite lines; that in fact it can produce no other kind of

Orthogenesis contrasted with orthoselection. evolution. To attribute orthogenetic results to natural selection is quite right, and some one has proposed the name orthoselection to distinguish orthogenetic evolution as produced by selection from such results produced independently, or at least partly independently of selection, that is produced in accordance with any one or more of the so-called theories of orthogenesis. All this latter kind of orthogenesis is distinguished from orthoselection in that it presumes all or most of the individuals of successive generations to be modified, to vary, that is, in a similar manner as a result of factors, intrinsic or extrinsic, producing determinate variation. This is plainly different from orthoselection, in which definite lines of development are produced by the eradication, through the rigour of selective struggle. of all other lines. Variation may be wholly fortuitous, miscellaneous, indeterminate; but selection permits only certain hinds of variation to persist, to accumulate. In true orthogenesis the variation, and hence the lines of modification, are predetermined. It seems obvious, however, to any believer in natural selection that sooner or later the fate of these lines of development wiil come into the hands of selection. And most orthogenesists do indeed admit this. But it is precisely in the making of a start in modification that orthogenesis fills a long-felt want, and if capable of proof, should be gladly received by Darwinians as an important auxiliary theory in the explanation of modification, species-forming, and descent.

The first of these theories of orthogenesis has just been explained, for Lamarckism may be looked on as an explanation of orthogenetic evolution based on the perpetuation and accumulation of the effects of use, disuse, and the direct effects of functional stimuli. Roux's battle of the 
parts theory, and Weismann's theory of germinal selection are also in a way theories of orthogenesis: they explain how variations begin and continue along fixed lines, but they both soon surrender control of descent to natural selection.

There are, however, two or three theories of

Different types orthogenesis which have been developed by of theories of ortbogenesis.

their proposers to the degree where they are boldly offered as substitutes for natural selection. Two especially notable theories of this character are those proposed and defended respectively by Nägeli and by Eimer. These two are not only the most notable and most completely elaborated of orthogenetic theories but they represent two radically different points of view among the orthogenesists themselves, in that Nägeli found his orthogenesis-producing factor or cause in a somewhat mystical vitalistic inner force, or so-called V cririllommungsprinsip. in the organism, while Eimer finds orthogenesis produced and controlled by the directly working external factors of climate, food supply, and environment generally. Similar conceptions or beliefs regarding the direct and accumulating effect of environmental factors have been presented by Darwin, Haeckel, Cope, Henslow, Emery, Piepers, Lloyd Morgan, and numerous others. In fact probably a majority of biologists entertain a conviction,- - often not clearly defined and generally unaccompanied by any satisfactory conception of a mechanism for achieving what they believe to exist,--of the actuality of an infuence on organic modification and descent directly exerted by those various external factors or conditions of organic life which we call, collectively, environment.

Nägeli's ${ }^{10}$ theory of orthogenesis depends upon the assumption of his so-called principle of progressive developNägeli's theory ment (Vcroollkommungsprinsip), a something of orthogenesis, inherent in the organic world which makes each organism in itself a force or factor making towards 
specialisation, adaptation, that is, towards progressive evolution. Other authors who accept such a theory of an inherent driving force in organisms speak of this factor variously as an "inner directive force," an "inner law of development," or an "intrinsic tendency towards progress," etc. Nägeli believes that animals and plants would have developed about as they have even had no struggle for existence taken place and the climatic and geologic conditions and changes been quite different from what they actually have been. Korschinsky ${ }^{11}$ says: "In order to explain the origin of higher forms out of lower it is necessary to assume in the organism a special tendency towards progress." That is, to the believers in this kind of a theory of orthogenesis organic evolution has been and is now ruled by unknown inner forces inherent in organisms, and has been independent of the influence of the outer world. The lines of evolution are immanent, unchangeable, and ever slowly stretch toward some ideal goal. It is needless to say that but few biologists confess to such a belief. However much in the dark we may be regarding the whole great secret of bionomics, however partial and fragmentary our knowledge of the processes and mechanism of evolution, such an assumption of a mystic, essentially teleologic force wholly independent of and dominating all the physico-chemical forces and influences that we do know and the reactions and behaviour of living matter to these influences which we are beginning to recognise and understand with some clearness and fulnesssuch a surrender of all our hardly won actual scientific knowledge in favour of an unknown, unproved, mystic vital force we are not prepared to make. As Plate well says, such a theory of orthogenesis ${ }^{12}$ is opposed, in sharpest contrast, to the very spirit of science.

On the contrary, the theories of orthogenesis of the general type exemplified by Eimer's ${ }^{13}$ are directly in line with the spirit of modern biological methods and investiga- 
tions; they rest on the assumption that physico-chemical factors produce direct effects on the plastic organism, and

Another type of orthogenetic theory. that such effects, repeated and intensified, result in a certain degree of modification or control of variation and evolution. To be sure, there is not yet proposed a very satisfactory mechanism for conveying the environmental influence to, and translating it into definite effect on the course of development, but the obvious fact that environment does strongly affect and modify individual function and structure and the reasonable belief that the modification of the race must ultimately rest on and proceed from the modification of the individual, make the theories of orthogenesis based on environmental influence very suggestive and of distinct scientific value. In addition, too, there is a certain amount of actual evidence of observation for orthogenesis: an evidence of two categories, namely, positive affirmative evidence, ${ }^{14}$ and negative evidence drawn from the inadequacy of other theories, notably natural selection, to explain certain observed phenomena which can be explained on the assumption of an orthogenesis. The general character of this evidence is indicated in our first paragraph treating of orthogenesis. To this may be added an abPlate's résumé stract of Plate's ${ }^{15}$ résumé of the facts or of facts tending stract of Plate's genesis. evidence for orthogenesis (although Plate cau tiously notes that some of these may be only phenomena of orthoselection). These phenomena pointing toward orthogenesis may be grouped into six categories:

r. The "analogous or parallel variations" which have been recognised ever since Darwin's time, he, himself, listing many examples of them. These are variaParallelisms in tions of unmistakably similar character, which
variation.

often appear in different branches of the same large group. "Comparative anatomy reveals many ex- 
amples to show that a definite or determinate direction of modification may be noted in all the sub-groups of a large family, although appearing in unequal degree in different species. Examples are the reduction of the hind toes among the Artiodactyls which has continued in several genera (giraffe, camel, llama) up to a complete disappearance, and the modification of the originally single genital duct into a double and finally triple one, as occurs in both the Pulmonata and the Opisthobranchiata. Often a progressive development can, on mechanical or physical grounds, come about by a modification in but one direction, and may lead thus to convergent changes, as the development of a lens in a pigment fleck in the case of many unrelated lower animals, the similarity of the heart in crocodiles, birds, and mammals, the appearance of a placenta with Pcrmales among the Marsupials and also among the Placentalia."

2. The numerous "excessive structures" which are developed far beyond the limits of usefulness. Examples, the tusks of the wild boar (Babirussa alfurus); the Over-speciali- giant horns of many wild sheep and goats; the enormously elongated thread-like neck of several Rhynchophorous beetles, as Apoderus tenuissimus, etc.; the absurdly long eye-stalks of such crustaceans as Macrophthalmus laterillei and Podophthalmus aigil; Mcsoplodon, whose mouth can be opened but a little when the animal is full grown because on each side an under tooth grows around the upper jaw. Such "excessive structures" have undoubtedly led to the dying out of many former species: examples, the tusks of the mammoth, the antlers of the Irish stag, the canines of Smilodon neogaus.

3. "The constitution, or actual chemical composition of the body permits, in many cases, changes only in few directions. The animal or plant breeder may by no means produce any wished-for form or colour. No one has yet succeeded in producing a blue Maiblume, a grass with divided leaves, a 
hen with a parrot's beak. And we can declare with confidence that a chorda dorsalis can never appear in a beetle.

Constitutional limitations on variation. Through the very fact that an animal belongs to a group the possibilities of variation are distinctly delimited and in many special cases these possibilities may indeed be very narrow." Plate does not mention in this connection the fact that some biologists have seen in this restriction of the range of variation which inevitably accompanies specialisation in the development of animal groups an important factor in the determination of lines of descent. Cope gave much importance to this factor, and very recently Rosa,${ }^{16}$ in a most ingenious and suggestive paper, attributes to this "progressive reduction of variability" a large importance in the dying out of old species and the origin of new ones.

4. "By the correlations which bind each organ to others the range of variation is also restricted.'

5. Many facts of palæontology seem to prove the existence of orthogenetic evolution. "Wherever a large supply of ma-

Facts from terial permits the working out of a phyletic palzontology
supporting orthogenesis. of development, which despite occasional sidebranching rum essentially in straight lines, in steps which lead gradually one to another."

6. The phyletic series (chains of forms) of recent species Single pby. also show, where we are able to trace them, letic lines. distinctive single lines of development.

Eimer's particular theory of orthogenesis, which we have chosen as a representative of the orthogenetic doctrine in general (although few biologists who believe in the principle of orthogenesis accept this theory in detail), may be briefly stated as follows:

Modifications of organisms, that is, lines of evolution, are not miscellaneous, but occur according to control along a few definite directions, these lines of change being deter- 
mined not at all, at least in their beginnings, by selection on a basis of utility, but as the result of the inheritance of acquired characters and according to the laws Eimer's theory of organic growth (organophysis). The prin-
of orthogenesis.

cipal effects of these laws of organic growth are made manifest by the determinant evolution, or orthogenesis, which obtains, and which is in direct contrast to that kind of evolution which natural selection, if it really effected anything, would bring about. For evolution by natural selection would occur along all sorts of heterogeneous and radiating lines which is, according to Eimer, actually not the case. A few definite lines obtain from which occasional branches are given off, the whole building the familiar phyletic or genealogical tree. That these main lines and branches are not themselves the result of selection is proved by the fact that much evolution and modification of organisms is not directly useful, a majority, indeed, of the characters distinguishing different species not being characters of utility. ${ }^{17}$ Only when a character or line of evolution becomes of a life-and-death-determining disadvantage can selection interfere with evolution by orthogenesis. And this interference is always and only of the nature of a stamping out, never of the character of the creation of new characters or lines. Eimer believes in the inheritance of acquired characters, believes in a considerable species-forming influence of geographical isolation, that is, finds such isolation very helpful to the general basic organic growth evolution principle and finds the actual causes of orthogenesis "to lie in the effects of external influences, climate, nutrition, on the given constitution of the organism." "This is not Lamarckism," Eimer points out, anxious to have his theory to his own credit, "for Lamarck ascribed to the external influences no effects on the animal body, and only very little on the plant body." Eimer adds that the effects of external influences are usually considered a part of Lamarckism; 
as a matter of fact Lamarck's species-forming influences were, chiefly at least, the inherited results of actual use or disuse, or of other functional stimulation initiated or exercised actively by the organism itself. In the actual variation of organisms Eimer sees none of that "oscillation" or equal variation around a median or modal point characteristic of the Darwinian conception, but sees always a determinate variation in a few definite lines. He denies positively any capacity on the part of natural selection to create species, finding it effective in breaking the continuous organic chain, that is, of separating it into species, only when aided by geographical isolation. The actual species-forming, that is, the breaking up into specific units of the orthogenetic lines of change instituted by his dynamic factors, he finds to depend on three chief moments, viz.. a standing still or cessation of development (Entricklungsstillstand); a sudden development by leaps, called halmatogenesis (which is almost exactly the fundamental idea in Korschinsky's and de Vries's later heterogenesis theory) ; and third, a hindrance or difficulty in reproduction (which is the essential factor in Romanes's theory of physiological selection proposed ten years later). It is of interest to note Eimer's claim to the original conception of species-forming both by heterogenesis and through physiological selection, with which two theories the names of de V ries and Romanes, respectively, are commonly associated as those of the original proposers.

Of Eimer's three species-forming factors he lays most stress on the one I have first mentioned viz., Entwicklungsstillstand. "The origin of species depends essentially on Entricklungsstillstand or Genepistase, that is, the standing still of certain forms at definite stages in the developmental line, while others go on." This permits of the origin of numerous different species in the same locality or region, without any need of isolation. As orthogenesis modifies, that is, causes to vary in the same way, many individuals at 
a time, it is easy to see that if some of these produce young which do not proceed farther along the orthogenetic line, that is, do not vary farther, while others produce progeny that tend to move on along the line or lines of determinate variation, new species can be dropped, as it were, out of thr general course of the orthogenetic evolution all along. An if these persist we have a series of distinct organic forms all related chainwise although living simultaneously and in the same region. This cessation of development can lead to many added new forms when it occurs in the form of Heterepistase, that is, where only a few characteristics remain fixed at some early developmental stage while others go on. By the fixing or cessation of development in different small groups of characteristics, and in different combinations of these groups many new species may result. All cases of so-called atavism are interpreted by Eimer simply as examples of his Entruicklungsstillstand, this cessation of development occurring in the atavistic organs at a very early stage.

We should not omit mention, in connection with Eimer's theory, of a point upon which he lays great stress, and that is that his theory is not the result of pure speculation, but is the unavoidable conclusion arrived at by long years of specific observations and study of the facts obtaining in the case of the relations, conditions, and course of evolution of certain groups of organisms. Eimer made careful and extended studies of the wing-patterns of two large groups of butterflies, and of certain lizards and birds, and it is on the basis of these studies in particular that his theory was formulated. It is certainly to be admitted that his exhaustive and most suggestive account of the relations of species and patterns in the swallow-tailed and certain other butterflies makes a very strong argument against the validity of natural selection as an explanation of these conditions. And the example of Eimer's prolonged and minute study of 
actual facts as a basis for his theory and hypothesis building is one which has not been always followed by biological generalisers. It is to be regretted that the polemical and personal character of much of Eimer's writing has tended to make his whole work less regarded than it ought to be by biologists.

That Eimer's theory does not include in any degree the assumption of an inner directive or progressive force the following quotation from Eimer himself shows: "According to my investigations the chief cause of transformation [of species] is that determined definitive organic growth (organophysis) whose expression is a definite determined development (orthogenesis), which is imposed on the plasma by constant outer influences, climate, and nourishment. . . Apart from the fact that the Nägelian assumption of a definite determined development is a hypothetical one, not proved by facts, the zoologist can hardly accept the existence of such a dominant inner factor ever pushing toward advance, when he recalls the host of regressive structures which he has to see. This tendency to progress based on the assumption of 'inner growth laws' contradicts flatly the assumption of outer influences as causes of change. . . And it is my belief that it is precisely these outer influences. and the physiological phenomena dependent on them, which are the determining factors in the phyletic development just as they are in individual development." 18

Among American biologists who have been believers, in some degree, in Lamarckism or some other form of orthogenetic evolution, Cope is the one who has most Cope's orthogenetic theory.

definitely formulated his beliefs into a complete theory of the method of creating and guiding variation and descent lines. Cope's theory may be called one of bathmism (growth-force), kinetogenesis (direct effect of use and disuse and environmental influence), and arch- 
æesthetism (influence of primitive consciousness). In an essay $^{10}$ first published by Cope in 187 I the following hypotheses were presented. (These hypotheses are stated here in Cope's own words, quoted from the preface of his book "The Origin of the Fittest," I887) :

"I. The law of repetitive addition, in which the structures of animals were shown to have originated from simple repetitions of identical elements.

"2. The existence of an especial force which exhibits itself in the growth of organic beings, which was called growth-force, or bathmism.

"3. That development consists in the location of this energy at certain parts of the organism.

"4. That this location was accomplished by use or effort, modifying and being modified by the environment; or the doctrine of kinetogenesis.

"5. That the location of this energy at one point causes its abstraction from other points, producing 'complementary diminution' of force at the latter.

"6. That the location of this energy, so as to produce the progressive change called evolution, is due to an influence called 'grade influence.'

"7. That inheritance is a transmission of this form of energy, which builds in precise accord with the sources from which it is derived.

"8. That this 'grade influence' is an expression of the intelligence of the animal, which adapts the possessor to the environment by an 'intelligent selection.'

"9. An attempt to account for the origin of 'mimetic analogy' by 'maternal impressions.',

In later writings ${ }^{20}$ Cope subdivides his kinetogenesis principle, or the influence of use, disuse, and environment, into a physico-chemical influence affecting the organism through molecular effects, which he calls physiogenesis, and a mechanical influence affecting the organism through molar 
effects, for which the term kinetogenesis is retained. The modifications produced by these two classes of influences "are supposed to be the result of the action of the causes in question continued throughout geologic time." These modifications are assumed to be inherited. In the animal kingdom kinetogenesis, or the modifying influence of motion, is assumed to be the more potent efficient cause of evolution; in the plant kingdom, physiogenesis. The general standpoint of Cope's theory is thus strictly Lamarckiarr. But he adds to this reformulation of general Lamarckism a remarkable feature which he calls archrsthetism. This is. the doctrine that "animal movements are primitively determined by sensibility or consciousness" and that this "consciousness has been and is one of the primary factors in the evolution of animal forms." That is, the kinetogenesis which is the chief causo-mechanical factor of the evolution of the animal kingdom, from primitive single-cell type to most complex Metazoan, has for its own initiation conscious effort. Thus Cope is forced to assume, which he does, that "conscious states have preceded organisms in time and evolution." The formal statement of this phenomenon, then, has to be the thesis that energy can be conscious. "If true," writes Cope, "this is an ultimate fact, neither more nor less difficult to comprehend than the nature of energy or matter in their ultimate analyses. But how is such a hypothesis to be reconciled with the facts of nature, where consciousness plays a part so infinitesimally small? The explanation lies close at hand, and has been already referred to. Energy become automatic is no longer conscious, or is about to become unconscious." Cope holds then that "consciousness was coincident with the dawn of life," and that "evolution is essentially a process of mind. The source of the consciousness, which is back of it, is at present an unsolved problem."

Cope was a palæontologist, ${ }^{21}$ and his belief in the necessity 
of some factor or factors besides that of natural selection to explain evolution lines as revealed by palæontological study is shared by a large majority of the recognised American palæontologists. Osborn of Columbia, Williston of Chicago, Hyatt of Boston, Smith of Stanford, studying respectively the fossil mammals, the reptiles, and the molluscs, all voice their belief in the existence of evidence in the history of the evolution of these animal groups for orthogenetic variation and descent.

Recently Whitman, the Nestor of American zoologists, has declared himself strongly as an adherent of the actuality

Whitman's expression in favour of orthogenesis. of orthogenetic evolution. For many years Whitman has been studying the variations and inheritance in pigeons, and through this work in particular he has become convinced that species-forming variation does advance in a definite direction as well as in various directions. He says," "natural selection, orthogenesis," ${ }^{3}$ and mutation appear to present fundamental contradictions; but I believe that each stands for truth, and reconciliation is not distant. The so-called mutations of Enothera are indubitable facts; but two leading questions remain to be answered. First, are these mutations now appearing, as is agreed, independently of variation, nevertheless a production of variations that took place at an earlier period in the history of these plants? Secondly, if species can spring into existence at a single leap, without the assistance of cumulative variations, may they not also originate with such assistance? That variation does issue a new species, and that natural selection is a factor, though not the only factor, in determining results, is, in my opinion, as certain as that grass grows although we cannot see it grow. Furthermore, I believe I have found indubitable evidence of species-forming variation advancing in a definite direction (orthogenesis), and likewise of variations in various directions (amphigenesis). If 
I am not mistaken in this, the reconciliation for natural selection and orthogenesis is at hand" (p. 4).

In the category of determinate or orthogenetic variation should be included Delage's ${ }^{2 t}$ not very clearly distinguished

\section{Delage's the-} ory of general variation. variation générale. "We call by the name of general variation," he says, "that which appears at one time in all the individuals of a race or at least a large number of individuals and which affects, most often, several characteristics, if not all, in various degrees of strength. Variations of this sort must be due to modifications of the germ plasm produced either by the reducing division, or by fertilisation, or by accidental alterations which this plasm undergoes in its various divisions." It is to these variations, according to Delage, that specieschange is due. The inducing influences which result in the appearance of general variations are use and disuse and the "conditions of life" (nutrition and climate).

As forming a sort of link between the theories of orthogenesis and those of heterogenesis (to be discussed in the

Jaeckel's theory of next chapter), may be mentioned the rather metakinesis. vague and unformed theory of Jaeckel, ${ }^{25}$ the Berlin palæontologist, called "metakinesis." Jaeckel believes, from a study of fossil animal series, that there exists evidence of orthogenetic descent, but that while genera and fanilies may show continuous phyletic series, species appear sporadically, suddenly, and without special reference to the phyletic series. He believes that many cases of epistasis occur: that is, that many sexually mature animals show arrests of development in early ontogenetic stages, and have therefore given up a former further development. He finds numerous examples of this condition among fossil crinoids and trilobites and living selachians. What his theory of metakinesis really seems to be is a combination of the sudden, definitive appearance of new species, which is the essential conception in the theories of 
heterogenesis (explained in the next chapter), with the determinate lines of change or descent, which is the essential idea in orthogenesis.

\section{APPENDIX.}

${ }^{1}$ Lamarck, I744-1828, the "founder of the complete modern theory of descent, is the most important figure [in the history of the References to theory of evolution] between Aristotle and Darwin" Lamarck's (Osborn, "From the Greeks to Darwin,” p. I56. I899). writings,

His theory of descent and the causes of descent was presented in his "Philosophie Zoologique," a large work published in I809. For a brief account of Lamarck's life and work, see Osborn, "From the Greeks to Darwin," pp. I56-I8I, I899. For an exhaustive account with full quotations from Lamarck's exposition of his theories, see Packard, "Lamarck, His Life and Work," I9or. For expositions of the Lamarckian point of view compared with the Darwinian position, see Haeckel, E., "Die Naturanschauung von Darwin, Goethe, und Lamarck," I882 ; Lang, A., "Zur Characteristik der Forschungswege von Lamarck und Darwin," I889; Ward, L. F., "NeoDarwinism and Neo-Lamarckism," Proc. Biol. Soc., Wash., Vol. VI, pp. II-7I, I89I ; Hutton, F. W., "Darwinism and Lamarckism, Old and New," I899; Pauly, A., "Darwinismus und Lamarckismus," I905.

${ }^{2}$ Among the more conspicuous of these cases are Brown-Séquard's epileptic guinea-pigs, Hyatt's Planorbis shells, Cunningham's flat-

Brown-Sé- fishes, and Fischer's butterflies. Morgan, in "Evoquard's experi- lution and Adaptation," gives the following account ments on gninea- and discussion of the Brown-Séquard experiments pigs. and results: "The best direct evidence in favour of the Lamarckian argument is that furnished by the experiments of BrownSéquard. He found. as the result of injury to the nervous system of guinea-pigs, that epilepsy appeared in the adult animal, and that young born from these epileptic parents became also epileptic. Still more important was his discovery that, after an operation on the nerves, as a result of which certain organs. the ear or the leg, for instance, are affected, the same affection appears in the young born from such parents. These results of Brown-Séquard have been vouched for by two of his assistants, and his results in regard to the inheritance of epilepsy have been confirmed by Obersteiner, and by Luciani on dogs. Equally important is their later confirmation, as far as the main facts go, by Romanes.

"Brown-Séquard gives the following summary of his results. I follow Romanes' translation in his book on 'Darwin and After 
Darwin,' where there is also given a careful analysis of BrownSéquard's results, as well as the outcome of the experiments of Romanes himself. The summary is as follows:-

"I. Appearance of epilepsy in animals born of parents which had been rendered epileptic by an injury to the spinal-cord.

"2. Appearance of epilepsy also in animals born of parents which had been rendered epileptic by section of the sciatic nerve.

"3. 'A change in the shape of the ear in animals born of parents in which such a change was the effect of a division of the cervical sympathetic nerve.

"4. Partial closure of the eyelids in animals born of parents in which that state of the eyelids had been caused either by section of the cervical sympathetic nerve, or the removal of the superior cervical ganglion.

"5. Exophthalmia in animals born of parents in which an injury to the restiform body had produced that protrusion of the eyeball. This interesting fact I have witnessed a good many times, and seen the transmission of the morbid state of the eye continue through four generations. In these animals modified by heredity, the two eyes generally protruded, although of the parents usually only one showed exophthalmia, the lesion having been made in most cases only on one of the corpora restiformia.

"6. 'Hæmatoma and dry gangrene of the ears in animals born of parents in which these ear alterations had been caused by an injury to the restiform body near the nib of the calamus.

"7. 'Absence of two toes out of the three of the hind-leg, and sometimes of the three. in animals whose parents had eaten up their hind-leg toes, which had become anæsthetic from a section of the sciatic nerve alone, or of that nerve and also of the crural. Sometimes, instead of complete absence of the toes, only a part of one or two or three was missing in the young, although in the parent not only the toes, but the whole foot was absent (partly eaten off, partly destroyed by inflammation, ulceration, or gangrene).

"8. Appearance of various morbid states of the skin and hair of the neck and face in animals born of parents having had similar alterations in the same parts as effects of an injury to the sciatic nerve.'

"Romanes, who later went over the same ground, in part under the immediate direction of Brown-Séquard himself, has made some important observations in regard to these results, many of which he was able to confirm.

"He did not repeat the experiment of cutting the cord, but he found that, to produce epilepsy, it was only necessary to cut the 
sciatic nerve. The 'epileptiform habit' does not appear in the animal until some time after the operation; it lasts for some weeks or months, and then disappears. The attacks are not brought on spontaneously, but by 'irritating a small area of the skin behind the ear on the same side of the body as that on which the sciatic nerve had been divided.' The attack lasts for only a few minutes, and during it the animal is convulsed and unconscious. Romanes thinks that the injury to the sciatic nerve, or to the spinal cord, produces some sort of a change in the cerebral centres, and that it is this change-whatever it is, and in whatever part of the brain it takes place-which causes the remarkable phenomena in question.'

"In regard to Brown-Séquard's statements, made in the $3 d$ and the $4^{\text {th }}$ paragraphs, in respect to the results of the operation of cutting the cervical sympathetic, Romanes had not confirmed the results when his manuscript went to press; but soon afterward, after Romanes' death, a note was printed in Nature, by Dr. Hill, announcing that two guinea-pigs from Romanes' experiment had been born, 'both of which exhibited a well-marked droop of the upper eyelid. These guinea-pigs were the offspring of a male and female in both of which I had produced for Dr. Romanes, some months earlier, a droop of the left upper eyelid by division of the left cervical sympathetic nerve. This result is a corroboration of the series of Brown-Séquard experiments on the inheritance of acquired characters.'

"Romanes states that he also found that injury to a particular spot of the restiform bodies is quickly followed by a protrusion of the eye on the same side, and further, that he had "also had many cases in which some of the progeny of parents thus affected have shown considerable protrusion of the eyeballs of both sides, and this seemingly abnormal protrusion has occasionally been transmitted to the next generation. Nevertheless, I am far from satisfied that this latter fact is anything more than an accidental coincidence.' This reservation is made on the ground that the protrusion in the young is never so great as in the parents, and also because there is amongst guinea-pigs a considerable amount of individual variation in the degree of prominence of the eyeballs. Romanes, while unwilling to deny that an 'obviously abnormal amount of protrusion, due to the operation, may be inherited in lesser degree,' is also unwilling to affirm so important a conclusion on the basis of these experiments alone.

"In regard to Brown-Séquard's 6th statement, Romanes found after injury to the restiform body that hæmatoma and dry gangrene may supervene, either several weeks after the operation, or at any subsequent time, even many months afterward. The disease 
usually affects the upper parts of both ears, and may then gradually extend downward until nearly the whole ear is involved. 'As regards the progeny of animals thus affected in some cases, but by no means in all, a similarly morbid state of the ears may arise apparently at any time in the life history of the individual. But I have observed that in cases where two or more individuals of the same litter develop this diseased condition, they usually do so at about the same time, even though this may be months after birth, and therefore after the animals are fully grown.' Moreover, the morbid process never extends so far in the young as it does in the parents, and it almost always affects the middle third of the ear.' Several of the progeny from this first generation, which had apparently inherited the disease, but had not themselves been directly operated upon, showed a portion of the ear consumed apparently by the same disease. Romanes then gives the following significant analysis of this result. Since a different part of the ear of the progeny is affected, and also a 'very much less quantity thereof, it might seem that the result was due either to a mere coincidence, or to the transmission of microbes. But he goes on to say, that he fairly well excluded both of these possibilities, for, in the first place, he has never observed the very peculiar process in the ears, or in any other parts of guinea-pigs which have neither themselves had the restiform bodies injured, nor been born of parents thus mutilated.' In regard to microbes. Romanes tried to infect the ears of normal guinea-pigs by first scarifying these parts, and then rubbing them with the diseased surfaces of the ears of affected guinea-pigs. In not a single case was the disease produced.

"Romanes concludes that these "results in large measure corroborate the statements of Brown-Séquard; and it is only fair to add that he told me they were the results which he had himself obtained most frequently, but that he had also met with many cases where the diseased condition of the ears in parents affected the same parts in their progeny and also occurred in more equal degrees.'

"We come now to the remarkable conclusion given in BrownSéquard's 7 th statement, in regard to the absence of toes in animals whose parents had eaten off their own hind toes and even parts of their legs. Romanes got neuroses in the animals operated upon, and found that the toes might be eaten off; but none of the young showed any defect in these parts. Furthermore, Romanes repeated the same operation upon the descendants through six successive generations, so as to produce, if possible, a cumulative effect, but no inheritance of the mutilation was observed. 'On the other hand, Brown-Séquard informed me that he had observed this inherited absence of toes only in about one or two per cent. of cases.' It is 
possible, therefore, Romanes adds, that his own experiments were not sufficiently numerous to have obtained such cases.

"In this connection I may give an account of some observations that I made while carrying out some experiments in telegony with mice. I found in one litter of mice that when the young came out of the nest they were tailless. The same thing happened again when the second litter was produced, but this time I made my observation sooner, and examined the young mice immediately after birth. I found that the mother had bitten off, and presumably eaten, the tails of her offspring at the time of birth. Had I been carrying on a series of experiments to see if, when the tails of the parents were cut off, the young inherit the defect, I might have been led into the error of supposing that I had found such a case in these mice. If this idiosyncrasy of the mother had reappeared in any of her descendants, the tails might have disappeared in succeeding generations. This perversion of the maternal instincts is not difficult to understand, when we recall that the female mouse bites off the navel-string of each of her young as they are born, and at the same time eats the afterbirth. Her instinct was carried further in this case, and the projecting tail was also removed.

"Is it not possible that something of this sort took place in Brown-Séquard's experiment? The fact that the adults had eaten off their own feet might be brought forward to indicate the possibility of a perverted instinct in this case also. At least my observation shows a possible source of error that must be guarded against in future work on this subject.

"In regard to the 8th statement of Brown-Séquard, as to various morbid states of the skin, Romanes did not test this, because the facts which it alleges did not seem of a sufficiently definite character.

"These experiments of Brown-Séquard, and of those who have repeated them. may appear to give a brilliant experimental confirmation of the Lamarckian position; yet I think, if I were a Lamarckian, I should feel very uncomfortable to have the best evidence in support of the theory come from this source, because there are a number of facts in the results that make them appear as though they might, after all, be the outcome of a transmitted disease, as Weismann claims, rather than the inheritance of an acquired character. Until we know more of the pathology of epilepsy, it may be well not to lay too great emphasis on these experiments. It should not be overlooked that during the long time that the embryo is nourished in the uterus of the mother, there is ample opportunity given for the transmission of material, or possibly even of bacteria. If it should prove true that epilepsy is due to some substance present in the nervous system, such substances could get 
there during the uterine life of the embryo. Even if this were the case, it may be claimed that it does not give an explanation of the local reappearance of the disease in the offspring. But here, also, we must be on our guard, for it is possible that only certain regions of the body are susceptible to a given disease; and it has by no means been shown that the local defect itself is inherited, but only the disease. Romanes insists that a very special operation is necessary to bring about certain forms of transmission."

The case of the Planorbis shells studied by Hyatt (Proc. Amer. Phil. Soc., Vol. XXXII, p. $6 \mathrm{I}_{5} \mathrm{ff}$.) has been interestingly disHyatt's studies cussed by Le Dantec ("Traité de Biologie," pp. 296 of Planorbis. ff., I903) as follows: "On trouve, dans les terrains très anciens, des coquilles de Céphalopodes qui ont la forme d'une corne de vache et dont la section transversale est à peu près circulaire; en suivant la série des fossiles de cette catégorie dans des terrains plus récents, on constate que ces coquilles, presque droites naguère. se sont enroulées de plus en plus à la manière d'une spirale d'Archimède; nous ne connaissons pas la raison de cette transformation, mais la présence de certains caractères communs permet de considérer comme démontré que les formes enroulées descendent des animaux à coquilles droites. Or, l'enroulement est tellement fort dans certains types que les tours de spire successifs s'impriment les uns dans les autres, donnant naissance à un sillon dorsal dont la genèse mécanique est évidente, puisqu'il résulte sans conteste de la pression du tour de spire précédent sur le suivant.

"Tant que les animaux en question restent aussi nettement enroulés, on peut admettre que ce caractère de l'existence d'un sillon dorsal est acquis individuellement par chaque Céphalopode pour des raisons mécaniques évidentes, le contact des tours de spires.

"Mais voilà qu'à une période plus récente de l'histoire du monde, les découvertes paléontologiques nous montrent que les descendants de ces Céphalopodes à coquille enroulée ont subi un commencement de déroulement et ont maintenant la forme d'une spirale d'Archimède à tours de spires plus écartés les uns des autres et ne se touchant plus; et notez bien que des caractères communs permettent d'affirmer que ces Céphalopodes à moitié déroulés descendent de ceux dont l'enroulement était beaucoup plus serré.

"Or, chose admirable. le sillon dorsal persiste chez ces êtres à coque à moitié déroulée! Cependant il n'y a plus maintenant pression d'un tour de spire sur le tour de spire précédent; nous avons compris mécaniquement la genèse de ce sillon dorsal, quand les tours de spire se touchaient et se pressaient l'un l'autre; et ce sillon persiste en dehors des conditions mécaniques où il a été 
d'abord produit; il se transmet à des descendants dont la coquille est déroulée! C'est done que le patrimoinc héréditaire a été modifié sous l'influence de la production mécanique de ce sillon dorsal, au point de devenir adéquat à cette forme nouvelle d'équilibre; il y a un nouveau patrimoine héréditaire, qui construisant un individu nouveau et son squelette, fera apparaitre, sans pression, le sillon dorsal!"

The results of the experiments of Cunningham on flatfishes are stated by the author, in a paper on "The Problem of Variation," Nat. Sci., Vol. III, p. 285, I893. Cunningham put the very young fish, while still bilaterally symmetrical (in which stage the pigment is equally developed on both sides of the body), into aquaria lighted from below. He found that when the young fish begins to undergo its metamorphosis, the pigment gradually disappears on one side, as it would have done under normal conditions, $i$. e., when they are lighted from above. If, however, the fish are kept for a short time longer. lighted from below, the pigment begins to come back again. "The first fact," says Cunningham, "proves that the disappearance. of the pigment-cells from the lower side in the metamorphosis is a hereditary character, and not a change produced in each individual by the withdrawal of the lower side from the action of the light. On the other hand, the experiments show that the absence of pigment-cells from the lower side throughout life is due to the fact that light does not act upon that side, for, when it is allowed to act, pigment-cells appear. It seems to me that the only reasonable conclusion from these facts is that the disappearance of the pigmentcells was originally due to the absence of light, and that the change has now become hereditary. The pigment-cells produced by the action of light on the lower side are in all respects similar to those normally present on the upper side of the fish. If the disappearance of the pigment-cells was due entirely to the variation of the germ-plasm, no external influences could cause them to reappear; and if there were no hereditary tendency, the coloration of the lower side of the flatfish would be rapid and complete."

Concerning Fischer's highly interesting experimental work, I quote the following paragraph from Fuchs, H. (Biol. Centralbl.,

Fischer's experiments with batterfies.

with Arctia VI, I902) :

"Experimentelle Untersuchungen, ob es möglich sei, durch willkürliche, geeignet gewählte Veränderungen der "äusseren Lebensbedingungen,' besonders der Temperaturverhältnisse, im Tierreiche 
Variationen bei den Arten hervorzurufen, wurden in den letzten Decennien wiederholt angestellt; mit Vorliebe hat man sich dabei als Versuchsobjekte die Schmetterlinge gewählt: ich erinnere $z$. B. an die schönen Versuche von Standfuss und E. Fischer. Das Resultat war-wie ja nach unseren heutigen Anschauungen über den züchtenden Einfluss der Faktoren der Aussenwelt auf alle Organismen eigentlich kaum anders $z u$ erwarten stand-positiv. Eine Frage allerdings, an welche bei diesen Untersuchungen wohl jeder der Forscher dachte, nämlich: ob die auf solche Weise erworbenen Eigenschaften und Abänderungen auch auf die eventuellen Nachkommen übertragen, also vererbt wurden oder doch wenigstens werden konnten, blieb dabei einstweilen unentschieden. Erst kürzlich gelang es E. Fischer, auch für dieses Postulat der modernen Biologie einen vollgiltigen Beweis beizubringen. F. experimentierte mit Arctia caja, dem braunen Bär, der ja auch den meisten Laien-meist wohl unter dem Namen 'deutscher Bär'bekannt sein durfte, ein erfahrungsgemäss für künstliche Variationsversuche besonders geeignetes Tier. Durch willkürlich gewählte Temperaturveränderungen, und zwar durch intermittierende Abkühlungen bis auf $-8^{\circ} \mathrm{C}$., denen die Puppen wiederholt ausgesetzt wurden, erzielte F. stark aberrative Falter, und zwar aberrativ nicht nur bezüglich der 'Farbe und Zeichnung'-wenn auch hier in erster Linie,-sondern auch bezüglich der Form, z. B. der Flügel und der Beine. Dabei hebt F. ausdrücklich hervor, dass in letzterer Hinsicht es sich nicht etwa um Verkrüppelungen handelte, sondern 'die Füsse waren kräftig und mit gut ausgebildeten Krallen versehen.' Unter diesen Varietäten gelangen nun mehrfache Kreuzungen; die Puppen dieser Zucht wurden unter normalen Bedingungen erhalten. Und siehe! von den alsbald ausgeschlüpften Tieren zeigte eine nicht unerhebliche Anzalil die Variationen der Eltern, und zwar im allgemeinen als Kombinationen aus den veränderten Eigenschaften beider Eltern, so dass einige mehr dem elterlichen Männchen glichen, andere mehr dem elterlichen Weibchen. Es ist dieses also, wie F. sagt, ein experimenteller Beweis, dass:

"I. die Art durch die Faktoren der Aussenwelt Veränderungen erfahrt, und dass

"2. diese Veränderungen sich auf die Nachkommen übertragen.

"Die Thatsache der Vererbung erworbener Eigenschaften steht mithin fest, wenn wir auch über das Wesen der rätselhaften dabei stattfindenden Vorgänge, auf Grund dieser Untersuchungen, natürlich absolut noch nichts sagen können."

To the above cases of the alleged inheritance of acquired characters I may add some account of certain experiments with the mul- 
berry silkworm carried on by R. G. Bell and myself. (For detailed account of this work see Science, N. S., Vol. XVIII, pp. 74I-748, I903.)

"One of the races of the mulberry silkworm, Bombyx mori, has been the subject of experiments directed toward a determination of the exact quantitative relation which quantity and quality of food bear to the development and variations of the individual insect and its progeny....

"The insect, Bomby mori, has a complete metamorphosis, taking no food as an adult, so that the experimental control of the Experiments feeding has been necessary only during the larval or with silkworms. 'silkworm' stage. The larval life is subdivided into five stages clearly set off from one another by the intervening moults, of which there are normally four, and these substages have been useful when an alteration of food conditions during a sharply defined shorter time than the entire larval life was desirable. ... The change in quantity of food has consisted in altering the amount of nulberry leaf served to the larvæ, the control of which has been secured as follows: It has been determined through experience with normal larvæ that each will consume a certain amount of food in a certain number of hours (increasing in amount with the increasing age and size of the larva), this amount representing the optimum amount of food for the normal individual and necessitating as many daily meals as are required to keep any but the moulting larva constantly supplied with fresh food. This amount determined, a tolerably definite small proportion of the optimum amount has been allotted the individuals which were sentenced to short rations, which, roughly speaking. might be listed as one-quarter the optimum amount during earlier stages and one-eighth during the late larval stages. This one-fourth. one-eighth, or whatever it may have been numerically, was, at any rate, as small an amount of food as was compatible with mere life. ...

"These experiments have extended over a period of three years, covering as many generations of the insect. The data gathered (being the measurements, weight, and duration of each larva in each of its five states; the time of spinning, weight of silk and weight and duration of each pupa; and the weight, size, pattern, and fertility of female of each imago) furnish material, then, for a study of the effects of under-feeding upon individuals during a single generation (the 1903 generation or that of 1902 or I90r), during two successive generations (I90I-02 or I902-03), and two alternating generations (I90I-1903) and during three generations (I90I-03), a control lot having been carried for each experimental lot so that what is modified may confidently be distinguished from what is normal. ... 
"In these variously-fed worms there exists a very definite and constant relation between amount of food and size as indicated by weight, the starveling individuals being consistently smaller than the well-nourished, the lingering effects of this dwarfing being handed down even unto the third generation, although the progeny of the famine generation be fed the optimum amount of food; in case the diminished nourishment is imposed upon three, or even two successive generations, there is produced a diminutive, but still fertile, race of Lilliputian silkworms, whose moths, as regards wing expanse, might join the ranks of the micro-Lepidoptera almost unremarked.

"In illustration may be quoted the typical or modal larval weights for each of the lots of 1903 at the time of readiness to spin, which marks the completion of the feeding and is, therefore, an advantageous point for a summary of the results of the three years' experimental feeding.

"The history of the eight lots referred to may be gathered from an examination of the accompanying table, in which ' $O$ ' means optimum amount of food and ' $\mathrm{S}$ ' means short rations. The column to the right indicates the relative rank of the various lots as judged by the modes of frequency polygons erected to include all the individual weights for each lot at spinning time.

\begin{tabular}{|c|c|c|c|c|}
\hline \multirow{2}{*}{ Lot Number. } & \multicolumn{3}{|c|}{ HISTORY OF LOTS. } & \multirow{2}{*}{$\begin{array}{l}\text { Modal Rank. } \\
\text { I9o3. }\end{array}$} \\
\hline & Igor. & $\begin{array}{c}\text { Igo2. } \\
\text { Grandparents. }\end{array}$ & I9०3. & \\
\hline $\begin{array}{l}1 \ldots \ldots \ldots \ldots \\
2 \ldots \ldots \ldots \\
3 \ldots \ldots \ldots \ldots \\
4 \ldots \ldots \ldots \\
5 \ldots \ldots \ldots \\
6 \ldots \ldots \ldots \\
7 \ldots \ldots \ldots \\
8 \ldots \ldots \ldots\end{array}$ & $\begin{array}{l}\mathrm{O} \\
\mathrm{O} \\
\mathrm{O} \\
\mathrm{O} \\
\mathrm{S} \\
\mathrm{S} \\
\mathrm{S} \\
\mathrm{S}\end{array}$ & $\begin{array}{l}\mathrm{O} \\
\mathrm{O} \\
\mathrm{S} \\
\mathrm{S} \\
\mathrm{O} \\
\mathrm{O} \\
\mathrm{S} \\
\mathrm{S}\end{array}$ & $\begin{array}{l}\mathrm{O} \\
\mathrm{S} \\
\mathrm{O} \\
\mathrm{S} \\
\mathrm{O} \\
\mathrm{S} \\
\mathrm{O} \\
\mathrm{S}\end{array}$ & $\begin{array}{l}1 \\
6 \\
3 \\
7 \\
2 \\
5 \\
4 \\
8\end{array}$ \\
\hline
\end{tabular}

"We find that control lot I, consisting of normally-fed individuals of normal ancestry, holds first rank in weight, as was to be expected. Second comes lot 5, whose grandparents experienced a famine but whose parents as well as themselves enjoyed years of plenty. Lots 2 and 3 have likewise had one ancestral generation on short rations, and the fact that they are lighter in weight than lot 
5 illustrates a general rule which obtains throughout the entire company of experimental worms, namely, that the effects of famine grow less evident the further removed the individuals are from its occurrence in their ancestral history. Thus lot 5 is two generations removed from the famine of Igor, while lot 3 has had but one generation in which to recover its ancestral loss. Lot 2, which has had a total of but one famine year-the current year-nevertheless ranks below lot 7 , which has had two famine years in its ancestry succeeded by plenty during the current year. Lot 2 also ranks below lot 6 , a fact which appears strange. considering that lot 6 has suffered two generations of famine, including the current year, which is the only famine year experienced by lot 2 . In explanation of this anomalous condition it is suggested that possibly the larvæ of lot 6 were better fitted for enduring and making the best of hard conditions than were the individuals of lot 2 , the ancestors of the former lot having been selected two years ago on a food-scarcity basis. This suggestion gathers support from an inspection of the mortality notes, from which it appears that the number of deaths-for which the famine was probably a contributing and not a primary cause-in each lot which is for the first time subjected to short rations is almost doubly greater than the number of deaths in lots which are descended from starved ancestors, whether these ancestral famines occurred in successive or alternate years. The figures indicate that a reduction of food is almost twice as destructive upon the first generation which is subjected to it as it is when visited on a second generation. Lot 4 follows lot 2 as the seventh in rank and its position is in accord with the rule above noted. its latest ancestral generation which enjoyed an optimum amount of food during 1902 or 1903. Lot 8 holds lowest rank, it and its ancestors having been subject to trying conditions throughout the entire three years, during some one or two of which all the other lots have enjoyed the best of food conditions. Thus it appears that a generation of famine leaves its impression upon at least the three generations which succeed it, yet the power of recovery through generous feeding exhibited by the progeny of individuals subjected to famine, is so extensive (witness lot 5) that it appears probable that every trace left by the famine upon the race would eventually disappear. It is even conceivable that the ultimate result of the famine would be a strengthening of the race, the famine having acted the part of a selective agent, preserving only the strong.

"But although there is a large difference between the well fed and the poorly fed, there persists, more obviously in late than in early life, a very considerable discrepancy as to size among the 
individuals of each single lot whose environment, in so far as food, temperature, room. humidity, etc., constitute it, is identical.

"For example, referring again to the weights at spinning time of the larvæ of 1903. it is true that, although each lot has a modal class of weights to which the majority of its individuals belong and about which the rest of the lot distributes itself rather symmetrically, the extremes are surprisingly distant from one another. Thus in lot I (the normal control lot) the extremes are I.540 and 2,530 mg.; in lot 2,* SoO and $1.402 \mathrm{mg}$; in lot 3, I, ISo and 2,I70 mg.; in lot 4, 690 and $1.204 \mathrm{mg}$.; in lot 5, I,370 and 2,100 mg.

"That is to say. identical feeding has not made identical fullgrown larvæ out of individuals which undoubtedly varied congenitally at the start, those variations-in embryo-standing at birth in the same relation to one another that they stand in the adults, having merely been smaller and less readily discernible in early life, although manifestly present in delicately measurable degree in the earliest records made upon normal individuals. For example, weight measurements taken immediately after the second moult, range in one lot from $2 \mathrm{I}$ to $39 \mathrm{mg}$., or 60 per cent. of the modal weight, while the weights in this same lot at spinning time, some five weeks later, range from 534 to $2.080 \mathrm{mg}$., or 85 per cent. of the mode for the lot. These embryonic but potentially large variations have simply 'grown up' along with the insect and are as truly congenital in the adult as they were in the newly hatched larva. This would seem to place quite conclusively in the category of congenital variations some part of those variations (in size and proportions of parts) which are commonly, and properly to some degree, called acquired.

"That conditions of alimentation bear a directive relation to functional activity, may be demonstrated by reference to the records of the physiological functions of moulting, spinning, pupating, and emerging, of the individuals of the experimental lots.

"An abnormal extension of the time needed for the metamorphosis follows upon a reduction of the food supply. The degree of extension depends with the utmost nicety upon the amount of food given the larvæ. For example, among the Igor generation of silkworms, one control lot of twenty larvæ was given the optimum amount of food, a second lot of twenty larvæ one-half this amount, and a third lot of twenty larvæ one-quarter of the amount. To take the time of the fourth moulting as an illustration, the moulting was begun by the first lot, which led the way by two and a half days, at the end of which the second lot began to moult, while

* See table, next page, for the history of each lot. 
the third lot was twenty-four hours behind the second. All the individuals of the first lot had finished moulting on April 20, all of the second on April 24, while the moulting in the third lot continued until April 29.

"As in the matter of weight, this retarding of the functions, by means of a reduced food supply, affects not only the immediate generation which is subjected to the famine, but the lingering effects of it may be traced in the progeny of the dwarfed individuals at least unto the third generation, even though two years of plenty follow the one year of famine. The conditions which obtain in each lot of individuals of the 1903 generation at spinning time are shown in the accompanying table, which is based upon polygons erected to include all the individuals in each lot.

\begin{tabular}{|c|c|c|c|c|c|c|c|}
\hline \multirow{3}{*}{$\begin{array}{l}\text { Lot } \\
\text { Num- } \\
\text { ber. }\end{array}$} & \multirow{2}{*}{\multicolumn{3}{|c|}{ HISTORY OF LOTS. }} & \multicolumn{4}{|c|}{$\begin{array}{c}\text { RANK OF I903 LOTS AS TO PROMPTNESS } \\
\text { IN SPINNING. }\end{array}$} \\
\hline & & & & \multirow{2}{*}{$\begin{array}{l}\text { Earliest } \\
\text { Spinner. }\end{array}$} & \multicolumn{3}{|c|}{$\begin{array}{l}\text { When Two-thirds of Each Lot } \\
\text { were Spinning. }\end{array}$} \\
\hline & $\begin{array}{l}\text { Igot. } \\
\text { Grand. } \\
\text { parents. }\end{array}$ & $\begin{array}{l}\text { Igo2. } \\
\text { Parents. }\end{array}$ & 1903. & & Date. & $\begin{array}{l}\text { In Order } \\
\text { of Rank. }\end{array}$ & $\begin{array}{l}\text { Latest } \\
\text { Spinner. }\end{array}$ \\
\hline I..... & $\mathrm{O}$ & $\mathrm{O}$ & $\mathrm{O}$ & I & May I2 & I & I \\
\hline $2 \ldots \ldots$ & $\mathrm{O}$ & $\mathrm{O}$ & $\mathrm{S}$ & 5 & “ 25 & 4 & 4 \\
\hline $3 \ldots$. & $\mathrm{O}$ & $\mathrm{S}$ & $\mathrm{O}$ & 2 & “ 13 & 2 & 3 \\
\hline $4 \ldots .$. & $\mathrm{O}$ & S & $\mathrm{S}$ & 4 & “ 26 & 5 & 5 \\
\hline $5 \ldots \ldots$ & S & $\mathrm{O}$ & $\mathrm{O}$ & 3 & 13 & 2 & 2 \\
\hline & $\mathrm{S}$ & $\mathrm{O}$ & $\mathrm{S}$ & 6 & 29 & 6 & 7 \\
\hline $7 \ldots \ldots$ & $S$ & $\mathrm{~S}$ & $\mathrm{O}$ & 6 & “ 22 & 3 & 5 \\
\hline $8 \ldots$. & $\mathrm{S}$ & ${ }^{4} \mathrm{~S}$ & $\mathrm{~S}$ & 7 & “ 30 & 7 & 6 \\
\hline
\end{tabular}

"This period in the life of the silkworms is particularly advantageous for consideration here, because it marks the completion of the feeding, so that the individuals of under-fed ancestry have been given the best chance to recover, while those subject to altered food conditions, had had the benefit of the alteration during the entire food-taking period of life.

"In the table, 'O' means optimum amount of food, and ' $\mathrm{S}$ ' means short rations. To the right of the history of the lots is a section showing the rank of the lots as to the extreme time limits of the spinning time (emphasised congenital differences again), with a safer criterion, as to their relative promptness, in the column between the extremes-a column of figures intended to show the relative promptness with which a two-thirds ${ }^{\circ}$ majority of the larvae 
in each lot arrives at the spinning time, this proportion being taken to represent the typical condition for the lot. The order in which the lots are arranged in this column corresponds in a general way with that prevalent for the weights at spinning time, and the generalisations indulged in there may, with few exceptions, be applied here. The lots which were well fed during the 1903 generation are ahead of all of those given short rations in 1903 , whatever ancestry they may have had. Lot I leads here as in the matter of weight. Lots 3 and 5 tie for second place, having held second and third places in weight. Lots 2 and 4 stand in the same relation to one another that they held as to weight. Contrary to the weight relation, lot 6 follows lot 2 at the spinning-a fact which illustrates again the general rule that two generations of famine are more disastrous than one, but does not lend support to the notion of natural selection on a food scarcity basis as previously suggested. Lot 8 , which has had no relief from famine during the entire three years, brings up the rear at the spinning, as might be expected.

"This check upon functional activity exercised by diminished nourishment affects the moulting, the time for the commencement of spinning, and the issuing time for the adults. but the time spent in the spinning of the cocoon, from its beginnings in the threads of the supporting net to its apparent completion when the cocoon becomes opaque, is practically identical for under-fed and wellfed individuals. A reason for this exception to the tardy habits of the under-fed is to be found in the fact that the under-fed larvæ produce less silk (less in size, thickness, and weight) than the well-fed, thus accomplishing more meager results in the same amount of time. That the individuals sentenced to short rations should produce less silk than their well-fed neighbours is certainly to be expected, silk not being made without leaves any more readily than bricks without straw.

"Not only do short rations protract the time appointed for the spinning, moulting, etc., but they appear to have a more striking effect upon the actual occurrence of the moulting. The normal number of moults for the silkworm larva is four. Five moults have occurred for most of the individuals belonging to the underfed lots of 1902 and 1903, whereas none of the well-fed individuals has undergone a fifth moult. It would seem. therefore, that the occurrence of a fifth moult may be fairly ascribed to a reduction of food; at least a fifth moult very frequently accompanies it and has suggested the possibility that the enforced fasting of the underfed larva-in the intervals between meals-may have the same physiological effect as the normal fasting which precedes the normal 
moulting, during which time the so-called 'moulting fluid' is secreted. That this effect may accumulate throughout the lifetime of the larva until the larva is actually forced to indulge in the extravagance (of strength, feeding time, and body wall material) of an additional moult is conceivable and will justify a further test.

"As to the life-and-death selection due to famine, it may be said, in addition to the previous discussion of mortality among the experimental silkworms, that while lots subjected to two years of famine (themselves in one year, their parents in the year before) were fertile in so far as number of young hatched is concerned, it was found to be exceedingly difficult to rear from them a 1903 generation. Indeed, at the time of the second moulting there were but nineteen individuals (and tolerably vigorous larva they were) alive in the lot which had experienced two years of famine, although every individual of the 149 hatched was carefully preserved and royally fed-a fact which goes to prove that the equipment at birth of many of these larvæ was inadequate.

"The fact that some larvæ of starved ancestry have exhibited a superiority over their fellows, in surviving and recovering from hard conditions, is testimony for the existence of individual variations which cannot be defined anatomically, and yet which serve as 'handles' for natural selective agents. Such variations might be called physiological variations, since it seems that the surviving larvæ must be those which are in best trim physiologically. These larva are able to make the most of the food offered to them. If competition were allowed, they would probably be the individuals which would cover the area most rapidly, securing whatever food there might be. But under our experimental conditions there was no competition allowed and yet certain precocious individuals made more grams of flesh and more yards of silk, than other larvæ furnished with the same amount of raw material under like conditions; that this was due to the possession by the former of certain congenital qualities of adaptability can scarcely be doubted.

"As to the fertility of the variously fed lots, in so far as number of eggs produced is a measure of fertility, our records already demonstrate the fact that the better nourished are the more fertile. Furthermore, the economy in this matter practised by the starvelings is not merely numerical, quality as well as quantity of eggs being affected. In witness of this point may be recalled the story of the dying 1903 generation, produced from eggs of the starvelings of I9OI and I902. which would seem to offer conclusive evidence that a famine suffered by the parents works its way into the germcells so that most of their progeny have but a poor birthright." 
For special discussions of the inheritance of acquired characters, see the following: Roth, E.. "Die Thatsachen der Vererbung." I885; Ziegler, E.. "Können erworbene pathologische Eigenschaften vererbt werden und wie entstehen erbliche Krankheiten und Missbildungen," I886; Rohde, F., "Über den gegenwärtigen Stand der Frage nach der Entstehung und Vererbung individuellen Eigenschaften und Krankheiten," I896; Osborn. H. F., "Are Acquired Variations Inherited," I890; Elliott. D. G.. "The Inheritance of Acquired Characters," Auk, Vol. IX. pp. 77-I04. I892; Packard, A. S., "On the Inheritance of Acquired Characters in Animals with Complete Metamorphosis," Proc. Amer. Acad. Science, pp. 33I370, I894; Ritter. W. E., "On the Nature of Heredity and Acquired Characters, and the Question of the Transmissibility of these Characters," I900; Wettstein, R. von, "Der Neo-Lamarckismus und seine Beziehungen zum Darwinismus," I903; Detto, Carl, "Theorie der direkten Anpassung," I904 (good bibliography of papers on plant adaptations): Lendenfeld, R. V.. "Variation and Selection," Biol. Centralbl., Vol. XXIII, p. 489 ff., and p. $563 \mathrm{ff.}$ 1903; Pauly A., "Darwinismus und Lamarchismus," I905; Lotsy, J. P., "Vorlesungen über Descendenztheorien," Vol. I, chap. xii, I906; Wheeler, W. M., "The Polymorphism of Ants," Bull. of Amer. Mus. Nat. Hist., Vol. XXIII, pp. I-93. Plate I-VI, January, 1907 (see especially pp. 50-90). Certain writers of sociologic and philosophic interests, have discussed especially the possibility of the inheritance of acquired mental capacities or qualities in man; expressing a belief in such inheritance are Büchner, "Die Macht der Vererbung und ihr Einfluss auf der moralischen und geistigen Fortschritt der Menschheit," I882. and Hartmann, E. V., "Philosophie des Unbewussten," Ioth ed.; against such an inheritance is Rawitz, B., "Urgeschichte, Geschichte, und Politik," 1903. Most important of all the discussions of the inheritance of acquired characters are those of Weismann. Spencer, and Eimer.

A recent American champion of Lamarckism is Caspar L. Redfield, in whose writings ("Control of Heredity," 1903, "Evolution

Redfield's of the Setter," in American Field, I904 and 1905, and position. "Breeding of the Trotter," in The Horseman, I905) is urged the doctrine that acquired mental and dynamic qualities are inherited. On a host of data, derived from the pedigrees and records of trotting horses and setter dogs. Redfield keenly works out his inductions regarding the inheritance by young of the special qualities due to training and practice (acquirement) of the parents; that is, the best offspring (from the sportsman breeder's point of view) come from the best trained parents. There is a great deal of ammunition for the advocates of Lamarckism in Redfield's 
records, although his too sharp distinction between structural and functional (so-called "dynamic") characters is not at all helpful.

The most recent serious treatment of the problem from the neoLamarckian side, and one of great interest and real force, is that Montgomery's of Montgomery in his book on "The Analysis of explanation of Racial Descent in Animals" (I906). Montgomery inheritance of contends that there can be no congenital variation variation.

without external stimuli (or hybridisation) to initiate it, because germ-plasm cannot be assumed to set up change independently and automatically, as this would be almost like the assumption of spontaneous generation. Montgomery says, "When the process of heredity proceeds unchanged the ontogeny of one individual is just like that of its parent. When a change of the ontogeny occurs, so that the offspring comes to be different from its parent, we say that a variation has appeared in the offspring. This variation, it is thinkable, may have been produced: (I) by internal growth energies. (2) by external environmental influences, or (3) by a combination of both; and it is necessary to discuss which one of these is the most probable.

"There is clearly, in the process of production of variation and mutation, some modification of the normal process of heredity. Since in a number of species it has been shown that all the adult individuals from one locality are not exactly alike, but show measurable differences in dimensions, colour, or some other character, it follows that the hereditary process of each such individual must vary correspondingly, even though the variation does not become. perceptible until the stage of maturity. The origin of inherited variation or mutation is then a question of the origin of modification of the hereditary process.

"The regularity of the process of heredity is quite comprehensible on the basis of the direct transmission of definite chromosomes in number, form, and quality constant for the species. From cell to cell, from individual to individual, these chromosomes are regt1larly transmitted in a continuous progress. therefore a succession of similar individuals is quite understandable. One germ-cell comes from a preceding one, to our knowledge is never formed from a specialised tissue-cell, so that there is an uninterrupted passage of the germ-plasm through the race. This is Weismann's idea of the continuity of the germ-plasm, which we will paraphrase as the continuity of the chromosomes.

"A variation to become inherited must then be referable to a modification of the energies of this germ-plasm. The germ-plasm is living substance of proved great importance in the metabolism of the cell. Though in a sense it appears, from microchemical re- 
searches, to be the chief agent in constructive processes of the cell, it equally appears to be incapable of life, or unable to act in a normal manner, when removed from the influence of other cell substances. The food required by a germ-cell for its growth is obtained from without the cell, and must pass through the cytoplasm, in more or less changed condition, to reach the chromatin within the nucleus and there be elaborated into living substance and passed over to the cytoplasm in other form. This conclusion is drawn from both experimental and microchemical studies. So the oxygen required by the cell, and the water, must be obtained from without the cell. This is simply in agreement with the general principle that no body can increase in mass. circumambient conditions remaining unchanged, without accretions from outside. Therefore, the germ-plasm does not so much create new substances as it changes substances brought to it. It and the other celi constituents are harmoniously and mutually interdependent, and the ultimate source of energies of these substances, all connected with the elaboration of living matter, is referable to external agencies because referable to food.

"This being the case, the energies of the hereditable substance, the germ-plasm, are clearly dependent upon influences of the environment. This conclusion is not at all in contradiction with the idea of the continuity of the chromosomes, as we pointed out in the preceding chapter. Therefore, Weismann was in error when, to support his idea of the continuity of the germ-plasm, he at first argued the energies of the germ-plasm to be independent of body cells and of the environment generally. His supposition was both unnecessary for the view of the continuity, and also out of agreement with the phenomena. The ovum cannot elaborate its yolk substance except out of food substance received from without; the amount of its food substance will depend upon the state of nutritive metabolism of the individual carrying the egg-cell; starvation of that individual will cause cessation of energy in the germcell, and ligaturing of the blood-vessels supplying the ovary will produce death of the egg-cells. The results of observational experience teach that the germ-plasm is not a little god, capable of selfexistence without respect to external agencies, but is very intimately bonded to the latter. Whether the germ-cell, as in the sponges. be an amœboid cell which wanders about in the body tissues, or whether it is immovably held in place by tissue-cells, it is impossible that it can live and grow without receiving and reacting to stimuli from these tissue-cells. The egg-cells of many animals are set free in water before they commence to cleave into embryonic cells; how can we say, then, that the conditions in the water do 
not influence them? They will die if removed from the water, and develop abnormally if certain substances be added to or subtracted from the water. But the embryonic differentiation is a result of chromosomal activities, as we have seen; therefore, changes in the medium must influence the germ-plasm. Is not a well-recognised characteristic of living matter, response to external stimuli? How can any living cell be acted upon by stimuli and yet not react to them? There is not a single observation to show that any germcell, or its germ-plasm, is in any way guarded or protected from external stimuli, either by the structure of its cell wall or peripheral cytoplasm, or by the nature of the living tissue that encloses it. And whatever affects the cell body must indirectly affect the chromosomes, because of the physiological connection of the two.

"From such considerations it would seem practically certain that the energies of the chromosomes are to some extent respondent to environmental stimuli. And since observation shows that living matter responds differently, if not always according to the nature of the stimulus at least to its degree, it would follow that change in the nature or degree of the environmental agencies would indirectly engender change in the activities of the germ-plasm. Not to admit this would be to deny to the germ-plasm, without empirical reason, properties proven for all other living substances.

"This thought had long ago been expressed clearly, though from a different line of reasoning, by Spencer (I855). We may state it in another way. Tissue-cells are granted by experimental physiologists the ability of different response, or different intensity of response, to stimuli of different kind or degree. But a tissue-cell is a lineal descendant of a germ-cell, and receives germ-plasm from the latter. Now since the germ-plasm has been transmitted continuously to the tissue-cell, must not the energies of the germplasms of the two be alike at least in their general response activity? Again, a Protozoan may be considered as a cell not exactly correspondent to a germ-cell of a Metazoan, but as something more, as a unit with properties of both a germ-cell and a tissue-cell, for its cytoplasmic differentiations (cilia, contractile vacuoles, cytopharynx, etc.) are comparable to the soma of a Metazoan. In the case of the Protozoan Paramccium, Calkins (1904) has shown that the reproductive activity is increased or diminished according to the amount and kind of food stimuli. Here, then, a Protozoan has its reproductive activities, therefore the energies of its germ-plasm, profoundly influenced by environmental changes; and it is primarily what we may term the germ-cell constituent of the Protozoan that becomes influenced, that part which has to do with reproduction of the individual. Weismann considered the 
Protozoan exactly comparable, in the sense of strict continuity of reproduction, to the germ-cell of a Metazoan, and yet failed to note that a Protozoan can be influenced by environmental change.

"Accordingly, an environmental change may be capable of inducing change in the energies of the germ-plasm. The expression of the energies of this substance, as viewed in temporal succession, constitutes heredity. Therefore, the process of heredity may become modified by a change in the environmental conditions of the germplasm. And since we defined variation as a modification of heredity, a variation could be produced by external infuences acting upon the germ-plasm. understanding by external influences influences of the tissue-cells upon the germ-cells, or, in case the germ-cells are not enclosed. influences of the non-living environment."

In a recent exhaustive paper by Tower, W. L., on "Evolution in Chrysomelid beetles of the genus Leptinotarsa," Publication No. 48 of the Carnegie Institution of Washington, I907, the author, although on the whole a strong adherent of selection as the all-important factor in species-forming, states specifically his belief, on the basis of extensive observation and experiment. that external factors may and do influence the germ-plasm to the extent of compelling it to produce variations. These variations will not be photographic reproductions of modifications of the soma, but they will be the variations which lie at the basis of species change. In other words, Tower holds that variations are epigenetic in their origin, although they are manifest as congenital differences. That is, acquired characters in the usual sense of the term are not heritable, but all variability is nevertheless due to the influence of environment. This paper by Tower is a distinctly valuable contribution to our know1edge of heredity and species change and it is based upon a large amount of actual close observation and experiment.

In a recent paper by Jonathan Wright. "The Origin and Heredity of Matter," in the St. Louis Medical Rericrw, I906, something of the same attitude is taken, although the author is much more inclined to the belief in the general heritability of acquired characteristics. This short paper is an admirable treatment, based on a full acquaintanceship with the modern literature on the subject, of the problem of heredity.

${ }^{3}$ See exposition of a number of these theories in appendix of chapter viii of this book.

"Haacke, W., "Grundriss der Entwicklungsmechanik," p. 289 ff., I897.

'Plate, L., "Über die Bedeutung der Darwin'schen Selectionsprinzip." p. 218, 1903.

${ }^{6}$ The following account of the scientific aspects of Luther Bur- 
bank's work, which has attracted so much attention from evolutionists and the world generally, was published by Kellogg, in the Pop. Sci., Mo., Vol. LXIX, pp. 363-374, 1906.

"Mr. Burbank has so far not formulated any new or additional laws of species-change, nor do his observations and results justify Scientific any such formulation, and we may rest in the belief aspects of Bnr- that he has no new fundamental laws to reveal. $\mathrm{He}$ bank's work. has indeed the right to formulate, if he cares to, some valuable and significant special conclusions touching certain already recognised evolution factors, in particular the influence on variability of the two long-known variation-producing factors of hybridisation and modification of environment. His reliance on the marked increase in variability to be got after a crossing in the second and third generations over that obvious in the first, will come as a surprise to most men first getting acquainted with his work. He has got more starts for his new things from these generations than in any other way. He is wholly clear and convinced in his own mind as to the inheritance of acquired characters; 'acquired characters are inherited or I know nothing of plant life.' he says; and also convinced that the only unit in organic nature is the individual, not the species; that the so-called species are wholly mutable and dependent for their apparent fixity solely on the length of time through which their so-called phyletic characters have been ontogenetically repeated. He does not agree at all with de Vries that mutations in plants occur only at certain periodic times in the history of the species, but rather that, if they occur at all, they do so whenever the special stimulus derived from unusual nutrition or general environment can be brought to bear on them. He finds in his breeding work no prepotency of either sex as such in inheritance, though any character or group of characters may be prepotent in either sex. He believes that no sharp line can be drawn between the fluctuating or so-called Darwinian variations and those less usual, large, discontinuous ones called sports. Ordinary fluctuating variation goes on under ordinary conditions of nutrition. but with extraordinary environmental conditions come about extraordinary variation results, namely, discontinuous, sport or mutational variation. These variations are the effects of past environment also, having remained latent until opportunity for their development occurs. Starvation causes reversions, but reversions can also be produced by unusually rich nutrition. New variations are developed most often, as far as environmental influences go, by rich soil and generally favourable conditions. So-called new qualities are usually, if not always (the fact may sometimes nøt be obvious), simply new combinations of old qualities, both latent and obvious. To get 
a new and pleasing odour it may often be sufficient simply to lose one bad element in an old odour. So one might go on for some pages with specific conclusions or deductions reached by Burbank on a basis of experience. But it is true that he has at his command the knowledge of no new fundamental scientific principles to give him advantage over us. And yet none of us has done what Burbank has been able to do, although many of us have tried. What then is it that Burbank brings to his work of modifying organisms swiftly and extremely and definitely that others do not?

"To answer this it will be advisable to analyse in general terms, at least, the various processes which either singly, or in combinations of two or three, or all together, are used by Mr. Burbank in his work. We may roughly classify these processes and means. First, there is the importation from foreign countries, through many correspondents, of a host of various kinds of plants, some of economic value in their native land and some not, any of which grown under different conditions here may prove specially vigorous or prolific or hardy, or show other desirable changes or new qualities. Among these importations are often special kinds particularly sought for by Burbank to use in his multiple hybridisations; kinds closely related to our native or to already cultivated races which, despite many worthless characteristics. may possess one or more particular, valuable ones needed to be added to a race already useful to make it more useful. Such an addition makes a new race.

"Second, the production of variations, abundant and extreme, by various methods, as (a) the growing under new and, usually, more favourable environment (food supply, water, temperature, light, space, etc.) of various wild or cultivated forms, and (b) by hybridisations between forms closely related. less closely related and, finally, as dissimilar as may be (not producing sterility), this hybridising being often immensely complicated by multiplying crosses, $i . \mathcal{e}$., the offspring from one cross being immediately crossed with a third form, and the offspring of this with still another form, and so on. These hybridisations are made sometimes with very little reference to the actual useful or non-useful characteristics of the crossed parents, with the primary intention of producing an unsettling or instability in the heredity, of causing, as Burbank sometimes says, 'perturbations' in the plants. so as to get just as wide and as large variation as possible. Other crosses are made, of course, in the deliberate attempt to blend, to mix, to add together, two desirable characteristics, each possessed by only one of the crossed forms. Some crosses are made in the attempt to extinguish an undesirable characteristic.

"Third, there is always immediately following the unusual produc- 
tion of variations, the recognition of desirable modifications and the intelligent and effective selection of them, $i$. $e$., the saving of those plants to produce seed or cuttings which show the desirable variations and the discarding of all the others. In Burbank's gardens the few tenderly cared for little potted plants or carefully grafted seedlings represent the surviving fittest, and the great bonfires of scores of thousands of uprooted others, the unfit, in this close mimicry of Darwin and Spencer's struggle and survival in nature.

"It is precisely in this double process of the recognition and selection of desirable variations that Burbank's genius comes into particular play. Right here he brings something to bear on his work that few other men have been able to do. It is the extraordinary keenness of perception, the delicacy of recognition of desirable variations in their (usually) small and to most men imperceptible beginnings. Is it a fragrance that is sought? To Burbank in a bed of hundreds of seedling walnuts scores of the odours of the plant kingdom are arising and mingling from the fresh green leaves, but each, mind you, from a certain single seedling or perhaps from a similar pair or trio. But to me or to you, until the master prover points out two or three of the more dominant single odours, the impression on the olfactories is simply (or confusedly) that of one soft elusive fragrance of fresh green leaves. Similarly Burbank is a master at seeing, and a master at feeling. And besides he has his own unique knowledge of correlations. Does this plum seedling with its scores of leaves on its thin stem have those leaves infinitesimally plumper, smoother or stronger, or with more even margins and stronger petiole, or what not else, than any other among a thousand similar childish trees? Then it is saved, for it will bear a larger, or a sweeter, or a firmer sort of plum, or more plums than the others. So to the bonfires with the others and to the company of the elect with this 'fittest' one. Now this recognition, this knowledge of correlations in plant structure, born of the exercise of a genius for perceiving through thirty years of opportunity for testing and perfecting it, is perhaps the most important single thing which Burbank brings to his work that other men do not (at least in such unusual degree of reliability). Enormous industry, utter concentration and single-mindedness, deftness in manipulation, fertility in practical resource, has Burbank-and so have numerous other breeders and experimenters. But in his perception of variability in its forming, his recognition of its possibilities of outcome, and in his scientific knowledge of correlations, a knowledge that is real. for it is one that is relied on and built on, and is at the very foundation of his success, Burbank has an advantage of true scientific character over his fellow workers, and 
in it he makes a genuine contribution to scientific knowledge of plant biology, albeit this knowledge is so far only proved to be attainable and to exist. It is not yet exposed in its details and may never be, however unselfish be the owner of it. For the going to oblivion of scientific data of an extent and value equivalent, I may estimate roughly, to those now issuing from any half-dozen experimental laboratories of variation and heredity, is the crying regret of all evolution students acquainted with the situation. The recently assumed relations of Mr. Burbank to the Carnegie Institution are our present chief hope for at least a lessening of this loss.

"But let us follow our saved plum seedling. Have we now to wait the six or seven years before a plum tree comes into bearing to know by actual seeing and testing what new sort of plum we have? No; and here again is one of Burbank's contributions (not wholly original to be sure, but original in the extent and perfection of its development) to the scientific aspects of plant-breeding. This saved seedling and other similar saved ones (for from the examination of 20,000 seedlings, say, Burbank will find a few tens or even scores in which he has faith of reward) will be taken from their plots and grafted on to the sturdy branches of some full-grown vigorous plum tree, so that in the next season or second next our seedling stem will bear its flowers and fruits. Here are years saved. Twenty, forty. sixty, different seedlings grafted on to one strong tree (in a particular instance Burbank had 600 plum grafts on a single tree!); and each seedling-stem certain to bear its own kind of leaf and flower and fruit. For we have long known that the scion is not materially influenced by the stock nor the stock by the scion; that is not modified radically, although grafting sometimes increases or otherwise modifies the vigour of growth and the extent of the root system of the stock.

"If now the fruit from our variant seedling is sufficiently desirable; if it produces earlier or later, sweeter or larger, firmer or more abundant, plums, we have a new race of plums, a 'new creation' to go into that thin catalogue of results. For by simply subdividing the wood of the new branch, i. e., making new grafts from it, the new plum can be perpetuated and increased at will. Simple, is it not? No, it is anything but that in the reality of doing it; but in the scientific aspects of it, easily understandable.

"Perhaps it may not be amiss to call attention to what must be the familar knowledge of most of us, and that is the fact that many (probably most) cultivated plants must be reproduced by division, that is by cuttings, buds, or grafts, and not by seeds. in order to grow 'true.' For a piece of a cultivated plant will grow out to be. 
very much like the individual it was cut from, but the seeds will not, in most cases, reproduce faithfully the parents, but will produce a very variable lot of individuals, most of them strongly reversionary in character. Grow peach trees from the stones of your favourite peach and see what manner of peaches you get; but if you want to be sure of more peaches like the ones you enjoy, graft scions from your tree on to other trees. Indeed one of the plant-breeder's favourite methods of making a start for new things, of getting the requisite beginning wealth and eccentricity of variation, is to grow seedlings, especially from cross-bred varieties. Burbank will give you a thousand dollars for a pinch of horseradish seed. Sugar-cane seed is needed. The amelioration of many kinds of fruit and flowers and vegetables is checked, because in our carelessness we have allowed these kinds to get into that condition of seedlessness which almost all cultivated races tend toward when grown from cuttings. In our oranges and grape-fruit and in a score of other fruits, the elimination of seeds is exactly one of the modifications we have bred and selected for, in order to make the fruits less troublesome in their eating. But when we lose the seeds entirely of a whole group of related plant kinds we may find ourselves, as we have found ourselves actually in many cases, at the end of our powers of amelioration of these plant sorts. Burbank believes that the very fact that plants when grown asexually always sooner or later lose their power to produce seeds is almost sufficient proof (if such proof is needed) that acquired characters are transmitted.

"Another of Burbank's open secrets of success is the great range of his experimentation-nothing is too bold for him to attempt. the chances of failure are never too great to frighten him. And another secret is the great extent, as regards material used. of each experiment. His beds of seedlings contain hundreds, often thousands, of individuals where other men are content with hundreds. Another element in his work is his prodigality of time. Experiments begun twenty years ago are actually still under way.

"In all that I have so far written. I have purposely kept to general statements applicable to Burbank's work as a whole. My readers might be more interested. perhaps, to have some illustrations of the application of various processes of making new sorts of things, some analytical account of the history of various specific 'new creations,' but considerations of space practically forbid this. Just a few briefly described examples must suffice. More than is generally imagined, perhaps. Burbank uses pure selection to get new things. From the famous golden orange coloured California poppy (Escholtial ) he has produced a fixed new crimson form by 
selection alone. That is, noticing, somewhere, sometime, an Escholtzia individual varying slightly redder, he promptly took possession of it, raised young poppies from its seeds, selected from among them those varying in a similar direction, raised new generations from them and so on until now he who wishes may have his California poppies of a strange glowing crimson for the price of a little package of seed. where formerly he was perforce content with the golden orange. For me the golden orange suffices, but that does not detract from my eager interest in the flower-painting methods of Mr. Burbank. Even more striking a result is his blue Slirley poppy, produced also solely by repeated selection from the crimson field poppy of Europe. "We have long had various shades of black and crimson and white poppies, but no shade of blue. Out of 200,000 seedlings I found one showing a faintest trace of sky blue and planted the seed from it, and got next year one pretty blue one out of many thousand, and now I have one almost pure blue.'

"But another brilliant new poppy was made in a different way. The pollen of Papaver pilosum, a butter-coloured poppy, was put on the pistils of the Bride, a common pure white variety of Papaver somniform (double), and in the progeny of this cross was got a firc-coloured single form. The character of singleness was common to the ancestors of both parents, the character of fire colour in the lineage of somifcrum only, although the red of the new form is brighter than ever before known in the somnifera series. Both characteristics were absent (or rather latent) in both parents. And yet the perturbing influence of the hybridisation brought to the fore again these ancestral characters. The foliage of this fire poppy is intermediate in type between that of the two parents.

"The history of the stoneless and seedless plum, now being slowly developed by Burbanks, shows an interesting combination of selection. hybridisation, and reselecting. Mr. Burbank found a plum in a small wild plum species with only a part of a stone. He crossed this wild species with the French prune; in the first generation he got most individuals with whole stones, some with parts of a stone, and even some with no stone. Through three generations he has now carried his line by steadily selecting, and the percentage of no-stone fruits is slowly increasing, while quality, beauty, and productiveness are also increasing at the same time.

"The plum-cot is the result of crossing the Japanese plum and the apricot. The plum-cot, however, has not yet become a fixed variety and may never be, as it tends to revert to the plum and apricot about equally, although with also a tendency to remain fixed, which tendency may be made permanent. 
"Most of Burbank's plums and prunes are the result of multiple crossings in which the Japanese plums have played an important part. Hundreds of thousands of seedlings have been grown and carefully worked over in the twenty years of experimenting with plums, and single trees have been made to carry as many as 600 varying seedling grafts. The Bartlett plum, cross of the bitter Chinese Simoni and the Delaware, itself a Simoni hybrid. has the exact fragrance and flavour of the Bartlett pear. The Climax, a successful shipping plum, is also a cross of the Simoni and the Japanese triflora. This Chinese Simoni produces almost no pollen, but few grains of it ever having been obtained. But these few grains have enabled Burbank to revolutionise the whole plum shipping industry. The sugar prune, which promises to supplant the French prune in California, is a selected product of a second or third generation variety of the Petite d'Agen, a somewhat variable French plum.

"Next in extent probably to Burbank's work with plums and prunes is his long and successful experimentation with berries. This has extended through twenty-five years of constant attention. has involved the use, in hybridisations, of forty different species of $R u b u s$, and has resulted in the origination of a score of new commercial varieties, mostly obtained through various hybridisations of dewberries, blackberries, and raspberries. Among these may specially be mentioned the Primus, a hybrid of the western dewberry ( $R$. ursinus) and the Siberian raspberry ( $R$. cratcgifolius), fixed in the first generation, which ripens its main crop before most of the standard varieties of raspberries and blackberries commence to bloom. In this Primus berry, we have the exceptional instance of a strong variation, due to hybridisation, breeding true from the time of its first appearance. It usually takes about six generations to fix a new variety, but like de Vries's evening primrose mutations, the Primus berry is a fixed new form from the time of its beginning. An interesting feature of Mr. Burbank's brief account, in his 'New Creations' catalogue of I894, of the berry experimentation, is a reproduction of a photograph showing 'a sample pile of brush, I2 $\mathrm{ft}$. wide, I4 ft. high, and $22 \mathrm{ft}$. long, containing 65,000 two- and three-year-old seedling berry bushes $(40,000$ blackberry $X$ raspberry hybrids and 25,000 Shaffer $X$ Gregg hybrids) all dug up with their crop of ripening berries. The photograph is introduced to give the reader some idea of the work necessary to produce a satisfactory new race of berries. "Of the 40,000 blackberry $X$ raspberry hybrids of this kind, "Phenomenal" is the only one now in existence. From the other 25,000 hybrids, two dozen bushes were reserved for further trial.' 
"An astonishing result of the hybridisation between the black walnut, Juglans nigra, used as the pistillate parent, and the California walnut, $J$. californica, staminate parent, are walnut trees which grow with such an amazing vigour and rapidity that they increase in size at least twice as fast as the combined growth of both parents. Many tremendous growers are got in the first generation, but in the second there are included some of the most rapidly growing trees, perhaps, in the world. This hybrid has clean-cut, glossy bright-green leaves from two to three feet long with a sweet odour like that of apples, but it produces few nuts. Curiously enough the result of hybridisation by using the pollen of nigra on pistils of californica produces in abundance large nuts of a quality superior to that possessed by either parent.

"The famous Shasta daisy is the result of a multiple crossing between an American and a European species of field daisy and then between these hybrids and a Japanese form. The fragrant calla. known as 'Fragrance,' is descended from a single individual found by Burbank while critically examining a block of Little Gem calla seedlings. He was surprised in this examination by a fragrance resembing that of violets or water-lilies; as he had long been seeking a fragrant calla, the individual giving this perfume was carefully hunted out. No farther selecting was done; this plant was the single ancestor of the fragrant new race.

"And so one might go on for pages, but with slight variations in detail all these pages would tell only the same story: the stimulating or inducing of variability by environmental influences and by hybridisations; the search after, and keen recognition of. promising special variations; the selection of the plants showing these variations; rearing new generations from them, repeated selection, and new hybridisations to eliminate this characteristic or introduce that, and on until a desirable combination is found. Then the careful fixing of this form or type by repeated selection through several generations.

"But an end must be made of this. Let us, in a paragraph, simply sum up the essential things in the scientific aspects of Burbank's work. No new revelations to science of an overturning character; but the revelation of the possibilities of accomplishment, based on general principles already known, by an unusual man. No new laws of evolution, but new facts, new data. new canons for special cases. No new principle or process to substitute for selection, but a new proof of the possibilities of the effectiveness of the old principle. No new categories of variations, but an illuminating demonstration of the possibilities of stimulating variability and of the reality of this general variability as the fundamental transforming factor. 
No ncw evidence either to help the Darwinian factors to their deatl1bed, or to strengthen their lease on life; for the 'man' factor in all the selecting phenomena in Burbank's gardens excludes all 'natural' factors. Here are some of Burbank's own words, touching these matters that scientific men are particularly interested in, in his work:

"All scientists have found that preconceived notions, dogmas, and all personal prejudice must be set aside, listening patiently, quietly, and reverently to the lessons one by one which mother nature has to teach, shedding light on that which before was a mystery, so that all who will may see and know.

" Crossing gives the raiser of new plants the only means of uniting the best qualities of each, but just as often the worst qualities of each are combined and transmitted, so that to be of any value it must be followed by rigid and persistent selection, and in crossing, as in budding and grafting, the affinities can only be demonstrated by actual test.

" "All wild plants of any species are under almost identical environments, having their energies taxed to the utmost in the fierce struggle for existence. Any great variation under such circumstances is not likely to occur, and is much more likely to be stamped out at once by its struggling competitors, unless the variation should be of special use in competition, in which case it will survive, and all others may be supplanted by it. Thus we see how new species are often produced by nature. but this is not her only mode. Crosses and hybrids are very often found growing wild where two somewhat similar species grow contiguous, and if the combination happens to be a useful one, as it often does, the new creation is encouraged by nature; then time and environment fix it, and man comes on the scene, perhaps ages later, and discovers it, and, not knowing all the facts, wonders where the connecting links have gone. It is botanically classified as a new species, which it is most certainly.

" In cultivated plants the life struggle is removed, and here we find variation almost the rule rather than the exception.

"Varieties are the product of fixed laws, never of chance, and with a knowledge of these laws we can improve the products of nature, by employing nature's forces, in ameliorating old and producing new species and varieties better adapted to our necessities and tastes. Better food, more sunshine, less arduous competition, will of themselves induce variation in individual plants which will be more or less transmitted to their seedlings, which, selected consecutively through a certain number of generations, will become permanent. Environment here exerts an influence as in all chemical. cosmical, and celestial movements. These small increments from 
environmental forces may produce a gradual or sudden change according to circumstances. The combustion of food liberates the moving force, environment guides it as it does the planets.

"When once the persistent type is broken up, old latent forces may be liberated and types buried in the dim past reappear. This, called atavism, is a concentration of ancestral forces-reverberating echoes-from varieties long since passed away, exhibiting themselves when from some cause, for instance crossing, present forces are in a state of antagonism, division, perturbation, or weakness. These echoes, if collected by crossing and selection, produce combinations of superlative importance and value." "

"Plate, L.. "Über die Bedeutung," etc., p. 220.

${ }^{8}$ See Koken, Ernst, "Palæontologie und Descendenzlehre," Ig02. Koken (Professor of Geology and Palæontology in the University Orthogenetic of Tübingen) is very explicit in the statements of his variation in palæontologr "Das Darwin'sche Prinzip der Selektion ist nicht das einzige, das. in Betracht kommt und es scheint nicht das wichtigste zu sein. Vielfach vermissen wir in der palæontologischen Geschichte den Hinweis auf ein Eingreifen des Kampfes ums Dasein und andererseits heben sich Richtungen der Entwickelung heraus. welche nicht in Beziehung zu einem Nutzen stehen, in einigen Fällen zu einer Schädigung der socialen Bedingungen führen."

"For an account of the facts of one such case, see Kellogg, "Is There Determinate Variation," Scicnce, N. S., Vol. XXIV. pp. 62I628 , 1906. In this paper the gradual but obvious change from

A case of ap- one dominant type of colour-pattern to another in parent determi- the leaf-eating beetle Diabrotica soror (on the campus. nate variation, of Stanford University. California) during the last. ten years, is shown by statistical variation studies. It is shown that such change is not explicable on a basis of intra-specific selection, nor can it be interpreted as a direct ontogenic reaction in each succeeding generation to changing climatic conditions. The case is believed to be an example of definitive orthogenetic variation.

Certain examples of presumable determinate variation have been recorded by Henslow ("The Origin of Species," Natural Scicnce, p. 259, 1894). "In 1847, Prof. J. Buckman sowed seed of wild parsnip in the garden of the Agricultural College, at Cirencester. The seedlings began to vary, but in the same way, though in different degrees. By selecting seed from the best rooted plants, the acquired 'somatic' characters of an enlarged root, glabrous leaves, etc., became fixed and hereditary; and 'The Student,' as he called 
it, having been 'improved' by Messrs. Sutton \& Sons, is still regarded as 'the best in the trade.' This is definite variation, according to Darwin's definition, for those weeded out did not differ from the selected, morphologically, except in degree, the variations towards improvement not being quite fast enough to entitle them to survive.

"M. Carrière raised the radish of cultivation, Raphanus sativus, L., from the wild species $R$. raphanistum, L., and moreover found that the turnip-rooted form resulted from growing it in a heavy soil, and the long-rooted one in a light soil.* Pliny records the same fact as practised in Greece in his day, saying that the 'male' (turnip form) could be produced from the 'female' (long form), by growing it in 'a cloggy soil.' Both forms are now, of course, hereditary by seed."

${ }^{10}$ Nägeli, C. von, "Mechanisch-physiologische Theorie der Abstammungslehre," I884.

${ }^{11}$ Korschinsky, S., "Heterogenesis und Evolution," Naturwiss. Wochenschrift, Vol. XIV, pp. 273-278, I899.

${ }^{12}$ Recently, Georg Pfeffer ("Die Entwicklung," I895) has proposed a theory of orthogenetic evolution not very different from the much earlier Nägelian one. Pfeffer postulates as Pfeffer's theory inherent in living matter a capacity for change and
of orthogenesis. of orthogenesis, for self-directing this change. The principle of change or progress he calls the conception of "developmental-screw" (Entwicklungsschraube), and for directing this progress the conception of "self-steering" (Selbststeuerung). Both these capacities of individualised living stuff are something over and beyond the mechanical and physico-chemical attributes of living matter. "On the contrary," says Pfeffer, "life consists of the capacity (more exactly the exercise of this capacity) of consciously permitting and consciously influencing (that is, actually producing) through physico-chemical phenomena changes in the matter or form of the fundamental life-stuff."

From this curious, though keen, critical, and constructive essay, I quote as follows:

"Der Begriff der Entwickelungsschraube deckt sich eigentlich völlig mit dem Begriff der Selbststeuerung der lebendigen Natur; ich halte aber mit gutem Grunde beide Ausdrücke aufrecht, weil sie einer verschiedenen Betrachtung entspringen, nämlich die Selbststeuerung der mechanischen, die Entwickelungsschraube der historischen, entwickelungsgeschichtlichen Betrachtungsweise; die Selbststenerung ist das Prinzip der Herstellung des Gleichgewichtes * This has been corroborated by M. Languet with the carrot. Soc. Roy. et Cent. d'Agricult., 2 d ser., Vol. II, 1846-7, p. 539. 
eines aus lebendigen Einheiten gebildeten Ganzen; die Entwickelungsschraube das Prinzip der veränderten Weiterführung dieser Gleichgewichtsverhältnisse in der Zeit. Also ist, ebenso wie die Selbststeuerung, auch die Entwickelungsschraube selbstthätig (pp. I2 and I3).

"Es ist hier nicht der Ort, die physikalischen wie die Unzahl der chemischen Eigenschaften der lebendigen Grundsubstanz zu erörtern; sie liegen freilich nicht auf der Hand, sind aber im Ganzen ziemlich leicht herzuleiten als das allen lebendigen protoplasmatischen Substanzen Gemeinsame. Es fällt aber Niemandem ein, bez. sollte Niemandem einfallen, die physikalischen und chemischen Eigenschaften der lebendigen Substanz als Lebens-Eigenschaften zu betrachten; vielmehr besteht das Leben in der Fähigkeit (bez. der Ausübung der Fähigkeit), die durch chemisch-physikalische Vorgänge an dem Stoff oder der Form-Ausprägung der Grundsubstanz bewirkten Veränderungen bewusst $z$ u erleiden und bewusst zu beeinflussen (bez. hervor zu bringen). Es hat also jeder körperliche Vorgang der lebendigen Substanz seinen von ihm untrennbaren Bewusstseinsvorgang; oder anders ausgedrücht: jeder Vorgang an lebendigen Wesen hat einen in chemisch-physikalische und einen anderen in Bewusstseins-Verhältnisse zerlegbaren Anteil. Beide sind Gegenstände wissenschaftlicher Betrachtung, dagegen entzieht sich die Art und Weise des Zusammenhanges zwischen beiden unserm Anschauungsvermögen, liegt also ausserhalb der naturwissenschaftlichen Betrachtung und ist damit als gegeben hinzunehmen" (p. I7).

A recent proposal of an orthogenetic theory of the general character of Nägeli's is that set out in O. F. Cook's "Aspects of Kinetic Evolution," Proc. Wash. Acad. Sci., Vol. VIII, pp. I97-403, I907.

${ }^{13}$ Eimer, Th., "Die Entstehung der Arten auf Grund von Vererbung erworbener Eigenschaften nach den Gesetzen organischen Wachsens." I, I888; trans. into English, as "Organic

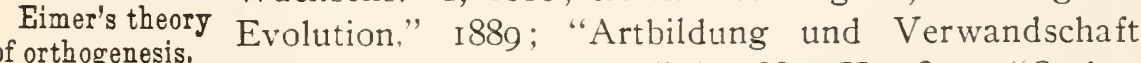
bei den Schmetterlingen," I, I889. II, I895; "Orthogenesis bei Schmetterlinge" (Part II of "Die Entstehung der Arten"), I898; "Orthogenesis," 3 Internat. Congress Zool., I895; trans. in English as "On Orthogenesis and the Impotence of Natural Selection in Species-Formation," I898. This address, and Eimer's other writings as well, are sadly marred by intemperate polemic and the indulgence of personal rancor. He deems himself and his views unfairly overlooked by biologists and seems to hold Weismann personally responsible for this. Apart from these unfortunate digressions his papers are extremely suggestive and logically and 
keenly composed. I believe that Eimer's work and theories should have more attention from students of evolution then they now get.

${ }^{14}$ Dean, Bashford. "Evolution in a Determinate Line, as Illustrated by the Egg-Cases of Chimæroid Fishes," Biol. Bull., Vol. Apparent deter-VII, pp. I05-II2, I904. In this paper the author minate evolution. expresses his belief that the conditions existing in the curious inter-related adaptations between eggs and egg-cases of the shark-like fish, Chimæra, can be explained only on the basis of determinate or orthogenetic modifications, in which modifications neither natural selection nor the Lamarckian factors of use and disuse can have played any part. The capsule or egg-case, although "only indirectly connected with the egg, i.e., as a secretion formed by the parent after the mechanism of heredity has already been established in the egg, nevertheless foresees with startling exactness the size and shape of the young fish when many months hence it comes to hatch out, and it provides a series of progressive multiplications adapted to the physical needs of the young. It is evident, accordingly, that if natural selection be adduced to explain the present phenomena it encounters difficulties more numerous and complex than in usual instances. In the latter cases selection concerns itself with variations which affect the progeny directly; but in the present case variations must have occurred in the lines both of the progeny and, indirectly, of its far less indifferent capsuleforming capabilities-with result that a succession of closely correlated stages in variation must have coincided in both distinct conceptions."

${ }_{15}$ Plate, L., “Über die Bedeutung," etc., p. I9o ff.

${ }^{16}$ Rosa. Daniel, "La Riduzione Progressiva della Variabilita i suoi Rapporti coll' Estinzione e coll' Origine della Specie." I899. Author believes that in animal life there is a gradual progressive reduction of variation (or modification) necessitated by the wellknown fact that highly specialised forms have distinctly fewer lines of modification, $i$. e e specialisation, left open to them than generalised forms; and that all groups of animals are of the nature of series of more and more specialised forms. He bases this belief, as far as facts go, on the well-known cases of the dying out of specialised species (Irish stag) and specialised groups (Cretaceous reptiles), and on the alleged facts (which the author devotes many pages to trying to show) that all present-day principal groups of animals are related to each other solely by derivation from common very old and generalised ancestors. If there is less modification possible, then there occurs actually less and less variability, and the actually occurring variations will be only along certain lines, i. $\mathcal{c}$. there will be in this limited variability an actual basis for ortho- 
genesis. On the double basis of progressively less variation and of the thus produced orthogenesis the author sees a factor in phylogeny (organic evolution) which works, to some degree, independently of natural selection or of Lamarckian factors. Rosa thinks he has thus contributed to biology one of the always sought-for "unknown factors in evolution."

${ }^{17}$ In an interesting paper by Snodgrass, "The Relation of the Food to the Size and Shape of the Bill in the Galapagos Genus Geospiza,"

Snodgrass's Auk, Vol. XIX, pp. 367-381, 1902, detailing the exobservations on amination of the stomach contents of over 200 indibills of Gala- viduals, representing I3 species and sub-species (taken pagos birds, from several of the Galapagos Islands) of the peculiar Galapagos Fringillid genus, Geospiza, remarkable for the great differences in size and shape of bill characterising the various species and sub-species, the author states that all the "evidence seems to be in favour of the general conclusion that there is no correlation between the food and the size and shape of the bill." The following five propositions were established: (I) The same species at different localities may feed on different seeds; (2) different species at the same locality may feed on the same kinds of seeds; (3) different species at different localities may feed on the same kinds of seeds; (4) different species at the same or at different localities may feed on different seeds; and (5) birds with small bills eat only small seeds; birds with large bills eat both small and large seeds. The seeds taken from the stomachs varied in size from seeds of I cubic millimetre up to those $15 \mathrm{~mm}$. long by $10 \mathrm{~mm}$. thick. The bill of the different species and sub-species of Geospiza. varies from that of $G$. scandens scandens, I3 $\mathrm{mm}$. long by $7 \mathrm{~mm}$. high at base, to that of G. pachyrhyncha, I7 $\mathrm{mm}$. long by $20 \mathrm{~mm}$. high at base.

${ }^{18}$ Eimer, Th., "Orthogenesis der Schmetterlinge," IS97.

${ }^{19}$ Cope. E. D., "The Method of Creation of Organic Types," Proc. Amer. Phil. Soc., December, I87i.

${ }^{20}$ Cope, E. D., "The Energy of Life Evolution," Pop. Sci. Mo., Vol. XXVII, pp. 789-800, October, I885: "Primary Factors of Organic Evolution," I 896.

${ }^{21}$ "Palæontologists, as a rule,- -and Prof. Cope is one of them,are so profoundly impressed by the adaptive nature of the eroluCope's belief tionary process and by the definitiveness of its direcin orthogenetic tion. that they cannot regard the restraining or ovolution. selective action of the environment as enough to keep the breed true. They are so accustomed to seeing mutation after mutation, generation after generation, developing in apparent obedience to obvious physico-chemical or mechanical conditions, that 
they incline to regard these conditions as causes. And if it be suggested to them that the results they see may have been achieved by the selection of adaptive variations from among a number of promiscuous variations that are not adaptive, they ask why it is that they do not find evidence of these numerous known adaptive variations in the organs, when one would suppose that, on any hypothesis, except that of definite variation, such forms must have been the more abundant of the two. It is useless to reply to them that the known adaptive variations in each generation were killed off when young, and so. even if fossilised, are practically undistinguishable; because they will reply with abundant proof that the adaptive characters chiefly appear in the adult stages of the organism, possibly only in its senile stages, and so are incapable of coming under the action of natural selection during the early undifferentiated stages. How the conversation might continue does not much matter, for it is obvious that it has reached a point beyond which all must be speculation. The facts on which the palrontologist relies, the facts that Prof. Cope adduces with such wealth of knowledge, are strong presumptive evidence in favour of his second thesis, but they are not proof." (Bather, F. A., Natural Science, Vol. X, pp. 40-4I, I897.)

Prof. Scott, another American palæontologist, discusses the question of variation in an interesting paper in the American Journal of Science, Vol. XLVIII, pp. 335-374. I894. The great point made by Prof. Scott is the clear distinction between individual and phylogenetic variation. Individual variation is irregular and not fixed, while "phylogenetic variation," or mutation (in the sense of * Waagen) which is distinguished from individual variation, not by any character of quantity or quality, but by pursuing a determinate direction and thus, under control of natural selection, leading to the formation of new species. "Remembering that the significant fact in the history of a group is not so much the character of its variations at any one stage, as the gradually shifting positions successively occupied by the normal or centre of stability, we find that any mammalian series at all complete, such as that of the horses, is remarkably continuous, and that the progress of discovery is steadily filling up what few gaps remain. So closely do successive stages follow upon one another that it is sometimes extremely

* The term "mutation" was first used in biology, probably, by Waagen, I869, in a paper on the phylogeny of an ammonite. In this first use of the word its meaning was a change or modification accomplished during a considerable historic period. Indeed, it had much the meaning of evolution or descent as we use these terms nowadays. 
difficult to arrange them all in order and to distinguish clearly those members which belong in the main line of descent, and those which represent incipient branches. Some phylogenies actually suffer from an embarrassment of riches."

${ }^{22}$ Whitman, C. O., "The Problem of the Origin of Species," Proceedings of Congress of Arts and Science. Universal Exposition. St.

Whitman's Louis, Vol. V, pp. 41-58, 1906. In this paper Whitbelief in deter- man takes strong ground for orthogenesis and recites minate variation, in detail a number of interesting facts touching the evolution of pattern in pigeons to illustrate his belief. Touching the criticism of orthogenesis, that it involves a teleologic element in its make-up, Whitman says (p. 5): "I take exception here only to the implication that a definite variation-tendency must be considered to be teleologic because it is not 'orderless.' I venture to assert that variation is sometimes orderly, and at other times rather disorderly, and that the one is just as free from teleology as the other. In our aversion to the old teleology so effectually banished from science by Darwin we should not forget that the world is full of order, the inorganic no less than the organic. Indeed, what is the whole development of an organism if not strictly and marvellously orderly? Is not every stage, from the primordial germ onward, and the whole sequence of stages, rigidly orthogenetic? If variations are deviations in the directions of the developmental processes, what wonder is there if in some directions there is less resistance to variation than in others? What wonder if the organism is so balanced as to permit of both unifarious and multifarious variations? If a developmental process may run on throughout life (c. $g$., the life-long multiplication of the surface-pores of the lateral-line system in Amia), what wonder if we find the whole species gravitating slowly in one or a few directions? And if we find large groups of species. all affected by a light variation, moving in the same general direction, are we compelled to regard such 'a definite variation-tendency' as teleological, and hence out of the pale of science? If a designer sets limits to variation in order to reach a definite end, the direction of events is teleological; but if organisation and the laws of development exclude some lines of variation and favour others, there is certainly nothing supernatural in this. and nothing which is incompatible with natural selection. Natural selection may enter at any stage of orthogenetic variation, preserve and modify in various directions the results over which it may have had no previous control."

${ }^{23}$ Cunningham, an English neo-Lamarckian, expresses ("Origin of Species Among Flatfishes." Natural Science, Vol. VI, p. 239, I895) his belief in orthogenesis as follows: 
"The only general view, as it seems to me, which can be held concerning the structural diversity of the animal kingdom, is to regard it as resultant of two more or less opposing Cunningham general tendencies. On the one hand, there is uniand orthogenesis, versal evidence of a tendency to definite variation, or growth in different directions, leading to manifold variety of regular definite symmetrical forms. This tendency can only be regarded as internal to the organism, as connected with a tendency to growth and multiplication inherent in organic units. On the other hand, there is the molding, limiting, constructing action of the external forces of the environment resulting in more or less complete adaptation. Whatever be the process of adaptation, whether Darwinian selection or Lamarckian modification, adaptive structural combinations are mechanisms each working with the particular result which is important to the feeding, living, and breeding of the organism. Whatever the causes of non-adaptive variation, the resulting structural features are the regular genetic forms and characters which the multitude of different organic forms present in such marvellous diversity. No one who, like Weismann, ignores everything except adaptation, or who, like Bateson, regards the study of adaptations as barren and profitless, can hope to produce a consistent and comprehensive theory of organic evolution."

${ }^{24}$ Delage, Yves, "L’Hérédité," 2d ed. p. 849, and others, 1903.

${ }^{25}$ Jaeckel, O., "Über verschiedene Wege phylogenetischer Entwicklung," I902. 
OTHER THEORIES OF SPECIES-FORMING AND DESCENT (CONTINUED): ALTERNATIVE THEORIES (CONTINUED).

Heterogenesis.-Under the name heterogenesis we have to consider a theory of species-forming which is more popularly and widely known under another name, viz., the mutations theory. This theory is commonly associated with the name of de Vries, the Amsterdam botanist. But this general conception of species-forming on a basis of the occurrence of occasional, sudden, fixed, and often considerable changes or variations in the offspring of a plant or animal, is a conception not of course new with de Vries, but one variously expressed by numerous biologists from Darwin's time on, especially by von Kölliker, Galton, Dall, Bateson, Emery; Scott, and Korschinsky. It is, however, chiefly due to the patient. persistent, well-planned, and extensive experiments and observations of de Vries that this theory of species-forming by heterogenesis, or as called by de Vries, by mutations, has recently received so much renewed attention. With the observations of de Vries on the breeding of certain plant species, notably certain Enotheras (evening primroses), there have been much associated in recent popular scientific literature accounts of the earlier observations of Gregor Mendel, ${ }^{1}$ an Augustinian monk, who recorded, in 1865 , in an obscure journal, some very valuable observations and logical conclusions concerning the phenomena of heredity in certain other plants (especially garden peas). Reference should also be made, in this con- 
nection, to observations and experiments carried on nearly simultaneously with those of de Vries by Correns ${ }^{2}$ and Tschermak. $^{3}$ As a matter of fact the data on which de Vries bases his theory of species-forming by heterogenesis are, in part, nearly identical with those obtained by Mendel, Tschermak, and Correns, which, however, is concerned primarily with explaining the "laws" of heredity.

The meaning of heterogenesis in connection with speciesforming and descent is essentially this: whereas by the Darwinian theory species are transformed slowly and by slight changes in at first one or two or a few and only later in more parts, and all new species are derived from the old ones (which usually disappear as the new ones appear) by the gradual selection of the advantageous ones among the regular slight, fluctuating, individual variations (known commonly as Darwinian variations and which mostly occur according to the law of error), by the theory of heterogenesis new species appear suddenly, not by a selective choosing among the slight fluctuating Darwinian variations, but independently of selection, and largely independently of the so-called Darwinian variations, by the appearance in fixed definitive form of several to many slight to considerable variations, which give the new species definite characteristics differentiating it often in many particulars from the old species, which differentiating characteristics are fully and faithfully transmitted to the succeeding generations of individuals derived from this suddenly born new species.

In some theories or views of heterogenesis the suddenly. appearing new variations-and none of these theories gives a satisfactory explanation of the cause of these Discontinnous sudden variations-which give rise to new
ariation. species, are those large, sometimes monstrous, variations known as "sports," "monsters," etc. ; or, in Bateson's words, are "discontinuous variations," i.e., considerable variations not connected by a continuous series of gradations. 
with the parent type of the variable organ or individual. Darwinians have always been interested in such variations, for if they do occur in any considerable numbers they might offer a possible solution of that difficulty in the selection theory of explaining the origin of new structures and the needed degree of size and development sufficient to make these beginnings useful and hence available as handles for natural selection. But it has long been recognised that such sports or discontinuous variations are too few and occur too rarely to furnish the basis for a comprehensive theory of species-forming. Like the extremes of individuals in the series of fluctuating variations, their characters would be lost or swamped by crossing. Darwin himself made as full a list of such sports as any post-Darwinian writer, excepting Bateson, has been able to do, and he recognised the fact that certain species, or races at least, of domesticated animals and cultivated plants undoubtedly had their beginnings in these sports. His examples of such discontinuous or saltatory evolution as the Ancon and Mauchamp sheep, the Paraguay cattle, ${ }^{4}$ etc., are the classic examples in animal evolution, and to this day nearly the only ones! Bateson ${ }^{5}$ has, to be sure, gathered together in his "Materials for the Study of Variation" a much larger list of sports or discontinuous variations than Darwin included in his knowledge (it should be borne in mind in referring to Bateson's list that several, probably, incleed, many of his alleged examples are cases of teratogenic regeneration) - but he has been able to add almost no new examples of the origin of a new species from such discontinuous variations. A few cases are known of the inheritance through a number of generations of suddenly appearing sports or discontinuous variations in human beings (cases of polydactyly, etc.) and cats. (Kennel's stump-tailed cat, which produced in six litters four stump-tailed, twelve tailless, and twelve normal young, is an example of several similar cases which have. 
been recorded.) Species-forming by sports and discontinuous variations is obviously no theory to presume to offer itself as a species-forming substitute for natural selection. But the de Vriesian mutations theory, the most recent development of the heterogenesis conception, has rehabilitated this conception to such an extent that a number of biologists see in it an actually satisfactory substitute for the natural selection theory. Before explaining the theory of de Vries let us first note two or three other prior formulations of theories of heterogenesis, one at least being nearly identical with that of de Vries.

In I864 the great zoologist von Kölliker, ${ }^{6}$ in a paper under the title "Über die darwinische Schöpfungstheorie," took positive ground against the adequacy oractuality Von Rölliker's of natural selection as a species-forming factor,
suggestion.

and proposed a theory of "heterogene Erzensung" (heterogenesis) which he formulated, however, only in most general terms. He said that "under the influence of a general law of development (evolution) organisms bring forth other kinds differing from them out of the germs produced by them." He included in his general theory of heterogenesis a basic plan of progressive evolution. Such a conception has in it too much autogenic orthogenesis ; it is too redolent of teleology for present-day biology. The variations, too, which are to serve as beginnings of new species are those too rare ones which we have referred to as sports and discontinuous variations.

The American naturalist, Dall, ${ }^{7}$ in a paper written in I877, expresses his conviction that sudden changes of species-forming character do occur, and as-

Dall's belief in sudden spe. cies-change. belong to different genera." That sudden leaps may be due to the gradual accumulation of minute differences he 
exemplifies as follows: "In a sloping gutter of a paved street not too cleanly swept every one will notice on a sudden shower how small particles of earth and other materials will sometimes act as a dam, producing a puddle which, relieved by partial draining, may for a time remain in statu quo. A time comes, however, when the gradually accumulated pressure suddenly sweeps the dam before it for a short distance, until another similar one is formed, the pool again appears for a time to remain unchanged, and so on indefinitely. Now the modern idea of a species may be stated to be a greater or lesser number of similar individual organisms in which for the time being the majority of characters are in a condition of more or less stable equilibrium, and which have the power to transmit these characters to their progeny with a tendency, to maintain this equilibrium. This tendency may be, in some cases, sufficiently strong to resist for a considerable period the changes which a gradual modification of the environment may tend to bring about. When the latter has reached a pitch which renders the resistance no longer effectual, it is conceivable that a sudden change may take place in the arrangement of the constitution of the organism, adapting it once more to its surroundings, when the tendency to equilibrium may reassert itself in the minor characteristics, and they may, as it were, crystallise once more in a form not dissimilar in generic type. If among a certain assemblage of individuals constituting a species, the tendency to maintain the specific equilibrium be (as it should be a priori) transmitted to the progeny in different degrees of intensity, a gradual separation might take place between those with a stronger tendency to equilibrium and those with less. Here natural selection would come in. Those yielding as above to the pressure of the environment would necessarily become better adapted to it (or perish) and with their changed generic structure might be able to persist. On the other hand, those 
with the broader base, so to speak, with the inherited tendency to remain unshaken by the modifications of the environment, may be conceived as through this tendency to be and to remain less injuriously affected by adverse circumstances, and consequently might still endure. In short, natural selection in the one case would find its fulcrum in the tendency to easy adjustment of characters; and in the other case in the inherited persistency in equilibrium rendering its possessor more or less indifferent to the injurious elements of the environment. The intermediate individuals by the hypothesis would be those least-fitted to persist in any case and hence liable to be rapidly eliminated. Then we should have parallel series of species in two or even more genera existing simultaneously."

Francis Galton, the great student of heredity and, in most of his belief a thorough Darwinian, nevertheless held it to be probable that evolution might proceed not only Galton's belief by minute steps but that decisive sudden changes in discontinnous steps.

of the type may occur. "That the steps may be small and that they must be small are very different views; it is only to the latter that I object, and only when the indefinite word 'small' is used in the sense of 'barely discernible' or as small compared with such large sports as are known to have been the origin of new races." ${ }^{8}$ And his familiar analogy of organic stability to that of the polygon $^{\circ}$ with unequal sides, whose stability or fixity depends upon which of these sides it may be resting on, expresses well the basic idea in heterogenesis or mutation by small but definitive and fairly stable changes. Galton also believed in the stability or fixity of sports; not that all transmit their character to their young but that many do and thus give rise to new types.

Emery, ${ }^{10}$ in his suggestive paper called "Gedanken zur Descendenz- und Vererbungstheorie," expresses his belief in the importance in species-forming of what he calls "pri- 
mary variations," which are large and sudden as contrasted with "secondary variations," which are the usual small,

Emery's theory of "primary variations." fluctuating or so-called Darwinian variations. Emery bases his belief on the few cases like the Ancon sheep and the inherited six-fingeredness of men, and also on an argument drawn from the difficulty of explaining by the natural selection theory various existing conditions such as sexual polymorphism, and numerous cases of extremely complex structural and physiological specialisation. But there is little that is convincing in Emery's presentation.

A later exponent of heterogenesis of a different kind, and a more sharply-spoken antagonist of the selection theory,

Korschinsky's theory of heterogenesis. much more nearly anticipates de Vries's mutation theory. Indeed this biologist, the Russian botanist Korschinsky, in his championship of heterogenesis goes much beyond de Vries in his denial of the influence of selection in species-forming and descent. De Tries, as we shall see, admits natural selection to be a factor, and perhaps a large one in the determination of descent, of organic evolution, but holds it to be wholly a restraining and cutting-back factor, not at all a formative one. Korschinsky says plainly that the struggle for existence and selection have either no influence in species-forming and descent, or, if any, a hindering and antagonising influence, a retarding and nullifying influence. Korschinsky has published his theory in three papers, one a large work in Russian which I have not seen, the others shorter papers ${ }^{11}$ in German which are of the nature of vorlaïfige Mitteilungen. In these papers he formulates clearly and positively a theory of leterogenesis or species-forming by "mutations" and attacks sharply and positively the natural selection theory. A concise statement of his theory and at the same time of his position with regard to the selection theory is given by him in a table of two columns in which the contrast between 
the two theories is graphically shown. I translate here this "parallel columns" statement in full:

ACCORDING TO THE TRANSMUTATION THEORY.

I. To all organioms there belongs a capacity for variation which is called into play partly through inner, partly through outer causes, through use and disuse, etc. This capacity for variation regularly finds its expression in the appearance of slight and unnoticeable individual differences.

2. As a result of this struggle for existence and selection, those individual variations which prove themselves useful become fixed and accumulated, while the non-useful ones disappear. All characteristics and peculiarities of a species must, as a result of a prolonged selection. stand in harmony with the outer conditions, and be useful to the organism.

3. Through prolonged selection and accumulation of characteristics all species undergo a persistent change, whereby they are gradually transformed into new species without, however, sacrificing their normal physiological relations.

4. This process can take place everywhere and under all circumstances. The harder the onter conditions and the sharper the struggle for existence, the more energetically selection works, and therewith the quick-
ACCORDING TO THE THEORY OF HETEROGENESIS.

I. To all organisms there belongs a capacity for variation, which is a fundamental inner peculiarity independent of outer conditions, and which remains usually in latent condition, retained by heredity, but which now and then finds its expression in sudden changes.

2. These sudden changes can, under favourable conditions, be the beginnings of persistent races. These new characteristics, having appeared independently of outer conditions, are sometimes useful to the organism. but they may also stand in no harmony witl outer conditions.

3. All once-formed species remain unchanged, although new forms occasionally split off from them by heterogenesis. Such newly-arisen forms have, as the result of a disturbed heredity, a deranged constitution, which reveals itself in a lessened fertility and often in a generally weakened condition of the organism. The new forms, becoming constant races, gradually recover their constitution.

4. The origin of new forms can, however, occur only under favourable conditions of existence for the species, and the more favourable these conditions, that is, the less severe the struggle for existence, the 
er the development of new forms.

5. The chief requisite for evolution is, therefore, the struggle for existence and the selection which results from it.

6. If there were no struggle for existence, no selection, no survival of the strongest, there would be no evolution and no specialisation, for adapted species would have no advantage over unadapted ones, and as a result of crossing with the latter, they would sacrifice their useful characteristics.

7. The so-called advance in nature or the perfecting of organisms, is nothing else than a more complex, more complete adaptation to outer conditions, and it is reached in a purely mechanical way through selection and the accumulation of characteristics useful under the existent outer conditions. more energetically can evolution go on. New forms do not arise under hard external conditions, or if any do, they go quickly to ground.

5. The struggle for existence, and the selection that goes hand in hand with it, constitute a factor which limits new forms and hinders further variation and is, therefore, in no way favourable to the origin of new forms. It is a factor inimical to evolution.

6. If there were no struggle for existence, there would be no killing out of newly arising or already arisen forms. The world of organisms could then grow to a mighty tree, whose branches could all persist in blossoming condition, and the most aberrant, now isolated, species would be connected with all others through intermediate forms.

7. The adaptation $\mathrm{wh} \mathrm{ich}$ comes to exist through the struggle for existence is not at all identical with an advance, for higher, more specialised (vollkommcncre) forms are by no means always better adapted to outer conditions than the lower ones. One cannot explain the evolution of organisms in a purely mechanical way. In order to explain the origin of higher forms out of lower it is necessary to admit a special tendency, in organisms, for advance, which is nearly related to, or identical with the tendency to vary, and which compels organisms toward perfectness as far as external conditions allow.

The theory of heterogenesis as formulated by Korschinsky (and also as held by de Vries, as we shall see) is not neces- 
sarily a theory of sudden large changes or variations, although it is of sudden and fixed ones. It is not based on any belief that sports or large variations are any more numerous, nor of any more worth as the beginnings of new species, than now generally recognised, but it assumes sudden radical changes in the organism which, if not visibly large as regards obvious quantitative conditions, are large or at least comprehensive as regards qualitative conditions. The mutation or variation assumed by the theory of heterogenesis affects many organs and parts, structurally and physiologically; it produces a radical change throughout the organism. And this change is the result of an influence wholly intrinsic, inherent, and has no reference to external conditions, except in that the stimulus for it may come partly or chiefly from specially favourable conditions of nutrition. This change is at once definitive and fixed: it is transmitted unimpaired to the offspring of the organism showing the mutation, only the capacity for the production of offspring, $i$. $c$., the reproductive fertility, is often weakened.

Korschinsky's theory and declarations are not based on any very large amount of personal experimentation and observation-at least his references to new facts are few and meagre. He gives a short list of old and more or less familiar together with a few new examples of heterogenesis but he does not lend the theory of heterogenesis very much in the way of authority, except in so far as the evidently positive and clear conviction on the part of a biologist of experience and reputable standing of the necessity and truth of such a theory is authority. Korschinsky's conviction is probably based on much observation and experience besides that which he definitely catalogued, but what is needed to carry conviction to others is direct reference to proved, and where possible verifiable, facts of observation and experiment.

The supplying of this demand, to a degree which will 
appear to various people insufficient or sufficient according to their respective ideas of what is needed in

$D_{e}$ Vries and the way of fact material for the satisfactory the mutations theory. founding of a theory, it is the special virtue of de Vries to have attempted on behalf of heterogenesis.

De Vries ${ }^{12}$ introduces his now classic two-volume presentation of his views on evolution and species-forming ("Die Mutationstheorie," Ig0I-I903) with the following paragraph :

"Als Mutationstheorie bezeichne ich den Satz, dass die Eigenschaften der Organismen aus scharf von einander unterschiedenen Einheiten aufgebaut sind. Diese Einheiten können zu Gruppen verbunden sein, und in verwandten Arten kehren dieselben Einheiten und Gruppen wieder. Übergänge, wie sie uns die äusseren Formen der Pflanzen und Thiere so zahlreich darbieten, giebt es aber zwischen diesen Einheiten ebensowenig, wie zwischen den Molekülen der Chemie." And again in the first paragraph of the preface to his book "Species and Varieties" ${ }^{13}$ (an edited transcription of his American lectures on species-forming, delivered in California in I904) he says: ". . . but the way in which one species originates from another has not been adequately explained. The current belief assumes that species are slowly changed into new types. In contradiction to this conception the theory of mutation assumes that new species and varieties are produced from existing forms by sudden leaps. The parent-type itself remains unchanged throughout this process, and may repeatedly give birth to new forms. These may arise simultaneously and in groups, or separately at more or less widely distributed periods."

Obviously there is no ambiguity here as to the relation of species-forming by mutation to species-forming by gradual modification through selection or fluctuating variations. In the words of de Vries: "Species have not arisen 
through gradual selection continued for hundreds or thousands of years, but by jumps (stufcnwcise) through sudden, though small, transformations. In contrast with variations which are changes in a linear direction the transformations. to be called mutations constitute divergence in new directions. They take place, so far as experience goes, without definite direction." $*$ And even if transition forms exist between the species produced by mutations, they are no evidence against the mutations, "for," says de Vries, "the transitions. do not appear before the new species, at most only simultaneously with this, and generally only after this is already in existence. The transitions are therefore no intermediates or preparations for the appearance of the new forms. The origin takes place, not through them, but wholly independently of them." 15

Too often de Vries's theory is said not to be alternative with Darwin's, but auxiliary to it. As regards the formation of new species, the two theories are directly

De Vries's in opposition. But as regards the general theory in opposition to course of organic evolution (which is another Darwin's as con- matter) the mutations theory is not in contracerns speciesforming.

diction to the theory of descent through selection. De Vries himself says: "Notwithstanding all these apparently unsurmountable difficulties, Darwin discovered the great principle which rules the evolution of organisms. It is the principle of natural selection. It is the sifting out of all organisms of minor worth through the struggle for life. It is only a sieve, and not a force of nature, no direct cause of improvement, as many of Darwin's adversaries, and unfortunately many of his followers also, have so often asserted. It is only a sieve, which decides which is to live, and what is to die. But evolutionary lines are of great length, and the evolution of a flower or of an insectivorous plant is a way with many side-paths. It is the sieve that keeps evolution on the main line, killing 
all or nearly all that try to go in other directions. By this means natural selection is the one directing cause of the broad lines of evolution." "

While de Vries admits that recorded mutations are few; "mutations under observation are as yet very rare; enough to indicate the possible and most probable ways but no more:" ${ }^{17}$ yet he strongly maintains that there is no scientific proof of the origin of species in any other way than by mutation and that there is such proof of their actual mutational origin. He says: "I intend to give a review of the facts obtained from plants which go to prove the assertion that species and varieties have originated by mutation and are, at present, not known to originate in another way."

But in any consideration of de Vries's work and theories, one must have clearly in mind the distinctive meaning which de Vries attaches to the word species. However little biologists agree on any absolute definition of species, the term nevertheless is consistently used to refer to differentiated organic types between any two of which there is considerable obvious describable difference, either qualitative or quantitative. If two types of such obvious difference in one or several characteristics (usually external or at least externally noticeable differences are the ones used) are connected by a series of connecting gradatory forms existing either in the same territory or in other regions, the two forms are not referred to as distinct species but as varieties; at least the form at one end of the series is called a variety of the form at the other end. But de Vries's species and varieties are of different stuff. Specific distinctions with him are based on differences in aggregation of the elementary units, the Einheiten, that go to compose the specific types. "Species is a word," says de Vries, "which always has had a double meaning. One of them is the systematic species, which is the unit of our system. But these units are not at all indivisible. Long ago Lin- 
næus knew them to be compound ideas in a great number of instances, and increasing knowledge has shown that the same rule prevails in other instances. To-day the vast majority of the old systematic species are known to consist of minor units. These minor entities are called varieties in systematic works. However, there are many objections to this usage. First, the term variety is applied in horticulture and agriculture to things so widely divergent as to convey no clear idea at all. Secondly, the subdivisions of species are by no means all of the same nature, and the systematic varieties include units the real value of which is widely different in different cases. Some of these varieties are in reality as good as species, and have been 'elevated,' as it is called, by some writers, to this rank. This conception of the elementary species would be quite justifiable, and would at once get rid of all difficulties, were it not for one practical obstacle. The number of the species in all genera would be doubled and tripled, and as these numbers are already cumbersome in many cases, the distinction of the native species of any given country would lose most of its charm and interest.

"In order to meet this difficulty we must recognise two sorts of species. The systematic species are the practical units of the systematists and florists, and all friends of wild nature should do their utmost to preserve them as Linnæus has proposed them. These units, however, are not really existing entities; they have as little claim to be regarded as such as the genera and families have. The real units are the elementary species; their limits often apparently overlap and can only in rare cases be determined on the sole ground of field-observations. Pedigree-culture is the method required and any form which remains constant and distinct from its allies in the garden is to be considered as an elementary species." "1s

With regard to varieties de Vries has the following to 
say: "Linnaus himself knew that in some cases all subdivisions of a species are of equal rank, together constituting the group called species. No one of them outranks the others; it is not a species with varieties, but a group consisting only of varieties. A closer inquiry into the cases treated in this manner by the great master of systematic science shows that here his varieties were exactly what we now call elementary species.

"In other cases the varieties are of a derivative nature. The species constitutes a type that is pure in a race which ordinarily is still growing somewhere, though in some cases it may have died out. From this type the varieties are derived, and the way of this derivation is usually quite manifest to the botanist. It is ordinarily by the disappearance of some superficial character that a variety is distinguished from its species, as by the lack of colour in the flowers, of hairs on stems and foliage, of the spines and thorns, etc. Such varieties are, strictly speaking, not to be treated in the same way as elementary species, though they often are. We shall designate them by the term of 'retrograde varieties,' which clearly indicates the nature of their relationship to the species from which they are assumed to have sprung. In order to lay more stress on the contrast between elementary species and retrograde varieties, it should be stated at once, that the first are considered to have originated from their parent-form in a progressive way. They have succeeded in attaining something quite new for themselves, while retrograde varieties have only thrown off some peculiarity, previously acquired by their ancestors." 19

With regard to the facts and general evidence ${ }^{20}$ on which

The facts at basis of de Vries's theory. de Vries bases his beliefs and theory a few words, too few, I regret, must suffice. Like Darwin, de Vries only came to the full publication of his theory after many years of assiduous obser- 
vation, of persistent compilation of other men's observing, and careful weighing and consideration of the data in hand. In de Vries's case too there was added a large amount of experimental testing of his conclusions. This experimental study of the species-forming problem de Vries and his followers rather seem to claim as a distinctively new part of the basis for the mutations theory, but as a matter of fact Darwin himself, in much less degree perhaps, and in somewhat different manner, appealed to experiment to test many of his conclusions. The actual forming of new species by selection could not be experimentally tested or proven by Darwin. Whether biologists are ready to accept de Vries's pedigree-culture work and results as of the same nature of rigid experimental test and proof as there exists in experimentation in chemistry and static physics (for that is the claim for the new "experimental method" in biology) remains, perhaps, a moot point. De Vries's general statement of the character and the amount of the evidence on which he rests his belief in the formation of species by mutation is contained in the following paragraphs from his book "Species and Varieties" (p. 22).

"Mutations are occurring from time to time in the wild state as well as in horticulture and agriculture. A selection of the most interesting instances will be given later. But in all such cases the experimental proof is wanting. The observations, as a rule, only began when the mutation made its appearance. A more or less vague remembrance about the previous state of the plants in question might be available, though even this is generally absent. But on doubtful points concerning possible crosses or possible introduction of foreign strains, mere recollection is insufficient. The fact of the mutation may be very probable, but the full proof is, of course, wanting. Such is the case with the mutative origin of Xanthium commune Wootoni from New Mexico and of Enothera biennis cruciata from Holland. 
The same doubt exists as to the origin of the Capsella Heegeri of Solms-Laubach, and of the oldest recorded mutation, that of Chelidonium laciniatum in Heidelberg about i600."

Next, after introducing the necessity of experimental proof and explaining how one must go to work to acquire such proof he refers to his own well-known work with Lamarck's evening primrose as follows (pp. 26-29):

"Complying with these conditions, the origin of species may be seen as easily as any other phenomenon. It is only necessary to have a plant in a mutable condiThe work with tion. Not all species are in such a state at Lamarck's even- present, and therefore I have begun by ascer-
ing primrose;

taining which were stable and which were not. These attempts, of course, had to be made in the experimental garden, and large quantities of seed had to be procured and sown. Cultivated plants, of course, had only a small chance to exhibit new qualities, as they have been so strictly controlled during so many years. Moreover their purity of origin is in many cases doubtful. Among the wild plants only those could be expected to reward the investigator which were of easy cultivation. For this reason I have limited myself to the trial of wild plants of Holland, and have had the good fortune to find among them at least one species in a state of mutability. It was not really a native plant, but one probably introduced from America or at least belonging to an American genus. It was the great evening-primrose or the primrose of Lamarck. A strain of this beautiful species is growing on an abandoned field in the vicinity of Hilverstim, at a short distance from Amsterdam. Here it has escaped from a park, and multiplied. In doing so it has produced, and is still producing, quite a number of new types, some of which may be considered as retrograde varietieș, while others evidently are of the nature of progressive elementary species. 
"This interesting plant has afforded me the means of observing directly how new species originate, and of studying the laws of these changes. My researches have followed a double line of inquiry. On one side, I have limited myself to direct field observations, and to trials of seed, collected from the wild plants in their native locality. Obviously the mutations are decided within the seed, and the culture of young plants from them had no other aim than that of ascertaining what had occurred in the field. But then the many chances of destruction that threaten young plants in a wild state could be avoided in the garden, where environmental factors can be controlled.

"My second line of inquiry was an experimental repetition of the phenomena which were only partly discerned at the native locality. It was not my aim to intrude into the process, nor to try to bring out new features. My only object was to submit to the precepts just given concerning pure treatment, individual seed-gathering, exclusion of crosses, and accurate recording of all the facts. The result has been a pedigree which now permits of stating the relation between all the descendants of my original introduced plant. This pedigree at once exhibits the laws followed by the mutating species. The main fact is, that it does not change itself gradually, but remains unaffected during all succeeding generations. It only throws off new forms, which are sharply contrasted with the parent, and which are from the very beginning as perfect and as constant, as narrowly defined, and as pure of type as might be expected of any species.

"These new species are not produced once or in single individuals, but yearly and in large numbers. The whole phenomenon conveys the idea of a close group of mutations, all belonging to one single condition of mutability. Of course this mutable state must have had a beginning, as it must sometime come to an end. It is to be considered as a 
period within the life-time of the species, and probably it is only a small part of it."

The following paragraphs and diagram quoted from Morgan ${ }^{21}$ give an admirably concise statement of the actual details of the primrose mutations observed by de Vries.

"We may now proceed to examine the evidence from which de Vries has been led to the general conclusions given

\section{Morgan's} account of de Vries's experi. ments.

in the preceding pages. De Vries found at Hilversum, near Amsterdam, a locality where a number of plants of the evening primrose, Enothera lamarckiana, grow in large numbers. This plant is an American form [native to the Southern United States] that has been imported into Europe. It often escapes from cultivation, as is the case at Hilversum, where for ten years it has been growing wild. Its rapid increase in numbers in the course of a few years may be one of the causes that have led to the appearance of a mutation period. The escaped plants showed fluctuating variations in nearly all of their organs. They also had produced a number of abnormal forms. Some of the plants came to maturity in one year, others in two, or in rare cases in three, years.

"A year after the first finding of these plants de Vries observed two well-characterised forms, which he at once recognised as new elementary species. One of these was $O$. brevistylis, which occurred only as female plants. The other new species was a smooth-leafed form with a more beautiful foliage than O. lamarckiana. This is O. lavifolia. It was found that both of these new forms bred true from self-fertilised seeds. At first only a few specimens were found, each form in a particular part of the field, which looks as though each might have come from the seeds of a single plant.

"These two new forms, as well as the common $O$. lamarckiana, were collected, and from these plants there have 
arisen the three groups or families of elementary species that de Vries has studied. In his garden other new forms also arose from those that had been brought under cultivation. The largest group and the most important one is that from the original $O$. lamarckiana form. The accompanying table

\section{ENOTHERA LAMARCKIANA.}

Elementary Species.

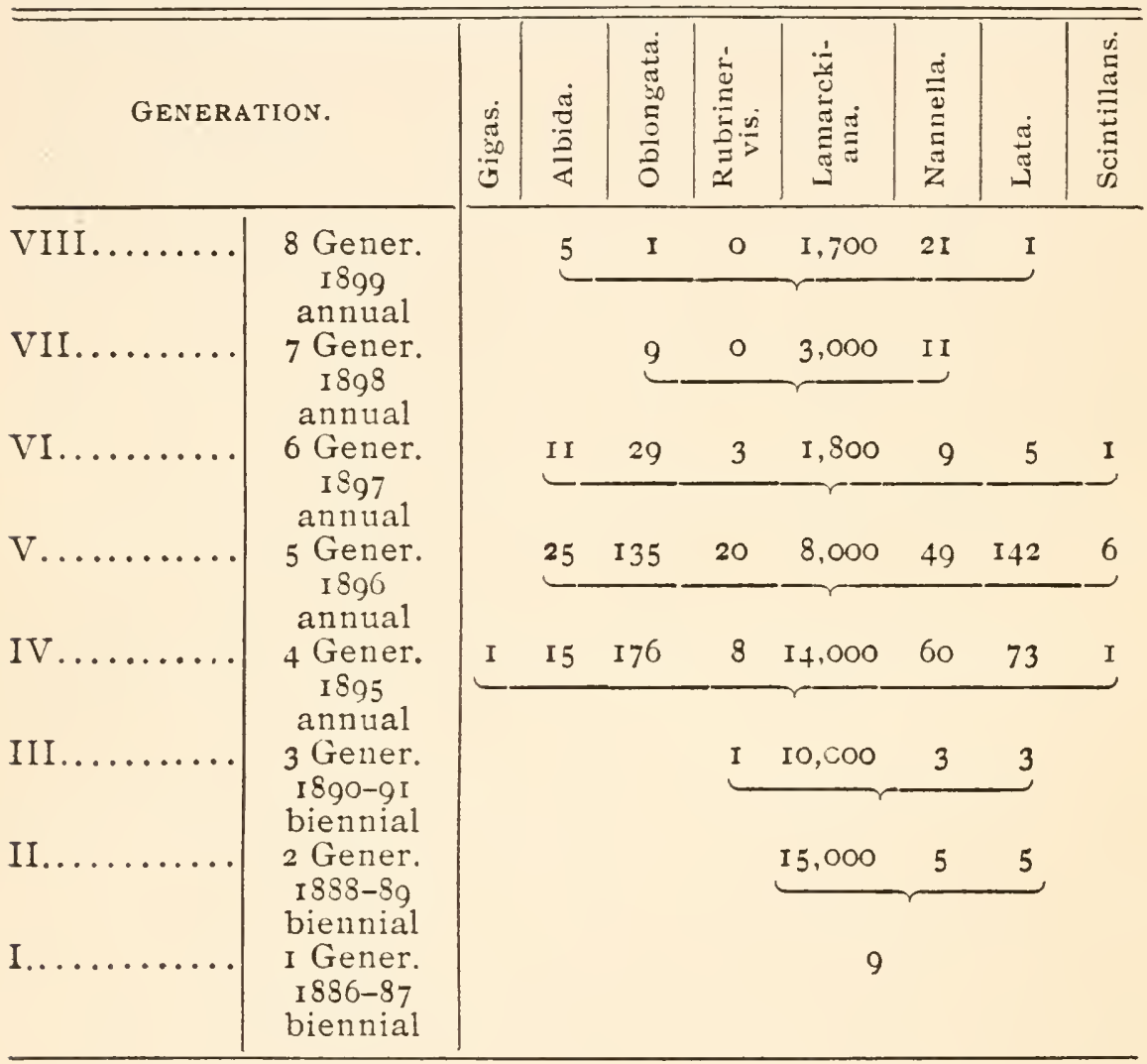

shows the mutations that arose between I887 and I 899 from these plants. The seeds were selected in each case from self-fertilised plants of the lamarckiana form, so that the new plants appearing in each horizontal line are the descendants in each generation of lamarckiana parents. It will be observed that the species, O. oblongata, appeared again and again in considerable numbers, and the same is 
true for several of the other forms also. Only the two species, $O$. gigas and $O$. scintillans, appeared very rarely.

"Thus de Vries had, in his seven generations, about fifty thousand plants, and about eight hundred of these were mutations. When the flowers of the new forms were artificially fertilised with pollen from the flowers on the same plant, or of the same kind of plant, they gave rise to forms like themselves, thus showing that they are true elementary species.* It is also a point of some interest to observe that all these forms differed from each other in a large number of particulars.

"Only one form, O. scintillans, that appeared eight times, is not constant as are the other species. When selffertilised its seeds produce always three other forms, $O$. scintillans, $O$. oblongata, and O. lamarckiana. It differs in this respect from all the other elementary species, which mutate not more than once in ten thousand individuals.

"From the seeds of one of the new forms, O. levifolia, collected in the field, plants were reared, some of which were O. lamarckiana and others O. lazifolia. They were allowed to grow together, and their descendants gave rise to the same forms found in the lamarckiana family, described above, namely, O. lata, elliptica, nannella, rubrinervis, and also two new species, O. spatulata and leptocarpa.

"In the lata family only female flowers are produced, and, therefore, in order to obtain seeds they were fertilised with pollen from other species. Here also appeared some of the new species already mentioned, namely, albida, nannella, lata, oblongata, rubrinervis, and also two new species, elliptica and subovata.

"De Vries also watched the field from which the original forms were obtained, and found there many of the new species that appeared under cultivation. These were found,

* O. lata is always female, and cannot, therefore, be self-fertilised. When crossed with $O$. lamarckiana there is produced fifteen to twenty per cent. of pure lata individuals. 
however, only as weak young plants that rarely flowered: Five of the new forms were seen either in the Hilversum field, or else raised from seeds that had been collected there. These facts show that the new species are not due to cultivation, and that they arise year after year from the seeds of the parent form, O. lamarckiana."

Since the publication of de Vries's theory and the data and considerations on which it is based (these considera-

Attitude of naturalists toward the mutations theory, tions including an unusually keen and effective criticism of the Darwinian factors of speciesforming) a great deal of discussion of the theory has been indulged in. On the whole the theory has been warmly welcomed as the most promising way yet presented ${ }^{22}$ out of the difficulties into which biologists had fallen in their attempts to explain satisfactorily the phenomena of the origin of species through Darwinian selection. And especially has been welcomed the fruitful idea of unit species characters, and of the indivisibility and the distinctness of such characters in inheritance. But with all the interest aroused by de Vries's presentation of his theory, and with all the eager scrutiny of species and records of species-appearing an output of new evidence amazingly small (when one stops to consicler the publicity gained for the theory itself and its obvious need of more confirmatory data of observation and experiment) has resulted. Even though the answer may be that experiment takes time, the lack of new observational evidence of the occurrence of mutations, ${ }^{23}$ and of the origin of new species through mutations in nature, is significant. It is my belief that a reaction against the curiously swift and widespread partial to complete acceptance of the mutation theory as the sufficient "way out" of our troubles to explain the origin of new species will soon occur. (See notes 24, 25, and 26, the appendix of this chapter, for references to certain recent criticisms of the mutation theory.) 
In closing this confessedly inadequate consideration of the important work and theorising of de Vries we should not fail to note that the mutations theory is Matations theory contrasted with Lamarckism. in strong contrast to any theory of speciesforming based on Lamarckian principles in that the newly appearing differences in organisms leading to the establishment of new species are purely congenital: that is, the mutations arise in one or both of the sex cells and only later appear in the adult organism. There is no question of the transference to the germ-cells of clianges induced in the soma by use or disuse or functional stimulus in such a way as to result in the photographic reappearance of these changes in the offspring. Mutations are true congenital or blastogenic variations. "The mutation theory," well says Conklin, ${ }^{27}$ "is a theory of the evolntion of organisms through the evolution of their germ-cells."

The mutations theory is also in sharp contrast to the theory of species-forming by geographical isolation (see chapter ix). According to de Vries many dis-

\section{Matations} theory contrasted tinct species (de Vriesian elementary species) with the isola- can and do exist side by side in the same range.
tion factor.

In fact they "are found to be heaped up in the centre of their area of distribution, but are more scattered at the periphery." 28 Now according to Wagner, Gulick, and Jordan two closely allied species, $i$. e., stock and offshoot, are found practically never to inhabit the same range, except in those cases where a migration of one type into the territory of the other has taken place after the differentiation has been effected (by previous segregation).

It would carry us into too extended a discussion to attempt to sum up here the pertinent criticism that has been directed against the mutations theory. As already indicated, there is plenty of it and of distinctly non-negligible character. But just now it seems to me sufficient simply to call attention to the extreme meagreness in quantity of the real 
scientific evidence for the theory as a theory capable of explaining spccies-forming as a wholc. There is probably no gainsaying the actuality of the occurrence of certain mutations (in de Vries's sense) nor of their establishment of certain apparently fixed new organic types (de Vries's elementary species of (Enothera). But this is very far from accepting the mutations theory as a sufficient causal explanation of the origin of the hundreds of thousands of species of animals and plants that are now or were formerly existent.

As for the help that the establishment of the mutations theory would give those biologists who reject the natural Morgan's sum. selection theory of species-forming, Morgan ${ }^{28}$ mation of the writes as follows, summing up the advantages advantages of the mutations theory. of the theory:

from the beginning, there is no difficulty in accounting for the incipient stages in the development of an organ, and since the organ may persist, even when it has no value to the race, it may become further developed by later mutations and may come to have finally an important relation to the life of the individual.

"2. The new mutations may appear in large numbers, and" of the different kinds those will persist that can get a foothold. On account of the large number of times that the same mutations appear, the danger of becoming swamped through crossing with the original form will be lessened in proportion to the number of new individuals that arise.

"3. If the time of reaching maturity in the new form is different from that in the parent forms, then the new species will be kept from crossing with the parent form, and since this new character will be present from the beginning, the new form will have much better chances of surviving than if a difference in time of reaching maturity had to be gradually acquired. 
"4. The new species that appear may be in some cases already adapted to live in a different environment from that occupied by the parent form; and if so, it will be isolated from the beginning, which will be an advantage in avoiding the bad effects of intercrossing.

"5. It is well known that the differences between related species consist largely in differences of unimportant organs, and this is in harmony with the mutation theory, but one of the real difficulties of the selection theory.

"6. Useless or even slightly, injurious characters may appear as mutations, and if they do not seriously affect the perpetuation of the race, they may persist."

Finally, the attention of students especially may be called to Bateson's interesting suggestion that mutations may be Bateson'ssog. simply pure Mendelian recessives appearing gestion thatmu- after a crossing. It would take us too far tations are

Mendelian recessives. afield to attempt to explain here to readers unacquainted with the Mendelian principles of inheritance just how Bateson's suggestion has a certain plausibility. It must suffice to say that Mendel, and after him a considerable number of present-day students of heredity, have shown that after a crossing between two individuals sharply contrasting in regard to some particuliar character, as colour of hair, all the offspring of the first generation may agree in showing but one of the two parental colours (the dominant), but that if these first generation offspring are bred to each other, or to similarly produced individuals, the members of the second generation will split up as regards the character in question, some showing one of the grand-parental hair colours, and the rest showing the other one. Now breeding likes together, it would be shown in third generation groups that one of these colours, and, namely, that one called the recessive, which did not appear at all in the first generation, will always henceforth breed true while the other colour may or may not breed true (de- 
pending on whether in making the matings pure dominants or cross-bred dominants happen to be used). Thus the sudden appearance in the second generation of the latent or recessive characteristic, and its breeding true, are occurrences which might readily be interpreted as the appearance of a mutation or true-breeding sport by an observer unacquainted with the ancestry of the individuals under his eye. Altcrnative Theories to Explain Secondary Sexual Characters.-Before closing this discussion of theories which have been proposed as substitutes for the Darwinian selection theories to explain the actual conditions in the organic world as we see it to-day, and as we know it to have been in past ages, we should mention, at least, the few attempts to formulate a substitute explanation for the existence of secondary sexual characters. The discrediting of the sexual selection theory as such an explanation is certainly nearly complete. But it is interesting to note how lame and unconvincing are the proposed substitute explanations.

The first, and most appealing one, is the explanation that the extra plumes, wattles, horns, the unusual display of bright colours, etc., of the males are simply the

Extra growths manifestations of an extra growth-force or the result of extra vigour. vigour exhibited by the male in the breeding season. The female also may be endowed with extra growth-vigour at this time, but it goes, in her case, to the formation of ova, to the storing up of food in or around the egg cells. The songs, the dances, the violent play and antics of the males common to many species of birds, insects, spiders, etc., are also attributed to this special or sexual vigour.

Now while such secondary sexual characters as colour, plumes, wattles, etc., might perhaps well enough seem to be the outcome of an extra growth-vigour, what about such special male characters as the stridulating organs of male katydids and crickets, and other similar complex, highly 
perfected, adaptive structures? A male cricket has the veins at the base of one wing-cover curiously and complexly modified in course and in superficial structure, while the veins of the other wing-cover are also modified in a way differing from but exactly correlated with the venation of the first wing, the whole specialisation resulting in a combination of file, scraper, and vibrating membrane to form the effective musical instrument of the insect. Can such an adaptive structural modification be conceived to be a sudden bursting forth or result of superabundant growth-force? And many of the secondary sexual characters are of this class of complex adaptive specialisations. The growthforce explanation can, at best, explain but few of the various categories of sexual dimorphism. Some explanation more directive in its character is needed for these others.

Even more restricted in its application, and less convincing in the assumptions at its very base, is the curious replacement theory of Emery. ${ }^{30}$ This investiEmery's theory gator believes that sexual selection can explain
of the origin of secondary sexual but few if any cases of sexual dimorphism, and characters. would explain these other cases largely by the sudden appearance (mutation or sport) of a second form of male or female, the persistence for a while of the two forms side by side, as now exemplified by numerous dimorphic or polymorphic (or di- or polychromatic) species, and then the gradual or sudden dying out (killing out by selection?) of the older original form (the one resembling the other sex), thus leaving the once dimorphic sex represented only by the newer aberrant form. While such an explanation may possibly explain a few cases of extreme sexual dimorphism or dichromatism, it certainly will not do for the many cases of secondary sexual difference constituted by the existence in one sex of some one or few particular adaptive specialisations for music-making, scent-producing, or weapon-forming, not possessed by the other sex. 
Cunningham $^{31}$ (and also at about the same time Wiglesworth) in 1898 suggested, on a neo-Lamarckian basis, that

Conningham's explanation of secondary serual characters.

secondary sexual characters were due to the stimulation of parts through use or external violence or irritation. Cunningham would explain all adaptations as derived from variations actually induced by responses or reactions to the environment. His theory of the origin of secondary sexual characters would simply be the explanation of the adaptive differences between two individuals of a species on the same basis as the explanation of the adaptive differences between individuals of different species. His argument is summed up as follows: "Selection assumes the occurrence of variations; the variations must either be similarly indefinite and promiscuous in all cases, or they must be different in different cases-that is, in different species, different sexes, different stages of life. If they are different in different cases, then selection is a very unimportant matter, for the chief questions are evidently what are the differences and what made them differ. To deny that the variations have always been different in different cases is to deny the most evident facts; such denial might be possible when we consider only the difference between species, but it is impossible when we study the differences between the sexes in the same species and between different stages in the same individual. In all cases the variations correspond to differences in habits and mode of life, and in many cases are of the same kind as the changes known to be produced in the individual by special stimulation or special activity of organs; this is true of many and probably of all cases of adaptation. The general conclusion is that adaptation is not produced indirectly by the selection from indefinite variations, but directly by the influence of stimulation in modifying the growth of the parts or organs of the body."

Wallace $^{32}$ has suggested that the differences in color- 
ation between males and females are due largely to the necessity of the better protection of the young Wallace's suggestion. producing and (in the case of birds and mammals) young protecting and caring for female, and hence the acquirement on her part of a dull inconspicuous protective colour-pattern. Wallace's large acquaintanceship with birds and butterflies enables him to illustrate his theory by many apparently confirmatory examples, but as soon as one stops to consider the matter thoughtfully the impossibility of the general or even wide application of this explanation of secondary sexual characters is at once apparent. It is necessarily limited to one single category of sexual differences.

Barrett-Hamilton ${ }^{33}$ has noted that both sexes of the salmon (Onchorhynchus) become markedly discoloured during the spawning season. The discoloration is accompanied by overgrowth or hypertrophy, especially of the jaws. "I cannot believe," he says, "that this is of an æsthetic nature, since these phenomena terminate in the death of the fish. They seem to be, in fact, merely the outward symptoms of what, as I have persuaded myself from personal observation in Kamschatka, is a pathological condition accompanying, and perhaps resulting from, the growth of the ova and milt. I regard the whole metamorphosis as a purely excretory phenomenon resulting from the upsetting of the metabolism due to the concentration of the whole vital force on the effort to produce the greatest possible amount of spawn.

"May not such a state of things be invoked to explain the nuptial changes of our own salmon so strangely assumed before and lost after the breeding-season? Is it not possible that in the phenomena displayed by the spawning Onchorhynchus we may have a clue to the origin of the hitherto inexplicable temporary and permanent sexual characters of the vertebrates and even of some invertebrates, of which 
it may be that the origin has been primarily excretory and only secondarily protective or æsthetic?"

The plain truth is that the satisfactory, all-explaining explanation of secondary sexual characters and sexual dimorphism as a whole is yet to be formulated.

\section{APPENDIX.}

${ }^{1}$ At some time between I855 and 1865, Gregor Johann Mendel, an Augustinian monk in the small Austrian village of Brünn, car-

Mendel and ried on pedigree cultures of peas and some other his work. plants in the gardens of his cloister. From this work he derived data that he read, together with his interpretation of their significance, before meetings of the Natural History Society of Brünn, and which, in the same year of their reading, I865, were published under the title "Experiments in Plant-hybridisation," in the Ablandlungen (Vol. IV.) of the society. Mendel was the son of a peasant and had been educated in Augustinian foundations and ordained priest. For two or three years he studied physics and natural science in Vienna, and refers to himself as a student of Kollar. He became Abbot of his cloister, and was for a time president of the Brünn Natural History Society. Such are the essential details of the education and situation of the man whose name will undoubtedly live forever in the annals of biological science. For the observations, experiments, and conclusions of Mendel on inheritance have taken their place already as matters of fundamental importance in the study of heredity. It would take us too far afield even to outline Mendel's work and derived "principles of heredity." but the interested reader can find an admirable exposition and discussion of them (together with translations of Mendel's own papers) in Bateson's "Mendel's Principles of Heredity," I902.

For an excellent exposition of Mendel's work and other similar work by botanists, see Lotsy. J. P., "Vorlesungen über Descendenztheorien," Vol. I, chap. viii, Igo6.

Cuenot, in L'Année Biologique, Vol. VII, for 1902, pp. 58-77, gives an excellent review of the work of Mendel, de Vries, Correns. and Tschermak; and a bibliography, relating to the so-called Mendelian laws of the principles of heredity.

Bateson, in "Progressus rei Botannicae," Vol. I, pp. 368-468, I907, gives a complete abstract of the nature of the work and its results which has been done on the Mendelian problem from the time of 
Mendel to the present. The bibliography in connection with this paper is practically complete up to the date of its making.

${ }^{2}$ Correns, C. G., "Über Levkoyen-Bastarde, zur Kenntniss der Grenzen der Mendel'schen Regeln," Botan. Centralbl., LXXXIV, References to p. 97, I900; "Über Bastarde zwischen Rassen von rocent work on Zea Mays," Ber. Deut. Bot. Ges., XIX, 2I I (IgoI); Mendelism, "Bastarde zwischen Maisrassen, Bibliotheca Botanica," Heft 53, I90 ; "Über Bastardirungs-Versuche mit MirabilisSippen," Ber. Deut. Bot. Ges., XX, 594-608, I903.

${ }^{3}$ T. E. Tschermak, "Über künstliche Kreuzung bei Pisun sativum," Zeitschr. f. d. Landwirthsch. Versuchswesen, III, 465-555, I900; "Weitere Beiträge über Verschiedenswerthigkeit der Merkmale bei Kreuzung von Erbsen und Bohnen," ibid. IV, 64I ff., I90I; "Über Züchtung neuer Getreiderassen mittelst künstlicher Kreuzung," ibid. IV, 1902. "Die Theorie der Kryptomerie und des Kryptohybridismus," Beihefte z. Bot. Centralbl., XVI, 25 pp., I903; "Weitere Kreuzungsstudien an Erbsen," Zeitschrift f. d. LandwirthVersuchswesen in Oesterr., 106 pp., I904.

"See Darwin, "Animals and Plants Under Domestication," Vol. I, chap. iii, p. I04. "In some few instances new breeds [of sheep]

Darwin on have suddenly originated; thus in I79I a ram-lamb was race origin from born in Massachusetts, having short crooked legs and sports.

a long back, like a turnspit dog. From this one lamb the otter, or ancon, a semi-monstrous breed, was raised; as these sheep could not leap over the fences it was thought that they would be valuable; but they have been supplanted by merinos, and thus exterminated. The sheep are remarkable from transmitting their character so truly that Colonel Humphreys never heard of "but one questionable case' of an ancon ram and ewe not producing ancon offspring. When they are crossed with other breeds the offspring, with rare exceptions, instead of being intermediate in character, perfectly resemble either parent; even one of twins has resembled one parent and the second the other. Lastly, the ancons have been observed to keep together, separating themselves from the rest of the flock when put into enclosures with other sheep.'

"A more interesting case has been recorded in the Report of the Juries for the Great Exhibition (I85I), namely, the production of a merino ram-lamb on the Mauchamp farm. in I828, which was remarkable for its long, smooth, straight, and silky wool. By the year I833 M. Graux had raised rams enotigh to serve his whole flock, and after a few more years he was able to sell stock of his new breed. So peculiar and valuable is the wool, that it sells at 25 per cent. above the best merino wool: even the fleeces of halfbred animals are valuable, and are known in France as the 
'Mauchamp-merino.' It is interesting, as showing how generally any marked deviation of structure is accompanied by other deviations, that the first ram and his immediate offspring were of small size, with large heads, long necks, narrow chests, and long flanks, but these blemishes were removed by judicious crosses and selection. The long smooth wool was also correlated with smooth horns; and as horns and hair are homologous structures, we can understand the meaning of this correlation. If the Mauchamp and ancon breeds had originated a century or two ago, we should have no record of their birth; and many a naturalist would no doubt have insisted, especially in the case of the Mauchamp race, that they had each descended from, or been crossed with, some unknown aboriginal form."

The Paraguay cattle are a hornless race which is composed of the descendants of a hornless bull which was born in Paraguay in I770.

A recent interesting case wholly parallel with those just recorded, is that of the Polled Herefords originating in I889 in Kansas, U. S. A. (see Guthrie, W. W., "History of Polled Herefords," in Proc. Am. Brecders' Assoc., Vol. II, pp. 93-95, I906).

"In the fall of I889, W. W. Guthrie. Sr., of Atchison, Kansas, now deceased, discovered among the calves that had been weaned

A recentex- at his ranch in Chase County, Kansas, one with Hereample of race ford markings which was perfectly polled. In his origin from a herd were purebred Shorthorn as well as purebred sport in cattle. Hereford cows. Two purebred Hereford bulls were at the head of the herd. This calf was the product of a threequarter Hereford and one-quarter Shorthorn cow by one of the two purebred Hereford bulls, Grateful 3d, No. 8,oor, and Treasurer, No. 10,585. Discovery, as the calf was subsequently named, was a well-formed animal, with a good loin, and well-developed hindquarters, and had the Hereford colour and markings, with body more on the type of the Shorthorn. At three years of age he weighed, without special feeding, I.986 lbs.

"It then occurred to Mr. Guthrie that by using this animal he might in time establish a herd of polled Herefords, and that the experiment was at least worth trying. Shortly afterwards, he happened to meet on the train Chancellor Snow, of the Kansas State University, on his way to lecture before the Atchison High School on evolution, and during their several hours conversation discussed with him the proposition of animal architecture. The Chancellor agreed that the proposition of establishing a polled Hereford herd was one worth considering, and Mr. Guthrie determined to carry out his ideas along this line. 
"When Discovery matured it was found that his calves from horned cows were all hornless. In I893, a two-year-old bull and six heifers were selected and brought to Atchison County, where the experiment was carried on under the personal supervision of Mr. Guthrie and with very encouraging results.

"On October 3I, I898, Mr. Guthrie purchased at the Kansas City Scott \& Whitmann sale four purebred Hereford heifers. The calves from these horned heifers by a descendant of Discovery were found to be in every instance polled, only two showing scurs, scarcely noticeable, and loose in the skin. A number of purebred Hereford heifers were later obtained from the Funkhouser herd, and still later others from the Armour herd, and equally good results were obtained.

"Eight head of polled Herefords were exhibited by Mr. Guthrie at the Omaha Exposition, and, while these animals did not present the finished appearance of modern show cattle, not having been forced from date of birth, they attracted such attention that articles on the herd were published in the newspapers and periodicals throughout this country, and even in such far-away lands as Australia and New Zealand.

"The desirability of Herefords without horns, the one objection which Hereford breeders had been willing to admit, becoming apparent. other Hereford breeders began to take notice of an occasional polled calf, freaks of nature as they were considered, appearing in their herds, and soon a brisk demand for polled bulls developed. animals being shipped as far north as South Dakota, and Wisconsin, and as far south as Texas. Breeders in many instances have reported that in their horned herds, after several years' breeding. not a single calf had come with horns, and only occasionally would slight scurs, loose in the skin. appear." ...

"In December, 1904, four head of polled Herefords from West Virginia were exhibited at the International Live Stock Show at Chicago in connection with horned Herefords, and during the past season a larger number from the same State were exhibited throughout the eastern circuit of fairs. At the American Royal Cattle Show at Kansas City, last October, seven head from the original herd were exhibited. As a result of these exhibits, many horned Hereford breeders are now turning their attention to the subject of breeding Herefords without horns, and so great has become the demand for animals with which to start polled herds that at the last meet of the National Polled Hereford Breeders' Association it was found that the members were unable to supply enough young bulls to meet the demand.

"Quite a number of purebred Hereford calves, termed 'freaks' 
or 'sports,' have been dropped in this country, and some have been kept. The President of the National Polled Hereford Breeders' Association has a perfectly polled cow, the produce of one of his. purebred horned Hereford cows by a purebred horned Hereford bull, and has lately purchased a purebred polled Hereford bull. The original herd now contains two polled males and a number of polled females, descended direct from purebred Herefords. The above animals are registered in the American Hereford Record.

"During a trip through England several years ago, Mr. Guthrie made inquiry among Hereford breeders and found that, while an occasional polled animal had been calved, they were considered as freaks of nature by the owners and butchered."

${ }^{5}$ Bateson, Wm., "Materials for the Study of Variation," I894.

${ }^{6}$ Kölliker, A. von, "Über die Darwin'sche Schöpfungstheorie," Zeitsch. f. wiss. Zool., Vol. XIV, pp. 174-186, 1864.

${ }^{7}$ Dall, W. H., I877.

${ }^{8}$ Galton. Francis, "Natural Inheritance," p. 32, 1889.

${ }^{\circ}$ Galton, Francis, loc. cit. p. 27, "The distinction between primary Galton's dis- and subordinate positions of stability will be made cussion of specific stability. clearer by the help of Fig. I, which is drawn from a model I made. The model has more sides, but Fig. I suffices for illustration. It is a polygonal slab that can be made to stand on any one of its edges when set upon a level table, and is
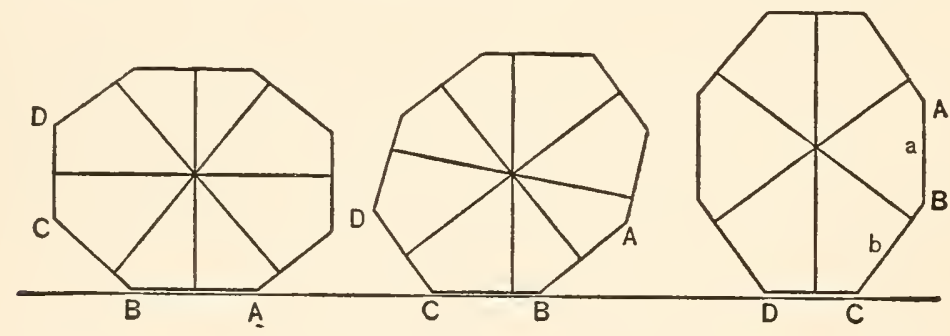

FIG. I

intended to illustrate the meaning of primary and subordinate stability in organic structures, although the conditions of these must be far more complex than anything we have wits to imagine. The model and the organic structure have the cardinal fact in common, that if either is disturbed without transgressing the range of its stability, it will tend to reëstablish itself, but if the range is overpassed it will topple over into a new position; also that both of them are more likely to topple over towards the position of primary stability, than away from it.

"The ultimate point to be illustrated is this. Though a long established race habitually breeds true to its kind, subject to small 
unstable deviations, yet every now and then the offspring of these deviations do not tend to revert, but possess some small stability of their own. They, therefore, have the character of sub-types, always, however, with a reserved tendency, under strained conditions, to revert to the earlier type. The model further illustrates. the fact that sometimes a sport may occur of such marked peculiarity and stability as to rank as a new type, capable of becoming the origin of a new race with very little assistance on the part of natural selection. Also, that a new type may be reached without any large single stride, but through a fortunate and rapid succession of many small ones.

"The model is a polygonal slab, the polygon being one that might have been described within an oval, and it is so shaped as to stand on any one of its edges. When the slab rests, as in Fig $\mathrm{I}$, on the edge $\mathrm{A} \mathrm{B}$, corresponding to the shorter diameter of the oval, it stands in its most stable position, and in one from which it is. equally difficult to dislodge it by a tilt either forwards or backwards. So long as it is merely tilted it will fall back on being left alone. and its position when merely tilted corresponds to a simple deviation. But when it is pushed with sufficient force, it will tumble on to the next edge, $\mathrm{B} C$, into a new position of stability. It will rest there, but less securely than in its first position; moreover, its range of stability will no longer be disposed symmetrically. A comparatively slight push from the front will suffice to make it tumble back, a comparatively heavy push from behind is needed to make it tumble forward. If it be tumbled over into a third position (not shown in the figure), the process just described may recur with exaggerated effect, and similarly for many subsequent ones. If, however, the slab is at length brought to rest on the edge C D, most nearly corresponding to its longest diameter. the next onward push, which may be very slight, will suffice to topple it over into an entirely new system of stability; in other words, a 'sport' comes suddenly into existence. Or the figure might have been drawn with its longest diameter passing into a projecting spur, so that a push. of extreme strength would be required to topple it entirely over.

"If the first position, A B, is taken to represent a type, the other portions will represent sub-types. All the stable positions on the same side of the longer diameter are subordinate to the first position. On whichever of them the polygon may stand, its principal tendency on being seriously disturbed will be to fall back towards the first position; yet each position is stable within certain limits.

"Consequently, the model illustrates how the following cond:tions may co-exist: (I) variability within narrow limits without prejudice to the purity of the breed; (2) partly stable sub-types; 
(3) tendency, when much disturbed, to revert from a sub-type to an earlier form; (4) occasional sports which may give rise to new types."

${ }^{10}$ Emery, C., "Gedanken zur Descendenz- und Vererbungstheorie," Biolog. Centralbl., Vol. XIII, pp. 397-420, I893.

${ }^{11}$ Korschinsky, S., "Heterogenesis und Evolution," Naturw. IVochenscrift, Vol. XIV, pp. 273-278, I899; also "Heterogenesis u. Evolution," Flora, oder Allg. Bot. Zeit., Ergänzungsbd. 89, pp. 240368, I90I.

${ }^{12}$ De Vries, H., "Die Mutationstheorie," Vol. I, I90I, Vol. II, 1903.

\section{References to} discussions by de Vries of species-forming.
${ }^{13}$ De Vries, H., "Species and Varieties, Their Origin by Mutation" (ed. by MacDougal), 1905.

${ }^{1 \pm D e}$ Vries, H., "Die Mutationstheorie," Vol. I, p. 150,1901 .

${ }^{13}$ De Vries, H., "Die Mutationstheorie, Vol. I. p. 362, I90I.

${ }^{16}$ De Vries, H., "Species and Varieties," p. 6.

${ }^{17}$ De Vries, H., "Species and Varieties," pp. 8-9.

${ }^{18}$ De Vries, H., "Species and Varieties," p. Io.

${ }^{19}$ De Vries, H., "Species and Varieties," p. I3.

${ }^{20}$ For an excellent exposition and discussion of the de Vries mutation theory and mutations, see Lotsy, J. P., "Vorlesungen über Descendenztheorien," Vol. I, chaps. xiv and xv, I906.

${ }^{21}$ Morgan, T. H., "Evolution and Adaptation," pp. 294-295, 1903.

22 As evidence of the interest and favour with which American biologists have received the theory, the six addresses on "the muta-

\section{American} opinion of the matations theory. tion theory of organic evolution" delivered before the American Society of Naturalists at Philadelphia, December 28, 1904. may be especially referred to. These addresses by naturalists distinguished for their work in different phases of biology, as systematic and œcologic botany, cytology, human anatomy, animal œcology, etc., are printed in Science, N. S., Vol. XXI, pp. 52I-543 (April 7, 1905), and from them I quote various paragraphs indicating some of the points of view of the speakers and some of the arguments advanced in favour of the theory.

"On the whole, it appears that the formation of new breeds begins with the discovery of an exceptional individual, or with the production of such an individual by means of cross-breeding. Such exceptional individuals are mutations" (Castle, p. 524).

"Modification of character by selection, when sharply alternative conditions ( $i$. e., mutations) are not present in the stock, is an exceeding difficult and slow process, and its results of questionable permanency. Even in so-called 'improved' breeds, which are sup- 
posed to have been produced by this process, it is more probable that the result obtained represents the summation of a series of mutations rather than of a series of ordinary fuctuating variations. For mutations are permanent: variations transitory" (Castle, p. 524).

"It is to my mind impossible to find any support for a theory of evolution by minute changes from the study of anatomical variations. I should not venture to say, on the other hand, that they give any direct support to the theory of mutation: but, at least, they are not in disaccord with it" (Dwight, p. 532).

"It seemed necessary to discuss ethological characters at some length for the purpose of vindicating their importance. Having attempted this, I may say that these characters seem to me to offer even fewer difficulties than the morphological characters to the acceptance of the mutation theory, for the reason that the ethological and psychological processes are conceived primarily as qualities and not quantities. Thus the psychical elements, $i$. e.. the simple feelings, cravings. and sensations, are disparate qualitative processes which cannot be derived from one another or from some more undifferentiated process. This is still more evident in the case of the complex psychical phenomena. Similarly, instincts, with which ethology is most concerned, when resolved into their simplest components are seen to consist of discrete reactions which cannot be shown to arise from one another. Although, on the other hand, the measurable intensities and durations of the reactions are analogous to the fluctuating structural variations. it is even more difficult for the psychologist to conceive of a particular feeling, craving, or sensation as arising from the greater or less intensity or duration of some other psychic process, than it is for the morphologist to conceive of the origin of new characters from the fluctuating variations of structure" (Wheeler, p. 539).

"Mutation is even more urgently demanded for the explanation of many other instincts, especially those of symbiotic and parasitic species and of species with profound and sudden metamorphosis. In these cases, a particular activity, on which most often depends the life of the individual or of its progeny, has to be performed with a high degree of proficiency at its very phylogenetic inception or it can be of no advantage to the individual or the race. Such cases, with which you are all familiar, have ever been the insurmountable obstacle to the evolution of instincts on the theory of fluctuating variations and natural selection. The theory of organic selection seems to me merely to conceal but not to overcome the difficulties. The mutation theory frankly avoids the difficulties even if it fails to throw any light on the origin of the muta- 
tions and bundles this into the germ-plasma. It is, of course, no objection to the theory that it leaves something under the heavens to be accounted for. This is rather to be regarded as one of its chief virtues. As working naturalists we have reason to be most suspicious of the theories that explain everything" (Wheeler, pp. 539540 ).

"In view of the amount of orderly and well-authenticated evidence now at hand, it may be regarded as demonstrated that characters, of appreciable physiological value, originate, appear in new combinations or become latent, in hereditary series of organisms, in such a manner as to constitute distinct breaks in descent" (MacDougal, p. 540).

${ }^{23}$ Some of de Vries's experiments and observations on the Lamarck primrose have been repeated (with naturally some variation) in the New York Botanic Garden, by MacDougal and assistants. See MacDougal, D. T., "Mutation in Plants," Amer. Nat., Vol. XXXVII, pp. 737-770, I903; also, "Mutants and Hybrids of the Enotheras," by D. T. MacDougal, assisted by A. M. Vail, G. H. Shull, and J. K. Small, Pub. No. 24, Carnegie Inst. of Wash., 1905.

I am aware of the rather sweeping statements made by some biologists touching the probability of the origin by mutation of many species, or at least, races of animals and plants. For example, Castle (Scicnce, N. S., Vol. XXI, p. 522, 1905) says: "So far, however, as these various sorts of evidence go, they indicate that the material used by breeders for the formation of new breeds consists almost exclusively of mutations." And Davenport (Scicnce, N. S., Vol. XXII, p. 372, 1905) 'says: "Undoubtedly many, if not most, of the characteristics of the races of domesticated animals and probably feral species have arisen by mutation." He then refers, as example, to the qualities that differentiate the races of poultryfeathered feet, rose comb, elongated tail, taillessness, silky feathers, frizzled feathers, cerebral hernia, polydactyl feet, albinism, and many others. But I have been assured by Luther Burbank, the most experienced and distinguished plant breeder in this country, that the many races of plants actually produced by him have not been derived from mutations. But on the contrary, that the selection of small variations-a special abundance and variety of these variations usually being induced by hybridisation and by change of environment-has been his almost exclusively relied-on means for producing new forms of plants. As a matter of fact the cases actually adduced by upholders of the de Vriesian theory as supports for it are astonishingly few. Castle (Science, N. S., Vol. XXI, pp. $522-523,1905)$ calls attention to the sudden appearance of a supcr- 
numerary fourth digit on one of the hind feet of one of nine young produced by a certain pair of guinea-pigs. "Neither of the parents had such a digit, nor had I ever heard of the existence of such a character before, either in any of the wild Caviedæ or among domesticated cavies or guinea-pigs. Further, I have been able to find no reference to such a thing in the literature of the group, though I have several times since found this same mutation in other herds of guinea-pigs. The mother of my four-toed pig never produced another similar individual, though she was the mother in all of thirty young. The father, however, who sired in all I39 young, had five other young with extra toes, but these were all by females descended from himself, so that it seems certain that the mutation had its origin in this particular male. By breeding together the fourtoed young and selecting only the best of their offspring, I was able within three generations to establish a race with a well-developed fourth toe on either hind foot. This race was not created by selection, though it was improved by that means." Castle also had another mutation appear in a second family of guinea-pigs. "A few individuals were found to have hair about twice as long as that of their parents and grandparents. Intermediate conditions did not occur. Long-haired individuals mated together were found to produce only long-haired young, so that a new breed was already fully established without the exercise of any selection." Casey (Science, N. S., Vol. XXII, p. 308, I905) presents a number of facts touching the sudden appearance of certain molluscous genera in early Eocene strata, and in certain Lower Oligocene rocks, which seem to be evidence for the mutations theory. "At least, the mutation theory is evidently the best that has been advanced to account for these known facts." Scott (Science, N. S., Vol. XXII. pp. 27r-282) attempts to make out a case for the mutational origin of nine kinds of North American birds that, because of their rarity and the obscure character of the records of their occurrence, are mostly rather puzzling to ornithologists. (They are all included in the "hypothetical list" of the American Ornithologists' Union Check-List.) But this attempt is robbed of much significance by Allen's critical discussion of it (Science, N. S., Vol. XXII, pp. 43I434, I905). Morgan (Harper's Montllly Mag., Vol. CVI, p. 478) refers to the "japanned" turkeys, a kind of bronze-shouldered aberration that appears occasionally in flocks of turkeys, as "mutations." These turkeys are called attention to by Darwin ("Variation of Animals and Plants ('nder Domestication," Vol. I, p. 305). Indeed, more cases of such mutations are referred to and described by Darwin himself than by all those who have attempted recently to adduce examples, for the support of the mutations theory, of an 
alleged case of sudden appearances of modified animals or plants that seem to breed true. But these infrequent prepotent sports, or discontinuous variations, do little to furnish any convincing foundation for de Vries's theory. Far better than all of them are de Vries's own long and carefully observed primrose mutations. Here, besides a few single mutations, were several that appeared in considerable numbers, which is a condition almost imperatively necessary for the successful propagation of a new organic type.

A recent record of an alleged case of mutation is Schaffner's, "A Successful Mutant of Verbena without External Isolation," in Ohio Naturalist, Vol. VII, pp. 3I-34, December, 1906.

As Davenport ("The Mutation Theory in Animal Evolution," Science, N. S., Vol. XXIV, pp. 556-558, November, I906) puts it: "The real argument for discontinuity in evolution is the occurrence of characteristics in nature that are discontinuous and which never show intergrades. The mere fact of discontinuity between species of the same genus is not sufficient to prove that they have arisen by mutation. It must be shown that the differential characters are in essence discontinuous. The practical way to get at the true nature of characteristics, whether continuous or discontinuous, is by their behaviour in inheritance. If, in cross-breeding, a character tends to blend with the dissimilar character of its consort it must be concluded that the character can be fractionised and intergrades are possible. If, on the contrary, the characteristic refuses to blend, but comes out of the cross intact, as it went in, the conclusion seems justified that the characteristic is essentially integral and must have arisen completely formed, and hence discontinuously.

"Using this criterion, I have of late been testing the application of the mutation theory to animals and have had an opportunity to. examine the experiments of others. Some of the work has been done on the characteristics of domesticated 'races,' others on wild varieties. There seems to be no difference in the behaviour of characteristics of domesticated and wild varieties. The result is. that most characteristics, but not all, fail to blend and are strictly alternative in inheritance. I interpret this to mean that the characteristic depends on a certain molecular condition that does not fractionise. The inference is that if the characteristic is incapable of gradations now it has always been so and hence must have arisen without gradations, i. e., discontinuously. Examples of such discontinuous characteristics are the spots in the elytra of certain beetles, the crest on the canary, the form of the comb in poultry, extra toes, black plumage, and colour of iris. One who sees the striking failure of these characteristics and many others to be modified in 
any important way will feel convinced that they are not capable of forming intergrades and hence could not have arisen gradually."

${ }^{24}$ C. B. Davenport ("Evolution Without Mutation," Jour. of Exper. Zool., Vol. II, pp. I37-I43, I905), in a recent short paper,

Davenport's examples of species-origin by slight continuous change, adduces facts concerning the variation and evolution of Pectens, which lead him to conclude that the races of Pecten inhabiting different geographical regions are connected so plainly by integrating variations. that there can be no question of mutations in connection with their origin. They must have arisen through evolution by trivial variation. Davenport concludes his paper with the following summary: "The process of evolution has taken place by various methods and not always in the same way. It is not more justifiable to maintain that all evolution is by mutation than that evolution has always proceeded by slow stages. The best evidence for slow evolution is found in wide-ranging species which, while differing greatly at the limits of their range, exhibit all gradations in intermediate localities (Mclospiza, Pecten); also in fossil series (Pecten eborcus and $P$. irradians) where the change from one horizon to the next is of a quantitative order. Thus evolution may take place without mutation."

Naturalists whose special field of study is systematic and faunistic rather than morphologic or experimental, seem to be slow to

Merriam's find much good in the mutations theory. Indeed, criticism of the some of them seem to be quick to find much that is mutationstheory. ill in it. For example, Merriam and Allen, deans of American faunistic students of birds and mammals, are both strong antagonists of the mutations theory. Merriam, in an address as chairman of the zoological section at the I905 meeting of the American Association for the Advancement of Science ("Is Mutation the Factor in the Evolution of the Higher Vertebrates?" Science, N. S., Vol. XXIII, pp. 24I-257, I906), shows by the use of illustrations drawn from the distribution and taxonomy of American chipmunks and ground squirrels that the mutations theory cannot by any means explain all species-forming. "My argument," says Merriam, "is not that species of plants may not in rare cases arise in perpetuation of sport characters, as de Vries believes they do, but admitting this, my contention is that the overwhelming majority of plants, and so far as known, all animals, originate in the generally recognised way by the gradual development of minute variations. The theory of origin of species by mutation, therefore, far from being a great principle in biology, as some seem to believe, appears to be one of a hundred minor factors to be considered in rare cases as a 
possible explanation of the origin of particular species of plants, but so far as known, not applicable in the case of animals."

Certain naturalists even go so far as to express some doubt about the value of the mutations observed by de Vries in the primroses. This doubt touches two points. First, the possibility that the mutating primroses are not pure cultures, but are hybrids; second, that when an investigation of the wild primroses in their native locality (southern United States) is made it may be found that these primroses in true wild condition do not mutate. Touching these two points, it should be said that de Vries has convinced himself that his cultures are pure, and has tried to discover the actual conditions existent among the primroses in their native habitat. As a matter of fact, the Lamarckian primrose seems to be practically extinct as a wild species. De Vries ("Über die Dauer der Mutationsperiode bei Enothera Lamarckiana," Ber. Deutsch. Bot. Gescll., Vol. XXIII, pp. 382-387, 1905) found specimens of Enothera Lamarckiana in three botanical collections in the United States. These specimens were collected in Florida and Kentucky. However, since these specimens were taken (the Florida ones in I860) the species has not been observed, perhaps on account of lack of close observation, perhaps because actually disappeared. Therefore the question whether the Lamarckian primrose mutates in wild condition remains undecided.

${ }^{25}$ The most considerable critical discussion and analysis of the mutations theory is that made by Plate in his review of Morgan's

Plate's criti- "Evolution and Adaptation. (Plate, L., "Darwinismus cism of the ma- kontra Mutationstheorie," Archiv f. Rassen- und Getations theory. sellschafts-Biologic, Vol. III, pp. I83-200, I906.) In the course of his critical review of Morgan's book (which book is at once an attack on Darwinism and an upholding of the mutations theory), Plate points out keenly and strongly the weak places in de Vries's theory. As a general substitute for the natural selection theory as an explanation of adaptation as well as species-forming, the mutations theory is open to many of the same objections as the Darwinian theories. Plate takes up, serially, Morgan's claims for the mutation theory and readily shows their unconvincing character. I quote some of this analysis, as follows:

"Es ist von Interesse zu sehen, welche Gründe Morgan bestimmen, der Mutationstheorie trotz ihrer fundamentalen Mängel den Vorzug zu geben vor der alten Darwin'schen Auffassung. Auf. S. 298 zählt er die 'Vorzüge' dieser Theorie auf, die aber meines Erachtens alle vor der Kritik nicht standhalten.

" 'I. Da die Mutationen von Anfang an vollständig ausgebildet auftreten, fällt die Schwierigkeit fort, die Anfangsstadien in der 
Entwicklung eines Organs zu erklären, und da das Organ sich erhalten kann, selbst wenn es keinen Wert fur die Rasse hat, kann es durch spätere Mutationen weiter entwickelt werden und schliesslich eine wichtige Beziehung zum Leben des Individuums erlangen.'

"Die erwähnte Schwierigkeit, die Anfangsstadien nützlicher Strukturen und Organe nach der Darwin'schen Auffassung zu erklären, lässt sich nicht leugnen, aber sie ist, wie ich in dem oben erwähnten * Buche gezeigt $\mathrm{zu}$ haben glaube (S. 34-5I), zu überwinden, besonders dann, wenn man in der Vererbungsirage Gegner von Weismann ist und annimmt, dass ein durch Generationen ausgeübter Reiz sich in seinem Effekt allmällich steigert (Prinzip der Orthogenese) und wenn man sich darüber klar ist-was Morgan vollständig entgangen zu sein scheint-das der Konkurrenzkampf zwischen zwei Arten sehr oft nicht sofort, sondern im Laufe von Generationen bloss durch die grössere Fruchtbarkeit entschieden wird, diese aber korrelativ durch geringfügige morphologische Unterschiede und unbedeutende Änderungen in der Lebensweise wesentlich beeinflusst werden kann. Durch die Mutationstheorie wird aber jene Schwierigkeit in keiner Weise gehoben, denn erstens stellen die Mutationen, wie auch Morgan zugibt, meistens geringfügige Abänderungen dar, welche die morphologische Breite der Fluktuationen nicht übertreffen. Man kann also nicht annehmen, dass das Stadium der Nützlichkeit mit einem Sprunge erreicht wird, dass etwa der Rollrüssel des Schmetterlings plötzlich aus kauenden Kiefern hervorging. Es mussten also eine Anzahl Mutationen in ganz bestimmter Weise aufeinander folgen, was, wie eben schon angedeutet wurde, nach unsern jetzigen Kenntnissen von diesen regelund richtungslosen Variationen unmöglich ist.

“2. Die neuen Mutationen können in zahlreichen Exemplaren auftreten und von ihren verschiedenen Sorten werden diejenigen sich erhalten, welche festen Fuss fassen können. Da dieselben Mutationen zu wiederholten malen auftreten können, wird die Gefahr, durch Kreuzung mit der Stammform vernichtet zu werden, im Verhältnis zu der Zahl der neu auftretenden Individuen geringer.' Dass eine neue Mutation bei ihrem ersten Auftreten sofort in zahlreichen Exemplaren erscheint, ist ein äusserst seltenes Vorkommnis. Mir ist aus der Literatur nur der eine Fall der Whiteschen WashingtonTomate bekannt, welche sofort zu I00\% aus der Varietät Acme zwei Jahre hintereinander auf derselben Lokalität entstanden sein soll. Die Mutationen der Gartenpflanzen sind alle von einer oder einigen wenigen Stammexemplaren ausgegangen, waren also extreme

*Plate, L., "Über die Bedeutung der Darwin'schen Selectionsprinzip," I903. 
Singularvariationen, und erst durch Isolation und Selbstbefruchtung hat man grössere Mengen von Individuen erzielt. Die zoologischen Mutationen weisen, soweit ihr Ursprung bekannt ist, immer auf ein Stammtier: so das I79I in Massachusetts entstandene Otterschaf, die $\mathbf{1 7 7 0}$ von einem hornlosen Stier ausgegangene Rinderasse in Paraguay und die Rasse der Mauchampschafe, welche 1828 zuerst in einem Lamm, das von Merino-Eltern abstammte, auftrat. Schwanzlose Katzen. Ziegen mit 4 Hörnern, Menschen mit 6 Fingern sind weitere Belege dafür, dass solche sprungartige Abänderungen grösste Seltenheiten sind. Da Selbstbefruchtung im Tierreich im allgemeinen als ausgeschlossen gelten kann, so können solche Fälle. nur durch grösste Inzucht und strengste Selektion zum Range einer Rasse erhoben werden. Correns,* der selbst grosse Verdienste um die Erkenntnis der Mutationen sich erworben hat, schreibt (S. 34) über die Notwendigkeit der Selbstbefruchtung: 'Es genügt aber nicht, die Samen einer neu entstandenen Form zu sammeln und auszusäen; es muss auch dafür Sorge getragen werden. dass diese Samen ausschliesslich durch Selbstbefruchtung entstehen oder wenigstens, wenn mehrere abgeänderte Individuen verwendbar sind, durch Inzucht. Bei der Bestäubung der abgeänderten neuen Pflanzen mit dem Pollen einer zur alten unverändert gebliebenen Form gehörenden Pflanze, die der Wind oder die Insekten ausführen können, entsteht ein Bastard zwischen der neuen und der alten Form, indem die letztere fast immer die erstere zunächst so vollkommen unterdrückt, dass der Bastard genau wie die alte Form aussieht. Die neue Form kann dann zwar in der folgenden Generation des Bastards wieder zum Vorschein kommen; in der Praxis beurteilt man aber die Erblichkeit nach der ersten Generation.' Wenn also in der freien Natur eine einzelne Mutation auftritt. so wird sie als Regel mit der Stammform sich kreuzen und Bastarde erzeugen, die entweder nach dem Mendelschen Gesetz wie die Stammform aussehen oder den neuen Charakter in abgeschwächtem Grade besitzen. Die meisten von diesen Bastarden werden sich wieder mit der unveränderten Stammform kreuzen, da deren Individuen weitaus in der Majorität sind, und so muss der neue Charakter in einigen Generationen wieder ausgelöscht werden, selbst wenn er in der ersten Zeit in einzelnen Individuen ab und zu zum Vorschein kommt. $\dagger$ Es gilt also meines Erachtens für die Mutationen dieselbe Regel wie für die Fluktuationen: Singular-

* Correns, C., "Experimentelle Untersuchungen über die Entstehung der Arten auf botan. Gebiet." Diese Zcitschr., I, I904, S. 27-52. Wie man sieht, vertritt Correns hier die Dominanz der phyletisch älteren Form.

$\dagger$ Vgl. hierzu S. 185, Anm. 
variationen spielen bei der Evolution keine Rolle, sondern nur Pluralvariationen, wenn wir absehen von jenen vereinzelten Fällen, in denen ein günstiger Zufall fur die Isolation der Singularvariation sorgt. Während aber bei den Fluktuationen sich leicht eine neue Rasse bilden kann, da immer viele Individuen nach dieser oder jener Richtung vom Durchschnitt abweichen oder durch die äusseren Faktoren in gleicher Weise verändert werden, liegen die Verhältnisse fur die Mutationen sehr viel ungünstiger.

"'3. Wenn die Zeit der Geschlechtsreife bei der neuen Form abweicht von der der Elternform, vermag sich die neue Ari nicht mit der Elternform zu kreuzen, und da dieser neue Charakter von Anfang an vorhanden ist, wird die neue Form bessere Aussichten haben am Leben zu bleiben als wenn der Zeitunterschied der Geschlechtsreife erst allmählich erworben werden müsste.' Morgan erwähnt hier eine ganz spezielle Form der sexuellen Isolation. Man braucht jedoch nicht anzunehmen, dass dieselbe von den Fluktuationen allmällich erworben wird; sie ist entweder von vornherein da, d. h. die neue Varietät wird in der Mehrzahl ihrer Individuen früher oder später geschlechtsreif als die Stammform, oder diese Schranke tritt überhaupt nicht auf. In diesem Punkte verhalten sich also die Fluktuationen genau so wie die Mutationen.

" 4. Die neuen Arten, welche erscheinen, können in einigen Fällen schon an eine andere Umgebung angepasst sein als die von der Stammform bewohnte; in diesem Falle werden sie von Anfang an isolirt sein, was einen Vorzug bei der Vermeidung der schlechten Einflüsse der Kreuzung bedeutet.' Auch diese biologische Isolation gilt natürlich in demselben Masse für die Fluktuationen. ja sie muss bei ihnen eine weit grössere Rolle spielen, denn nach der Darwin'schen Auffassung wandern gewisse Individuen allmählich in ein neues Wolngebiet ein und passen sich auf Grund ihrer Variabilität an dieses im Laufe von Generationen an. Wenn aber unter den Exemplaren einer in der Ebene lebenden Art plötzlich einige mutative Individuen auftreten, welche für das Leben im Gebirge eingerichtet sind, so ist gar nicht zul verstehen, wie solche Mutationen sofort die ihnen zusagende Wohnstätte resp. Lebensweise auffinden.

" '5. Es ist wohl bekannt, dass die Unterschiede verwandter Arten zum grossen Teile Differenzen unwichtiger Organe sind, und dies steht in Harmonie mit der Mutationstheorie, bildet aber eine der wirklichen Schwierigkeiten der Selektionstheorie.

" '6. Nutzlose oder selbst leicht schädliche Charaktere können als Mutationen auftreten und sich erhalten, wenn sie die Fortdauer der Rasse nicht ernstlich beeinflussen.'

"Morgan muss sich wirklich sehr wenig in die Darwinischen Gedanken eingearbeitet haben, wenn er nicht einsieht, dass die 
Selektionstheorie über den Ursprung der Variationen überhaupt nichts aussagt, sondern diese einfach als gegeben hinnimmt, mögen sie nur durch äussere Faktoren oder unbekannte innere Ursachen hervorgerufen werden und mögen sie nützlich, schädlich oder indifferent ausfallen. In dieser Hinsicht steht sie auf demselben Boden wie die Mutationstheorie, welche gleichfalls den Ursprung der Mutationen nicht aufklärt, sondern diese als plötzlich vorhanden ansieht. Die Selektionstheorie sucht uns nur klar zu machen, wie durch den Kampf ums Dasein die komplizirten nützlichen Einrichtungen, die Anpassungen, allmählich entstehen konnten, und da nahverwandte Arten häufig in dem Grade der Ausbildung solcher Anpassungen-man denke z. B. an die Unterschiede zwischen dem indischen und afrikanischen Elefanten im Bau der Rüsselspitze und der Ohren-voneinander abweichen, macht sie bis zu einem gewissen Grade auch den 'origin of species' verständlich.* Morgan wirft in seinem Buche immer und immer wieder ganz unberechtigter Weise dem Darwinismus vor, er behaupte 'That adaptations have arisen because of their usefulness.' Selbst die extremsten Anhänger Darwins haben immer nur gesagt: gewisse Variationen bleiben erhalten, weil sie nützlich sind, und indem eine nützliche Stufe zu der andern allmählich addirt wird, entstehen schliesslich jene auffallenden Einrichtungen, die wir 'Anpassungen' nennen. Genau denselben Standpunkt nimmt die Mutationstheorie ein. Auch für sie ist der Kampf ums Dasein-dieses Wort wie bei Darwin im weitesten Sinne genommen-das oberste regulatorische Prinzip der organischen Natur, welches die dauerfähigen Mutationen von den schädlichen sondert, dadurch die Evolutionen in ganz bestimmte Bahnen drängt und langsam die Entstehung der Anpassungen ermöglicht. Dadurch dass der Kampf ums Dasein das 'Uberleben des Passendsten' bedingt, schafft er etwas Positives und macht uns die mit dem Wechsel der Lebensweise und Umgebung stets wechselnden Formen der Anpassungen verständlich."

${ }^{28}$ Klebs, the eminent plant physiologist, keenly criticises the mutations theory in his paper on "Willkürliche Entwicklungsänderungen bei Pflanzen," 1903. See also Copeland, E. B., "The Variation of Some California Plants," Botan. Gaz., Vol. XXXVIII, pp. 40I-426, I904. In this paper the author describes some striking aberrant forms of oak and fern leaves, but shows that between these mutation-like forms and the modal forms intergrading steps exist. Copeland

* Es ist also nicht richtig, wenn Morgan (S. 454) von der Darwin'schen Theorie behauptet, sie werfe die Frage des Ursprungs der Arten zusammen mit der des Ursprungs der Anpassungen. Beide Probleme können zusammenfallen, aber sie brauchen es nicht. 
discusses keenly the mutations of de Vries and finds in them nothing radically different either in character or behaviour from the Darwinian fluctuating variations.

${ }^{27}$ Conklin, E. C., Science, N. S., Vol. XXI, p. 525, 1905.

${ }^{28}$ Morgan, "Evolution and Adaptation," p. 292, I903.

${ }^{28}$ Morgan, "Evolution and Adaptation," pp. 298-299. 1903.

References to ${ }^{30}$ Emery, C., "Gedanken zur Descendenz- und theories explain- Vererbungstheorie," Biolog. Centralblatt, Vol. XIV, ing secondary pp. 397-420, I893.

sexualcharacters. " ${ }^{31}$ Cunningham, J. T., "The Species, the Sex, and the Individual,' Natural Science, Vol. XIII, pp. I84-I92, 233-239, I 898.

${ }^{32}$ Wallace, A. R., "Tropical Nature," I878.

${ }^{33}$ Barrett-Hamilton, G. E. H., "Note on a Possible Mode of Origin of some Nuptial and Sexual Characters in Vertebrates," Anatom. Anzeig., Vol. XVIII, pp. 47-48, 1900. 


\section{CHAPTER XII.}

\section{DARWINISM'S PRESENT STANDING.}

A RIVER rises from a perennial spring on the mountain side; gravitation compels the water to keep moving, and rock

Natural selec- walls, intervening hills, and soft loam banks tion the final determine the course of the stream. The living
arbiter in descent. stream of descent finds its never-failing primal source in ever-appearing variations; the eternal flux of Nature, coupled with this inevitable primal variation, compels the stream to keep always in motion, and selection guides it along the ways of least resistance. Although there can be no modification, no evolution, without variation, yet neither can this variation, whatever its character and extent, whether slight and fluctuating, large and mutational, determinate or fortuitous, long compel descent to go contrary to adaptation. And the guardian of the course is natural selection. Selection will inexorably bar the forward movement, will certainly extinguish the direction of any orthogenetic process, Nägelian, Eimerian, or de Vriesian, which is not fit, that is, not adaptive. Darwinism, then, as the natural selection of the fit, the final arbiter in descent control, stands unscathed, clear and high above the obscuring cloud of battle. At least, so it seems to me. But Darwinism, as the all-sufficient or even most important causo-mechanical factor in species-forming and hence as the sufficient explanation of descent, is discredited and cast down. ${ }^{1}$ At least, again, so it seems to me. But Darwin himself claimed no Allmacht for selection. Darwin may well cry to be saved from his friends! 
The selection theories do not satisfy present-day biologists ${ }^{2}$ as efficient causal explanations of species-trans-

Natural formation. The fluctuating variations are not selection not a sufficient handles for natural selection; the satisfying explanation of speciesforming. hosts of trivial, indifferent species differences are not the result of an adaptively selecting agent. On the other hand the declarations of Korschinsky, Wolff, Driesch, and others that natural selection is nonexistent, is a vagary, a form of speech, or a negligible influence in descent, are unconvincing; they are unproved.

And these bitter antagonists of selection are especially unconvincing when they come to offer a replacing theory, an

The weakness of the replacing theories. alternative explanation of transformation and descent. To my mind every theory of heterogenesis, of orthogenesis, or of modification by the transmission of acquired characters, confesses itself ultimately subordinate to the natural selection theory. However independent of selection and Darwinism may be the beginnings of modification, the incipiency of new species and of new lines of descent; even, indeed, however necessary to natural selection some auxiliary or supporting theory to account for the beginnings of change confessedly is, the working factor or influence postulated by any such auxiliary theory soon finds its independence lost, its influence in evolution dominated and controlled by natural selection. As soon as the new modifications, the new species characters, the new lines of descent, if they may come so far, attain that degree of development where they have to submit to the test of utility, of fitness, just there they are practically delivered over to the tender mercies of selection. No orthogenetic line of descent can persist in a direction not adaptive, that is, not fit, and certainly no present-day biologist is ready to fall back on the long deserted standpoint of teleology and ascribe to heterogenesis or orthogenesis an auto-determination toward adaptiveness and 
fitness. Modification and development may have been proved to occur along determinate lines without the aid of natural selection. I believe they have. But such development cannot have an aim; it cannot be assumed to be directed toward advance; there is no independent progress upward, i. e., toward higher specialisation. At least, there is no scientific proof of any such capacity in organisms. Natural selection ${ }^{3}$ remains the one causo-mechanical explanation of the large and general progress toward fitness; the movement toward specialisation; that is, descent as we know it.

But what Darwinism does not do is to explain the beginnings of change, the modifications in indifferent characters An explanation and in indifferent directions. And all this is of the beginnings tremendously important, for there are among
of change is needed. animals and plants hosts of existent indifferent characters, and many apparently indifferent directions of specialisation. As to the obvious necessity of beginnings nothing need be said. What is needed, then, is a satisfactory explanation of the pre-useful and pre-hurtful stages in the modifications of organisms: an explanation to relieve Darwinism of its necessity of asking natural selection to find in the fluctuating individual variations a handle for its action; an explanation of how there ever comes to be a handle of advantage or disadvantage of life-and-deathdetermining degree. With such an explanation in our possession-and whether any one or more of the various. theories proposed to fill this need, such as Eimerian orthogenesis, de Vriesian heterogenesis, Rouxian battle of the parts, or Weismannian germinal selection, etc., give us this explanation, may be left for the moment undebated -with such a satisfactory explanation, I say, once in our hands, we may depend with confidence on natural selection to do the rest of the work called for by the great theory of descent. Among all the divergent lines of development 
and change, instituted by this agent of beginnings, natural selection will choose those to persist by saying No to those that may not. And the result is organic evolution.

But all this is equivalent to saying that there are other important factors in descent than selection, and that as to

The canses of the beginnings of descent-and this is speciesvariation and the forming-these other factors are the more immeans of segre- portant ones. Which I believe is true. The
gation, the chief factors in spe- causes of variation and the means of segregacies-forming. tion or isolation are the chief factors in actual species-forming. Certainly the mutations theory is not yet ready to offer itself as an explanation of adaptation, however confidently it may claim to be enrolled among speciesforming factors. The very same objections that have served to topple down selection from its high seat of honour, can be directed immediately and effectively against this latest claimant for recognition as the Great Cause of descent. Nor can geographical isolation explain modification where adaptation is included. Nor can Lamarck's beautiful explanation of adaptation claim validity, until the actuality of its fundamental postulate, the carrying over of ontogenic acquirements into phylogeny, be proved. And so with Buffon and St. Hilaire's influence of the ambient medium, and Eimer's modifying factors. Nor can any Nägelian automatic perfecting principle hold our suffrage for a moment unless we stand with theologists on the insecure basis of teleology.

No, let no ambitious student hesitate to take up the search for the truth about evolution from the notion that The unknown biology is a read book. The "Origin of Spefactors of evoln- cies" was the first opening of the book-that tion.

the world recognised at least; poor Lamarck opened the book but could not make the world read in itand that time when it shall be closed because read through is too far away even to speculate about. With Osborn " let us join the believers in the "unknown factors in evolution." 
Let us begin our motto with I gnoramus, but never follow it with Ignoribimus.

Now if we do not know, but want to know, and are willing to make an attempt toward knowing, where shall our energy

Prime needs of evolution study. of exploration and discovery be first directed?" To what particular points or aspects of the causes-of-evolution problem shall we give our first attention, what fields of study first invade? What, in a word, is the principal desideratum in present-day investigation of evolution? I should answer, the intensive study of variability. Not alone of the statics of variation but of its dynamics. Indeed, above all its dynamics. The experimental study of the stimuli, external and internal, the influences, extrinsic and intrinsic, which are the factors and causes of variation,- - this is the great desideratum; this the crying call to the evolution student. Experiment in variation study includes controlled modification of ontogeny (experimental development) and controlled modification of phylogeny (pedigreed breeding). In the study of variation statics, biometry is the greatest advance in modern methods, and the essential basis of biometric study, namely, quantitative and statistical data, must have its part in the investigation of variation dynamics. But in entering the realm of the causal study of variability, "we must not," as Roux has clearly pointed out, "conceal from ourselves the fact that the causal investigation of organism is one of the most difficult, if not the most difficult, problem which the human intellect has attempted to solve, and that this investigation, like every causal science, can never reach completeness, since every new cause ascertained only gives rise to fresh questions concerning the cause of this cause."

I believe that the neglect on the part of the selectionists to pay sufficient attention to the origin and causes of the variation which is such an indispensable basis of their theory, has been one of the most obvious reasons for the present strong 
reaction against the selection theories. Thankfully accepting the bricks and stones handed to them they have builded Neglect of a house of great beauty: but with stones of attention to the different shape a house of quite different ap-
causes of variation.

pearance might have been built. Is it not a cause for wonder that the selection masons have not been more inquisitive concerning the whence and why of this magical supply of just the needed sort of material at just the right time? As a matter of fact, Darwin himself gave serious attention to the origin of his always-ready variations, but his tremendous undertaking was too nearly superhuman already to permit him to add to it an adequate attention to the problem of causes. But that same excuse does not attach to his followers. And it is, I repeat, largely this neglect to strive to penetrate the so-far unrent veil of obscurity lying over the beginnings of species change that has contributed to the growing revolt against the Allmacht of the selection dogma. Who would in these days have a following for his explanation of species origin must include in his theory some fairly satisfying explanation of the first visible beginnings of modification.

Then, after the explanation of the why and how of variability, comes the necessity of explaining the cumulation of this variability along certain lines, the first visiHow is varia- ble issuance of these lines being as species, and tion cumulated? later becoming more and more pronounced as courses of descent. This explanation has got to begin lower down in phyletic history than natural selection can begin. Before ever there can be utility and advantage there must have come about a certain degree of heaping up, of cumulating, of intensifying variations. What are these factors? They are possibly only two: (I) orthogenetic or determinate variation as the outcome of plasm preformation or of epigenetic influences, and (2) the segregation of similar variations by physiologic or topographic conditions. Hence, 
next to the cause or origin of variability the great desideratum is a knowledge of the means of cumulating and directing variability. And both these great fundamental needs of a satisfactory understanding of organic evolution seem to me to be wholly unreferred to in the theory of natural selection. To be sure the control and cumulation of such large differences among organisms and species as are positively sufficient to determine the saving or the loss of life are explicable by selection. And this factor is sooner or later in any phyletic history bound to step in and probably be the dominant one. But a species, or a character, will always have a longer or shorter preselective existence and history, and it is precisely these days before the Inquisition of which we demand information. For of one thing we are now certain, and that is, that evolution and the origin of species have both their beginnings and a certain period of history before the day of the coming of the Grand Inquisitor, selection.

Finally there is still another desideratum and one whose seeking will carry us into dangerous country. For while there may be and are selectionists who might allow us to fumble about in the darkness of preselective time for first causes, there is probably none who will allow us to question his right to explain that other element in evolution besides species transformation, namely, adaptation, or, as the Germans untranslatably put it, Zweckmässigkeit. But by no means all biologists ${ }^{6}$ find in natural selection a sufficient explanation of adaptation.

In the visible expression of organic evolution are two chief elements, one the variety of life kinds, the existence of

The great noed of explain- other the adaptedness and adaptiveness of these ing adaptation. life kinds. The varieties of organic kinds show themselves adapted in structure and function to the varieties of environment and life-conditions. Hence, the task 
of an evolution explanation is a double one; it must explain not only diversity or variety in life, but adaptive diversity or variety. And there is no gainsaying to the selection explanation its claim to stand among all proposed explanations of adaptation as that one least shaken by the critical attack of its adversaries. However mightily the scientific imagination must exert itself to deliver certain difficult cases into the hands of selection, and however sophisticated and lawyer-like the argument from the selection side may be for any single refractory example, the fact remains that the selectionist seems to be able to stretch his explanation to fit all adaptations with less danger of finding it brought up against positive adverse facts than is possible to the champion of any other so far proposed explanation. The explanation of adaptation by natural selection steers wide of teleology on one hand and of unproved assumptions concerning heredity on the other. The protoplasmic consciousness of Cope and the automatic perfecting principle of Nägeli and those of his manner of explanation, are only indirect ways of attributing to natural forces visions and anticipations of what does not yet exist; while the influence of the ambient medium of St. Hilaire and of the extrinsic factors of Eimer, and the impressing photographically on the species and the carrying over into phylogeny, with approximate identity, of characteristics and modifications acquired ontogenetically by the individual as a result of functional stimulation-all these are assumptions not only apparently unproved, but in the light of our present knowledge of the mechanism of heredity seemingly unprovable.

Yet the explanation of species transformation and of adaptation by the introduction into phylogeny of modifications (reaction effects) arising in the individual during its ontogeny, has to its credit a certain logical proof, or basis, which has great validity in my mind, and yet which 
has enjoyed little general recognition and almost no emphasis from supporters of Lamarckism or neo-Lamarckism. As the great strength of the natural selection explanation of species-change and adaptation lies precisely in the logical nature of its premises and conclusions rather than on scientific observation and experiment, ${ }^{7}$ it certainly is not unfair to emphasise any similar kind of proof tending to support the Lamarckian type of explanation.

The logical proof that I refer to is simply this: It is a universally admitted fact that environment and functional

A logical proof stimulation can and do modify organisms durfor the introduc- ing their lifetime, and that this modification
tion into phylogein of adaptive is usually plainly adaptive. It is also an ontogenetic changes.

admitted fact that species differences or modifications are often identical with these cntogenetic modifications. That is, that under similar environment or life conditions species modification often follows the same lines as ontogenetic or individual modification. Now when we recall the possibilities of the hosts of ways in which the necessities of adaptation to varying environment might be met by selection among nearly infinite fortuitous variations, and yet see that exactly that means or line or kind of adaptive change occurs, which in the case of the individual is plainly and confessedly a direct personal adaptive reaction to varying enviromment, is it not the logical conclusion that the species change and adaptation is derived, not by the chance appearance of the needed variation, but by the compelled or determined appearance of this variation? In other words when species differences and adaptations are identical with differences and modifications readily directly producible in the individual by varying environment, are we not justified, on the basis of logical deduction, to assume the transmutation of ontogenetic acquirements into phyletic acquirements, even though we are as yet ignorant of the physico-chemical or vital mechanism capable of effecting the 
carrying over? Has natural selection's claimed capacity to effect species change, unseen by observer, untested by experimenter, any better or even other proof of actuality than that just offered on behalf of species modification as a direct result of the stimulus of varying environment and functional exercise? I cannot see that it has.

And this kind of argument, based half on observed facts and half on deduction, may be extended even farther on

The same kind behalf of the theory that species change is the of proof for non- direct reaction to envirommental conditions. adaptive change. For there are many ontogenetic variations produced directly in response to environment that are not plainly adaptive; many, indeed, between which and the environmental conditions that produce them no reasonable relation is apparent; no relation, that is, that would be exactly expected or could be foretold until empirically determined. In other words, many apparently non-significant ontogenetic differences or variations appear as direct result of environmental influence or stimulus. For example, individuals of certain species of the Crustacean phyllopod genus Artemia show marked structural differences when grown in sait water of varying density. These differences are in the size and shape of the plate-like lateral gills, the segmentation of the post-abdomen, the length of the caudal flaps (telson) and the hairiness of these flaps. The size of the whole body is also affected, individuals developing in water of higher density being markedly smaller than those which have been grown in less dense water. Now of all these differences only two seem to have what I call a reasonable relation to the environmental differences. The increased proportional size of the gills shown by the Artemias grown in denser water appears to be a regulatory change connected with the smaller amount of oxygen in the water, and the decreased size of the body may similarly be conceived by some to be an expected concomitant of the 
denser water condition. But what of the extra abdominal segment, the longer telson projections and their increased hairiness, all of which as shown by Schmankewitsch ${ }^{8}$ (however mistakenly this investigator may have interpreted his results as examples of actual species modification) and Anikin $^{2}$ for Artemia salina and by the writer ${ }^{10}$ for Artemia franciscanus, are the ontogenetic differences that varying density of salt water actually produces in individuals of a single Artemia species. These differences, these variations, are of the sort that I am calling non-significant, non-adaptive, non-reasonable. They would not be prophesied; they seem to have no reasonable correlation with the causes which produce them. But they are actually the results or effects of determined proximate causes which are extrinsic or environmental. If now the logical argument (based on identity of adaptive modification in individuals and in species) for the transmutation of ontogenetic changes into phyletic changes has any validity, then these non-adaptive, indifferent modifications may be transmuted as well as the adaptive ones, and thus hosts of trivial, non-adaptive indifferent species differences be explained on this LamarckoEimerian basis as well as the obviously adaptive modifications. But I am not insisting on this sort of argument too strongly. It is exactly the sort of argument upon which the theory of natural selection chiefly rests, and I have certainly tried to make evident in this book my belief in the danger of the substitution of this sort of logical or metaphysical basis of belief in a theory for a scientific basis of observation and experiment.

Finally, let us ask ourselves why we have adopted the common belief that our search for a cause of variability is a

A suggestion search for some so far unknown, some quite concerning the new factor or force in biology? May it not be canse of varia- that the factor is already familiar to us; so
tion. familiar indeed perhaps that we are esteeming it too simple 
and too obvious to play the rôle of the Great Desideratum, a causal factor of variability.

When one attempts to picture the process of the making of a new individual, and follows the complex phenomena of fecundation, of embryology, and post-embryonic development, is it not impossible to conceive of the production of two identical individuals? In all the course of this development, from the first cleavage of the fertilised egg-cell on, it is practically impossible to repeat processes absolutely identically, hence to produce absolutely identical organs, parts, cells. Now the germ-cells have their very origin in a repeated complex process, mitotic cell division; they are produced as nearly alike as possible, but it is not possible to make them absolutely identical.

Development, whether largely epigenetic or largely evolutionary, depends at least partly (probably largely) on the physical, i. e., structural, character of the germ-cells. Slight differences in the germ-cells then would lead to considerable differences in the fully developed organ. If the differences in the germ-cells happened, as would occasionally or rarely be the case, to be considerable, then the differences in the adults would be very considerable (mutations, sports, monsters, etc.). WVe know enough of the complex and epigenetic character of ontogeny to see plainly that identity among individuals, even of the same brood, is impossible.

Variation, then, seems the necessary, the absolutely unavoidable outcome of the conditions to which the developing individual is exposed. Indeed, all the individuals of a species might start (as fertilised eggs) exactly alike, and yet I cannot see how any two could come out alike. The inevitable slight differences in position, and hence in nutrition, in the results of the host of dividing and folding, invaginating and evaginating processes, the relations of each individual, whether in the mother's body or out of it, to everything else outside of itself-all these are conditions 
bound to vary a little between any two individuals. And as we know from the facts of experimental embryology that development is, partly at least, epigenetic in character, i.e., depends on and is influenced by external factors, this inevitable variation in influencing conditions is bound to produce variations in the individuals.

Is there, indeed, any need at all for assuming ( I) any mysterious "tendency" of the germ-plasm to vary? and (2) that the individual (continuous) variation depends wholly on germ-plasm structure? Why cannot the simple fluctuating or Darwinian variations be chiefly the result of the inevitable variation in the epigenetic factors, which, when not intruded on by exceptional disturbances, would themselves follow the "law of error" and hence produce "law of error" variability? All normal swingings of the variation pendulum in any part or character, between long and short, large and small, round and angular, smooth and rough, etc., etc., would result from the normal variation of the processes; the larger (extremes of range) variations being the fewer because the larger (extremes of range) variations in the ontogenetic processes would be the fewer. Exceptionally large epigenetic variations would produce exceptionally large variations in the individual-sports, mutations.

Klebs, ${ }^{11}$ as a result of his masterly experimental studies on modifications of plant development, comes to the conclusion that the only proved causes of variation are extrinsic influences stimulating, working through, or combined with, intrinsic conditions (not vitalistic, but physicochemical). Similarly, Tower, ${ }^{12}$ from his protracted studies on the variations in certain insects, concludes that all these variations are caused by external stimuli working on the germ-plasm.

If variation is thus simply the wholly natural and unavoidable effect $^{13}$ of this inevitable non-identity of vital process and environmental condition, why does not evolution 
possess in this state of affairs the much sought for, often postulated, all-necessary, automatic modifying principle an-

A determinate tedating and preceding selection which must though not pur- effect change, determinate though not purposeposeful change. ful? Nägeli's automatic perfecting principle is an impossibility to the thorough-going evolutionist seeking for a causo-mechanical explanation of change. But an automatic modifying principle which results in determinate or purposive change, that is, in the change needed as the indispensable basis for the upbuilding of the great fabric of species diversity and descent; is not that the very thing provided by the simple physical or mechanical impossibility of perfect identity between process and environment in the case of one individual and process and environment in the case of any other? It seems so to me.

But I do not know. Nor in the present-state of our knowledge does any one know, nor will any one know until, as Brooks ${ }^{14}$ says of another problem, we find out. We are ignorant; terribly, immensely ignorant. And our work is, to learn. To observe, to experiment, to tabulate, to induce, to deduce. Biology was never a clearer or more inviting field for fascinating, joyful, hopeful work. To question life by new methods, from new angles, on closer terms, under more precise conditions of control; this is the requirement and the opportunity of the biologist of to-day. May his generation hear some whisper from the Sphinx!

\section{APPENDIX.}

${ }^{1}$ One of the most serious and detailed critical analyses of the selection theory, resulting in conclusions totally antagonistic to Dar-

Wigand's criti- winism, is that of the Marburg botanist, Prof. Albert cism of the selec- Wigand, composing the three volumes entitled "Der tion theories. Darwinismus und die Naturforschung Newtons und Cuviers" (Vol. I, I874; Vol. II, I8;6; Vol. III, I877). From the "Announcements" at the beginning of each volume I quote as follows : 
From Vol. I. "Die hier dargebotene Kritik der Darwin'schen Lehre weist zunächst durch eingehende Prüfung der hierher gehörigen naturhistorischen Thatsachen nach, dass weder die Voraussetzungen, von denen die Theorie ausgeht, noch ihre Consequenzen mit der wirklichen Natur übereinstimmen, dass sie demnach den Anforderungen an eine wissenschaftliche Hypothese nicht entspricht. Vielmehr erweist sich dieselbe als eine philosophische Speculation, welche nicht nur die unserer Naturerkenntniss vorgezeichneten Grenzen überschreitet, sondern vor Allem die wichtigsten Grundsätze der wahren Forschung, wie sie durch die grossen Meister aufgestellt und in der bisherigen Entwickeiung der Naturwissenschaft allgemein anerkannt und unbedingt maassgebend gewesen sind, insbesondere die Principien der Causalität und der organischen Entwickelung, aufs grobste verleugnet. Demnach erkennt das vorliegende Werk seine Hauptaufgabe gerade darin, der bis dahin befolgten Forschungsweise gegenüber jener netuesten Naturphilosophie ihr Recht zu wahren."

From Vol. II. "Vermittelst der hierdurch gewonnenen Kriterien gelangt die Untersuchung in Betreff des Darwinismus zu folgendem Ergebnis: Derselbe geht nicht bloss von falschen Voraussetzungen aus, erweist sich nicht nur unfähig in Beziehung auf die versprochenen Leistungen, ist nicht nur verfehlt durch die principielle Unmöglichkeit seiner Aufgabe, ist nicht nur eine der Naturforschung fremdartige, rein speculative Operation, sondern indem derselbe das Princip der Causalität und Entwickelung mit dem Zufall und der Teleologie als Erklärungsgrunde vertauscht, erscheint er als eine der Naturforschung in ihrer Fundamentalmaxime widersprechende, darum dieselbe geradezu gefährdende Verirrung, um so mehr als er unter ihrer Maske auftritt. Der Darwinismus ist einer jener Versuche, welche im Namen der Naturforschung die Naturforschung verderben."

From Vol. III. "Der vorliegende dritte Band, mit welchem dieses Werk abschliesst, hat zum Gegenstand nicht die dem Darwinismus zu Grunde liegende Theorie, sondern die concrete Gestalt, in welcher derselbe als eine für unsere Zeit charakteristische culturhistorische Thatsache in die Erscheinung tritt. Insbesondere wird versucht, ein Bild von der Darwin'schen Schule als der Gesammtheit der die Transmutationstheorie vertretenden Auctoren und von der Art und Weise, wie sich die letztere im Lichte ihrer Bekenner darstellt, zu entwerfen. Hierbei ergibt sich, dass der Darwinismus mehr in einer ziellosen Zeitströmung und in einer wissenschaftlich nicht motivirten Stimmung der Geister als in einer bestimmt zu formulirenden Lehre besteht, und dass derselbe bereits in seinem eigenen Lager in allen wesentlichen Punkten wissenschaftlich überwunden ist, und zwar in solcher Weise, dass in den widerstreitenden Ansichten der Darwin- 
ianer doch zugleich der Keim für die allein richtige Auffassung der organischen Natur, wenn auch grossentheils unklar und unbewusst, verborgen liegt."

A special answer to this exhaustive pleading of Wigand is offered by H. Spitzer in his "Beiträge zur Descendenztheorie und zur Methodologie der Naturwissenschaft," I886.

${ }^{2}$ However, there still exist, especially in England, thoroughgoing Darwinians who see nothing serious in all this criticism of Lankester's their great compatriot's explanation of the origin of upholding of species. Lankester, one of the most prominent of Darwinism. English naturalists, said at York. last August (I906), in his inaugural address as president of the British Association for the Advancement of Science: "Under the title 'Darwinism' it is convenient to designate the various work of biologists tending to establish, develop or modify Mr. Darwin's great theory of the origin of species. In looking back over twenty-five years it seems to me that we must say that the conclusions of Darwin as to the origin of species by the survival of selected races in the struggle for existence are more firmly established than ever. And this because there have been many attempts to gravely tamper with essential parts of the fabric as he left it, and even to substitute conceptions for those which he endeavoured to establish, at variance with his conclusions. These attempts must, I think, be considered as having failed."

3 "Physiologic facts concerning the origin of species in nature were unknown in the time of Darwin. It was a happy idea to

De Vries's dis- choose the experience of the breeders in the produccussion of species- tion of new varieties, as a base on which to build an forming by explanation of the processes of nature. In my opinion selection.

Darwin was quite right, and he has succeeded in giving the desired proof. But the basis was a frail one, and would not stand too close an examination. Of this Darwin was always well aware. He has been prudent to the utmost, leaving many points undecided, and among them especially the range of validity of his several arguments. Unfortunately this prudence has not been adopted by his followers. Without sufficient warrant they have laid stress on one phase of the problem. quite overlooking the others. Wallace has even gone so far in his zeal and ardent veneration for Darwin, as to describe as Darwinism some things, which, in my opinion, had never been a part of Darwin's conceptions.

"The experience of the breeders was quite inadequate to the use which Darwin made of it. It was neither scientific, nor critically accurate. Laws of variation were barely conjectured; the different types of variability were only imperfectly distinguished. The breed- 
ers' conception was fairly sufficient for practical purposes, but science needed a clear understanding of the factors in the general process of variation. Repeatedly Darwin tried to formulate these causes, but the evidence available did not meet his requirements.

"Quetelet's law of variation had not yet been published. Mendel's claim of hereditary units, for the explanation of certain laws of hybrids discovered by him, was not yet made. The clear distinction between spontaneous and sudden changes. as compared with the ever-present fluctuating variations, is only of late coming into recognition by agriculturists. Innumerable minor points which go to elucidate the breeders' experience, were unknown in Darwin's time. No wonder that he made mistakes, and laid stress on modes of descent which have since been proved to be of minor importance or even of doubtful validity.

"Notwithstanding all these apparently unsurmountable difficulties, Darwin discovered the great principle which rules the evolution of organisms. It is the principle of natural selection. It is the sifting out of all organisms of minor worth through the struggle for life. It is only a sieve, and not a force of nature, no direct cause of improvement, as many of Darwin's adversaries, and unfortunately many of his followers also, have so often asserted. It is only a sieve, which decides which is to live, and what is to die. But evolutionary lines are of great length, and the evolution of a flower, or of an insectivorous plant is a way with many side-paths. It is the sieve that keeps evolution on the main line. killing all, or nearly all that try to go in other directions. By this means natural selection is the one directing cause of the broad lines of evolution.

"Of course, with the single steps of evolution it has nothing to do. Only after the step has been taken, the sieve acts, eliminating the unfit. The problem, as to how the individual steps are brought about, is quite another side of the question" (De Vries, "Species and Varieties," pp. 4-7, 1905).

The distinguished French zoölogist (Professor in the University of Paris), Delage, leader among French morphologists and experi-

Delage's esti- menters, voices his position concerning Darwinism in mate of selection, the following concise phrases ("L'Hérédité," $2 \mathrm{~d}$ ed., p. 397. 1903): "La sélection naturelle est un principe admirable et parfaitement juste. Tout le monde est d'accord aujourd'hui sur ce point. Mais où l'on n'est pas d'accord, c'est sur la limite de sa puissance et sur la question de savoir si elle peut engendrer des formes spécifiques nottvelles. Il semble bien demontrer aujourd'hui qu'elle ne le peut pas."

" "A study of the recent discussion in the Contemporary Rcview between Spencer and Weismann leads to the conclusion that neither 
of these acknowledged leaders of biological thought supports his position upon inductive evidence. Each displays his main force 0sborn's cham- in destructive criticism of his opponent; neither prepionship of the sents his case constructively in such a manner as to "unknown factors carry conviction either to his opponent or to others. In of evolution." short. beneath the surface of fine controversial style we discern these leaders respectively maintaining as finally established theories which are less grounded upon fact than upon the logical improbabilities of rival theories. Such a conclusion is deeply significant; to my mind it marks a turning point in the history of speculation, for certainly we shall not arrest research with any evolution factor grounded upon logic rather than upon inductive demonstration. A retrograde chapter in the history of science would open if we should do so and should accept as established laws which rest so largely upon negative reasoning. . . .

"The first step then towards progress is the straightforward confession of the limits of our knowledge and of our present failure to base either Lamarckism or neo-Darwinism as universal principles upon induction. The second is the recognition that all our thinking still centres around the five working hypotheses which have thus far been proposed; namely, those of Buffon, Lamarck, St. Hilaire, Darwin. and Nägeli. Modern criticism has highly differentiated, but not essentiaily altered these hypothetical factors since they were originally conceived. Darwin's 'survival of the fittest' we may alone regard as absolutely demonstrated as a real factor, without committing ourselves as to the 'origin of fitness.' The third step is to recognise that there may be an unknown factor or factors which will cause quite as great surprise as Darwin's." . .

"The general conclusion we reach from a survey of the whole field is, that for Buffon's and Lamarck's factors we have no theory of heredity, while the original Darwin factor, or neo-Darwinism, offers an inadequate explanation of evolution. If acquired variations are transmitted, there must be, therefore, some unknown principle in heredity; if they are not transmitted, there must be some unknown factor in evolution." (Osborn. H. F., "The Unknown Factors of Erolution." in Wood's Holl Biological Lectures, pp. 79, 80, 81, 98, and 99. I894.)

${ }^{3}$ Davenport, C. B., "Animal Morphology in its Relation to Other Sciences," Congress of Arts and Sciences, Vol. V, pp. 244-257, 1906. In this paper are pointed out in admirable manner the presentmoment problems, interests, and points of view of evolution biologists.

"Henry de Varigny, in "La Nature et La Vie." I905, says that for many adaptations "il n'y a pas à se dissimuler que, dans beaucoup 
de cas, cette explication [of the adaptation] est purement verbale; nous constatons un résultat. nous l'exprimons en essayant de l'interpréter; mais le mécanisme reste obscur. . . . Dans beaucoup de cas, l'adaptation est un phénomène que l'on constate sans peine mais qui dans l'état actuel de nos connaissances, reste sans explication" (p. 184 and p. 185).

Klebs, Georg. "Willkürliche Entwicklungsänderungen bei Pflanzen," 1903. An interesting, suggestive, and valuable account of

Klebs's concln- experiments, and their significance, on altering the sion from experi- developmental phenomena of plants. Although he is ments on plants. strongly opposed to any vitalistic theory which attributes to life an independence of physico-chemical laws, Klebs does not accept the Darwinian explanation of adaptiveness. Darwin "betrachtet die Zweckmässigkeit selbst als den wesentlichsten Faktor der Artbildung, indem nach seiner Meinung die natürliche Zuchtwahl aus der Menge der richtungslos auftretenden variationen nur die zweckmässigkeiten Merkmale zur Ausbildung und weiteren Entfaltung bringt. Daher stammt dic friiher so verbreitcte und heute uns sonderbar erscheinende Meinung, dass die Deutung eines Mcrkmales als eines zweckmässigen schon als eine Erklärung für scin Entstchen und scine Ausbildung angenommen zourde. Die Geltung der Darwin'schen Theorie muss seit den Arbeiten Nägelis, de Vries, u. a. jedenfalls eingeschränkt werden. Das eigentliche Problem der Artbildung muss, wie, wir später sehen werden in anderer Weise, formuliert werden" (p. 3).

Friedländer ("Entdeckung eines 'Atlantischen Palolo," etc., Biol. Centralbl., Vol. XXI, pp. 352-366, 1901) refers to the Darwinian explanation of Zucckmässigkcit as follows:

"Der ganze Darwinismus im weiteren, also auch vordarwin'schen Sinne der Descendenzhypothese, mit oder olne Betonung der SelekFriedländer's tionstheorie, und samt den allseitig als fertig und discussion of sichcr festgestellt gedachten Stammbäumen aller Oradaptation. ganismen, würde, wenn auch alles damit sonst seine Richtigkeit hätte, unsere Gesamterkenntnis keineswegs in so übermässigem Grade bereichern, wie man früher wähnte und vor allem nicht in dem Masse, als dass es sich lohnte, auf die Herstellung der zudem immer problematischen Stammbäume sonderliche Zeit und Mühe zu verwenden. Zweitens aber haben die neueren Experimentalforschungen Arten der Zweckmässigkeit an den Tag gebracht, welche aus rein logischen Gründen durch die Selektionstheorie durchaus nicht, auch nicht einmal scheinbar, 'erklärt' werden können. Nun ist aber doch gerade die vermeintliche 'Erklärung' der organischen Zweckmässigkeit oder sogen. 'Anpassungsvollkommenheit' die Hauptstärke des eigentlichen Darwinismus. Wie die Sache jetzt. 
liegt, müssten die Verteidiger des Darwinismus annehmen, dass die organische Zweckmässigkeit zwei vollkommen verschiedene Wurzeln habe. Die eine wäre die alte Darwin'sche oder darwinistischeda nämlich, wo diese logischerweise möglich ist; obwohl ja auch hier die Erklärung die nicht recht befriedigende Form hat, dass gesagt wird, die Zweckmässigkeit rühre daher, dass die weniger zweckmässigen Formen ausgestorben seien. Die zweite Wurzel der organischen Zweckmässigkeit, wie sie sich namentlich in den Selbstregulationserscheinungen äussert und zwar auch unter solchen Bedingungen, die in der freien Natur kaum jemals vorkommen und daher für das 'Bestehender Art' nicht von irgend welcher Bedeutung sein können-diese zweite Wurzel der Zweckmässigkeit ist der eigentliche Stein des Anstosses. Die Thatsachen sind hartnäckig, eine darwinistische Scheinerklärung ist hier unmöglich und die an sich doch so äusserst interessanten Erscheinungen, sowie die ganze experimentelle Forschungsmethode ist bei den eigentlichen Darwinisten nicht in gutem Ansehen; aus dem sehr begreiflichen Grunde, weil jene Thatsachen für die betreffende Richtung unbequem sind. Eine Reihe sicher festgestellter Thatsachen aus dem Gebiete der sogen. Selbstregulation beweist also, dass es organische $Z_{w e c k-}$ mässigkeiten und obendrein typische Beispiele von solchen giebt, welche dem Darwin'schen Erklärungsschema vollkommen trotzen. Nun aber hat die organische $Z$ weckmässigkeit im ganzen ein so einheitliches Gepräge, dass ein doppelter Ursprung von vorn herein äusserst unwahrscheinlich ist. Hieraus folgt dann weiter, dass die darwinistische Betrachtungsweise in der Wirklichkeit wahrscheinlich auch in den Fällen nicht zutrifft, wo sie logisch wenigstens die Möglichkeit einer Erklärung oder Quasierklärung darzubieten scheint. Endlich aber sollten auch diejenigen, denen die Bedenken gegen die darwinistischen Schlussfolgerungen nicht recht eingehen wollen, nachgerade doch wenigstens das einsehen, dass der Teil der Biologie, der sich allenfalls im darwinistischen Sinne behandeln liesse oder doch in Sinne jener Richtung nach Darwin'schen Prinzipien behandelt werden kann.-dass dieser Teil nur ein kleines und vergleichsweise auch unwichtiges Gebiet umfasst."

${ }^{7}$ Jacques Loeb, in a recent address ("Recent Development of Biology," Congress of Arts and Sciences, Vol. V. p. I7, 1906), takes this attitude toward the problem of species-forming: "The theory

Loeb's attitade of heredity of Mendel and de Vries is in full hartoward the prob- mony with the idea of evolution. The modern idea lem of species- of evolution originated, as is well known, with forming.

Lamarck, and it is the great merit of Darwin to have revived this idea. It is, however, remarkable that none of the Darwinian atthors seemed to consider it necessary that the trans- 
formation of species should be the object of direct observation. It is generally understood in the natural sciences either that direct observation should form the foundation of our conclusions or mathematical laws, which are derived from direct observations. This rule was evidently considered superfluous by those writing on the hypothesis of evolution. Their scientific conscience was quieted by the assumption that processes like that of evolution could not be directly observed, as they occurred too slowly, and that for this reason indirect observations must suffice. I believe that this lack of direct observation explains the polemical character of this literature, for wherever we can base our conclusions upon direct observations polemics become superfluous. It was, therefore, a decided progress when de Vries was able to show that the hereditary changes of forms, so-called 'mutations,' can be directly observed, at least in certain groups of organisms, and secondly, that these changes take place in harmony with the idea that for definite hereditary characteristics definite determinants, possibly in the form of chemical compounds, must be present in the sexual cells. It seems to me that the work of Mendel and de Vries and their successors marks the beginning of a real theory of heredity and evolution. If it is at all possible to produce new species artificially, I think that the discoveries of Mendel and de Vries must be the starting point."

${ }^{8}$ Schmankewitsch, A., Zeitschr. f. wiss. Zool., Vol. XXV, p. I03, I875; also Zeitschr. f. wiss. Zool., Vol. XXIX, p. 429, I877.

${ }^{\circ}$ Adelung, Zool-Centralbl., Vol. VI, p. 757, I899. (A review of Anikin's paper, which is in Russian.)

${ }^{10}$ Kellogg, V. L., "A New Artemia, and Its Life-Conditions," Science, N. S., Vol. XXIV, 594-596, 1906.

${ }^{11}$ Klebs, G., "Willkürliche Entwickelungsänderungen bei Pflanzen," I903.

${ }^{12}$ Tower, W. L., "Evolution in Chrysomelid Beetles of the Genus Leptinotarsa," Pub. No. 48, Carnegie Institution of Washington.

"The phenomenon of variation primarily owes its existence to the fact that community of descent and heredity tends to produce the exact counterpart of the parent organisms; the process of development, however, is not carried out under absolutely constant or uniform conditions, but in a world wherein there exist changing environmental states in endless proximity. This results in the turning aside in the line of development from the parental standard, perhaps ever so little or only in one character; but in this we have deviation or variation" (p. 298).

" "In the explanation of origin of variation in organisms the only assumption we need make is that the original unit of organic matter was possessed of the attributes which characterise organic matter 
to-day-motion, sensation, growth, and reproduction. This assumption cannot meet with any serious objection unless we change our ideas and definition of organic units. Granted the existence of one single organic unit endowed as above, there is no reason for introducing further complications by the explanation of phenomena through undemonstrable hypotheses, because the fact of variation in organic units can be explained solely through their existence in a natural world surrounded by varying conditions of existence" (p. 299).

"In the third chapter, where colour characters are used as subjects, it is demonstrated that variation is directly produced by stimuli-that from relatively invariable parents, stimuli produce variable offspring; and again in the fifth chapter it is shown that variations arise in direct response to stimuli" (p. 300).

"I maintain, therefore, that all organic variations are responsive to stimuli, and are not due to inherent tendencies or latencies, or the product of mystic elements" (p. 300).

${ }^{13}$ Montgomery, T. A., in a recent book of much interest ("Analysis of Racial Descent in Animals." 1906), explains clearly his belief in the inevitable production of variation (even that called blastogenic or congenital), and the influence on heredity (through this variation) by the influences of environment.

${ }^{14}$ Brooks, W. K., "The Foundations of Zoology." p. 43, I899. A most thoughtful and keen discussion of many of the conspicuous problems of "philosophical biology," written in lucid and epigrammatic style. In many ways Brooks stands at the head of American philosophical biologists. 



\section{INDEX.}

Adaptation, complex and correlated. not explicable by selection, I 44; Friedländer's discussion of. 392 ; lack of. in egg-laying habit of Phryganidia californica, 68 ; the great need of explaining, 380 ; not all explicable by Lamarckism, 272

Amphimixis, Weismann's principle of, I8o

Anosia, mimicry of, by Basilarchia, 49

Anti-Darwinism, present-day, 4

Baldwin. J. M., theory of orthoplasy, 208

Basilarchia, mimicry of Anosia by: 49

Bateson. W., records of discontinuous variation, 33 : suggestion that mutations are Mendelian recessives, $35 \mathrm{I}$

Battle of the parts, Roux's theory of, 20 I

Biologists, many not satisfied with the selection theory, 89

Biophor. 195

Brown-Séquard, experiments on guinea pigs, 290

Buffon, theory of ultimate structure of protoplasm, 216

Bumpus, H., example of increased variability due to emancipation from selection, 56; references to papers by, 69

Burbank, Luther, belief in Lamarckism, 272; scientific aspects of work of, 310

\section{Callosamia promethea, Mayer's} experiments with, I20

Carcinus, Weldon's selection experiments on, $\mathrm{I}_{5} 8$

Castle, WV. S., discussion of mutations theory, 364
Chance, law of, variation according to, 32-59

Characters, numerous, useful only in highly perfected state, 49 ; species, of no utility, 38

Colour and pattern of insects, Piepers' antagonism to selection explanation of, 69

Conn, H. W., discussion of the chances of death, 83 ; discussion of selective value, I82; statement of objection to selection, jased on trivial characters, 40

Cope, E. D., belief in orthogenetic evolution, 323; claiming that natural selection cannot make new characters, I85; theory of orthogenesis, 285

Correlation, references to papers on, I84

Crab, hermit and polyp, symbiosis of. 23

Crabs. Weldon's experiments on, I 58

Cunningham, J. T., criticism of Weldon's experiments on crabs, I6I ; discussion of orthogenesis, 326 ; experiments on flatfishes, 296; explanation of secondary sexual characters. 354 ; theory to explain secondary sexual differences, I24

Dall, IV., belief in sudden species-change, 330

Darwin. C., attitude toward determinate variation, 34 ; basis of theory of sexual selection, II2; explanation of descent, 13 ; on race origin from sports. 357 ; theory of sexual selection. III ; theory of ultimate structure of protoplasm, 2I8

Darwinism attacked, 25; attack on, by Dennert, 7; concilia- 
tory defence of, I64; death-bed of, I ; defended, I29; defined, 2 , IO; not synonymous with organic evolution. 2.3 ; present standing of, 374 ; upheld by Lankester, 389

Davenport, C. B.. discussion of mutations theory, 367

Death-bed of Darwinism, I

Death indiscriminate. So

Defence of Darwinism, I29

Degeneration, complete, not explicable by selection, 77 , I46; example of progressive, not explicable by natural selection, Ico: explanation of, by panmixia, I9o; Lamarchian explanation of, I92: Plate's Lamarckian explanation of, I47 ; Tayler's Darwinian explanation of, I47: Weismann's discussion of, 77

Delage, Y., criticism of Delbouf's law, 72 ; criticism of organic selection, 2Io; estimate of selection, 93, 390; macline theory of protoplasm, 225 ; theory of general variation, 289

Delbcuf's law, Delage's criticism of, 72

Dennert, E., attack on Darwinism, 7

Descent, Darwinian explanation of, I3; evidences for, I7; evidences of, references, 23; history of theory of, references. 22 ; natural selection the final arbiter in, 374 ; relations to theology, references, 23 ; theories of, I87; theory of, defined, II; theory of, distinguished from theory of natural selection, I 7 ; theory of, history, of. II ; theory, given validity by Darwin, I2; theory, relation to pedagogy, $2 \mathrm{I}$; theory, relation to sociology, $2 \mathrm{I}$; theory, relation to theology and philosophy, 20

Determinant, 95

DeVries, H., belief of, that artificial races are not fixed and constant forms, 87 ; discussion of geologic time and species-forming, 54; discussion of species-forming by selection, 389; objection to selection based on linear character of variation, I39; references to discussions of mutations theory by, 362 ; summing up of discussion of comparison of natural and artificial selection, 89; theory of mutations, 337 ; theory of the ultimate structure of protoplasm, 220

Dohrn, A., principle of change of function, I68

Douglass, N. G., observations on wall lizard, I23

Dürigen, observations on lizards, I 23

Eimer, Th., theory of orthogenesis. 282, $32 \mathrm{I}$

Emery, C., theory of primary variations, 332 ; theory of the origin of secondary sexual characters, 353 ; theory to explain secondary sexual differences, 124

Evolution, defined, Io: organic, not synonymous with Darwinism, 2. 3; Osborn's championship of the unknown factors of, 39I; the unknown factors of. 377

Evolution study, prime needs of, 378

Fischer, experiments with butterflies, 296

Fleischmann, A., opposed to evolution, 8

Friedländer, discussion of adaptation. 392

Friedman, H., theory of the convergence of organisms, 8

Galton, F., belief in heterogenesis, 332: discussion of specific stability, 359; discussion of variation according to the law of chance, 6r ; law of regression, 7I; statement of the law of regression, 97

Germ-cells, theories of ultimate composition of, 268 
Grinnell, Jos., study of geographic differences in the chickadee, 225

Gulick, J. T., studies of Hawaiian land snails, $25 \mathrm{I}$; theories of isolation influence, 249

Haacke, W., discussion of inheritance of acquired characters, 270 ; summary of Wagner's theory, 253

Haeckel, E., champion of evolution, I30

Hatschek, B., theory of the ultimate structure of protoplasm, 222

Henslow, G.. experiment of sowing of wheat, 80 ; references to books antagonistic to selection, 67

Heterogenesis, 326; belief in, of Dall, 330; Emery's theory of, 332: Korschinsky's theory of, 333 ; proposed by von Kölliker, 330

Hutton, F. W., argument for dualism, 23

Hyatt, A., experiments on Planorbis, 295

Inheritance of acquired characters, 263; Brown-Séquard's experiments, 290; Cunningham's experiments. 296; diffculties in accepting, 267; experiments with siikworms, 298: Fischer's experiments, 296: Haacke's discussion of, 270; Hyatt's experiments, 295; logical proof of. 382 ; Montgomery's explanation of, 306; references to discussions of, 305

Insects, parthenogenetical variation in, 58 ; variation in. 62

Interbreeding. swamping favourable variations, 44

Intra-selection, Roux's theory of, 20I ; Plate's criticism of Roux's theory of, 203

Isolation, biologic, 243; biologic, example of, 243; geographic, studied among past animals, $24 \mathrm{I}$; defined. 234; importance of, in species-forming, 232; not an all-sufficient agent of species-forming. 242; physiological, 245 ; references to discussions of, 253, 26I ; sexual, 245 ; theories. 232; various means of effecting, 234

Jaeckel, theory of metakinesis, 289

Johannsen, W., experiments with beans bred in pure lines, 72

Jordan, Karl, criticism of Vernon's theory of reproductive divergence. 249 ; on mechanical selection, 245

Jordan, D. S., on geographic isolation, 237

Kallima, case of, explained by Plate, I75; over-specialisation of, 53

Klebs, G., experiments on plants, 392

Korschinsky, $H_{\text {., }}$ radical antiselection position of, 9I ; theory of heterogenesis, 333

Kramer, P.. classification of secondary sexual characters, 107

Lamarck, references to his life and writings, 290

Lamarckism, 263; Burbank's belief in, 272; favoured by Redfield. 305; Plate's discussion of. 273; unable to explain all adaptations. 272; Weismann's attack on, 266

Lankester, R., answer to objection to selection, based on insufficient time, 55; upholding of Darwinism, 389

Law, Delbœuf's, Delage's criticisms of, 72 ; of chance, variation according to, 32, 59; of regression, Galton's, 7I; of regression, statement of Galton, 97

Le Dantec, F., chemical theorý of protoplasm, 225

Lizards, experiments on, I23

Loeb, J., attitude toward the problem of species-forming, 393 
Mallophaga, effects of isolation on, 240

Mayer, A. G., experiments on Promethea, I2I : experiments on sexual selection, I20

Mendei. G.. references to life and work. 356

Mendelism, references to discussions of, 357

Merriam, C. H., criticism of mutations theory, 367

Metakinesis, Jaeckel's theory of, 289

Mimicry of Anosia by Basilarchia, 49

Montgomery, Th., explanation of inheritance of acquired characters, 306

Morgan, C. L.. statement of conception of organic selection, 230: theory of orthoplasy, I45, 208: answer to objections to sexual selection theory, I49

Morgan. T. H. antagonism of species-forming by selection, 93: criticism of Weismann's method of argument, 229; discussion of de Vries's theory, 345: objections to sexual selection theory, is 8 ; summation of the advantages of the mutations theory. 350

Mutation, as used by Waagen, 324; de Vries's theory of, 337

Mutations theory, American opinion of. 362: attitude of naturalists toward, $3+8$; contrasted with Lamarchism, 349; contrasted with the isolation factor. 349; discussion of. by Castle. 364: discussion of, by Davenport, 366, 367; Merriam's criticism of, 367 ; Morgan's summation of the advantages of, 350; Plate's criticism of, 368; references to discussions of, by de Vries, 362

Nägeli, Ch., seven objections to species-forming by selection, 62 ; theory of orthogenesis, 277 ; theory of ultimate structure of protoplasm, 2 I9
Neo-Darwinians, concessions of, I 34

Neo-vitalism, 226

Organisms, number of living, Io Orthogenesis, 274; Cope's belief in, 323; Cope's theory of, 285 ; Cunningham's discussion of, 326; Eimer's theory of, 282, 320; Nägeli's theory of, 277; palæontologists in favour of, 288; Pfeffer's theory of, 320 ; Plate's résumé of evidence for, 279; Whitman's declaration in favour of, 288

Orthoplasy, 208; references to discussions of, 229

Orthoselection, contrasted with orthogenesis, 276

Osborn, H. F., championship of the unknown factors, of, 39I ; theory of orthoplasy, 208

Palæontologists favouring orthogenesis, 288

Panmixia, example of ineffective, 99; Weismann's theory of, I88: Wolff's criticism of, 98

Parallelism in variation, 279

Parthenogenesis, variation in insects produced by, 58

Pearson, K. discussion of variation according to the law of chance, 6I: theory of reproductive selection, 249

Pedagogy, relation of, to theory of descent, 2I

Pfeffer, G., objection to selection, based on the smallness of species-change. 75 ; statement of the fundamental difference between natural and artificial selection, 88 ; theory of orthogenesis. 320

Philosophy, relation to biology, references for, 24; relation to theory of descent. 20

Plrryganidia californica, lack of adaptation in egg-laying habit, 68

Piepers, M. C., antagonism to selection explanations of colour and pattern in insects, 69 
Plant-breeding, references for, I05

Plants, amelioration of, references for, 105

Plate, L., admission of the need of acquired characters to aid selection, I70, I78; answer to the claimed improbability of timely appearance of variations needed in co-adaptive structures, I76; answer to the objection concerning the dependence of selection on chance, I70; answer to the objection to selection based on the slightness of Darwinian variations, I65; claim that correlation may aid slight variation, I67; claim that same selective value may be obtained in different ways, I72; claim that selection works with plural variation, I72; classification of secondary sexual characters by, 107: conciliatory defence of Darwinism, I64; criticism of mutations theory, 368; criticism of organic selection, 210; criticism of Roux's theory of intra-selection, 203; discussion of Lamarckism, 273; disbelief in Weismann's principle of germinal selection, I80; explanation of character fixity in domestic animals, I63; explanation of the case of Kallima, 175; Lamarckian explanation of degeneration, I47 ; recognition of the weight of certain objections to Darwinism, I8I; résumé of facts tending to prove orthogenesis, 279; reviewer of criticisms of Darwinism, 30

Podocoryne and hermit crab, symbiosis of, 23

Polyp and hermit crab, symbiosis of 23

Promethea, Mayer's experiments on, I2I

Protoplasm, micromeric theories of structure of, 215; physical and chemical structure of, I94; theories of ultimate structure of, 2I4; Weis- mann's theory of the ultimate structure of, 195

Quetelet, discoverer of variation according to the law of chance, 6 I

Redfield, C., favouring Lamarckism, 305

Regression, Galton's law of, 7I ; statement of Galton's law of, 07

Romanes, G. J., discussion of Gulick's work and conclusions, 250; on physiological selection, 245

Rosa, D., theory of progressive reduction of variability, 322

Roux, W., theory of intraselection or battle of the parts, 201

Secondary sexual characters, Cunningham's explanation of, 354: Emery's theory of the origin of, 353; references to exposition of theories, 373; Wallace's suggested explanation of. 354

Seebohm's criticism of physiologic selection, 247

Selection, artificial, defined, I5; artificial, natural selection resting too largely on an analogy with, 85; based on variation, 30 ; cannot explain complete degeneration, 77; Coefficient, Wolff's discussion of, IOI; Darwin's theory of sexual, II I; Delage's estimate of, 390; de Vries's discussion of species-forming by, 389; de Vries's estimate of, 93; difficulty of explaining complex relations among body-parts by, 5I ; difficulty of explaining inter-species sterility by, 76 ; difficulty of explaining repeated identical structures by, 47 ; example of persistence of trivial differences in face of, I03; example of progressive degeneration, not explicable by, Ioo; final arbiter in descent, 374; geologic time too short to 
give it opportunity to do its work. 54; hindering rather than promoting species change, 56: Korschinsky's radical position against, 9I ; may produce continuous change, but not discontinuous series of species, 73: Morgan's antagonism of species-forming by, 93; natural, defined. I3; natural, needs sexual selection theory for support. I25; natural, rests too largely on analogy with artificial selection, I50; needs the support of the sexual selection theory, 85 ; not able to explain complex adaptation. I44; not able to explain degeneration, I46; not able to explain overspecialisation, I46; not able to produce many-branclied descent and discontinuity in series. I42; objection to, based on the linear and quantitative character of fluctuating variations, zo; objections to based on over-specialisation, 53 ; personal, how real, 82; Pfeffer's objection, based on the smallness of species change, 75 ; rests too largely on an analogy with artificial selection, 86; rigour of. questioned, I48; theories, Wigand's criticism of, 387 ; theory of, distinguished from theory of descent, I7

Selection, germinal, objection to theory of, 200 ; germinal, Weismann's theory of, I88, I93; germinal, resulting in determinate variation, 198

Selection, mechanical, 246

Selection, ontogenetic, 208

Selection, organic, 208; organic, Delage and Plate's criticisms of, 2 IO

Selection, physiological, criticisms of, 247

Selection, reproductive, Pearson's theory of, 249

Selection, sexual, ıо6, I20; alternative explanations of, I24; answers to objections to, I48; criticism of, by Wolff, G., I26; criticism of theory of, II3; Darwin's basis of theory, I I2; defined, I6; Morgan's objections to, II 8; other theories to replace theory of, I23; references to discussions of, I 25

Selectionists, concessions of, 90 Sexual differences, classification of secondary, I07; secondary, I06; significance of, I IO

Snodgrass. R. E., studies on bills of Galapagos birds, 323; studies on biologic selection, 245

Sociology, relations to biology, references for, 24 ; relation to theory of descent, 2 I

Species-forming, causes and means of segregation the chief factors in, 377: determinate variation as a factor, 33 ; de Vries's discussion of, by selection, 389; Loeb's attitude toward the problem of, 393; on a basis of fluctuating variation, 35; theories of, 187 ; Tower's experiments and conclusions, 309, 394

Spencer, H., example of the femur of the whale, 38 ; picture of the inutility of advantage in a single direction, 48 ; theory of ultimate structure of protoplasm, 2 I6

Sport in cattle, recent example of, $35^{8}$

Sterility, inter-species, difficulty of explaining by selection, 76

Struggle for existence, actual rigour of, 79 ; defined, I3

Symbiosis of hermit crab and polyp, 23

Tayler, J. L., answer to objection to selection based on linear variation, I4I ; Darwinian explanation of degeneration, I47; explanation of degeneration by natural selection, I62; general defence of natural selection, I53

Theology, relation of, to theory of descent, 20

Tower, W. L., experiments and 
conclusions on species-forming, 309, 394

Ultra-Darwinism, re a ction against, I 30

Utility, many species characters of no, 38

Variation according to the law of chance, 32, 59 : causes of, and means of segregation the chief factors in species-forming, 377; determinate. apparent cases of. 319; determinate, as a species-forming factor, 33; determinate, produced by germinal selection, I98; determinate, Whitman's belief in, 325; discontinuous, 33 . 328; favourable, swamped by inter-breeding, 44; fluctuating, as a basis for species-forming, 35; fluctuating, insignificance of, 36 ; fluctuating, of linear and quantitative value only. I39: fluctuating, too slight to be of selective value, I 38 ; general, Delage's theory of, 289; how cumulated. 379 ; in insects, 62; in parthenogenetic insects, 58; natural selection based on, 30 ; necessity for coincident appearance of other. to make a certain one effective, 46 ; non-correlated in bilaterally repeated organs, 65; occurrence of needed coincident, 45; orthogenetic, in palæontology, 319; parallelism in, 279; references for, 57; suggestion concerning the cause of, 384

Vejodovsky, example of progressive degeneration not explicable by natural selection, 100

Vernon, H. M., theory of reproductive divergence, 248 ; theory of the ultimate structure of protoplasm, 225

Vestigial structures, explanation of, by panmixia. I90; Lamarckian explanation of, 192

Von Kölliker, R., proposal of a theory of heterogenesis, 330

Waagen, use of term mutation, 324

Wagner, M., formulation of Separations-theorie, 236; founder of theory of speciesforming by geographic isolation, 234

Wallace. A. R., criticism of Romanes's theory. 247; suggested explanation of secondary sextral characters. 354

Weismann. A., adninission of objections to selection, 45: attack on Lamarckism1. 266; discussion of degeneration, 77; principle of amphimixis. I80: references to evolution writings of, 2I2; theory of germinal selection. I88. I93: theories of neo-Darwinism and neoLamarckism. I33; theory of panmixia. I88

Weldon, selection experiments on Carcinus. I58

Whitman. C. O.. belief in determinate variation. 325; favouring orthogenesis, 288

Wolff, G., attack on the assumption by selectionists of the appearance at the right time of the needed variation, 64; criticism of panmixia by 98; criticism of sexual selection, I26: discussion of selection. coefficient. IOI : objections to explanation by selection of complex related body-parts. 5I ; objection to natural selection. based upon its dependence on sexual selection theory, I25; objections to sexual selection theory, I26; objection that selection can concern only quantitative changes. $70: \quad \mathrm{ob}-$ jection to the assumption by selectionists of identical and coincident variation. 67 




\section{AMERICAN INSECTS}

BY VERNON L. KELLOGG

PROFESSOR IN LELAND STANFORD, JR., UNIVERSITY

W

I'TH 812 figures and I colored plates: $647 \mathrm{pp}$. (American Nature Series, Group I); \$5.00 net (postage 34 cents). Students' edition, $\$ 4.00$. A comprehensive account of the natural history of the insects of America, written simply yet seriously, so as to be acceptable to the general reading public as well as to professional students of nature. All of the insect orders represented in onr country are treated in this single volume, which, despite its comprehensiveness and its profusion of illustrations, is so compactly made as to be in no way unwieldy. The book may be used for continuous reading by those wishing to inform themselves concerning the kinds and habits of American insects in general, or as a reference manual for authoritative information on classification, specific remedies for certain pests, special discussions of structural, physiological, or ecological phases of insect biology, etc.

"Certain to be widely useful . . readable and profusely illustrated. It gives a great amount of information about the insects of this country, in such a manner that it is available to any intelligent person... other works are necessary for particular purposes; but if $I$ were asked to name a single work for a beginner, who at the same time meant business, I should not hesitate to recommend this new product of Stanford University." $-7: D . A$. Cockerell in The Dial.

"Nothing needed to make this a complete guide to the study of our American insects has been omitted." -11 . A. Bigelow in the Independent.

"Professor Kellogg's volume will be welcomed as one of the best general text-books on the subject covered."-C. L. Marlatt in Science.

"The work is scientifically conceived and carefully executed in every part: but it is free from all unnecessary technicalities and so fresh in its spirit and so informal in its tone that one scarcely remembers in reading it the scientific attainments of its eminent author. It is a storehouse of biological information drawn from authoritative sources and vivified by contributions from the author's own rich experience as an observer and an investigator. . . The style is vivacious, flowing, correct, as pellucid as a mountain brook, and free from all those affectations of sprightliness or sentiment which seem likely to become conven. tional in the literature of nature study."-S. A. Forbes in School Science.

"An excellent work, and we can heartily recommend it to al" who are interested in the classification and natural history of insects. It is written in an agreeable and attractive style and can be referred to anywhere by the ordinary reader without fear of being disheartened by purely technical language ... the greater 
part of the large volume is clear and simple and most interesting to every Nature Student. . . No one can take up the book and open it any where without becoming deeply interested in the subject treated of, whatever it may be, provided, that is, that he has any love at all for living creatures, any interest in the myriad forms and modes of life of these wonderful beings that are every where about us." - Canadian Entomologist.

"Sumptuous, delicate, exquisite, these are the words that easily leap to our lips in looking through the book. But I cannot too much emphasize the fact that in the volume we also have science made thorouglily readable." -E. P. Powell in Unity.

"Is probably the most valuable handbook of the subject for the technical student or amateur collector." - Kansas Farmer.

"Ein ebenso reichhaltiges wie luxuriös ausgestattetes Werk zur Einführung in das studium der Biologie der amerikanischen Insekten." - Edin. Reitter in Wiener Ent. Zeitung.

"The book is of the first importance in its class."-Out H'est.

"This work easily ranks as the most comprehensive volume treating of American insects yet produced... The subjectmatter is presented in an easy narrative style, though accuracy is not sacrificed for the sake of popularity. ... The volume exhibits a thorough appreciation of and familiarity with recent investigations. . . This work brings together in one volume a vast amount of information and the author is to be congratulated upon having produced a very readable, comprehensive work, which should prove attractive and exceedingly helpful to the amateur as well as essential to every investigator." $-E$. P. Felt in Psyche.

"We have in this single volume a whole library of insect lore." $-N$. I. Critic.

"Es ist ein gewaltiges Unternehmen, das Verf. in diesem Werke zur Durchführung gebracht hat und die vollendete Art und Weise dieser Durchführung dürfte dem Buche in seinem Vaterlande einen vollen Erfolg sichern. Es will seinen Lesern eine Lebersicht über die gesammte Insekten welt geben, aber nicht in dem oberflächlichen Feuilletonstil, den man in derartigen Werken häufig findet, sondern mit wirklichen wissenschaftlicher Gründlichkeit, und das ist dem Verfasser vorzüglich gelungen." -Zeitschr. fïr wissenschaftlche Insektenbrologie.

"The work is probably the best that exists for anyone desiring an introductory work on North American insects compressed into a single volume." - David Sharp in Nature.

"We are glad to see the interesting chapter on insects and disease, as it places the subject on a higher plane with the general public, and is a matter of immense importance to humanity. 'Taking the worli in its entirety it is a valuable contribution to the subject, and can't fail to be useful to the student beginner as well as to entomologists in general." -Entomological $\Lambda$ ews.

"To many readers, especially to those who, whilst studying specially one order, want a clear explanation of the general character and biology of the other orders, the book must be a precious boon, from which the fact that the illustrations are taken from American insects detracts nothing. Dr. Kellogg has long undoubtedly been in the first rank of American entomologists, and this latest work can only add lustre to an already distinguished name." $-J$. W. Tutt in Entomologist's Record (London).

\section{HENRY HOLT AND COMPANY}

\section{Publishers}

NEW YORK 




18 t9

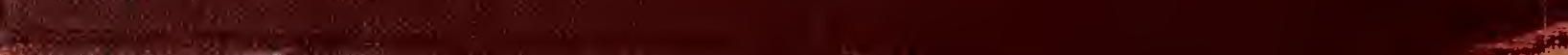

